UNIVERSIDADE DE SÃO PAULO

INSTITUTO DE GEOCIENCIAS

\title{
EFEITOS DA URBANIZAÇÃO SOBRE O SISTEMA HIDROLÓGICO: ASPECTOS DA RECARGA NO AQÜÍFERO FREÁTICO E ESCOAMENTO SUPERFICIAL - ÁREA PILOTO: SUB-BACIAS SUMARÉ E POMPÉIA, MUNICÍPIO DE SÃO PAULO
}

Leila Nunes Menegasse Velásquez

Orientador: Prof. Dr. Uriel Duarte

\section{TESE DE DOUTORAMENTO}

Programa de Pós-Graduação em Recursos Minerais e Hidrogeologia

\author{
SÃo PAULO \\ 1996
}


UNIVERSIDADE DE SĀO PAULO

INSTITUTO DE GEOCIENCIAS

\section{EFEITOS DA URBANIZAÇĀO SOBRE O SISTEMA HIDROLÓGICO: ASPECTOS DA RECARGA NO AQÜÍFERO FREÁTICO E ESCOAMENTO SUPERFICIAL - ÁREA PILOTO: SUB-BACIAS SUMARÉ E POMPÉIA, MUNICÍPIO DE SĀO PAULO}

Leila Nunes Menegasse Velásquez

Orientador: Prof. Dr. Uriel Duarte

TESE DE DOUTORAMENTO

COMISSÃO JULGADORA

nome

Presidente :

Examinadores:

\begin{tabular}{l} 
Uriel Duarte \\
Alberto Pacheco \\
\hline Claudio Riccomini \\
Adelbani Braz da Silva \\
\hline Ruben La Laina Porto
\end{tabular}

ass.

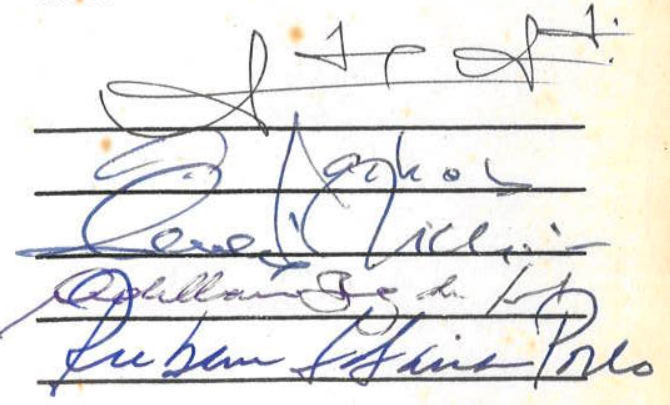




\section{UNIVERSIDADE DE SÃO PAULO INSTITUTO DE GEOCIENCIAS}

\section{EFEITOS DA URBANIZAÇĀO SOBRE O SISTEMA HIDROLÓGICO: ASPECTOS DA RECARGA NO AQÜÍFERO FREÁTICO E ESCOAMENTO SUPERFICIAL - ÁREA PILOTO: SUB-BACIAS SUMARÉ E POMPÉIA, MUNICÍPIO DE SÃO PAULO}

Leila Nunes Menegasse Velásquez

Orientador: Prof. Dr. Uriel Duarte

TESE DE DOUTORAMENTO

Programa de Pós-Graduação em Recursos Minerais e Hidrogeologia
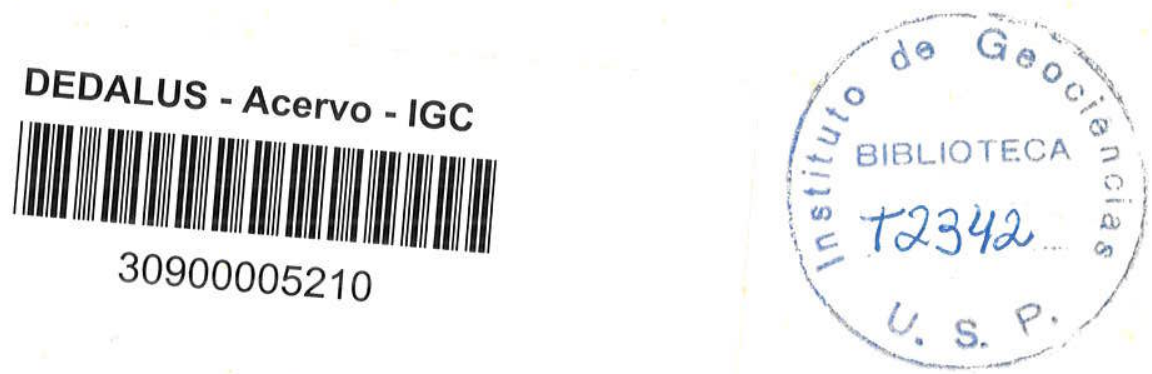
Dedico este trabalho a meu filho Diego e a meu marido Gustavo. 


\section{AGRADECIMENTOS}

Gostaria de prestar meus sinceros agradecimentos:

Ao Instituto de Geociências, na pessoa do Prof. Dir. Adilson Carvalho, Diretor, pela oportunidade de realização da pesquisa. neste Instituto.

A Fundação de Amparo à Pesquisa no Estado de São Paulo, FAPESP, pelo financiamento do projeto.

À Coordenadoria de Aperfeiçoamento para Ensino Superior (CAPES) e ao Conselho Nacional de Pesquisa (CNPQ), órgãos financiadores da bolsa pesquisa.

Ao Centro de Pesquisas de Águas Subterrâneas (CEPAS-IG/USP), na pessoa do Diretor Prof. Dr. José Milton Benetti Mendes, pelo suporte técnico na realização das atividades de campo e análises químicas das águas.

Ao Professor Dr.Uriel Duarte, meu orientador, pelo apoio, incentivo, confiança e orientação prestada.

Ao meu companheiro Jorge Gustavo Velásquez pelo incentivo, apoio e auxilio demonstrados.

Aos colegas, Paulo Ricardo Brum Pereira e Hélio Nóbili Diniz pelo apoio e discussões.

Ao inestimável colega Gildo Mistreta pelo apoio, revisão crítica da tese.

Aos colegas do Instituto de Pesquisas Tecnológicas (IPT), Samuel e Mário pelo apoio em campo e laboratório de solos; e Cláudio, pelas valiosas horas dedicadas a discussões.

A Elaine, técnica do laboratório de solos do Departamento de Paleontologia e Estratigrafia (DPE/IG-USP), pelo apoio na análise granulométrica, e à aluna de graduação Eliana pelas análises realizadas.

Ao Engenheiro José Carlos Pallos, do DAEE/CTH pelas discussões temáticas.

Ao Senhor Antônio Alves, ex-funcionário do CEPAS, pelo perfuração dos poços de monitoramento e apoio durante a fase de monitoramento.

Aos Engenheiros Denise Hellu e Nelson Victor, ambos meus superiores na Prefeitura do Município de São Paulo, pelo grande apoio e incentivo prestados.

Aos bolsistas de iniciação científica, Mário e Flávio pela elaboração dos mapas.

A Escola Muncipal de Educação Infantil (EMEI) Santos Dumont e Nacional Atlético Clube pela autorização para perfuração de poços nos seus terrenos.

Ao corpo de funcionários, professores, especialmente à Profa. Aurélia Kimmeimann, e a todos os colegas do Departamento de Geologia Econômica, que de alguma forma contribuiram para realização desta pesquisa, 
INTRODUCÃO $l$

OBJETIVOS 2

1. GENERALIDADES 2

1.1 APRESENTAÇÃO DA ÁREA DE ESTUDOS 2

1.2 JUSTIFICATIVAS PARA A REALIZAÇÃO DO ESTUDO E ESCOLHA DA ÁREA 4 2. FUNDAMENTAÇÃO TEÓRICA: CONCEITOS, ASPECTOS METODOLÓGICOS E ESTUDOS INVESTIGADOS NA LITERATURA 7

2.1. FATORES QUE INFLUEM NA RECARGA AQÚÍFERA E NO ESCOAMENTO _ 10 SUPERFICIAL 10

2.1.1. Recarga 10

2.1.2. Escoamento superficial direto 10

2.2 MÉTODOS DE ESTIMATIVA DA RECARGA 11

2.2.1 Fatores que influenciam a escolha do método 13

2.2.1.1 Processos de recarga 14

2.2.1.2 Objetivos do Estudo 15

2.2.2 Métodos de estimativa de recarga aplicados em áreas urbanas 16

2.2.3 Exemplos de estudos realizados 18

2.2.4 Estudos desenvolvidos na Bacia Sedimentar de São Paulo 19

\subsection{MÉTODOS APLICADOS À ANÁLISE DO ESCOAMÉNTO SUPERFICIAL} URBANO 21

2.3.1 Medidas alternativas para o controle de enchentes 22

3. QUADRO GEOLÓGICO E HIDROGEOLÓGICO REGIONAL 25

3.1 CONTEXTO GEOLÓGICO-TECTÔNICO 25

3.2 A BACIA SEDIMENTAR DE SÃO PAULO 25

3.2.1 Embasamento Pré-cambriano 27 
3.2.2 Sedimentos Terciários 27

3.2.2.1 Formação Resende 27

3.2.2.2 Formação São Paulo 28

3.2.2.3 Formação Itaquaquecetuba 28

3.2.3 Coberturas Cenozóicas 29

\subsection{CONTEXTO HIDROGEOLÓGICO} 29

3.3.1. Sistema Cristalino 30

3.3.2. Sistema Sedimentar 31

4. MATERLAIS E MÉTODOS 33

4.1. LEVANTAMENTOS DE DADOS 33

4.1.1 Bibliografia 33

4.1.2 Infraestrutura da área 33

4.1.3 Perdas na rede de distribuição de água 33

4.1.4 Nascentes 33

4.1.5 Poços profundos 34

4.1.6 Sondagens "SPT" 34

4.1.7 Dados meteorológicos 34

4.2. ATIVIDADES DE CAMPO 34

4.2.1 Construção dos poços de monitoramento 34

4.2.2 Coleta de amostras de solo para caracterização granulométrica 36

4.2.3 Execução dos Ensaios de Permeabilidade in situ 36

4.2.4 Coleta de amostras indeformadas para ensaio da porosidade efetiva 37

4.2.5 Monitoramento em poços e nascentes 37

4.2.6 Amostragem da água 38

\subsection{ATIVIDADES DE LABORATÓRIO} 38

4.3.1 Análise química das águas dos poços e das nascentes 38

4.3.2 Ensaio granulométrico do solo 38

4.3.3 Ensaio da porosidade efetiva 39

4.3.4 Estimativa da área impermeável 39

4.3.5 O Balanço Hídrico Climatológico 40

5. CARACTERIZAÇAOO DA ÁREA DE ESTUDO 
5.2 CLIMA 44

5.3 GEOLOGIA 45

\subsection{HIDROGEOLOGIA} 59

5.4.1 Caracterização geral dos aqüíferos 49

5.4.2 Potencialidades hídricas 52

5.4.3 A zona não-aturada 54

6. ESTUDO DA RECARGA AQÜÍFERA 57

\subsection{ANÁlISE PRELIMINAR DOS COMPONENTES DO SISTEMA} HIDROLÓGICO 57

6.1.1 Precipitação 57

6.1.2 Comportamento das nascentes 58

6.1.3 Comportamento do nível freático 61

6.1.4 Velocidade de infiltração vertical 63

6.1.5 Estimativa da área impermeável 68

6.1.5.1 Terreno terciário 70

6.1.5.2 Terreno quaternário 72

\subsection{ESTUDO DA RECARGA DIRETA} 73

6.2.1 Aqüífero terciário 75

6.2.2 Aqüífero quaternário 77

\subsection{AVALIAÇĀO DOS EFEITOS DA IMPERMEABLLZAÇÃO SOBRE A} RECARGA 83

6.5.1 O Balanço hídrico climático 83

6.5.1.1 Situação de pré-ocupação da bacia 84

6.5.1.2 Situação de pós-ocupação da bacia 88 


\subsection{CARACTERIZAÇÃO QUIMMICA DAS ÁGUAS DO AQÜÍFERO}

FREÁTICO

7. ESCOAMENTO SUPERFICIAL 96

7.1 CONSIDERAÇÕES 96

7.2 A LEI MUNICIPAL 97

7.2.1 histórico 97

7.2.1.1 Interpretação da lei 98

7.3 ESCOAMENTO SUPERFICIAL DIRETO 99

7.3.1 Parâmetros das sub-bacias 102

7.3.2 Caracteríticas da ocupação 103

7.3.3 Capacidade dos reservatórios de retenção do escoamento na bacia 105

7.3.4 Resultados 106

7.3.4.1 Análise dos resultados 107

8. DISCUSSÃO 108

9. CONCLUSÕES 112

10. REFERÊNCIAS BIBLIOGRÁFICAS 114

ANEXOS 


\section{LISTA DE FIGURAS}

Página

FIGURA I - Mapa de localização da área 3

FIGURA 2 - Mapa do sistema viário e bairros 6

FIGURA 3 - Principais componentes do sistema hidrológico urbano (LERNER, 1990) 8

FIGURA 4 - Escalas de tempo para estimativa darecarga direta (LERNER, 1987) 15

FIGURA 5 - Mapa geológico simplificado da Região Metropolitana de São Paulo (In:

Mori, 1992) 15

FIGURA 6 - Fisiografia e pontos d'água 41

FIGURA 7 - Pluviometria mensal plurianual do Posto Pluviométrico

"Lapa" 44

FIGURA 8 - Mapa Geológico 45

FIGURA 9 - Superficie Potenciométrica 49

FIGURA 10 - Isoprofundidade do nivel d'água 51

FIGURA 11 - Valores típicos de permeabilidades de diferentes tipos de solos (adaptado de Bowles, 1984 e Walton, 1988) 56

FIGURA 12 - Precipitacão mensal plurianual (1980 a 1992) e mensal (1994/1995)_..58

FIGURA 13 - Precipitação e vazão das nascentes 61

FIGURA 14 - Zoneamento urbano 69

FIGURA 15 - Curva de Retenção e porosidade efetiva 76

FIGURA 16 - Precipitação e recarga nos domínios Terciário e Quaternário 79

FIGURA 17 - Setores de abastecimento - SABESP 82

FIGURA 18 - Balanço hídrico climático 86

FIGURA 19 - Relação entre os componentes do Balanço Hidrico na situação de préocupação da bacia (Valores em relação à precipitação nual)

FIGURA 20 - Relação entre os componentes do Balanço Hidrico na bacia urbanizada (Valores em relação à precipitção anual) 91

FIGURA 21 - Variações do pH - Poços de Monitoramento 93

FIGURA 22 - Variações do pH - Nascentes 93

FIGURA 23 - Variações da Condutividade Elétrica - Poços de Monitoramento 95 


\section{LISTA DE TABELAS}

Página

TABELA I - Granulometria dos materiais constituintes do terreno terciário 48

TABELA 2 - Cadastro dos poços profundos 53

TABELA 3 - Parâmetros hidrodinâmicos dos poços 54

TABELA 4 - Resultado dos Ensaios de Permeabilidade 55

TABELA 5 - Volumes precipitados na área 58

TABELA 6 - Vazões das nascentes 59

TABELA 7 - Identificação e Localização dos Poços de Monitoramento 62

TABELA 8 - Correlação entre a profundidade do nível d'água e precipitação mensal63 TABELA 9 - Velocidade média de infiltação e tempo de resposta (medições quinzenais e mensais) 65

TABELA 10 - Coeficientes de correlação entre a precipitação e profundidade do nível d'água (medições de 4 em 4 dias) 66

TABELA 11 - Velocidade de infiltração e tempo de resposta (medições de $4 \mathrm{em}$ 4 dias) 67

TABELA 12 - Parâmetros para a estimativa da taxa impermeável das áreas amostradas nas zonas $Z_{l}, Z_{2} Z_{3} e$ 70

TABELA 13 - Parâmetros para o cálculo estimativo da taxa de construção média 71

TABELA 14 - Recargas diretas mensais no aqüifero terciário 77

TABELA 15 - Recargas diretas mensais no terreno quaternário 78

TABELA 16 - Distribuição mensal da recarga nos aqüiferos terciário e quaternário_79

TABELA 17 - Parâmetros do cálculo das perdas físicas na área de estudos no periodo de out/1994 a set/1995 83

TABELA 18 - Balanço Hídrico 85

TABELA 19 - Evapotranspiracão Potencial a partir de medidas de evaporação medidos em tanque classe A. (Fator de conversão: ,80) 87 
TABELA 20 - Balanço das entradas e saídas dos recursos do sistema hidrológico atual 90

TABELA 21 - Capacidade dos micro-reservatórios 105

TABELA 22 - Parâmetros hidrológicos calculados pelo método de Horton 106

TABELA 23 - Parâmetros hidrológicos obtidos pelo método de Santa Bárbara 107

\section{LISTA DE QUADROS}

Página

QUADRO 1 - Distribuição dos índices de ocupação por tipo de uso 74

QUADRO 2 - Perdas de água, segundo as origens, para a RMSP (SABESP) 80 QUADRO 3 - Perdas por Armazenamento em Depressões e por Detenção (CUHP) 89 QUADRO 4 - Correspondência entre os parâmetros de Horton e o tipo hidrológico do solo (PORTO, 1995) 100 


\section{LISTA DE ANEXOS}

ANEXO 1: Perfis litológicos: Poços de monitoramento I a 13, Figuras 1 a 13 , respectivamente.

ANEXO 2: Gráficos: Curvas granulométricas dos solos amostrados nos poços de monitoramento $3,5,6,8,9,10,12$ e 13. Figuras 1 a 8 respectivamente.

ANEXO 3: Planilhas de campo: Precipitação - oscilação do nível freático nos poços de monitoramento $1,2,3,4,5,6,7,8,9,10,11,12,13$ (leituras quinzenais-mensais) e nos poços $3,5,6,8,9,10,12$ e 13 (leituras de 4 em 4 dias)

ANEXO 4: Gráficos: Precipitação - oscilação do nivel freático nos poços de monitoramento 1 , $2,3,4,5,6,7,8,9,10,12,13$, Figuras 1 a 12, respectivamente (leituras quinzenais-mensais)

ANEXO 5: Gráficos: Precipitação oscilação do nivel freático nos poços de monitoramento do terreno terciário $3,5,6,8,9,10,12$ e 13.

ANEXO 6: Planilhas:

Tabela 1 - Dados pluviométricos do Posto Água Branca.

Tabela 2 - Resultados das análise químicas nos poços de monitoramento

Tabela 3 - Resultados das análises químicas nas nascentes. 


\section{LISTA DE SIGLAS E ABREVIATURAS}

(em ordem alfabética)

AR-LA: Administração regional da Lapa

COE: Novo Código de Edificações

EMURB: Empresa Municipal de Urbanização

GAP: Galeria de Águas Pluviais

INMET: Instituto Nacional de Meteorologia

IPT: Instituto de Pesquisas Teconológicas do Estado de São Paulo

NTO: Normas Técnicas Oficiais

OMS: Organização Mundial de Saúde

PMSP: Prefeitura Municipal de São Paulo

SABESP: Companhia do Saneamento Básico do Estado de São Paulo

SCS: Soil Conservation Service

SEMPLA: Secretaria do Planejamento do Município de São Paulo

SPT: Standard Penetration Trade 


\section{RESUMO}

Os efeitos da urbanização sobre a recarga aqüífera são freqüentemente mencionados na literatura em nivel qualitativo, com raros estudos abordando a sua quantificação.

O principal objetivo do presente estudo foi a avaliação da recarga direta e indireta no aqüífero freático de uma área intensamente urbanizada. Duas sub-bacias contíguas (Sumaré e Pompéia) foram escolhidas como área piloto, ambas pertencentes à bacia do Rio Tietê, localizadas na porção cento-oeste do municipio de São Paulo, cobrindo uma área de $9,6 \mathrm{~km}^{2}$ e com um índice de impermeabilização total estimado em $73 \%$.

A área está geologicamente localizada na Bacia Sedimentar de São Paulo, de idade terciária, constituida de camadas e lentes arenosas, siltosas e argilosas, que cobrem $66 \%$ da área de estudos, com espessura média de $80 \mathrm{~m}$, e os $33 \%$ restantes são ocupados pelos aluviōes quaternários das várzeas do Rio Tietê. $O$ desnivel altimétrico é bastante elevado (111 m), variando de 721 a 832 metros.

O regime climático é marcado por dois períodos, sendo um seco, de abril a setembro, e outro úmido, de outubro a março. A média anual de precipitação é de $1500 \mathrm{~mm}$.

O método para cálculo da recarga direta foi a medida direta, por um periodo de 14 meses, da oscilação do nível freático em 13 poços de monitoramento perfurados para este fim. A profundidades desses poços variaram de 3,4 a $12,0 \mathrm{~m}$, e o nível d'água médio é de $2 \mathrm{~m}$ no aqüífero quaternário e $7,3 \mathrm{~m}$ no nivel mais profundo do terciáio.

A porosidade efetiva empregada no cálculo do armazenamento foi de 0,13 . A recarga total obtida representou aproximadamente $3,6 \%$ da precipitação anual (1818 mm - out/94 set/95), e $25 \%$ da que seria obtida considerando-se uma situação de pré-ocupação da bacia.

A recarga indireta correspondeu às perdas físicas da rede de abastecimento de água (adutoras e ligações domésticas). Com base em dados fornecidos pela Companhia de Saneamento Básico do Estado de São Paulo (SABESP), estimou-se uma perda total correspondente a $532 \mathrm{~mm}$, que representa cerca $89 \%$ da recarga total.

O estudo abrangeu ainda uma análise da eficácia dos microrreservatórios de retenção temporária, para controle de enchentes, previstos em lei do municipio de São Paulo. $O$ amortecimento, em termos de volume, representou $30 \%$ do mínimo necessário. Os métodos empregados para cálculo do escoamento superficial e a geração dos hidrogramas, foram a equação de Horton e o método de Santa Bárbara, respectivamente.

Os resultados mostraram a significativa redução da infiltração devida à impermeabilização urbana e a necessidade de reformulação da Lei municipal de forma a tornar o sistema de microrreservatórios tecnicamente mais eficaz e a sua implantação economicamente viável do ponto de vista construtivo, de manutenção e fiscalização. 


\section{ABSTRACT}

The aim of this investigation was direct and indirect recharge evaluation of the freatic aquifers in a densely and urbanized area. The target area was two sub-basins in the Tietê River basin, city of São Paulo, Brazil. The Sumaré and Pompéia sub-basins are localized in the middle-west of the city, the extend of area is $9.6 \mathrm{~km}^{2}$, and the impervious surface is approximately $73 \%$.

The study area is inserted in the Terciary Sedimentar Basin of São Paulo, constituted of sandy, silt and clay layers. This litology cover $66 \%$ of the area, about $80 \mathrm{~m}$ thick, and the other $33 \%$ are constituted by quaternary sediments Tietê River. The difference between altimetrics level is very accentuated, $111 \mathrm{~m}$ (721 to $832 \mathrm{~m}$ above sea level).

The rainfall pattern is characterized by the occurrence of a dry period between april and september and of a wet period from october to march. The mean annual rainfall is $1500 \mathrm{~mm}$.

The evaluation method for direct recharge was realized by the direct measurements of the water table fluctuations of 13 monitoring wells during 14 months. The deep these wells varies of 3,4 to $12 \mathrm{~m}$, the mean freatic level is $2 \mathrm{~m}$ in quaternary aquifer and $7.30 \mathrm{~m}$ in the terciary aquifer.

Effective porosity was adopted constant for the total aquifer as a 0.13 . The overall recharge was $3.6 \%$ of the annual precipitation (1818 $\mathrm{mm}$ - october/94 to septembert/95), representing only $25 \%$ of the recharge that would have been achieved for the original basin conditions (without today urbanized on).

Indirect recharge actually corresponded water leakage from the public network of water supply (water mains and domestic connections). Based on data of supplied by São Paulo State Basic Sanitation Company (SABESP), the total estimated loss correspond to $532 \mathrm{~mm}$, i.e, $89 \%$ of the overall recharge.

In the study, was also analyzed the theoretic efficiency of the so called microreservoirs of temporary retention that, according to municipal laws, should be used for control floods. The mitigation in terms of volume represents only $30 \%$ of necessary minimum. The methods applied to estimate run off and to produce hidrograms were the indirect methods, the Horton equation and Santa Barbara, respectively.

The results showed significative infiltration losses due to urban impermebilization an the necessity of the reformulation of municipal laws in order to make the construction of microreservoirs effective, as well technical and economically feasible. 


\section{INTRODUÇÃO}

A necessidade de estudos quantitativos da recarga aqüifera em ambiente urbano incitou a realização deste trabalho, desenvolvido numa área piloto no município de São Paulo (sub-bacias Sumaré e Pompéia). Os dados obtidos durante a evolução do estudo (características geológicas, fisiográficas e de ocupação) propiciaram uma abordagem do escoamento superficial, principal responsável pelas enchentes urbanas, numa escala em nível de evento de precipitação.

Para um melhor entendimento do processo da recarga direta, esta foi investigada, limitado-se à parte superior do aqüífero, ou seja, ao aqüifero freático. Esta investigação envolveu uma minuciosa caracterização geológica e hidrogeológica desta porção do aqüífero, - comportamento da oscilação do nivel freático e de nascentes, a estimativa da área impermeável, a precipitação durante o período de estudo e o balanço hídrico climático.

A recarga indireta foi estimada a partir de dados de perda física fornecidos pela Companhia de Abastecimento Básico do Estado de São Paulo (SABESP), nos setores de abastecimento envolvidos pela área de estudos.

Embora não se verifique pontos críticos de inundações na área deste estudo, ela faz parte do conjunto de sub-bacias que contribuem diretamente para o aumento do pico das vazões no Rio Tietê, gerando inundaçōes, em vários locais do seu percurso, durante as chuvas intensas.

$\mathrm{Na}$ tentativa de promover o amortecimento dos picos de enchentes, foi criada, em 1989, uma lei do município de São Paulo, que previa o controle dos escoamentos na fonte, por meio da construção de microrreservatórios domiciliares de infiltração e retenção temporária, em função da área impermeável do lote. Realizou-se uma análise quantitativa do amortecimento dos volumes escoados superficialmente, admitindo-se a implantação destes dispositivos na área de estudos.

O texto foi estruturado em sete itens, sendo que nos trés primeiros encontram-se a apresentação geral da área de estudos e o levantamento bibliográfico, abordando os aspectos conceituais e metodológicos investigados, bem como a caracterização geológica e hidrogeológica regional; $O$ item 4 apresenta os materiais e métodos utilizados na realização do estudo e no item 5 foi apresentada a caracterização gelógica, hidrogeológica e físicoclimática local. Os ítens 6 e 7 abordam estudos específicos da recarga aqüifera e escoamento superficial, apresentando-se os procedimentos, cálculos e resultados. 


\section{OBJETIVOS}

Os objetivos principais foram:

- estudo da recarga sazonal no aqüifero freático no ano hidrológico considerado (Outubro/1994 a Setembro/1995), a partir da caracterização e quantificação dos componentes da recarga direta e indireta na área de estudos;

- estimativa da redução da recarga direta, devida à impermeabilização urbana, e

- avaliação, do ponto de vista técnico e funcional, da implantação de microrreservatórios domiciliares de retenção temporária dos escoamentos superficiais para amortecimento dos picos de enchentes, previstos na Lei $11: 228$ de 25 de junho de 1992, do novo Código de Obras de Edificações do Município de São Paulo.

\section{GENERALIDADES}

\subsection{APRESENTAÇÃO DA ÁREA DE ESTUDOS}

$A$ área de estudos compreende as duas sub-bacias hidrográficas contiguas Sumaré e Pompéia, na zona Oeste do município de São Paulo abrangendo uma extensão de $9,6 \mathrm{~km}^{2}$, sendo limitada pelos paralelos $23^{\circ} 31^{\prime} 13^{\prime \prime}$ e $23^{\circ} 33^{\prime} 10^{\prime \prime}$ Sul, e meridianos $46^{\circ} 39^{\prime} 05^{\prime \prime}$ e $46^{\circ} 41^{\prime} 39^{\prime \prime}$ Oeste de Greenwich.

As sub-bacias Sumaré e Pompéia são drenadas pelos dois córregos principais Água Preta e Sumaré, com extensão de $4,5 \mathrm{~km}$ e $4,0 \mathrm{~km}$, respectivamente, de acordo com a Empresa Municipal de Urbanização (EMURB (1974)).

A área de estudos é limitada a leste e a oeste pelos divisores hidrográficos das subbacias, a norte pelo curso do Rio Tietê, e a sul pelo interflúvio das Bacias Pinheiros e Tieté (Figura1). Neste interflúvio, geomorfologicamente denominado espigão central, estão implantadas, na área, trechos da av. Heitor Penteado (entre as Ruas Aurélia e Caiowas) e da av. Dr. Arnaldo (entre a rua Cardoso de Almeida e a rua Bruxelas).

Sob o aspecto geológico a área está inserida na Bacia Sedimentar de São Paulo, sendo que cerca de $66 \%$ é coberta pelos sedimentos terciários e os demais $33 \%$ pelos sedimentos quaternários pela várzea do rio Tietê.

Urbanisticamente a área é bem consolidada, apresenta ocupação adensada (com exceção da região de várzea), e os bairros nela existentes podem ser vistos dentre os mais bem servidos de infraestrutura urbana do municipio, sendo totalmente abastecida pela rede de água e provida de rede de esgotos em quase sua totalidade, em mais de $90 \%$ (PMSP/SEMPLA, 1993). 


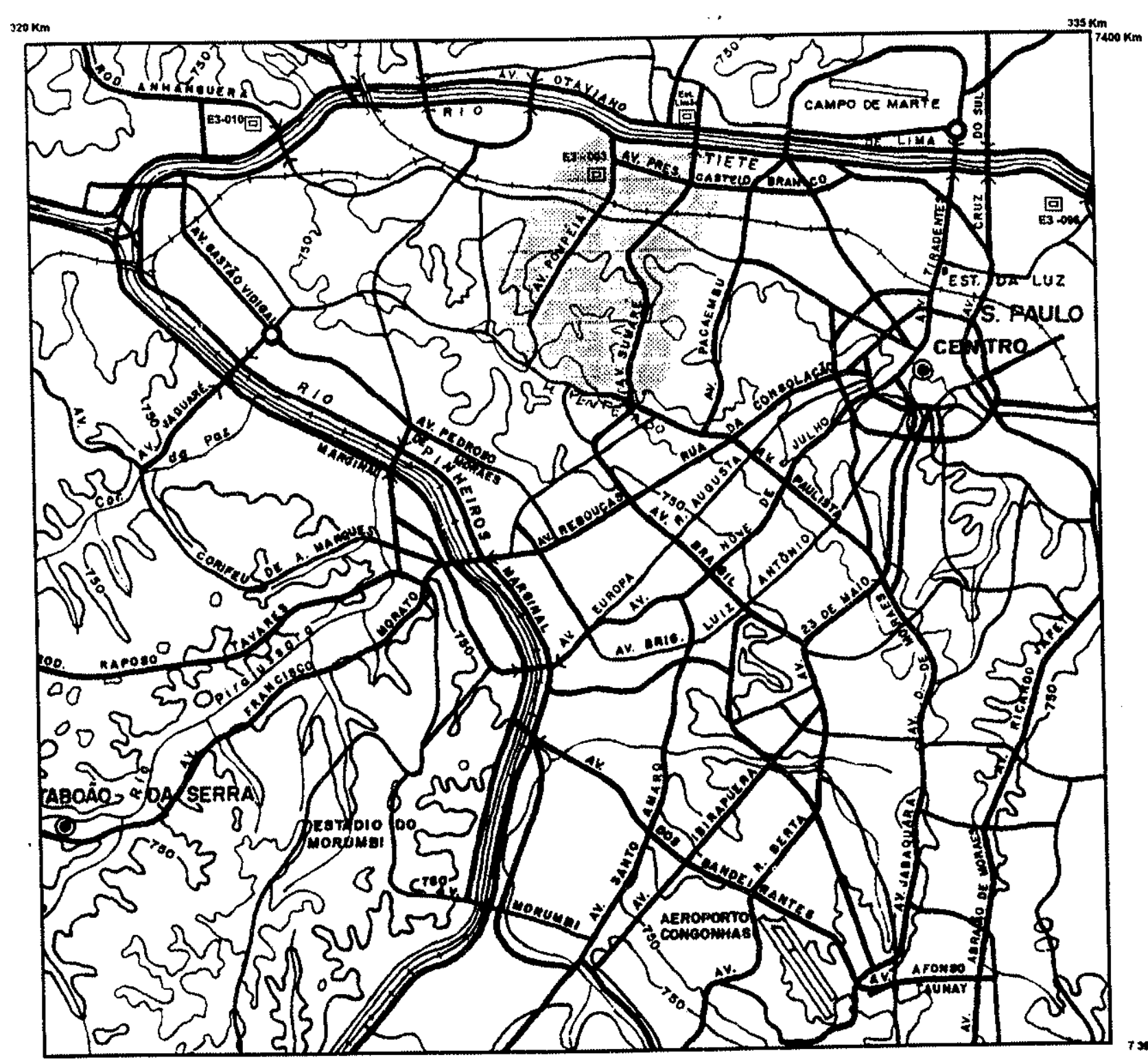

FIGURA 1 - Mapa de Localização da Área

LEOENDA

(Modificado de EMPLASA, 1980)
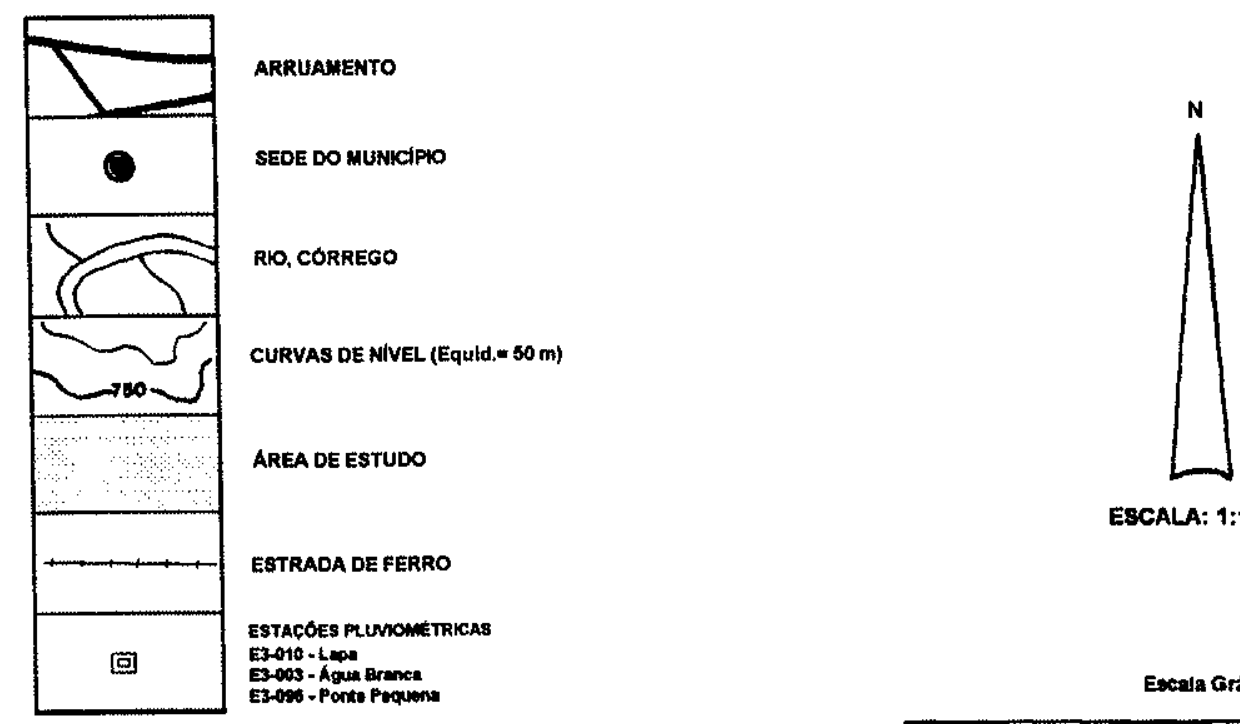

ESCALA: 1:100,000

Excala Gráfica

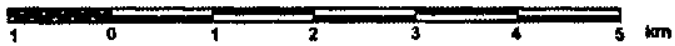


Os bairros mais importantes, parcial ou totalmente contidos na área de estudos, no domínio da vázea são: Barra Funda, Água Branca e Lapa de Baixo. No domínio dos sedimentos encontram-se os Bairros Lapa, Sumaré, Perdizes, Pompéia e Vila Romana. (Figura 2).

$\mathrm{Na}$ área de estudos, a quase totalidade dos terrenos de várzea, pela legislação vigente, é destinada ao uso especial (industrial, recreação, dentre outros). No restante da área, o zoneamento de uso do solo é variável, em função da ocupação ser residencial, comercial ou de caráter misto, com predomínio do último tipo.

No sistema viário pode-se distinguir as avenidas implantadas em fundo de vales (av. Sumaré, sob a qual escoa o córrego Sumaré, e partes da av. Pompéia); no espigão, as av. Dr. Arnaldo e Heitor Penteado, e, as vias estruturadoras da várzea (av. Castelo Branco, que segue junto à marginal do Rio Tietê e av. Marquês de São Vicente).

\subsection{JUSTIFICATIVAS PARA A REALIZAÇÃO DO ESTUDO E ESCOLHA DA ÁREA}

A preocupação com a quantificação da recarga nos centros urbanos, somente na última década começou a tomar vulto, em função dos seguintes fatores:

- expansão e impermeabilização generalizada dos centros urbanos, diminuindo assim, as possibilidades de recarga natural dos aqüiferos.

- aumento da exploração da água subterrânea nos centros urbanos, em razão dos custos da água tratada, freqüentes interrupções de abastecimento pela rede pública, e até mesmo total ausência desta rede em alguns núcleos urbanos;

- aumento do potencial de poluição dos aqüiferos, devido à diversidade de nascentes de poluição introduzidas pelas atividades humanas, $e$

- aumento da freqüência de ocorrências de enchentes nas cidades.

O Municipio de São Paulo retrata muito bem as questões acima relacionadas, encerrando determinadas zonas com elevados índices de impermeabilização, tal como a área escolhida para a realização deste estudo.

Os estudos hidrogeológicos existentes na Região Metropolitana de São Paulo são geralmente de caráter regional, englobando litologias diversas, áreas com diferentes estágios e formas de ocupação do solo, e de diferentes niveis de infraestrutura quanto ao saneamento, fatores estes que interferem na quantificação e nos processos de recarga, que necessitam, portanto, ser considerados. Constata-se, assim, uma carência de estudos mais detalhados relacionados à quantificação da recarga dos aqüiferos. 
Quanto aos estudos que reportam sobre a hidrologia superficial, estes são muitos, existindo em várias escalas, principalmente, em função dos projetos convencionais para obras de macro e microdrenagem. Porém, abordagens de medidas de controle do escoamento superficial, no seu local de origem (source control) são raros ou inexistentes na RMSP.

Para a realização desta pesquisa foi, então, selecionada uma área física, densamente urtuanizada e provida de caracteristicas bastante importantes ao objetivos propostos:

- ocupação do solo: as características de ocupação se estendern também às áreas limitrofes, a leste, oeste e sul da área de interesse. Além disso, o elevado grau de urbanização possibilita resultados da influência extrema da impermeabilização sobre os escoamentos considerados (infiltração e runoff);

- contexto geológico: as litologias são bem conhecidas, verificando-se também uma continuidade lateral entre as formações litológicas para além da área;

- condições de contorno: os limites da área, correspondentes a trés divisores hidrográficos, proporciona um sistema relativamente fechado, com pouca influência de áreas vizinhas, podendo-se considerar que eventuais perdas hídricas para as bacias adjacentes podem ser compensadas por eventuais entradas;

- disponibilidade de dados: existem estações pluviométricas tanto dentro dos limites, quanto no entorno da área, além de dados relativamente confiáveis, quanto às perdas de água pela rede de distribuição da SABESP, e

- localização: o posicionamento centralizado dentro do município favorece o acesso à área, principalmente durante a fase de monitoramento, minimizando os custos de transporte durante as pesquisas de campo. 


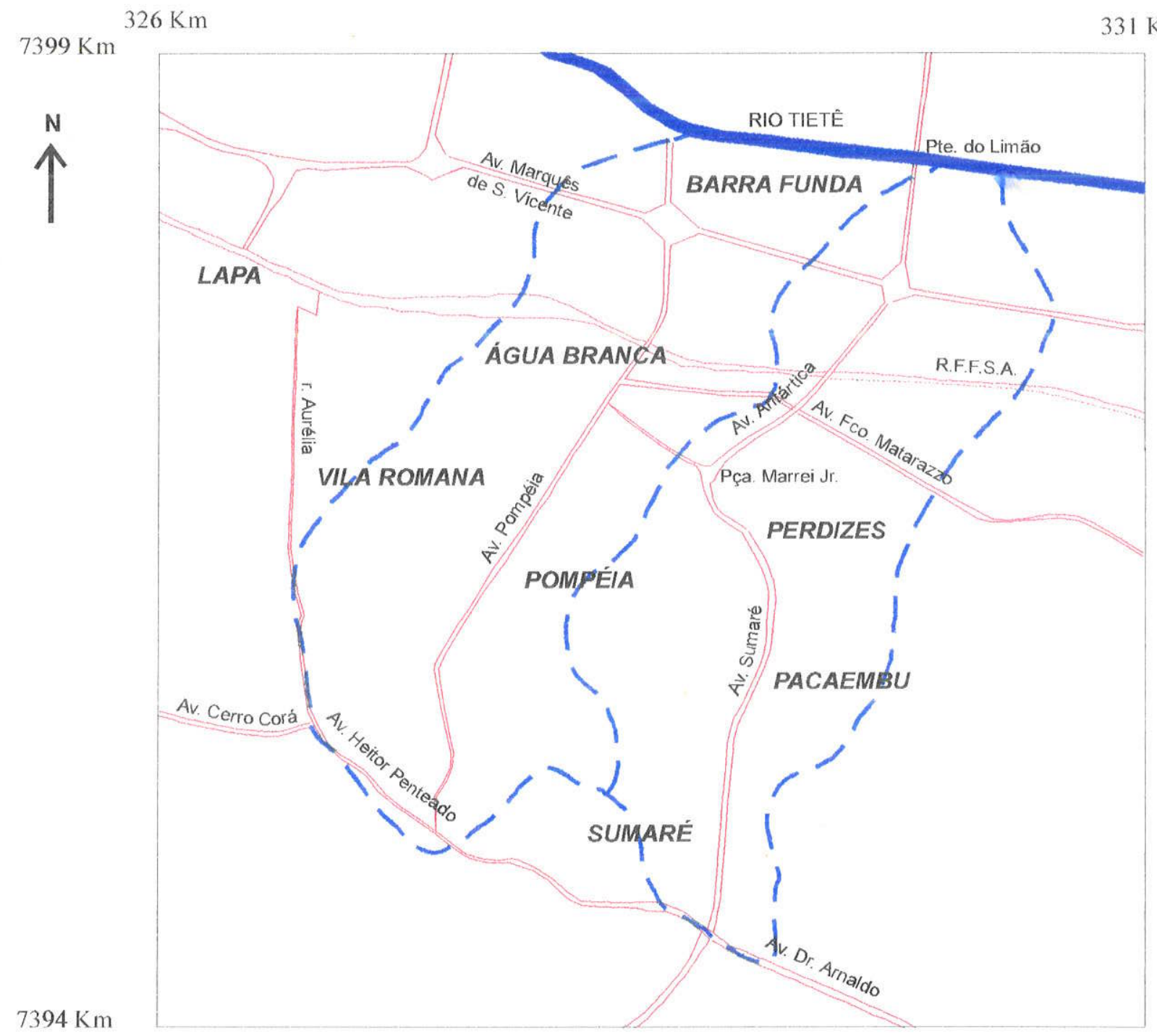

FIGURA 2 - Mapa do Sistema Viário e Bairros

\section{LEGENDA}

Limite dá área (divisor hidrográfico)

ruas ou avenidas

ferrovia

\section{$\stackrel{0}{100}_{-200}^{200}$}

ESCALA GRAFICA

$331 \mathrm{Km}$ 


\section{FUNDAMENTAÇÃO TEÓRICA: CONCEITOS, ASPECTOS METODOLÓGICOS E ESTUDOS INVESTIGADOS NA LITERATURA}

Projeçöes estatísticas prevêem que ao final deste século, cerca de $50 \%$ da população mundial será urbana, sendo que o processo de urbanização é mais acelerado nos paises em desenvolvimento. A exemplo do Brasil, que ao longo dos últimas décadas apresentou um crescimento significativo da população urbana, criando as denominadas "regiões metropolitanas", apresenta atualmente um indice de população urbana de $80 \%$, próxima da saturação (TUCCI, 1995).

Concomitantemente aos processos de urbanização brasileira, criam-se outros problemas, como a reduzida dimensão dos lotes, resultando num maior adensamento urbano, o qual é ainda mais intensificado pelo predomínio da cultura da pavimentação domiciliar, em substituição aos jardins visando a um maior aproveitamento do terreno.

Os impactos da urbanização implicam profundas alterações do regime hidrológico, estabelecendo-se um novo microclima, caracterizado por um aumento da temperatura anual; aumento do vapor d'água; aumento da nebulosidade, e aumento da convecção e turbulência. Uma das conseqüências dessas alterações climáticas é a ocorrência de precipitações, principalmente do tipo convectivo, caracterizado por chuvas de grande intensidade e curta duração, que provocam os fenômenos de inundações (DAEE, 1989).

Os efeitos da urbanização sobre os fluxos sub-superficiais, escoamento superficial (runoff), infiltração e recarga subterrânea foram amplamente investigados pelo Committee on Surface-Water Hydrology of the Hydraulics Division, em 1975. Mais de 900 referências foram examinadas, predominantemente experiências nos Estados Unidos, tendo-se constatado àquela época que havia poucas informações quantitativas sobre as implicações dos efeitos da urbanização sobre a condução dos recursos hídricos.

Dois tipos de recarga aqüifera podem ser distinguidos: a recarga direta e a indireta. A recarga direta é o volume de água adicionada ao reservatório de água subterrânea por percolação vertical direta da precipitação através da zona não-saturada. (FAO, 1981, LLOYD, 1986, in LERNER et. alli, 1990). No meio urbano esta recarga evidentemente se processa pela infiltração natural nas áreas não impermeabilizadas.

A recarga indireta resulta da percolação até o aqüifero, advindas do escoamento superficial, a partir dos leitos de cursos d'água existentes na superficie do terreno, e das fontes de infiltração introduzidas pela urbanização.

A redução da infiltração direta é, em contrapartida, amplamente compensada pelos aportes da recarga indireta, diminuindo dessa foma os efeitos da urbanização sobre a 
recarga, podendo mesmo superá-la. Estima-se que nos paises em desenvolvimento as perdas das redes de distribuição alcançam cerca de $50 \%$ da adução, enquanto em países industrializados se situam ao redor de 15\% (GARDÑO, 1994).

Citam-se como fontes de infiltração indireta mais significativas nas áreas urbanas:

- vazamentos do sistema de adução e distribuição de água;

- vazamentos das redes de águas pluviais (galerias);

- vazamentos das redes de águas servidas, ou esgotos;

- irrigação de parques e jardins públicos e domicilicares;

- vazamentos de tanques sépticos;

- infiltração a partir de bacias de efluentes domésticos e industriais.

- infiltração a partir das enxurradas.

Para melhor ilustrar os efeitos da urbanização sobre a água subterrânea e hidrologia superficial a Figura 3 indica os componentes hídricos mais significativos no sistema hidrológico urbano, apresentado por LERNER (1990). Nesta figura são mostrados os fatores determinantes da redução e do acréscimo da recarga aqüifera urbana, o aumento do volume do escoamento superficial e as possíveis interações água superficial-água subterrânea.

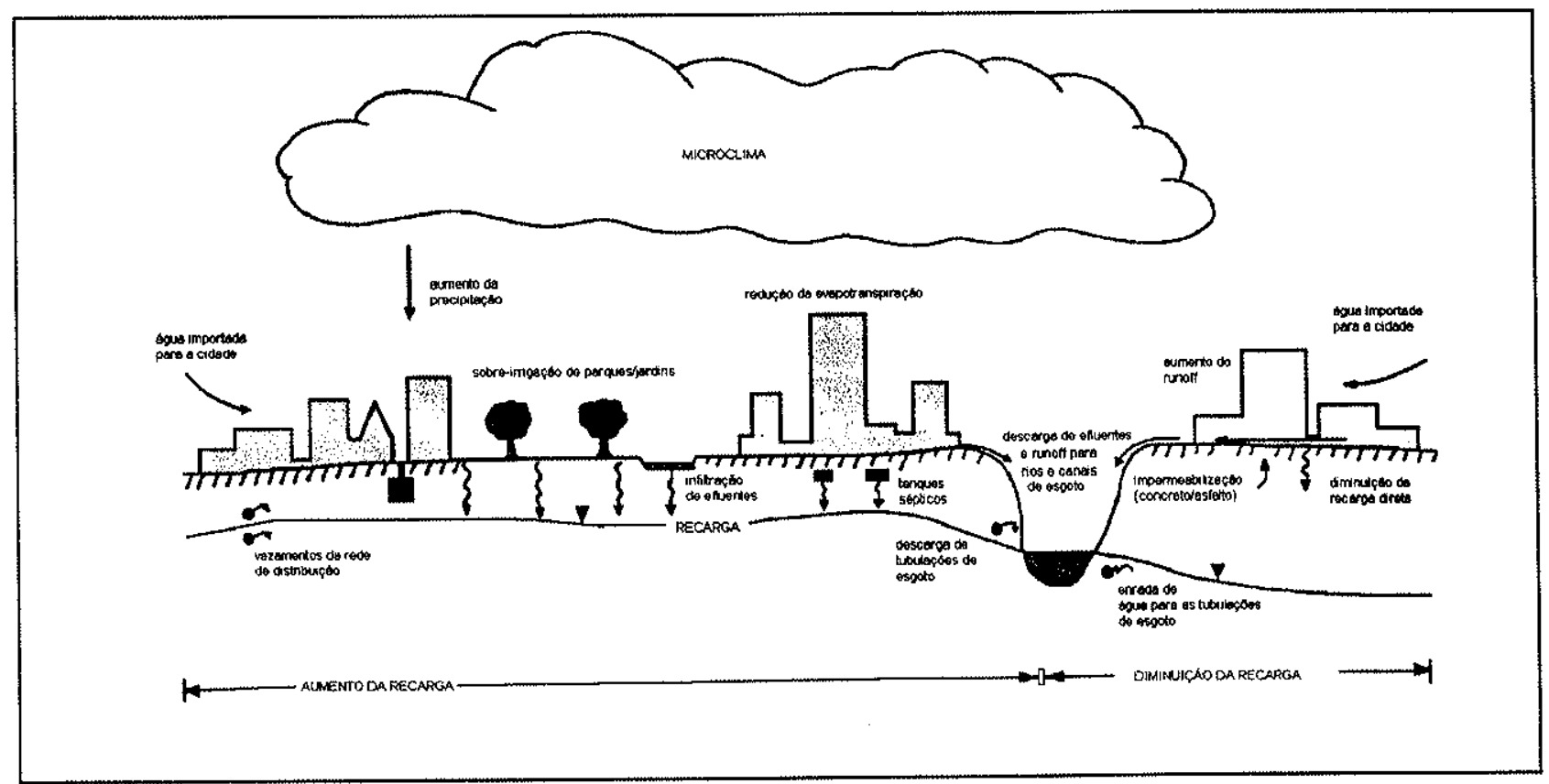

FIGURA 3 - Principais componentes do sistema hidrológico urbano (LERNER, 1990)

Uma revisão da literatura mostrou muitos casos históricos, onde, dependendo da situação individual, a taxa de recarga de água subterrânea no meio urbano não foi afetada, foi 
diminuída ou foi aumentada (COMMITTEE ON SURFACE-WATER HYDORLOGY OF THE HIDRAULICS DIVISION, 1975)

O efeito da urbanização que mais produz impacto, pelo seus efeitos muitas vezes catastróficos, e que mais tem recebido atenção, é o aumento dos picos de vazão dos escoamentos superficiais, que implicam enchentes dos rios e inundações localizadas.

Com a urbanização o tempo de concentração é reduzido; a largura do hidrograma resultante é freqüentemente encurtada, e o pico é aumentado em relação ao hidrograma sob condições naturais.

Medidas alternativas para promover o retardamento do pico de escoamento superficial, distribuindo a vazão no tempo são amplamente divulgadas na literatura, citando-se:

a nivel de micro escala:

- armazenamento em teihados (GENZ, 1995);

- tanques residenciais (GENZ, 1995; YOSHIMOTO, 1990);

- poços subterrâneos de infiltração (OAKSFORD, 1985; LERNER, 1990);

- trincheiras subterrâneas de percolação (DAEE, 1989; MUSIAKE, 1994);

a nível de macro escala:

- reservatórios subterrâneos de detenção (CANHOLI, 1994,);

- reservatórios aéreos de regularização;

- reservatórios aéreos de detenção.

Apresenta-se abaixo um resumo das causas-efeitos da urbanização sobre os escoamentos superficial e subterrâneo.

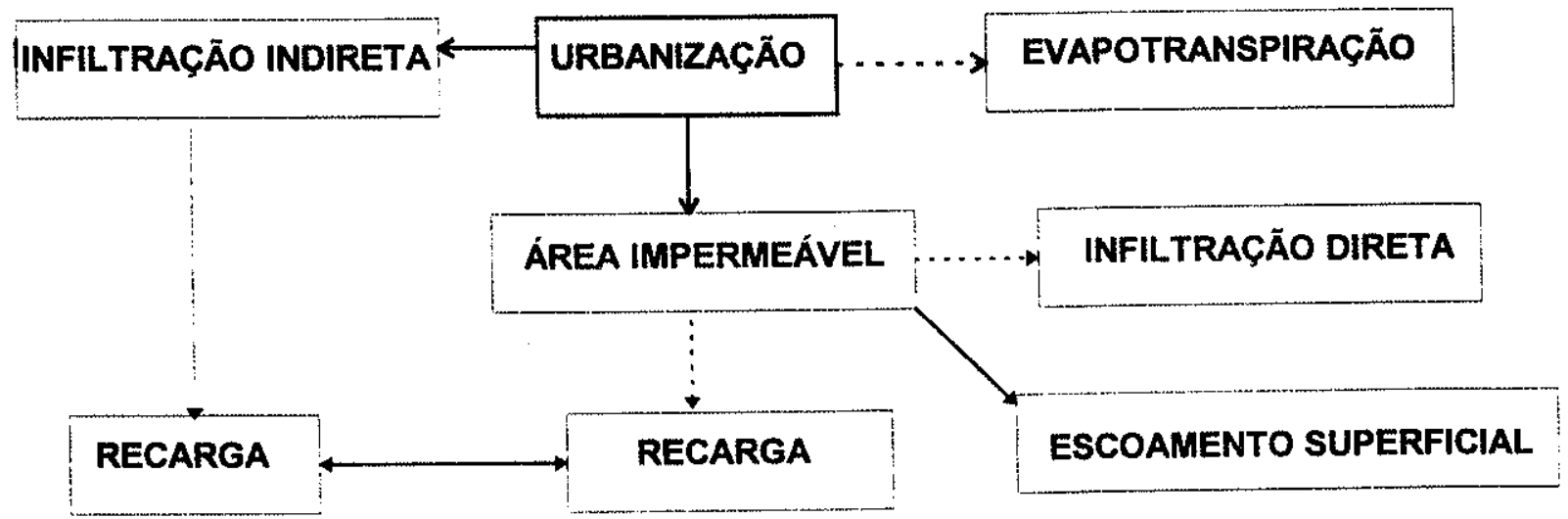

Legenda: 


\subsection{FATORES QUE INFLUEM NA RECARGA AQÚIFERA E NO ESCOAMENTO}

\section{SUPERFICIAL}

\subsubsection{Recarga}

Como bem enfatizado por GEE (1988), a recarga de água subterrânea não depende apenas do regime climático, isto é, dos fatores de precipitação e evapotranspiração, mas também da natureza do solo e da sua cobertura vegetal.

RUSHTON (1988) in LERNER (1990) classificou seis fatores que podem afetar a recarga, de uma forma geral: 1. Superficiais: topografia; precipitação (magnitude, intensidade, duração, distribuição espacial); escoamento superficial, reservatórios d'água; características e padrão da vegetação; 2 . Zoneamento do solo: natureza do solo, profundidade, propriedades hidráulicas; variabilidade lateral e em profundidade; presença de fissuras quando o solo apresenta-se seco ou intumescido; 3. Zona não-saturada: mecanismo de fluxo através da zona saturada; zoneamento da condutividade hidráulica; 4. Aqülferos: possibilidade do aqüifero de receber água; variação das condições aqüíferas com o tempo; 5 . Rios: rios que escoam para fora ou para dentro da bacia considerada; rios que perdem ou ganham água em relação ao aqüifero, e, 6. Imigação: forma de irrigação; perdas por canais e cursos d'água; formas de manejo do solo.

Em área urbanas estes fatores são acrescidos das formas de ocupação, isto é, da quantidade e características das áreas livres da impermeabilização, acrescentando-se ainda o grau de urbanização e saneamento que implicam maior ou menor proporção dos volumes de recarga indireta, como já explicitado nos parágrafos precedentes.

\subsubsection{Escoamento superficial direto}

O escoamento superficial direto é também denominado chuva efetiva, definida como aquela parte da chuva que se torna escoamento (CETESB, 1980).

Os fatores que controlam o volume do escoamento superficial em uma área urbana são (CETESB, 1980):

- características da precipitação: magnitude, duração e freqüência;

- áreas permeáveis e impermeáveis: o acréscimo da área impermeável resulta em significativas mudanças na relacão precipitação-deflúvio.

- perdas por armazenamento em depressões e por detenção (intercepção pelas folhas e telhados), sendo que a maior parte é evaporada, e 
- infiltração: a infiltração na área urbana depende da quantidade de áreas disponiveis à infiltração, do tipo de cobertura (vegetal ou solo nu), da declividade da superficie do terreno, constituição granulométrica do solo, grau de compactação do solo, etc.

No inicio da precipitação sobre um solo com baixa umidade, o preenchimento dos vazios do solo provoca uma infiltração máxima, e à medida que a chuva continua, a taxa de infiltração decresce, tendendo a um valor mínimo. Quando a chuva ocorre em uma área de baixa umidade antecedente, a taxa de infiltração é muito maior do que a que se verificaria na mesma área com alta umidade antecedente decorrente de chuvas anteriores.

\subsection{MÉTODOS DE ESTIMATIVA DA RECARGA}

Variações na recarga no tempo e no espaço (lateral e verticalmente) são conseqüências diretas de fatores, tais como a precipitação, características do solo, vegetação, ocupação do solo e topografia.

Diante desta variabilidade de fatores, quais as melhores técnicas a serem usadas e que reproduzem estimativas de recarga mais confiáveis ? A resposta a esta questão depende de vários fatores que influenciam a escolna do método adequado e mais confiável. Avaliações destes fatores são aqui apresentadas, primeiramente para estudos de recarga de uma forma geral, e posteriormente para estudos estimativos específicos em áreas urbanas.

A recarga a partir de cada origem pode ser quantificada por vários métodos, os quais apresentam similaridades entre si para diferentes origens. LERNER (1990) classifica em 5 os métodos de estimativa de recarga:

- medida direta;

- balanço hidrico;

- aproximação darciniana;

- técnicas por traçadores

- outros, principalmente métodos empíricos.

Uma breve abordagem das características, vantagens e desvantagens e escala de tempo de cada um desses métodos é apresentada a seguir de acordo com o autor acima citado.

a) medida direta:

Apenas a recarga da precipitação e as perdas por canais são medidas diretamente com qualquer frequência. Medidas diretas têm as vantagens de se constituir num balanço de massa implícito. A superestimação da recarga é improvável e a escala de tempo de medições é aquela das observações, variando de instantâneas, sazonais ou anuais. 


\section{b) Balanco Hidrico:}

Inclui um grupo de métodos estimativos, cujo principio é que outros fluxos podem ser medidos ou estimados mais facilmente do que a própria recarga, que constitui no residual de todos os outros fluxos. Como exemplos de métodos de balanço hidrico podem ser citados:

- Controle da umidade do solo com instrumentos próprios e da precipitação e evapotranspiração potencial, tendo como resultados a evapotranspiração real e a recarga;

- balanço hídrico de canais e rios;

- elevação do nível d'água - quando o volume armazenado, medido pela elevação do nível freático, é calculado levando-se em consideração entradas e saidas d'água do sistema aqüifero, tais como bombeamentos e fluxos interaqüiferos.

As vantagens dos métodos de balanço hídrico são que eles utilizam dados disponiveis (precipitação, runoff, niveis d'água), e são aplicáveis para todas as origens de recarga. As desvantagens são os erros acumulados de todos os outros fluxos, além da dificuldade de estimar estes fluxos (como por exemplo a evapotranspiração) e as propriedades físicas, como a capacidade específica.

O tempo de escala natural é a duração de um evento de recarga. Como os processos de recarga são freqüentemente não-lineares, a estimativa da recarga baseada em grandes intervalos de tempo deve constituir na soma de todos os eventos individuais.

c) Aproximações Darcinianas

O fluxo de água subterrânea é controlado pela lei de Darcy:

$$
q=K i \text { ou } Q=K i A
$$

onde:

$q=$ velocidade do fluxo $(L / T)$

$\mathrm{K}=$ condutividade hidráulica (L/T);

$i=$ gradiente hidráulico: $-\mathrm{dh} / \mathrm{dx}$;

$Q=$ fluxo através de uma secção $\left(\mathrm{L}^{3} / \mathrm{T}\right)$;

$A=$ área da secção $\left(L^{2}\right)$;

Há duas formas de estimativa da recarga:

- medições de campo - normalmente assumem condições estáticas, quando apenas medidas de nivel (ou pressão) e condutividade hidráulica são necessárias. Os métodos são bons para fluxos saturados, pois para fluxos no meio não-saturado, os valores de condutividade hidráulica são muito sensiveis ao conteúdo de umidade.

- Modelamentos numéricos - consideram fluxos não permanentes e variações no armazenamento, podendo-se incluir a variabilidade espacial de propriedades fisicas, das quais a condutividade hidráulica é a mais importante. 
A principal vantagem è que o método procura representar os processos físicos atuais do fluxo, que normaimente são efetuados assumindo-se simplificações para reduzir o trabalho computacional, por exemplo: emprego de uma porosidade média sem variações espaciais.

A escala de tempo depende da velocidade de flutuação dos niveis, variando de segundos, para precipitação no solo, a sazonal ou maiores, para percolação entre aqüiferos.

\section{d) Técnica de traçadores}

Traçadores ambientais e artificiais são geralmente usados em regiões áridas e semiáridas.

São amplamente usados para estudos da recarga total, da precipitação e irrigação, mas não são adequados para quantificação de recarga urbana.

A desvantagem é que pode haver subestimação ou superestimação, devido ao fato de os traçadores não serem medidos diretamente do fluxo d'água.

Traçadores ambientais permitem estimar a recarga sobre longos períodos de tempo em áreas áridas e semi-áridas, indo de dezenas de anos quando perfilado em zonas nãosaturadas, a centenas de anos para o aqüifero. Traçadores artificiais são usados onde a recarga é alta, podendo agir sobre uma ou várias estações.

e) Outros métodos

São principalmente métodos empíricos, em que a recarga é correlacionada com outras variáveis (pecipitação, elevação do nivel d'agua, fluxo dos canais). A relação é então usada para: (a) ampliar-se o registro de recarga no tempo ou (b) transposição para outros locais de características similares.

Um dos problemas é o efeito dos níveis d'água sobre o cálculo da recarga: níveis elevados ou niveis de aqüiferos suspensos poderão reduzir a recarga calculada, algumas vezes em várias ordens de grandeza.

A profundidade da água subterrânea é o fator mais difícil de se correlacionar entre os sistemas, e os métodos empíricos aplicam-se melhor quando o nível d'água é profundo e não ocorrem aqülferos suspensos.

As desvantagens são as alterações nas condicões do aqüifero (explotação do recurso), que podem alterar a recarga, pois os métodos empíricos não podem estimar estas variações, porque os modelos não envolvem os processos de recarga.

\subsubsection{Fatores que influenciam a escolha do método}

Dois fatores básicos influenciam a escolha do método a ser adotado para estimativa da recarga: 
Processos de recarga, que por sua vez dependem de:

$\diamond$ Clima;

$\checkmark$ Caracteristicas geológicas, fisiográficas e hidrográficas.

$\diamond$ Origens da recarga existentes no sistema;

Objetivos do estudo

\subsubsection{Processos de recarga}

$\checkmark$ Clima

Em regiões úmidas a precipitação geralmente excede à evapotranspiração, resultando na infiltração durante a maior parte das estações. O mesmo não ocorre em regiões áridas, nas quais a evapotranspiração potencial (ETP) excede a precipitação na maior parte do tempo (FREEZE, (1979); KNUTSSON (1988); GEE (1988)), ocorrendo episódios descontínuos de recarga no tempo.

Uma análise comparativa entre os processos da recarga em regiões de clima úmido e de clima árido foi apresentada por KNUTSSON (1988). O autor aborda os aspectos relativos à precipitação, vegetação, runoff, percolação da água no solo, congelamento do solo, nível d'água e áreas de recarga e descarga, concluindo que estes diferentes aspectos implicam a aplicação diferenciada das técnicas de recarga, enfatizando que técnicas baseadas no balanço hidrico ou de fluxo no solo são mais importantes em regiōes de clima úmido que em clima árido.

GEE (1988) fazem uma revisão critica dos diferentes métodos de recarga $\mathrm{em}$ regiões áridas, concluindo que o uso de lisímetros e técnicas com traçadores $\left({ }^{36} \mathrm{Cl}\right.$ ou $\left.{ }^{18} \mathrm{O}\right)$ são os meihores métodos para quantificação da recarga nessas regiōes.

\section{- Caracteristicas geológicas e fisiográficas}

A característica geológica determinante nos processos da recarga, e que indiretamente influi na escolha dos métodos de estimativa da recarga, é a granulometria do solo poroso na zona não-saturada, a qual detemina a profundidade do lençol freático.

Os padrões de relevo determinam a maior ou menor infiltração, a qual aumenta para declividades menores.

\section{$\checkmark$ Origens da recarga}

A escolha do método de estimativa de recarga deve levar em conta também as origens da recarga existentes no sistema, as quais devem ser consideradas separadamente. As principais origens de recarga são apresentadas por LERNER (1990):

- precipitaçăo ou recarga direta; 
- recarga por rios (perenes, sazonais e efêmeros);

- fluxos interaqüiferos;

- perdas por irrigação, e

- recarga urbana (indireta)

Cada uma destas origens podem determinar a velocidade e sentido dos fluxos a a frequência dos episódios de recarga.

\subsubsection{Objetivos do Estudo}

A partir dos objetivos do estudo da recarga define-se a escala de tempo de observação requerido, que contribuem na determinação dos métodos. LERNER (1987) in LERNER (1990) apresenta vários fatores que influenciam a escolha do intervalo de tempo para estimação da recarga, observando-se que o objetivo é primordial. A Figura 4 mostra que, embora um método particular possa ser aplicado sobre um grande espectro de escalas de tempo, alguns intervalos são mais apropriados que outros.

ESCALA DE TEMPO

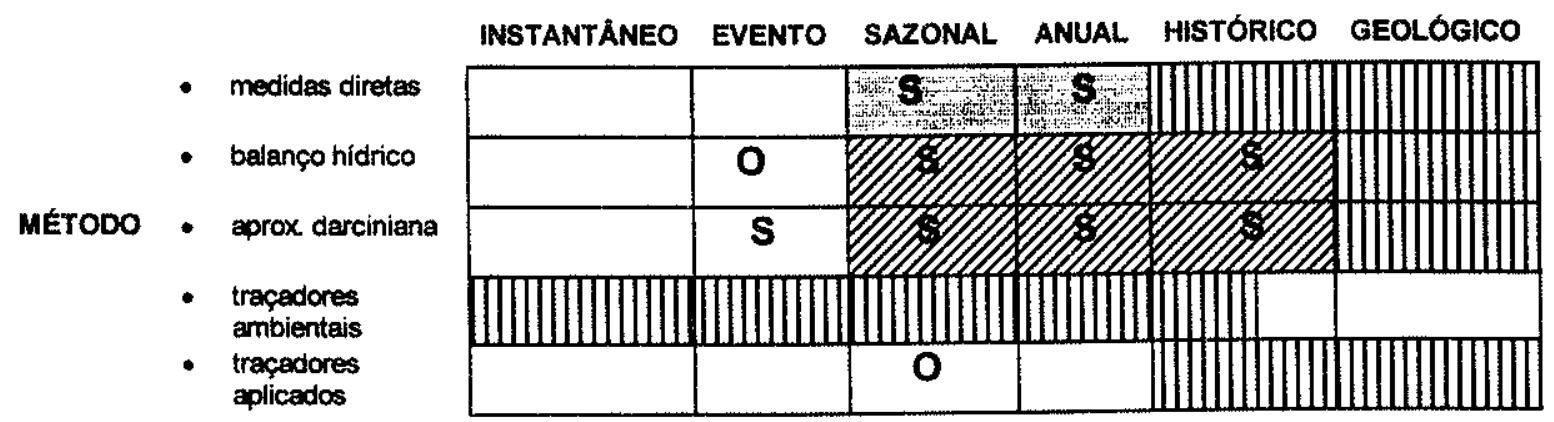

LEGENDA

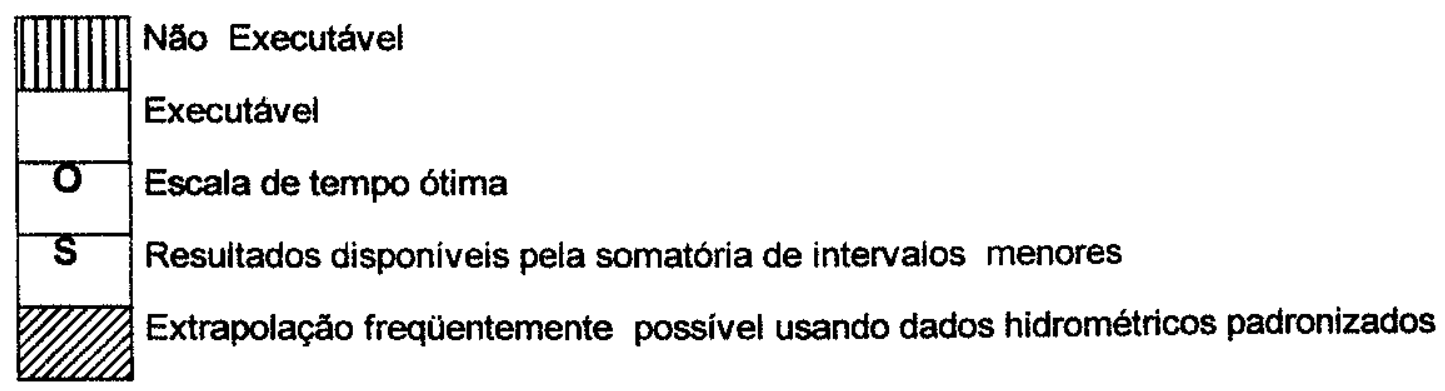

FIGURA 4 - Escalas de tempo para estimativa da recarga direta

(LERNER, 1987) 
2.2.2 Métodos de estimativa de recarga aplicados em áreas urbanas

A variedade de fontes de recarga indireta no meio urbano e a complexidade dos processos envolvidos restrigem os estudos quantitativos.

Os fatores que influenciam o estudo da recarga em uma área urbana são: precisão requerida, definida pela fase da investigação (reconhecimento ou estudo), o tamanho da área urbana, o volume do suprimento de água, precipitação e outras origens de recarga, e a natureza da cidade.

Muitas fontes de recarga são estáveis, ou têm flutuações aleatórias não relacionadas à precipitação, sendo freqüentemente pequenas, e usuaimente de localização desconhecida. Estes fatores permitem o uso da maioria dos métodos já citados, sendo que as técnicas existentes no método do balanço hídrico são as mais utilizadas. Para reduzir os erros acumulados por cada um dos componentes do balanço do suprimento de água potável e efluentes numa área urbana LERNER (1990) simplificou a estimativa da recarga a:

\section{recarga = água importada mais extração local de água subterrânea menos consumo menos efluentes que deixam a área.}

Técnicas de estimativas dos componentes de entrada (suprimento de água potável), saídas (esgotos) e outros componentes, que devem ser consideradas em grandes comunidades, discutidas por aquele autor estão abreviadas a seguir:

\section{Perdas da rede de distribuicão:}

Como as perdas não podem ser medidas diretamente, duas práticas são comumente adotadas:

1) vazamentos $=L \times$ suprimento. Onde: $L=$ indice de perda física em relação ao suprimento de água (valores de $L$ entre $10-60 \%$ têm sido registradas)

2) vazamentos $=$ suprimento menos consumo

A primeira equação é mais fácil de ser aplicada, mas introduz maiores erros, sendo que a precisão dependerá de L. A utilização da segunda equação depende de como o consumo da água é medido na cidade e do periodo de tempo escolhido (dia, més, ano).

\section{Perdas nas ligacões domésticas}

Estas perdas estão relacionadas aos vazamentos ocorridos nos tubos conectados entre os domicilios e a rede de distribuição, sendo que estes constituem, freqüentemente, as maiores perdas dos sistemas de distribuição de água.

\section{Tanques sépticos}


Pode ser assumido que a recarga devida às infiltrações das águas servidas corresponde ao total de água que os tanques sépticos recebem, ou igual ao total de suprimento menos o consumo, se estes forem apenas os principais dispositivos de despejo destas águas.

\section{Redes de esgoto}

E difícil estimar as perdas pelas redes de esgotos, podendo ser desconhecidos os detalhes construtivos das tubulações, das junções e das propriedades dos solos. Podem ocorrer perdas a partir das redes de esgoto, quando o nivel d'agua está abaixo das tubulações, e pode haver entradas, na situação inversa, sendo que estas entradas e saidas são raramente medidas. Entradas relativamente altas são apresentadas por HANNIGAN (1984) que cita a taxa de $9 \mathrm{~m}^{3} /$ dia, para uma tubulação de $450 \mathrm{~mm}$ de diâmetro. Em um estudo realizado em 1984 pela Universidade de Birmingham in LERNER (1990), foi demonstrado que as perdas verificadas pelas redes de esgotos foram aproximadamente iguais às perdas das redes de distribuição de água.

Uma opinião é a de que as perdas são baixas devido ao fato destas tubulações encontrarem-se geralmente não pressurizadas (LERNER,1986), mas não há ainda evidências para esta afirmação.

\section{Percolação profunda a partir da irrigação}

A irrigação de parques e jardins normalmente é feita por pessoas não especializadas, provocando excedentes de água percolam no solo e tornam-se recarga.

Os métodos de estimativa desta origem de recarga guardam similaridades com a recarga da precipitação direta (medidas diretas, balanço hídrico, aproximações darcinianas e traçadores artificiais).

\section{Captacão de telhados}

Dispositivos para captações e reservas de grandes volumes de água escoadas de telhados são largamente utilizados principalmente em ilhas. Se nestes locais existem tanques sépticos o uso de tais dispositivos aumentam a recarga porque o consumo de água será maior do que a evapotranspiração que deveria ocorrer. Um exemplo típico é o estudo de THOMSON (1986) nas lithas de Bermudas.

Outras origens de recarga urbana incluem:

Recarga direta - há circunstâncias em que a recarga direta na área urbana é aumentada e não reduzida com a urbanização. Alguns trabalhos (VAN DAM (1984), GENZ (1995)), mostram que superficies cobertas com paralelepipedos e bloquetes são notavelmente permeáveis, além de reduzirem a evaporação. 
Recarga por aumento dos fluxos subterrâneos a partir do aumento dos fluxos das águas superficiais - fluxos de rios podem ser aumentados pelo runoff e pela descarga de efluentes.

Recarga de bacias de retenção do escoamento superficial - diversos métodos de estimativa de recarga peias bacias de retenção são encontrados em textos clássicos (por exemplo HALL (1984)).

Recarga de efluentes - os efluentes das cidades podem ser dispostos em lagoas especiais, descarregados em rios, espalhados ou aspergidos, ou excepcionalmente lançados em poços. Nestes casos, a estimativa da recarga pode ser feita pelo método do balanço hídrico, darcinianos e de traçadores.

\subsubsection{Exemplos de estudos realizados}

Dois importantes estudos merecem destaque por terem sido realizados especificamente em áreas urbanas, sendo um em região de clima semi-árido, na cidade de Lima (Perú), e outro sob clima úmido, nas llhas de Bermudas.

O estudo realizado em Lima por LERNER (1986), abrangeu um aqüifero aluvial de 400 $\mathrm{km}^{2}$ de extensão e $600 \mathrm{~m}$ de espessura, sendo que metade desta área encontrava-se urbanizada, e o restante era destinada a atividades agrícolas. Nesta região a recarga é realizada direta e indiretamente por dois rios principais (perda direta do rio, irrigação na agricultura e parques, e perdas na rede de distribuição de água potável)

Métodos do balanço hídrico foram usados para estimar as várias parcelas da recargas e posteriormente foram refinados, por calibração, num modelo de fluxo de água subterrânea, sendo que a perda pela rede de distribuição obteve maior ênfase naquele estudo. Esta foi estimada por: (a) teste do MNF (Minimum Night Flow), que se constitui num procedimento padrão usado para detectar vazamentos; (b) estimativa do consumo real; $\quad$ (c) análise dos registros de medição para distinguir as perdas do sistema e das ligações domiciliares.

O estudo mostrou que $50 \%$ do suprimento de água é perdido por vários tipos de fuga. Cerca de $40 \%$ da adução se torna recarga (35\% das adutoras e $5 \%$ das ligações domiciliares). Maiores detalhes são encontrados em WILD (1987).

O outro estudo foi realizado nas llhas de Bermudas por THOMSON (1986) onde a precipitação média é de $1460 \mathrm{~mm} / \mathrm{ano}$, e onde existe um sistema de suprimento de água feito pela captação de chuvas dos telhados de quase todas as residências. Apenas $8 \%$ das casas possuem rede de esgotos, sendo que os restantes lançam as águas servidas em fossas. Mais de 150 poços extraem $4.500 \mathrm{~m}^{3} / \mathrm{d}$ para abastecimento comercial e público. 
Foi estimado que $75 \%$ da chuva é evaporada, resultando numa recarga direta de 365 $\mathrm{mm} / \mathrm{ano}$ sobre as áreas com vegetação. A recarga total encontrada foi entre $410-740$ $\mathrm{mm} / \mathrm{ano}$, que representa mais de duas vezes a recarga direta.

Outros estudos não aplicados em áreas urbanas são também apresentados:

Um importante estudo de recarga em terreno tipicamente laterítico em Kerda (Índia) foi apresentado por LANGSHOLT (1992), utilizando-se de medições de parâmetros hidrológicos (precipitação, runoff, umidade do solo e níveis d'água) durante duas estações quentes, em uma área piloto de $600 \mathrm{~m}^{2}$, e cuja precipitação varia entre 2000 e $4000 \mathrm{~mm}$. $O$ estudo demonstrou que $60-70 \%$ da precipitação torna-se recarga e que o tempo de resposta do nível d'água a um evento de precipitação foi de aproximadamente 10 horas, enquanto as velocidades da zona não-saturada, deduzida a partir de tensiômetros, foi da ordem de $10 \mathrm{E}-03$ $\mathrm{m} / \mathrm{h}$. A discrepância entre esses resultados foi explicada pela infiltração através de caminhos preferenciais que cortam toda a zona insaturada para a franja capilar.

JOHANSSON (1988) apresentou seis métodos de estimativa de recarga direta que foram aplicados em uma área na Suécia (modelo de fluxo unidimensional, modelo hidrológico, umidade do solo, flutuação do nível d'água, concentração do cloro, descarga das nascentes e modelo de área de "captação"). Os resultados obtidos foram muito variáveis, demonstrando a necessidade de se realizar estudos comparativos com vários métodos, visto que todos gozam de substanciais incertezas.

JOHANSSON (1987) utilizou dois métodos para estimativa da recarga, ambos baseados na flutuação hidrostática: (a) modelo de fluxo unidimensional que foi testado contra niveis d'água observados; (b) tansformação direta das flutuações dos níveis de água subterrânea em quantidades equivalentes, a partir da curva de recessão do nível d'água e do conceito de capacidade especifica. O intervalo de medição foi de 14 dias. Os resultados mostraram que o primeiro método pode ser usado para simular flutuações do nível d'água (naquele contexto geológico), entretanto no segundo método, os resultados foram relativamente instáveis e muito diferentes para diferentes anos. $O$ autor concluiu ser impossivel adotar um valor constante de capacidade específica.

\subsubsection{Estudos desenvolvidos na Bacia Sedimentar de São Paulo}

Dentre os mais antigos e de maior importância, destaca-se o estudo hidrogeológico, de âmbito regional, executado pelo DAEE (1975), no qual é apresentada uma avaliação da recarga aqüifera para toda a bacia do Alto Tietê $(1460 \mathrm{~km} 2)$, baseado em dados de balanço hidrológico. Foi encontrada uma contribuição subterrânea de $62 \%$, o equivalente a uma lâmina de $355 \mathrm{~mm} / \mathrm{ano}$ por toda a área ou $661 \mathrm{~mm} / \mathrm{ano}$ considerando-se somente as áreas permeáveis. 
Mais recentemente quatro estudos hidrogeológicos, sendo um a nivel regional e os demais a nivel local, apresentaram valores de estimativas de recarga no contexto da área da Bacia sedimentar de São Paulo.

O estudo de abrangência regional foi executado pelo Centro de Pesquisas de Águas Subterrâneas (SABESP/CEPAS-IG-USP, 1994) na Região Metropolitana de São Paulo (RMSP). Adotando-se a lâmina de infiltração de $355 \mathrm{~mm} / a n$ encontrado pelo DAEE (1975), foi estimada, neste estudo, uma recarga reguladora para toda a Bacia Sedimentar de São Paulo, da ordem de $898 \mathrm{Mm}^{3} / a n o$ ( $42 \%$ deste total, ou seja, $383 \mathrm{Mm}^{3} / a n o$, seriam correspondentes às recargas induzidas pelos vazamentos da rede de distribuição de água).

Dentre os estudos de caráter local, o primeiro foi realizado por SZIKSZAY (1987), visando a investigar a dinâmica e evolução química da água na zona não-saturada, até, inclusive, o aqüífero, bem como o estudo do efeito da evaporação e infiltração da água na zona insaturada. Foi instalada uma estação experimental com dimensão de $10 \times 11$ metros dentro do viveiro de plantas da Cidade Universitária, cuja litologia compreende estratos arenosos e argilosos da Formação São Paulo.

A condutividade hidráulica, obtida a partir de amostras indeformadas a até 4 metros de profundidade, na zona não-saturada, variaram de $3,7 \times 10^{-3} \mathrm{~cm} / \mathrm{s}$ para camadas arenosas a $8,4 \times 10^{-6} \mathrm{~cm} / \mathrm{s}$ para camadas argilosas, com uma média de $1,45 \times 10^{-4} \mathrm{~cm} / \mathrm{s}$. Para a zona aqülfera obteve-se condutividade hidráulica de $1,1 \times 10^{-4} \mathrm{~cm} / \mathrm{s}$ a $1,8 \times 10^{-4} \mathrm{~cm} / \mathrm{s}$.

A observação do nivel hidrostático/g/ 9 e monitoramento para controle do movimento vertical da água (com uso de tensiômetros) foram semanais, por um período de 28 meses. A infiltração se deu num período de 50 a 170 dias, com maiores valores de Janeiro a Abril (estação chuvosa), indicando a recarga do aqüifero (SZIKSZAY, 1987). A superficie de evaporação situou-se a uma profundidade de 0,5 a 1,5 metros.

O estudo seguinte foi realizado por IRITANI (1993), para avaliação do Potencial hidrogeológico da Cidadade Universitária de São Paulo $\left(4,3 \mathrm{~km}^{2}\right)$, cujas litologias são representadas por sedimentos terciários (argilas, areias e cascaihos), aluviōes quaternários e rochas do embasamento cristalino (migmatitos). O estudo se concentrou no aqüifero sedimentar, cuja espessura é de 50 metros em média, para uma parte da área $\left(1,19 \mathrm{~km}^{2}\right)$ do aqüifero livre a semi-confinado, a 15 metros em média para a outra parte $\left(2,4 \mathrm{~km}^{2}\right)$ do aqüifero livre. Os aluviões apresentaram espessuras da ordem de 2 metros.

O cálculo da condutividade hidráulica do aqüífero foi efetuado a partir de ensaio de aqüifero, em um poço produtor, obtendo-se valores da ordem de $10^{-6}$ a $10^{-4} \mathrm{~cm} / \mathrm{s}$ para todo 0 pacote sedimentar, com uma média da ordem de $10^{-5} \mathrm{~cm} / \mathrm{s}$.

Foram monitorados durante 21 meses os níveis d'água de 11 poços de observação com profundidades em torno de 30 metros e de 3 poços multiniveis. Os resultados apresentaram variações dos niveis d'água de 0,6 a 3,0 metros, sendo que as maiores 
elevações ocorreream nos meses de Janeiro a Maio, época de chuvas, enquanto os níveis mais baixos foram atingidos de Dezembro a Março, durante a estiagem.

A taxa de recarga específica foi estimada a partir do cáculo da reserva reguladora $\left(913.063 \mathrm{~m}^{3} / \mathrm{ano}\right)$, em relação à área do aqüifero $\left(3,59 \mathrm{~km}^{2}\right)$, tendo sido encontrado um valor médio de 0,25 milhöes $\mathrm{m}^{3} / \mathrm{km}^{2} / a n o$.

\subsection{MÉTODOS APLICADOS À ANÁLISE DO ESCOAMENTO SUPERFICIAL}

\section{URBANO}

A avaliação criteriosa do escoamento superficial inclui a determinação da vazão de pico, do volume e da forma do hidrograma, bem como do periodo de retorno associado a esses valores PORTO (1995). Os valores obtidos serão sempre aproximados, devido às incertezas hidrológicas, às simplificações dos métodos e aos critérios adotados.

A determinação da chuva excedente (ou efetiva, ou escoamento superficial direto) pode ser feita a partir de duas abordagens (PORTO,1995):

1) relações funcionais que consideram o total precipitado, o tipo de solo, sua ocupacão, a umidade antecedente, etc.. Exemplos de métodos incluem os consagrados método do número da curva do Soil Conservation Soil (SCS) e o método do coeficiente de escoamento superficial, este utilizado para cálculo das vazões de pico no método racional.

2) métodos baseados na diferença entre a precipitação e as perdas por infiltração, interceptação, retenção e outras. Tais métodos baseiam-se em equaçōes de infiltração, citando-se como mais correntemente aplicadas, em ordem decrescente de rigor teórico: as de Horton, a de Green Ampt, método do SCS e método do índice Fi.

Basicamente existem dois métodos consagrados mundialmente na avaliação do escoamento superficial direto: o Método Racional e os vários métodos baseados na teoria do Hidrograma Unitário (Método de Clark. Hidrograma Triangular, Hidrograma Sintético do SCS, Hidrograma sintético do CHUP - Colorado Urban Hydrograph Procedure).

Nos dois métodos a vazão de projeto e o hidrograma de cheias são determinados a partir de uma chuva de projeto, da qual são descontadas as diversas perdas que ocorrem na bacia (PORTO, 1995). Os campos de aplicação e restrições ao uso destes métodos são sintetizados a seguir, entretanto os detalhes dos procedimentos não serão aqui abordados devido à sua extensão, sendo entretanto largamente disponiveis na literatura, citando-se, a nivel nacional: TUCCI (1993); TUCCI (1995) e CETESB (1980).

Método Racional - é recomendado para determinação de vazões de pico em pequenas bacias (entre 1 e $3 \mathrm{~km}^{2}$ ), ou que tenham tempo de concentração menor do que uma 
hora. (PORTO, 1995). A hipótese central do método é que a duração da chuva é igual ao tempo de concentração da bacia. $O$ método é definido pela seguinte expressão:

$Q p=0,275$ C.I.A

onde:

$Q p=$ vazão de pico $\left(\mathrm{m}^{3} / \mathrm{s}\right)$;

$\mathrm{C}=$ coeficiente do escoamento superficial (adimensional, relacionado com a chuva efetiva e

com os efeitos de armazenamento);

$\mathrm{I}=$ Intensidade média da chuva em $\mathrm{mm} / \mathrm{h}$, considerada constante;

$A=$ área da bacia $\left(\mathrm{km}^{2}\right)$.

Se os efeitos do armazenamento são despreziveis (o que seria razoável supor-se em bacias urbanas pequenas), $\mathrm{C}$ é denominado de coeficiente de escoamento superficial; e o pico de chuva ocorre no instante em que a chuva cessa.

Métodos baseados na Teoria do Hidrograma Unitário (PORTO, 1995) - são empregados em bacias maiores que $3 \mathrm{~km}^{2}$, não sendo mais possivel admitir-se a hipótese de intensidade constante da chuva ao longo da sua duração nem a inexistência de armazenamento na bacia.

Hidrograma unitário é o hidrograma produzido por uma unidade de chuva excedente $\left(h_{\text {exc }}\right)$ distribuída uniformemente sobre a bacia, com duração especificada $\left(h_{u n i t}=10 \mathrm{~mm}\right)$, sendo que a duração dessa chuva poderá ser qualquer, desde que permita o traçado adequado dos trechos de ascensão e decaimento do hidrograma. De posse de um hidrograma unitário de uma determinada duração, obtêm-se hidrogramas unitários para quaisquer durações, seja por meio de superposições de hidrogramas de menor duração, seja pela solução de um sistema de equações lineares.

Os hidrogramas unitários de uma bacia podem ser determinados: (1) pela análise de dados de precipitação e vazão, ou (2) por meio de fórmulas empíricas (hidrogramas sintéticos), quando não se dispõe destes dados. Estes hidrogramas sintéticos determinam a forma do hidrograma, a vazão de pico a partir de parâmetros relacionados com as características físicas da bacia, e geralmente representam o hidrograma na forma de um triângulo.

\subsubsection{Medidas alternativas para o controle de enchentes}

As medidas para controle de enchentes podem ser classificadas de acordo com a sua natureza em estruturais e não-estruturais.

As medidas estruturais estäo relacionadas às obras visando a correção ou a prevenção dos problemas decorrentes das enchentes, tais como modificações dos rios, construção de reservatórios a jusante, construção de polders, e outras. Criam uma falsa sensação de segurança, permitindo a ocupação de áreas inundáveis (TUCCl, 1993). 
As medidas-não estruturais são de caráter extensivo, com ações abrangendo toda a bacia, ou de natureza institucional, administrativa ou financeira, adotadas espontaneamente ou por força da legislação, destinadas a atenuar os deflúvios ou a orientar os ocupantes das áreas potencialmente inundáveis, no sentido de conviverem com a ocorrência periódica do fenômeno (DAEE, 1989).

TUCCl (1995) classifica as medidas de controle do escoamento de acordo com sua ação na bacia hidrográfica, em:

- distribuidos ou na fonte: controle que atua sobre o lote, praças e passeios;

- na microdrenagem: controle que age sobre o hidrograma resultante de um ou mais loteamentos;

- na macrodrenagem: controle sobre os principais córregos urbanos.

\section{Medidas de controle distribuido ou na fonte (source control)}

As medidas de controle na fonte referem-se a obras e dispositivos construídos junto aos domicílios, de forma a reter os escoamentos, promovendo a redução do pico das enchentes, por meio de sistemas de infiltração e percolação, ou pelo armazenamento temporário dos escoamentos em reservatórios. A recarga de aqüiferos e a utilização das águas armazenadas podem ser as outras finalidades de tais dispositivos (CANHOLI, 1995).

\section{Sistemas de Infiltração e Percolação}

Vários são os dispositivos utilizados, citando-se como mais importantes: planos e valos de infiltração, bacias de percolação, dispositivos hidráulicos (FUJiTA, 1984), pavimentos permeáveis (GENZ (1995); JACOBSEN (1981); FUJITA (1984), HOGLAND (1986)).

No estudo de MUSIAKE (1994), o autor discute os efeitos dos vários sistemas de infiltração subsuperficial (galerias e caixas de conexão) sobre a redução da inundação, com base em observação e experimentos numa área piloto, no Japão. Mostrou-se, pela grande redução dos volumes dos escoamentos em todas as intensidades de precipitação, que tal sistema é bastante efetivo se usado em conjunto com outras medidas de retenção.

\section{Sistemas de Armazenamento}

Os sistemas de armazenamento destinam-se à reservação temporária da água pluvial, provocando uma distribuição dos volumes e da vazão no tempo. Estes sistemas têm sido adotados em diversos países citando-se o Japão, tal como apresentado por YOSHIMOTO, SUETSUGI (1990) que relatam a construção de cerca de 500 reservatórios de retencão de 1,3 $\mathrm{m}^{3}$ na bacia do rio Tsurumi, Japão. 
GENZ, TUCCl (1995) mostraram que se pode obter uma redução na vazão de escoamento a niveis inferiores ou iguais à vazão anterior à ocupação do lote. Os autores analisaram por simulação, os efeitos do armazenamento temporário em microrreservatórios sobre o escoamento superficial em um lote urbano, na cidade de Porto Alegre (RS). Discutiuse ainda nesse estudo: as formas construtivas dos microreservatórios, em função da sua eficácia na reservação e escoamento; os locais de instalação (nos telhados ou na saída dos lotes); os diversos resultados obtidos para vários protótipos de ocupacão do lote, com variações nas taxas de impermeabilização.

SHILLING (1982) apresentou um microrreservatório conectado com o tubo de queda do telhado, com duas saídas tubulares na vertical, uma no fundo, com diâmetro reduzido e a outra na parte superior da caixa, conseguindo uma redução máxima possível na vazão de pico de $42 \%$.

Cabe citar ainda os reservatórios destinados à captação das águas pluviais dos telhados para fins de abastecimento doméstico nas ilhas Bermudas (LERNER, 1990), que terminam por diminuir o pico dos escoamentos, além de favorecer também a recarga aqüifera, já que apenas $8 \%$ das casas possuem rede de esgotos.

De acordo com URBONAS (1993), as principais características do controle local do escoamento são: (a) aumento da eficiência do sistema de drenagem de jusante dos locais controlados; (b) aumento da capacidade de controle das enchentes dos sistemas; (c) dificuldade de controlar, projetar e fazer manutenção de um grande número de sistemas; (d) os custos de operação e manutenção podem ser altos.

\section{Medidas de controle na microdrenagem}

O escoamento conduzido pelas obras de drenagem até um coletor principal ou córrego urbano transferem o aumento do escoamento superficial para jusante, com maior velocidade, provocando inundações nos troncos principais ou na macrodrenagem.

O amortecimento do volume gerado pode ser realizado através de dispositivos como: tanques, lagos e pequenos reservatórios abertos ou enterrados, etc.

\section{Medidas de controle na macrodrenagem}

As principais medidas estruturais de controle de enchentes são: canalização dos rios, construção de reservatórios de amortecimento e diques em combinação com polders. Medidas não estruturais envolvem o zoneamento de áreas de inundações, através da regulamentação do uso do solo com risco de inundação, ocupação com áreas de lazer, seguros contra inundações, dentre outras (TUCCl (1995); DAEE (1989)). 


\section{QUADRO GEOLÓGICO E HIDROGEOLÓGICO REGIONAL}

\subsection{CONTEXTO GEOLÓGICO-TECTÔNICO}

A área de estudos está situada na Bacia Sedimentar de São Paulo, de idade terciária, a qual faz parte de um sistema de bacias tafrogênicas continentais, de idade cenozóica, integrantes do chamado "Rift Continental do Sudeste do Brasil" (RICCOMINI, 1989).

Aos processos de rifteamento está associado desenvolvimento das bacias sedimentares do Alto Paraná, bacias costeiras como a de Santos, e as bacias tafrogênicas continentais, como as de São Paulo, Curitiba, Taubaté, Resende e Volta Redonda (ALMEIDA, 1976). O desenvolvimento destas bacias corresponderia à etapa tardia desse processo tectônico, segundo ASMUS (1979).

As rochas pré-cambrianas do embasamento destas bacias são essencialmente metamórficas (milonito-gnaisses, milonitos, blastomilonitos, gnaisses bandados, gnaisses graníticos, xistos, quartzitos e anfibolitos bandados), migmatitos, granitos, pegmatitos e aplitos (RICCOMINI,1987).

Os sedimentos terciários que recobrem as rochas cristalinas do embasamento, constituem o Grupo Taubaté, que engloba as Formaçōes Resende, São Paulo, Tremembé e Itaquaquecetuba (MELO (1989); RICCOMINI (1992)).

\subsection{A BACIA SEDIMENTAR DE SÃO PAULO}

A Bacia sedimentar de São Paulo está geomorfologicamente localizada no Planalto Paulistano (ALMEIDA, 1958), de relevo suavizado, com morros e espigões relativamente baixos, predominando altitudes entre 715 - 900 metros. A drenagem flui para o rio Tieté e seus afluentes, a montante da soleira de Barueri, sendo os principais, os rios Pinheiros, Tamanduateí e Aricanduva.

A forma da bacia é aproximadamente elíptica, com eixo maior de $75 \mathrm{~km}$, e eixo menor de $25 \mathrm{~km}$, compreendendo os terrenos pré-cambrianos, os sedimentos terciários e as coberturas colúvio-aluviais quaternárias (Figura 5 ). Os sedimentos terciários estendem-se por aproximadamente $1.000 \mathrm{~km}^{2}$, sendo de distribuição bastante irregular (RICCOMINI,1992).

A bacia é um hemi-graben basculado para NNW, com variáveis espessuras dos sedimentos; as quais foram controladas pelo páleo relevo do embasamento cristalino e pela subsidência induzida por tectonismo (HASUI, 1980). A espessura máxima contínua de sedimentos registrado no corpo principal da bacia é de 256 metros, no Bairro da Mod́ca (TAKYIA, 1991). 


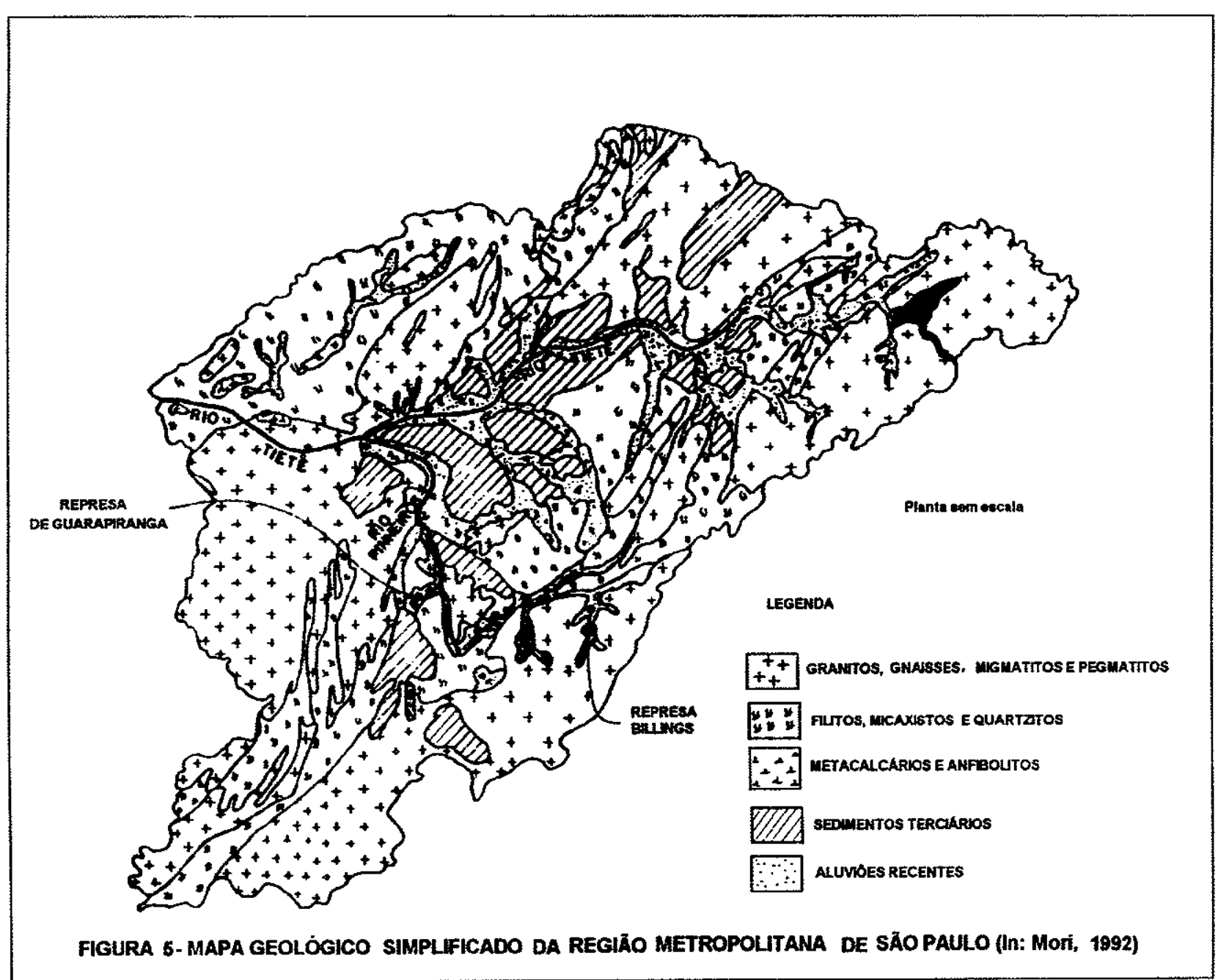




\subsubsection{Embasamento Pré-cambriano}

As rochas do embasamento cristalino sob a Bacia de São Paulo são consideradas como pertencentes ao Grupo Açungui, de MARINI (1967), In: PRÓ-MINÉRIO/IPT (1981), de idade do Proterozóico Superior, constituindo a mais extensa unidade do Pré-cambriano paulista. Por vezes as rochas do embasamento chegam a se expor em janelas na área da bacia, como verificado em Campos Eliseos, Pacaembu e Sumaré (COUTINHO, 1972), neste último local, dentro da área deste estudo.

\subsubsection{Sedimentos Terciários}

Os sedimentos continentais terciários da Bacia de São Paulo são de natureza síltica argilosa com intercalações lenticulares de areia. Predominantemente fluviais e localmente lacustres, foram depositados sob condições áridas e transportados a curta distáncia, com baixa disponibilidade de água no ambiente (WERNICK, 1966; SUGUIO et. alii., 1972, In: SUGUIO, 1980).

Tais sedimentos foram designados de Formação São Paulo por MEZZALIRA (1962), In: RICCOMINI et. alii. (1992), que englobaria leques aluviais lamosos, associados à borda tectonicamente ativa da bacia, gradando para drenagem em rios entrelaçados (braided) depósitos de sistema fluvial meandrantre, além de fácies lacustre efêmera e localizada (MELO et. al., 1989, In: RICCOMINI et alii, 1992).

Mais recentemente, RICCOMINI (1989) reformulou a litoestratigrafia das Bacia de São Paulo, Taubaté, Volta Redonda e Resende, com base na análise conjunta de fácies e sistemas deposicionais. Esta revisão resultou no seguinte quadro litoestratigráfico para os depósitos sedimentares terciários da Bacia de São Paulo: concepção de duas unidades litoestratigráficas: a) Grupo Taubaté, englobando as Formações Resende, Tremembé e São Paulo, e b) Fm. Itaquaquecetuba, esta considerada pelo autor como mais jovem que a $\mathrm{Fm}$ Săo Paulo.

\subsubsection{Formação Resende}

A Formação Resende é de distribuição generalizada, perfazendo mais de $80 \%$ do preenchimento da bacia, tendo sido reconhecidas duas litofácies principais, as quais englobam depósitos fanglomeráticos (leques aluviais) que gradam para depósitos relacionados à planície aluvial de rios entrelaçados (braided).

A primeira litofácies (membro inferior) é representada pelos depósitos de leques aluviais proximais, encerrando diamictitos e conglomerados com seixos, matacões e blocos 
angulosos e subarredondados, normalmente polimíticos, dispersos em matriz essencialmente lamítica a arenosa. A coloração, no geral, é esverdeada quando não alterada. São gerados por processos de fluxo de detritos (debris flow) e comumente encontram-se associados à borda norte da bacia, tectonicamente ativa à época da deposição destes sedimentos.

A segunda litofácies (membro superior) apresenta-se interdigitada às fácies proximais dos leques aluviais. Trata-se de lamitos associados a arenitos e niveis conglomeráticos de sistema fluvial entrelaçado, predominando nas porções distais dos leques aluviais. Caracterizam-se por apresentar matriz argilo-arenosa abundante, envolvendo na maioria, grânulos a seixos de quartzo e feldspato, de coloração variando em tons avermelhados, amarelados, acinzentados e esverdeados. Encontram-se às vezes intercalados a arenitos e conglomerados maciços ou com estratificação cruzada.

\subsubsection{Formação São Paulo}

A Fm. São Paulo corresponde a depósitos de sistema fluvial meandrante, tendo sido reconhecidas, por RICCOMINI (1989), duas litofácies principais: a primeira litofácies encerra arenitos grossos, conglomeráticos, localmente conglomerados com granodecrescência ascendente para siltitos e argilitos, apresentando espessura métrica dos pacotes. A segunda litofácies encerra arenitos de granulação média a grossa com granodecrescência ascendente para sedimentos arenosos progressivamente mais finos, até siltitos e argilitos. Crostas e concreções (couraças limoníticas) de espessuras variadas são freqüentes na interface entre sedimentos argilosos e arenosos, proporcionando pronunciada impermeabilidade no topo das camadas peliticas (RICCOMINI, 1992).

Estas ocorrências, segundo os autores, seriam responsáveis pelas freqüentes surgências das águas que percorrem os pacotes arenosos, conforme pode ser observado, dentre outros locais, na Av. João Paulo VI (proximidades do viaduto da Rua Oscar Freire), na Av. Sumaré (próximo ao entroncamento da R. Atalaia) e ao lado do Estádio Municipal do Pacaembu (sentido Av. Pacaembu - Av. Dr. Arnaldo).

A melhor exposição desta formação ocorre ao longo do espigão central da cidade, em cotas superiores a 750 - 760 metros, sustentada por couraças ferruginosas, podendo atingir 70 metros de espessura na Av. Paulista. Já na porção oeste da cidade os sedimentos apresentam distribuição altimétrica irregular (RICCOMINI, 1992).

Esta unidade encontra-se estratigraficamente sobreposta ao sistema de leques aluviais da Fm. Resende, particularmente na região oeste da Bacia de São Paulo. 


\subsubsection{Formação Itaquaquecetuba}

Os depósitos da Fm. Itaquaquecetuba correspondem ao sistema fiuvial entrelaçado (braided), ocorrendo sob os sedimentos aluviais holocênicos dos rios Tietê. Pinheiros e Tamanduateí (RICCOMINI, 1992). Sua forma de contato, verificada até o momento, se dá unicamente com as rochas do embasamento.

Na sua área tipo, portos de areia da margem direita do Rio Tietê em Itaquaquecetuba; atinge espessura máxima estimada em torno de 50 metros (COIMBRA, 1983).

RICCOMINI (1989) reconheceu cinco fácies nesta unidade, sendo que a fácies predominante é constituida de arenitos médios a grossos, arcosianos, mal selecionados, com níveis basais de espessura decimétrica de conglomerados de quartzo e quartzito bem arredondados.

\subsubsection{Coberturas Cenozóicas}

Os depósitos neocenozóicos (plio-pleistocênicos) correspondem às associações colúvio-aluviais com 4 a 5 metros de espessura, de distribuiçăo relativamente restrita e que acompanham grosseiramente a topografia. Constituem-se de conglomerado basal, seguido de material argilo-arenoso variegado com seixos dispersos, sendo incluidas também as couraças limoníticas de espessura métrica que ocorrem nos topos de algumas colinas de sedimentos terciários, as quais, segundo RICCOMINI (1992), são de provável idade neocenozóica..

Os depósitos pleistocénicos compreendem predominantemente colúvios argiloarenosos, com lentes mais argilosas ou conglomeráticas, e aluviōes subordinados constituídos por conglomerados basais sobrepostos por areias grossas a conglomeráticas, gradando para areias finas a médias, com porções de argilas arenosas (MELO,1987).

Os depósitos holocênicos são constituídos de coluviöes e aluviōes em várzeas e baixos terraços, com espessura raramente ultrapassando os 10 metros. Os colúvios são de distribuição generalizada, descontínuos e de pequena espessura, sendo separados das rochas do embasamento cristalino ou de sedimentos terciários por cascalheiras (stone lines). Os depósitos aluviais estão presentes nas várzeas, como os depósitos de baixos terraços, ocorrendo cascalheiras nas base destes depósitos com seixos a blocos de quartzo e quartzito.

\subsection{CONTEXTO HIDROGEOLÓGICO}

As duas pequenas sub-bacias hidrográficas deste estudo fazem parte do domínio hidrográfico maior, a Bacia do Alto Tietê, a qual é circundada por setores montanhosos que formam os divisores naturais das águas superficiais e subterrâneas do sistema. 
O curso principal (Rio Tietê) escoa no sentido leste-oeste, atravessando dois grandes sistemas aqüiferos principais: o aqüifero sedimentar da Bacia de São Paulo, de idade terciária, e o aqüífero fraturado pertencente às rochas do substrato cristalino.

A caracterização da recarga aqüifera regional é ainda pouco elucidada devido a diversas interferências impostas pela ocupação urbana e pela própria complexidade do contexto geológico.

De acordo com o modelo conceitual atuaimente adotado (DAEE, 1975; CEPAS/SABESP, 1994) é nas partes mais permeáveis e realçadas do relevo, onde ocorrem os terrenos cristalinos, que se processam as infiltrações naturais mais importantes, cujos fluxos subterrâneos, seriam responsáveis pela alimentação das drenagens e dos pacotes sedimentares, geralmente localizados nos setores topográficos mais deprimidos. É ainda nestes terrenos cristalinos que $61 \%$ da área da RMSP está legalmente protegida (EMPLASA,1993) ou seja, constituem área de recarga efetiva, ressaltando-se que a RMSP $\left(8051 \mathrm{~km}^{2}\right)$ está praticamente inserida na Bacia do Alto Tietê.

Segundo esse modelo, nos setores mais deprimidos do relevo, por onde normalmente se estende o domínio sedimentar, no geral o solo está severamente impermeabilizado pela ocupação urbana. Neste caso a infiltração natural ocorreria nas partes não impermeabilizadas e a redução da recarga direta seria amplamente compensada pelos vazamentos da rede de água, cujo índice foi avaliado em aproximadamente $43 \%$ do total das reservas reguladoras do aqüífero sedimentar.

Cerca de 7.000 poços na RMSP extraem um volume da ordem de $203 \mathrm{Mm}^{3} / a n o$, o que representa apenas cerca de $25 \%$ das disponibilidades avaliadas para toda a RMSP (CEPAS/SABESP, 1994).

\subsubsection{Sistema Cristalino}

O sistema aqüifero cristalino corresponde às rochas do embasamento geológico de idade Pré-Cambriana. É o mais extenso dentro do domínio da RMSP, ocupando um área total de $6.599 \mathrm{~km}^{2}$, compreendendo os diversos tipos petrográficos principais: migmatitos, gnaisses, granitóides, metassiltitos, filitos, anfibolitos, quartzitos, micaxistos e rochas metacarbonáticas.

Um espesso manto de intemperismo e as zonas de fraturas das rochas semialteradas e sãs, compõem o sistema aqüifero cristalino, proporcionando condições de aqüifero livre a semi-livre.

No manto de intemperismo, a espessura média é de 50 metros, podendo local e ocasionalmente atingir 150 metros, e a porosidade efetiva é citada como da ordem de $3 \%$, com base no caráter litológico (SABESP/CEPAS, 1994). As condições hidráulicas são pobres, 
Um espesso manto de intemperismo e as zonas de fraturas das rochas semialteradas e sãs, compõem o sistema aqüifero cristalino, proporcionando condições de aqǘfero livre a semi-livre.

No manto de intemperismo, a espessura média é de 50 metros, podendo local e ocasionalmente atingir 150 metros, e a porosidade efetiva é citada como da ordem de $3 \%$, com base no caráter litológico (SABESP/CEPAS, 1994). As condições hidráulicas são pobres, apresentando coeficientes hidráulicos muito baixos, da ordem de $10^{-6}-10^{-7} \mathrm{~cm} / \mathrm{s}$ no terço superior (REBOUÇAS \& CAVALCANTE, 1987, in REBOUÇAS, 1992), podendo chegar a 10-3 $-10^{-4} \mathrm{~cm} / \mathrm{s}$ na zona de transição rocha alterada - rocha sã fraturada.

\subsubsection{Sistema Sedimentar}

A Bacia Sedimentar de São Paulo possui forma aproximadamente elíptica, com maior eixo na direção E-W, e ramificações laterais importantes, sob o ponto de vista hidrogeológico, que são os grabens Jaguaré, Cumbica e Braz Cubas. Com uma extensão total de $1452 \mathrm{~km}^{2}$, representa cerca de $18 \%$ da RMSP (SABESP/CEPAS, 1994).

As variações das espessuras dos sedimentos refletem a grande irregularidade do topo do substrato cristalino, o qual apresenta várias estruturas do tipo "horst" e "graben" originando sub-bacias e janelas de erosão do embasamento. Tal irregularidade pôde ser denotada quando do esboço da espessura saturada dos sedimentos pelo DAEE (1975), encontrandose desde alguns metros até 140 metros.

A bacia compreende duas unidades aqüiferas, que são os sedimentos terciários e os sedimentos aluvionares quaternários, constituntes das várzeas dos rios principais e tributários menores. Embora os sedimentos quaternários atinjam extensão significativa, sua exploração é bastante limitada devido ao alto risco de poluição. Em estudos regionais, como o realizado pelo DAEE (1975), tanto os sedimentos terciários quanto quaternários são incluídos no sistema aqüífero sedimentar da Bacia de São Paulo, devido à ligação hidráulica entre eles e pela dificuldade em se diferenciar as litologias entre as duas unidades por meio dos dados dos poços.

Os sedimentos terciários constituem a unidade aqüifera principal, cuja litoestratigrafia mais recente, proposta por RICCOMINI (1992), reconhece as três litofácies principais, já discriminadas anteriormente, do topo para a base: (1) Fm. São Paulo; (2) Fm Resende membro superior ; e (3) Fm. Resende - membro inferior.

A Fm. Resende possui distribuição generalizada, compreendendo mais de $80 \%$ do preenchimento da bacia, constituindo o seu principal reservatório (SABESP/CEPAS, 1994). 
Esta seqüencia sedimentar foi adotada pela primeira vez, em estudo hidrogeológico, na cartografia do projeto executado por meio do convênio SABESP/CEPAS (1994), em escala 1:50.000, envolvendo toda a RMSP. Até então os sedimentos eram reunidos na Fm. São Pauio, e definidos como um pacote constituido de camadas arenosas e argilosas, com predomínio das segundas. Naquele estudo foi avaliada a tendência das potencialidades hidrogeológicas com base nas características faciológicas dominantes, com a ressalva de tratar-se de uma avaliação bastante genérica, pois é grande a heterogeneidade do meio aqüífero considerado. Assim, a Fm. São Paulo e o membro inferior da Fm. Resende foram apontadas como de tendência alta, enquanto o membro superior da Fm. Resende, de tendência média, devido à predominância de lamitos arenosos a argilosos.

O aqüifero é caracteristicamente heterogêneo e anisotrópico, apresentando-se ora sob condições livres, ora de semi-confinamento. Isto se deve graças à forma de ocorrência das lentes e ou camadas constituintes das unidades faciológicas, que se dispõem em freqüentes intercalações e ou interdigitações, predominando ora os sedimentos arenosos, ora argilosos.

$\mathrm{Em}$ termos de produtividade, os poços perfurados nos terrenos sedimentares apresentam capacidade especifica média de $1,6 \mathrm{~m}^{3} / \mathrm{h} . \mathrm{m}$ (SABESP/CEPAS, 1994). A porosidade efetiva estimada com base na análise do caráter faciológico oscila entre 2 e $10 \%$ (DAEE, 1975), indicando condições de aqüífero livre. Os testes de bombeamento realizados no campus da Cidade Universitária (IRITANI, 1992) indicaram valores de condutividade hidráulica entre $3 E-03$ e $7 E-07 \mathrm{~cm} / \mathrm{s}$. Os valores dos coeficientes de transmissividade variam entre $2 \mathrm{E}-04$ e $8 \mathrm{E}-08 \mathrm{~m}^{2} / \mathrm{s}$, com média em torno de $6 \mathrm{E}-04 \mathrm{~m}^{2} / \mathrm{s}$.

As demais formações reconhecidas por RICCOMINI (1992) são as Formações Tremembé e Itaquaquecetuba. A primeira, essencialmente argilosa e de ocorrência muito limitada não é de interesse hidrogeológico, mas a Fm. Itaquaquecetuba, embora de ocorrência local e bastante limitada, possui boas possibilidades aqüiferas em razão dos litotipos arenosa e espessura considerável; a exemplo do demonstrado em estudo hidrogeológico realizado no campus da Cidade Universitária por IRITANI (1993). 


\section{MATERIAIS E MÉTODOS}

Os materiais utilizados nas etapas de campo e laboratório são apresentados em conjunto com os métodos de desenvolvimento da pesquisa. As diversas atividades envolvidas foram agrupadas em três modalidades, detalhadas a seguir: levantamentos de dados, atividades de campo e atividades de laboratório.

\subsection{LEVANTAMENTOS DE DADOS}

Os levantamentos de dados referem-se à obtenção dos seguintes dados básicos, por meio de documentos existentes, para realização do estudo:

\subsubsection{Bibliografia}

No levantamento bibliográfico estão incluídos, o acervo de trabalhos levantados na literatura nacional e internacional a respeito do assunto da pesquisa, os estudos geológicos e hidrogeológicos da região em questão, bem como os mapas topográficos, fotografias aéreas e de infra-estrutura da área.

\subsubsection{Infraestrutura da área}

Os dados de infraestrutura referem-se ao levantamento, junto à PMSP (AR-LA), do traçado das obras existentes no subsolo - galerias de águas pluviais (GAP's) e canalizações dos córregos principais - e junto à SABESP, da rede de distribuição de água, de onde foram obtidos os setores de abastecimento envolvidos e os indices de perdas mensais, por setor.

\subsubsection{Perdas na rede de distribuição de água}

Os índices mensais de perdas físicas (vazamentos) da rede de distribuição de água durante o período de 1994/1995 foram obtidos junto à SABESP, permitindo-se assim, estimarse o valor da principal contribuição.indireta.

\subsubsection{Nascentes}

Foram cadastradas oito (08) nascentes, das quais apenas três apresentaram-se confiáveis, por apresentarem um bom sistema de captação, com possibilidades mínimas de sofrerem interferência antrópica no parâmetro de vazão e qualidade química das águas. 


\subsubsection{Poços profundos}

Os poços profundos foram cadastrados junto a seis empresas perfuradoras, nas quais foram obtidos dados sobre o perfil litológico, características construtivas e parâmetros hidrodinâmicos (vazão e capacidade específica). Tais dados contribuíram para o esclarecimento das caracteristicas litológicas, produtividade e espessura dos aqüiferos locais. Foram cadastrados 28 poços, sendo que $17(60,7 \%)$ encontram-se ativos e $11(39,3 \%)$ desativados.

\subsubsection{Sondagens "SPT"}

Foram cadastradas 51 sondagens do tipo "SPT" (Standard Penetration Test) dentro dos limites da área, para atender a dois objetivos: melhor caracterização litológica a uma profundidade maior que a atingida pelos poços de monitoramento, que foi de, no máximo, 12 metros; e obtenção de um maior número de pontos d'água para melhor representação espacial do nivel potenciométrico. As profundidades atingidas pelas sondagens variaram de 13 a $34 \mathrm{~m}$.

\subsubsection{Dados meteorológicos}

Para a realização do balanço hídrico climático e caracterização climática de uma forma geral, foram levantados nos arredores e dentro da área, dados diários de três postos controlados pelo Departamento de Águas e Energia Elética do Estado de São Paulo (DAEE) para o periodo de 1980 e 1992. Os postos situados nos arredores da área são o da Lapa (E3010) e Ponte Pequena (E3-096) e o situado dentro da área, o Posto Água Branca (E3-003), (Figura 1).

Os dados de temperatura diária foram fornecidos pela Estação Meteorológica Mirante de Santana (Estação 83781 ), a mais próxima da área (10 km aproximadamente) controlada pelo Instituto Nacional de Meteorologia (INMET).

\subsection{ATIVIDADES DE CAMPO}

As atividades de campo compreenderam os trabalhos de reconhecimento e coleta de dados geológicos, a construção dos poços de monitoramento, a execução de ensaios de permeabilidade, a coleta de amostras de água e solo, e as atividades de monitoramento das nascentes e poços. 


\subsubsection{Construção dos poços de monitoramento}

Foram perfurados 13 poços de monitoramento para acompanhamento das oscilações sazonais do nivel do nivel freático.

A distribuição espacial dos poços foi estreitamente condicionada aos seguintes fatores:

- existência de áreas livres da impermeabilização;

- locais desprovidos de edificações e muros de divisa, por favorecem o acesso de veículos e equipamentos de perfuração e monitoramento;

- priorização das áreas públicas devido à maior facilidade de autorização para a perfuração, e

- restrição às áreas de declive não muito acentuados (> $45 \%$ ) pela impossibilidade do manejo do trado manual.

Considerados os fatores limitantes acima citados, na escolha dos locais para construção dos poços, estes foram assim distribuidos: apenas dois poços foram perfurados em área particular e os onze restantes em praças públicas e áreas municipais livres, tais como balöes de retorno e canteiros centrais. No contexto físiográfico, três estão localizados sobre divisores de água (Poços $n^{\text {os }} 3,5$ e 13) quatro em fundos de vale (Poços $n^{\text {os }} 9,10,11,12$ ), dois ao longo de encostas (Poços $n^{\text {os }} 6$ e 8) e quatro na várzea (Poços $n^{\text {os }} 1,2,4$ e 7 ), apresentados na Figura 6.

Seis poços situam-se na sub-bacia Sumaré e sete na sub-bacia Pompéia. Sob o aspecto geológico, quatro poços localizam-se nos sedimentos quaternários, no domínio das várzeas do Rio Tietê (Poços nos 1, 2, 4 e 7) e os demais no domínio dos sedimentos terciários.

A perfuração dos poços de monitoramento foi executada a trado manual do tipo concha, de 4" de diâmetro. Os furos foram revestidos com tubo de PVC, de 3 " de diâmetro, sendo o fundo e a boca do tubo tapados com "caps" de PVC. Na parte inferior, o tubo foi perfurado por uma extensão de $1 \mathrm{~m}$ e revestido com uma tela de nylon constituindo assim a seção filtrante. O pré-filtro utilizado foi areia lavada, a qual foi colocada de modo que sua espessura superasse a espessura saturada do poço, assegurando-se, desta forma, um aumento da espessura da zona de contribuição. Para proteger e isolar essa seção filtrante, foi adicionado um selo de material argiloso, proveniente da própria perfuração, colocado logo acima do topo da camada de pré-filtro numa seção longitudinal de cerca de $1 \mathrm{~m}$ (Anexo1).

A proteção sanitária dos poços foi constituída de dois compartimentos: uma escavação de forma cilíndrica ao redor do poço, de aproximadamente $40 \mathrm{~cm}$ de altura e $30 \mathrm{~cm}$ de diâmetro, preenchida com argamassa de cimento; e de uma laje construída por cimentação de $5 \mathrm{~cm}$ de espessura abaixo e $5 \mathrm{~cm}$ acima do nível do terreno, numa seção de $50 \times 50 \mathrm{~cm}$. 
Para maior proteção do tubo de revestimento, foi cravada, junto ao cilindro cimentado. uma caixa padrão, em aço, de formato prismático e seção quadrada (comprimento: $60 \mathrm{~cm}$ e seção $12 \times 12 \mathrm{~cm}$ ), cuja tampa foi fechada a cadeado.

As profundidades dos poços foram definidas em função dos niveis d'água durante a perfuração. Após atingido o nível freático, a perfuração prosseguiu por mais um metro, no mínimo, para aumentar a seção de entrada d'água no poço, assegurando-se a leitura na estação seca. Apenas os poços 4 e 5 apresentaram, respectivamente, espessura saturada, com 0,9 e 0,7 m, devido, no primeiro caso, a problemas de desmoronamentos no fundo do poço, e, no segundo, devido à presença de material duro que impediu a continuidade da perfuração. Nos demais onze poços estas variaram entre 1,0 e $2,7 \mathrm{~m}$.

Terminada a execução dos poços, procedeu-se à lavagem interna dos mesmos, por injeção de água sob pressão, através de uma mangueira de "carro pipa" introduzida no fundo do poço, tendo a lavagem prosseguido até que a água de retorno se apresentasse limpa. Tal processo permitiu a expulsão de material fino que havia penetrado após a perfuração.

\subsubsection{Coleta de amostras de solo para caracterização granulométrica}

Durante a perfuração dos poços de monitoramento, foi realizada a descrição táctilvisual granulométrica e textural do solo e retiradas 50 amostras para realização de ensaio granulométrico em laboratório do Departamento Paleontologia e Estratigrafia (DPE-IG/USP).

\subsubsection{Execução dos Ensaios de Permeabilidade in situ}

$\mathrm{Na}$ fase inicial das perfurações dos poços de monitoramento foi realizado, em cada furo um ensaio de permeabilidade (ensaio de rebaixamento) da zona não-saturada a fim de se estabelecer a velocidade de infiltração da água nestes pontos. A profundidade dos trechos de ensaio variou de $1,20 \mathrm{~m}$ a $4,20 \mathrm{~m}$, com média de 2,5 metros. Apenas em um poço $\left(\mathrm{n}^{9} 10\right)$ não foi realizado o ensaio devido aos sucessivos desmoronamentos ocorridos durante a escavação.

O procedimento dos ensaios obedeceu às diretrizes da ABGE (1990). Os valores da permeabilidade média em cada trecho ensaiado foram obtidos por meio da utilização do Softwer Bombtest (CLARKE, 1987). 


\subsubsection{Coleta de amostras indeformadas para ensaio da porosidade efetiva}

Foram coletadas, em conjunto com a equipe técnica do Laboratório de Física do Solo do Instituto de Pesquisas Tecnológicas - IPT, amostras indeformadas na zona não-saturada, em um ponto no domínio dos sedimentos terciários.

O objetivo desta amostragem foi a realização de ensaios em laboratório para obtenção da porosidade efetiva, isto é o índice de macroporos responsáveis pela percolação da água no solo.

O local da amostragem foi a Pça. Jesuíno Bandeira, junto ao poço de monitoramento $n^{0} 8$ (Figura 8). Tal local foi selecionado com base no conhecimento prévio das litologias por meio da perfuração dos poços, e também na exeqüibilidade da escavação, tendo em conta a sua considerável dimensão para a amostragem.

Foi escavada uma trincheira de $0,80 \times 1,50 \times 1,00 \mathrm{~m}$, de onde as amostras foram coletadas em um cilindro de $300 \mathrm{~cm}^{3}$, a profundidades de 0,50 a $0,57 \mathrm{~m}$.

\subsubsection{Monitoramento em poços e nascentes}

Foram medidas as vazões das nascentes, cronometrando-se o tempo gasto para o preenchimento de um volume conhecido.

As oscilações do nivel dágua foram medidas diretamente, utilizando-se o medidor de nivel d'água elétrico. Tais medições foram efetuadas mensalmente, na estação seca, e quinzenalmente, na estacão úmida.

Os parâmetros físico-químicos das águas nos poços e nascentes, monitorados in situ, foram o pH, condutividade elétrica, alcalinidade total, acrescentando-se também o cloro livre e o fluoreto, estes últimos somente nas nascentes.

Os aparelhos utilizados para medição do $\mathrm{pH}$ e condutividade elétrica foram, respectivamente, o pHâmetro e o condutivimetro, portáteis.

As medições de cloro livre e fluoreto foram efetuadas para esclarecimento quanto à procedência das águas das nascentes ser de origem natural, ou de vazamentos da rede de abastecimento. A cloração é feita com hipociorito $(\mathrm{HOCl})$ e a fluoretação com o ácido flúor silicico $\left(\mathrm{H}_{2} \mathrm{SiF}_{6}\right)$. As concentrações residuais do cloro livre e fluoreto na rede são de 0,6 e 0,7 $\mathrm{mg} / \mathrm{L}$, respectivamente (SABESP - informações verbais).

O fluoreto foi medido utilizando-se o aparelho Aqua-Color, cujo princípio é o de uma reação colorimétrica, com escala máxima de $1,5 \mathrm{mg} / \mathrm{L}$, e precisão de $0,01 \mathrm{mg} / \mathrm{L}$ e leitura ótica.

O cloro livre foi medido com o aparelho Visodisc, cujo método é do DDP (reação do $\mathrm{N}, \mathrm{N}$-dietil-p-fenileno-diamina com o cloro livre, produzindo uma coloração róseo-avermelhada), 
com escala máxima de $3,0 \mathrm{mg} / \mathrm{L}$ e precisão de $0.1 \mathrm{mg} / \mathrm{L}$. A leitura é feita numa escala de comparação colorimétrica.

Devido ao tempo relativamente grande requerido para para a realização das medições do cloro livre e fluoreto, em torno de 25 minutos, para ambas, em cada ponto, as leituras não foram realizadas sistematicamente.

A alcalinidade total foi medida utilizando-se o polititulador da Polilab, cuja precisão de descarga, associada à constituição da escala de leitura, possibilita uma precisão de $0,05 \mathrm{ml}$. Este parâmetro foi medido por ocasião das coletas de amostras de água realizadas para encaminhamento ao laboratório.

\subsubsection{Amostragem da água}

Foram programadas, durante um ano, quatro campanhas de amostragem das águas dos poços de monitoramento e das nascentes, para a realização de análises, visando à caracterização de sua qualidade química. Realizou-se uma amostragem a cada três meses, aproximadamente, no ano de monitoramento.

O procedimento da amostragem adotado seguiu o constante no Guia de Preservação e Coleta de Amostra da CETESB (1988). Nos poços, a água foi retirada manualmente, com caçamba confeccionada em PVC com 1 litro de capacidade. As amostras foram acondicionadas em garrafas de polietileno, e conservadas com ácido nítrico (em $\mathrm{pH}$ menor que 2), e as destinadas à análise de ânions foram refrigeradas a $-4^{\circ} \mathrm{C}$.

\subsection{ATIVIDADES DE LABORATÓRIO}

\subsubsection{Análise química das águas dos poços e das nascentes}

Os parâmetros analisados em laboratório, foram os íons maiores e elementos traços de alguns metais indicadores de poluição. Os cátions maiores analisados foram $0 \mathrm{Ca}^{+2}, \mathrm{Mg}^{+2}$, pelo método da aborção atômica, e $\circ \mathrm{N}^{+1}$ e $\mathrm{K}^{+2}$, pelo método de espectrofotometria de chama. Os íons menores, $\mathrm{Fe}$ (total), $\mathrm{Cu}, \mathrm{Mn}, \mathrm{Al}, \mathrm{Zn}$ e $\mathrm{Pb}$ foram também analisados pelo método de absorção atômica. Os ânions maiores foram o $\mathrm{HCO}_{3}^{-2}, \mathrm{Cl}^{-1}, \mathrm{SO}_{4}^{-2}$ e $\mathrm{NO}^{-3}$, analisados pelo método de cromatografia líquida.

\subsubsection{Ensaio granulométrico do solo}

O método do ensaio adotado é o do peneiramento e pipetagem, sendo que os resultados foram processados no programa LABSE 2, que utiliza a classificação granulométrica de SHEPARD (1954) e parâmetros estatísticos de FOLK e WARD (1957): 
A classificação granulométrica das amostras dos perfis dos poços de monitoramento, em cujos locais foram também coletadas as amostras indeformadas para ensaio da porosidade efetiva, foi feita segundo a United States Departament of Agricultural (USDA). Este ensaio é realizado de acordo com o método do densimetro (GEE, 1986), que consiste em uma fase de tratamento da amostra com dispersantes químico e físico, e outra de quantificação dos diferentes tamanhos das partículas sólidas menores que $2 \mathrm{~mm}$, através do peneiramento e sedimentação em água.

\subsubsection{Ensaio da porosidade efetiva}

A porosidade efetiva foi obtida por meio do ensaio de retenção especifica, realizado no Laboratório de Física do Solo do IPT, em amostras indeformadas, coletadas no local do Poço nº 08 (Figura 6 e Figura 8).

A curva de retenção de água relaciona o conteúdo de água do solo à energia potencial mátrica, que é a força com que a água se encontra retida no espaço poroso, ou seja, na sua matriz.

Para a elaboração da curva de retenção, foram determinadas as umidades dos solos relacionadas com tensões de $0,5,10,20,50,80,300,600$ e $15.000 \mathrm{~cm} \mathrm{H} \mathrm{H}_{2}$. Os pontos de baixa tensão $(0,05$ a $0,1 \mathrm{~atm})$ da curva caracteristica de retenção de água são determinados em laboratório, utilizando-se funis de placa porosa. Os pontos de média e alta tensão $(0,1$ a $15 \mathrm{~atm})$ são determinados nas câmaras de Richards, conforme método descrito por KLUTE (1986).

No estudo da distribuição dos poros é adotada a seguinte classificação: poros maiores que $100 \mu \mathrm{m}$ (macroporos), entre 100 e $30 \mu \mathrm{m}$ (mesaporos) e menores que $30 \mu \mathrm{m}$ (microporos). Estes limites referem-se às tensões de 30 e $100 \mathrm{~cm}$ de $\mathrm{H}_{2} \mathrm{O}$, respectivamente. Tal classificação deve-se ao fato de que os macroporos são os responsáveis pelo escoamento da água no solo, constituindo a porosidade efetiva; os mesoporos, pela distribuição de água no espaço; e os micros, pela retenção da água.

\subsubsection{Estimativa da área impermeável}

A estimativa da área impermeável foi realizada a partir de dados de taxa de ocupação em amostras de lotes tomados aleatoriamente em quatro zonas de ocupação urbana existentes na área $\left(Z_{1}, Z_{2}, Z_{3}\right.$ e $\left.Z_{6}\right)$. As informações referentes aos índices de ocupação dos lotes foram obtidos junto à Unidade de Processamento da Prefeitura Municipal (AR-LA).

Os resultados de cada amostragem por zona foram extrapolados para a área total das respectivas zonas e posteriomente, para toda área de estudos. 


\subsubsection{O Balanço Hídrico Climatológico}

O balanço hídrico climatológico foi realizado objetivando a obtenção dos componentes do balanço hídrico (Evapotranspiração e Excedente hídrico, este incluindo a infiitração e escoamento superficial ou Runoff).

O método do Balanço Hídrico Climatológico foi o de THORNTHWAITE (1955), adaptado por CAMARGO (1960) para as condiçōes climatológicas brasileiras.

\section{CARACTERIZAÇÃO DA ÁREA DE ESTUDO}

\subsection{FISIOGRAFIA}

No dominio sedimentar a conformação topográfica regional é de colinas suaves, tabuliformes, e de espigões bem detalhados, de onde se sobressai o espigão central Sumaré - Paulista, interflúvio natural das Bacias dos Rios Tietê e Pinheiros, com altitudes em torno de $800 \mathrm{~m}$.

A área está geomorfologicamente situada na vertente do espigão central que drena para o Rio Tietê (Figura 6). Compreende a área desde o divisor destas bacias, nos trechos onde estão implantadas partes da avenidas Heitor Penteado e Dr. Arnaldo, até a várzea do Rio Tietê.

As altitudes máxima e mínima encontradas são respectivamente, $832 \mathrm{~m}$, no Bairro Sumaré, e $721 \mathrm{~m}$, na várzea do Rio Tietê, correspondendo, portanto a uma amplitude total de $111 \mathrm{~m}$.

O relevo é nitidamente condicionado às litologias. Nas áreas ocupadas pela várzea do Rio Tietê, limitada até a altura da cota $725 \mathrm{~m}$, predomina um relevo suavizado, com amplitudes da ordem de 1 a $3 \mathrm{~m}$. Ressalta-se que em grande parte os sedimentos da várzea foram aterrados, em virtude da retificação do Rio Tietê, que possuía vários braços e meandros abandonados ao longo do seu percurso.

A partir da cota $725 \mathrm{~m}$, à medida que se avança para SW, no sentido da av. Heitor Penteado, os sedimentos terciários da Bacia de São Paulo sustentam um relevo de colinas, com declividades máximas de $25 \%$ até a altura da cota 750 .

Entre as cotas $750 \mathrm{~m}$ e 800 predomina um relevo já bem mais ingreme, com declividades médias freqüentemente superiores a $25 \%$, principalmente junto às cabeceiras das drenagens, profundamente esculpidas nos sedimentos lateríticos da formação São Paulo, mais resistentes à erosão. 


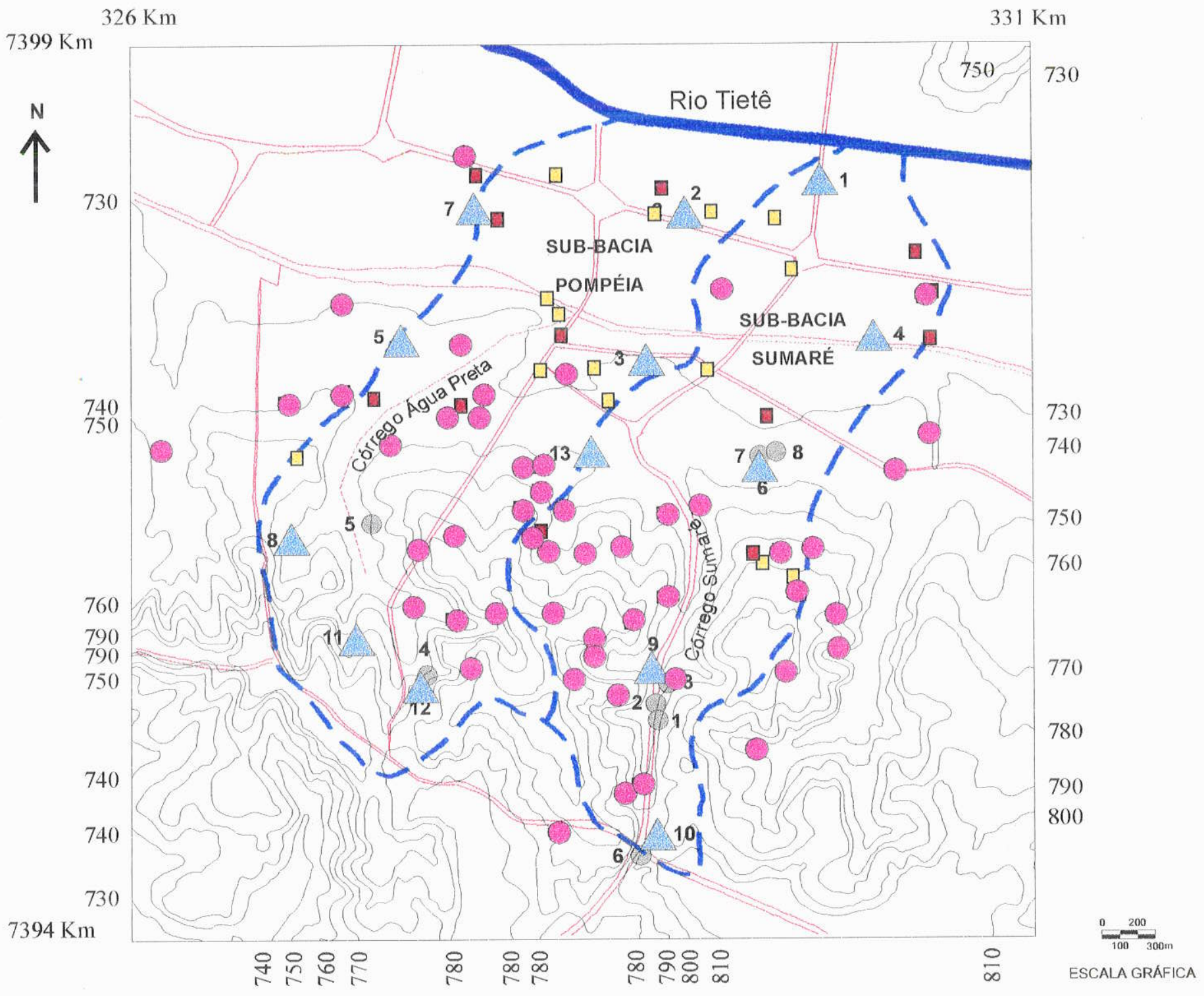

Figura 6 - Fisiografia e pontos d'água

\section{LEGENDA}

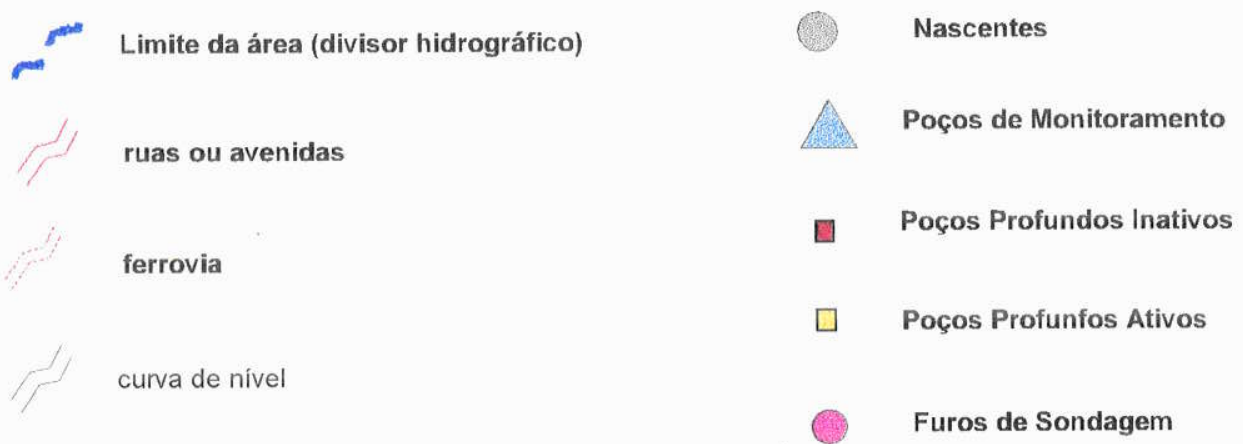




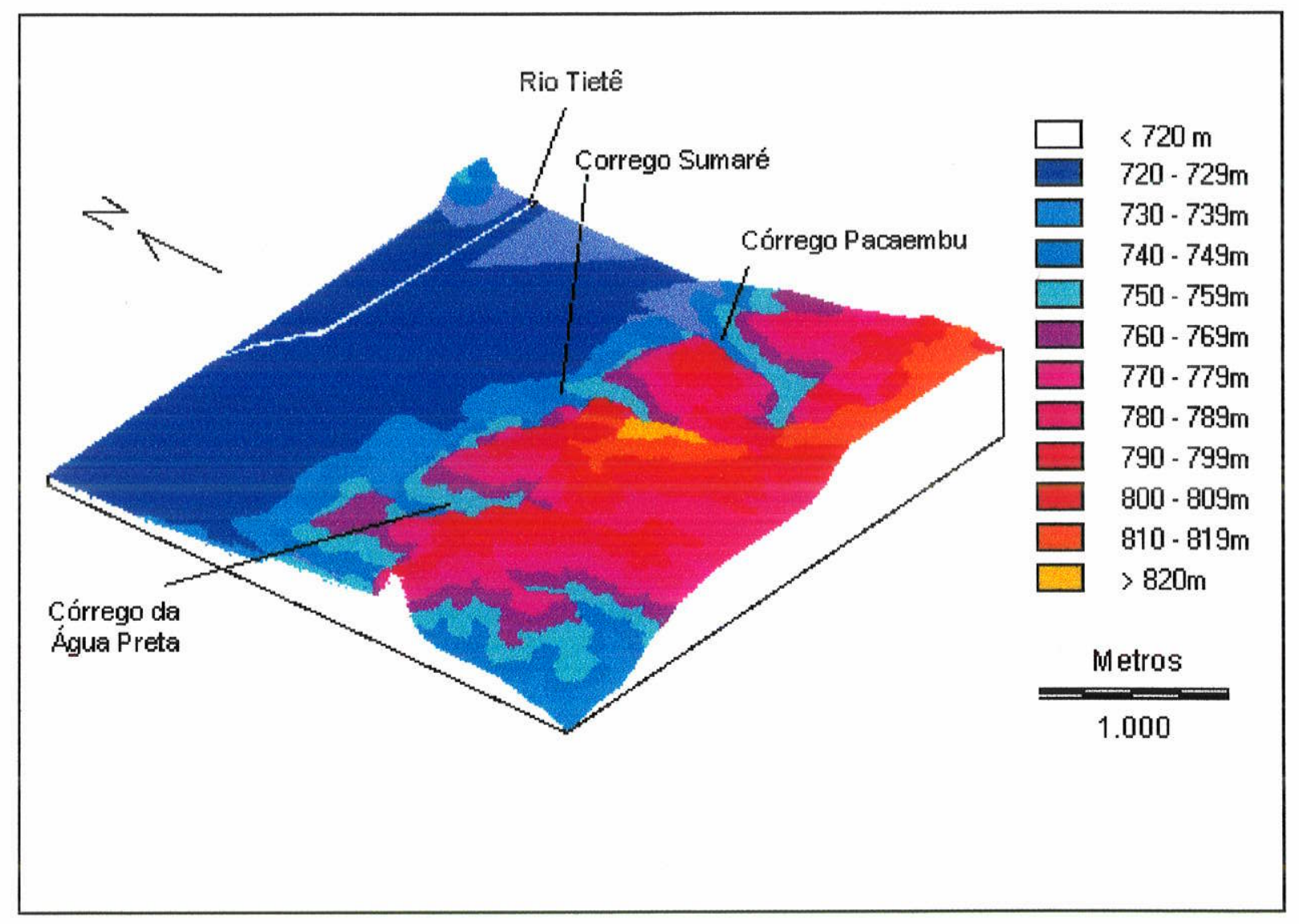

FIGURA 6A - Superfície topográfica. 
Acima da cota $800 \mathrm{~m}$, o relevo se torna mais suavizado, correspondendo ao topo das zonas de interflúvio entre as sub-bacias Sumaré e Pompéia, na porção centro-sul da área, onde atinge as cotas mais elevadas - $806 \mathrm{~m}$ e $832 \mathrm{~m}$.

Os córregos que drenam as sub-bacias Sumaré e Pompéia, córrego Sumaré e córrego da Água Preta, respectivamente, encontram-se, hoje, bastante modificados no seu percurso e dinâmica de escoamento, devido às atividades impostas pela urbanização, que culminou na retificação e no confinamento dos mesmos em galerias de águas pluviais (GAP's). A maior interferência ocorreu no córrego Sumaré, a partir do cruzamento com a Av. Antártica, onde, pelas feições topográficas verifica-se que este córrego era efluente direto do córrego da Água Preta, situado à sua esquerda. Entretanto, verifica-se na atualidade um redirecionamento do curso do mesmo em direção ao Rio Tietê, conforme traçado naquele citado mapa.

Em ambos os córregos, os tributários menores estão concentrados no seu alto curso, com nascentes na altura da cota $775 \mathrm{~m}$, encontrando-se encaixados nos fundos de vales profundos, das encostas do espigão central. Tais córregos encontram-se dispostos em galerias de águas pluviais, somando $1,45 \mathrm{~km}$ e $1,8 \mathrm{~km}$ nas sub-bacias Pompéia e Sumaré, respectivamente (EMURB, 1974).

Verifica-se ainda a presença de águas de efluentes domésticos que comumente são lançados, clandestinamente, ao longo das galerias, observando-se fluxos significativos nestas galerias, mesmo durante a estação seca.

\subsection{CLIMA}

Foram levantados dados médios mensais de temperatura de 13 anos (1980 a 1992), sendo que as médias anuais oscilam entre 19 e $20^{\circ} \mathrm{C}$. Os valores médios mais baixos situamse abaixo de $19^{\circ} \mathrm{C}$, correspondentes aos meses de maio a agosto, sendo julho o mês mais frio. Já os valores médios mensais mais elevados, entre 21 e $23^{\circ} \mathrm{C}$, ocorrem de novembro a março, sendo fevereiro o mês mais quente.

Para a avaliação das variações espaciais das chuvas na área, o mais atual possivel, foi levantada uma uma série histórica de 13 anos (1980 a 1992) de três postos pluviométricos controlados pelo DAEE/CTH, sendo dois situados no entorno da área de estudos, a menos de $4 \mathrm{~km}$ da mesma - Postos Lapa (E3-010) e Ponte Pequena (E3-096) - e um dentro da área de estudos - Posto Água Branca (E3-003) - Figura 1. Verificou-se, entretanto, que o número de falhas de leituras era demasiado nos Postos Água Branca (30\%) e Ponte Pequena (25\%). Apenas o Posto Lapa possuía $0,6 \%$ de falhas, isto é uma falha em 156 meses de leitura. 
Apenas o Posto "Lapa" foi utilizado para avaliação das variações temporais do regime pluviométrico, não sendo possivel, portanto, avaliar com confiabilidade, as variações espaciais.

O regime de chuvas foi caracterizado por dois períodos marcantes de distribuição mensal, sendo um úmido, que se estende de outubro a março, compreendendo cerca de $70 \%$ do total anual precipitado, e outro mais seco, de abril a setembro (Figura 7).

De acordo com os dados pluviométricos levantados naqueles postos, as médias totais anuais são em torno de $1.513 \mathrm{~mm} \pm 243 \mathrm{~mm}$, variando de $1155 \mathrm{~mm}$ (ano de 1985) a $2166 \mathrm{~mm}$ (ano de 1983). As médias mensais no período chuvoso (outubro-março) variam de $108-237$ $\mathrm{mm}$ enquanto no período seco (abril-setembro) de $37-101 \mathrm{~mm}$.

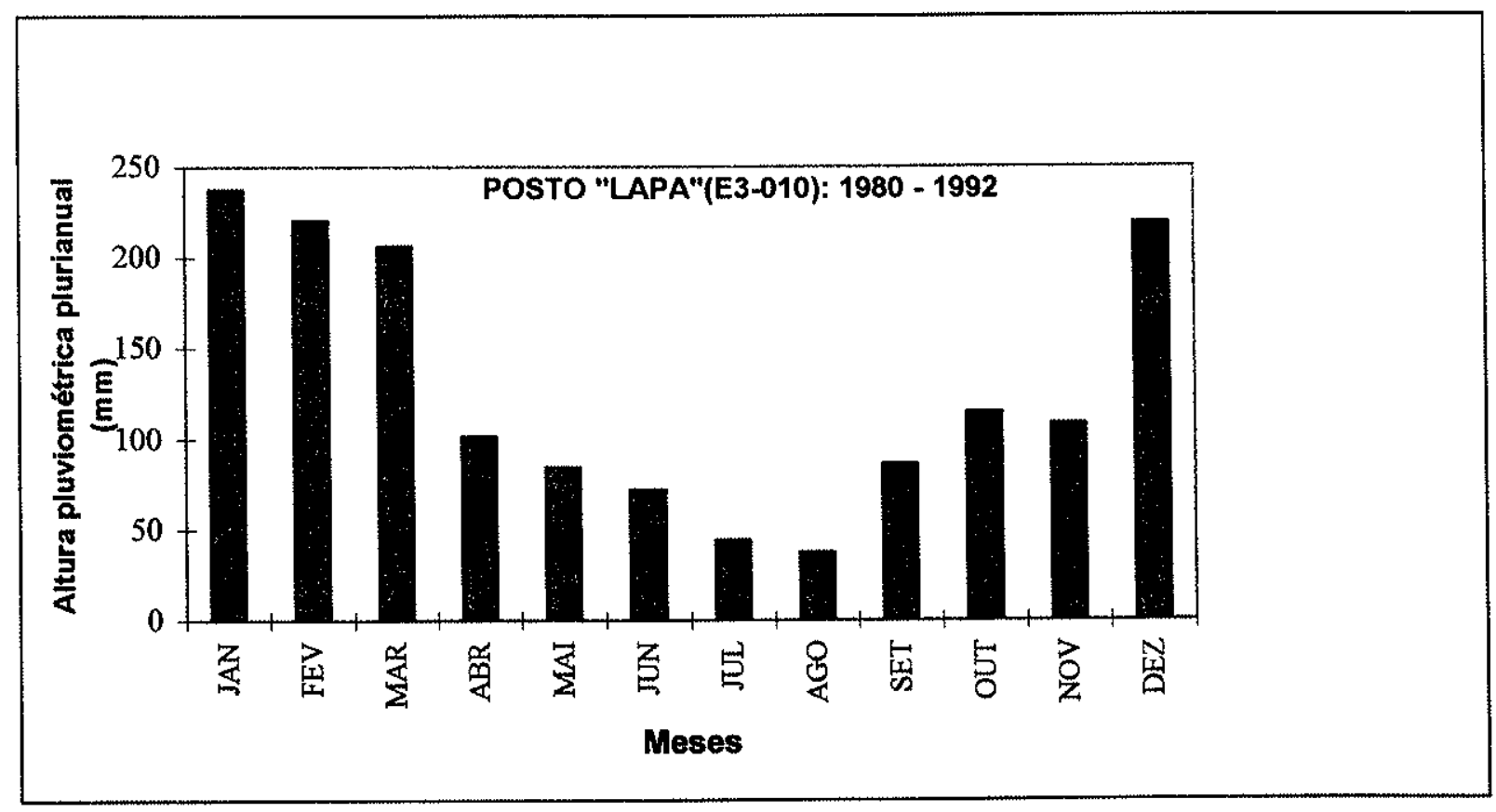

FIGURA 7 - Pluviometria mensal plurianual do Posto Pluviométrico "Lapa"

\subsection{GEOLOGIA}

Atendendo aos objetivos deste estudo foi dada maior ênfase à caracterização dos solos mais superficiais, onde se iniciam os processos de recarga.

A investigação direta do solo, por meio da perfuração de 13 poços para monitoramento dos níveis d'água na área (Figura 8 - adaptada de SABESP/CEPAS, 1994), permitiu o reconhecimento das litofácies mais superficias das formações São Paulo e Resende (até a profundidade de 12 metros). Informações a maiores profundidades, foram obtidas por meio do cadastro de 51 sondagens tipo SPT e de 28 poços profundos 


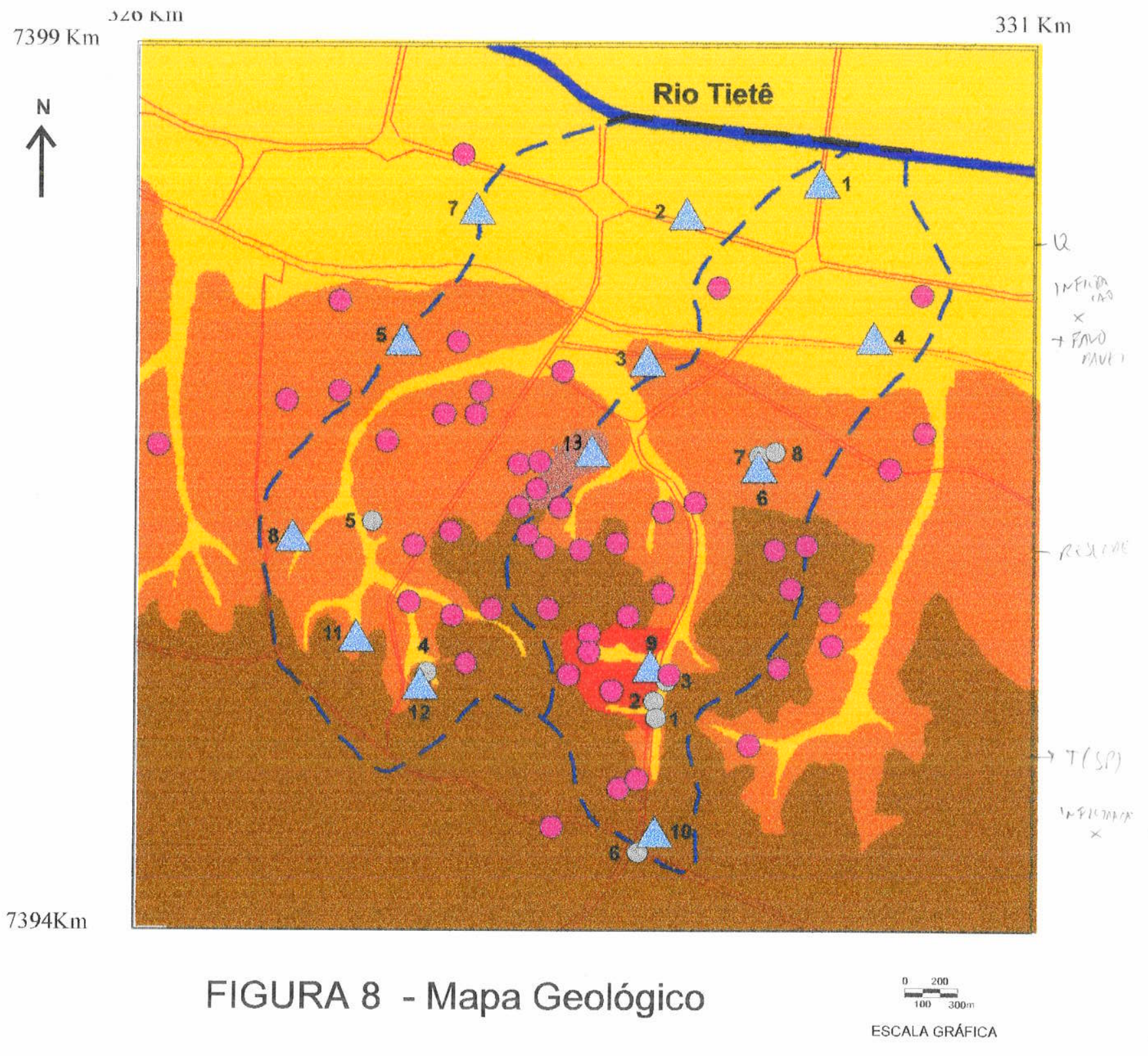

\section{LEGENDA}

\section{CENOZÓICO: QUATERNÁRIO}

Depósitos sedimentares aluviais predominantemente areno-argilsos e subordinadamente com intercalaçöes de cascalho CENOZÓICO : TERCIÁRIO

Formaçäo São Paulo - depósitos de sistema fluvial meandrante compreendendo principalmente camadas decimétricas com granulometria variando da base para o topo, de cascalho, areia, localmente conglomerática a silte-argila

Formação Resende ( fácies distal )- depósitos de sistemas de leques aluviais a planície aluvial entrelaçada. Predominância de lamitos arenosos a argilosos, com seixos e fragmentos de quartzo, quartzito e rochas do embasamento, com intercalações subordinadas de atė $1 \mathrm{~m}$ de espessura de areias e cascalhos com estratificação cruzada PROTEROZÓICO

Rochas granitóides predominantemente orientadas e/ou foliadas, de granulaçäo variada incluindo porçöes gnáissicas migmatiticas e blastomiloniticas subordinadas

Nascentes

Poços de Monitoramento

Furos de Sondagem
Limite da área (divisor hidrográfico)

ruas ou avenidas

ferrovia 
A Formação São Paulo é de ocorrência mais restrita na área, expondo-se, em geral. acima da cota $775 \mathrm{~m}$, e sustentando as feições mais elevadas do relevo na porção sul. É nítida, nesta formação, o desenvolvimento de um perfil de solo tipicamente laterítico (presença de materiais de óxidos de ferro e alumínio), formado de uma camada superior de até 8 metros de espessura, tendo sido interceptada pelos Poços de monitoramento $n^{\text {os }} 10,11,12$ e 13 . Esta camada é constituida de um material predominantemente argiloso com $55-70 \%$ de argila, tipicamente vermetha, não estruturada, e contém frações menores de areia, com presença eventual de seixos quartzosos milimétricos esparsos. Em Geologia de Engenharia da Bacia de São Paulo é denominada de argila porosa, devido ao grande número de vazios.

A Fm. Resende ocorre sob os sedimentos da Fm. São Paulo, ocupando a parte mais central da área de estudos. Foram perfurados, neste dominio, quatro poços de monitoramento $\left(n^{\text {os }} 3,5,6,8\right)$, com profundidades entre 3,8 e 9,2 m. A fácies litológica desta formação que ocorre na área é a distal (RICCOMINI, 1989).

Ao longo dos perfis observa-se a presença de camadas intercaladas, centimétricas a métricas de argilas arenosas, argilas sílticas, argilas, areias argilosas e areias. Nas camadas de argilas arenosas a proporção de argila+silte é de $55-75 \%$, nas camadas de argilas sílticas é de $89 \%$, e nas camadas de argilas é de $95-98 \%$. Nas camadas de areias argilosas a fração de areia+grânulos encontrada foi de $43-77 \%$ e nas essencialmente arenosas, uma fração de areia de $83 \%$.

A heterogeneidade granulométrica dos solos pode ser melhor visualizada nas Figuras 1 a 9 do Anexo 2, que representam as curvas de distribuição granulométrica de amostras coletadas no terreno terciário.

Os resultados das análises granulométricas em amostras coletadas a diferentes profundidades durante a perfuração de oito poços de monitoramento nos sedimentos terciários estão expostos na Tabela 1. A descrição táctil e visual das litologias encontram-se nos perfis dos poços do Anexo 1.

De uma forma geral, a seqüência encontrada nas duas formações, por meio dos furos executados, a partir de aproximadamente 1,0 metro abaixo do nível d'água, foi de camadas de areia média a grossa na base (com presença de uma pequena fração de pedregulhos e seixos) gradando para camadas de variadas frações de areia, argila e silte intercaladas entre si, proporcionando características de seleção granulométrica muito pobres.

Embora o Poço 9 tenha sido perfurado no domínio da Fm São Paulo, os estratos aí encontrados parecem ser correlacionáveis à $\mathrm{Fm}$. Resende. A presença de um corpo de rocha granitóide junto à Av. Sumaré, o qual representa uma janela do embasamento cristalino, deve ter fornecido o material de sedimentação do depósito aí existente. Foram encontrados 
grânulos grosseiros de quartzo, micas e de minerais facetados de quarzto e feidspato de até $5,0 \mathrm{~cm}$ de diâmetro, dentro de matriz de areia argilosa cinza, a 4,8 metros de profundidade.

No dominio dos aluviōes quaternários que ocupam a várzea do Rio Tietê, quatro poços foram perfurados ( $n^{\text {os }} 1,2,4$ e 7 ), cujas cotas situam-se entre 721 e $722 \mathrm{~m}$. As espessuras das camadas de aterro variam de 0,8 a $3,2 \mathrm{~m}$, possuindo composição bastante diversificada, de local para local. Abaixo do aterro ocorre uma camada de argila orgânica, plástica, cinza a esverdeada.

Sotopostos aos sedimentos terciários e quaternários encontram-se as rochas do embasamento cristalino a variadas profundidades, de 55 a 124 metros, segundo dados do cadastro dos poços profundos, destacando-se uma única ocorrência em superfície, observada na av. Sumaré, acima citada.

Por tratar-se de uma área já bastante urbanizada, as camadas mais superficiais dos solos sofreram intensa intervenção por escavações e aterros, estes com mistura de materiais de diversas granulometrias, descaracterizando o solo original e acentuando ainda mais a heterogeneidade textural dos solos. Os aterros observados possuem variada espessura, oscilando de 0,6 a $2,4 \mathrm{~m}$, com média de $1,20 \mathrm{~m}$. 


\begin{tabular}{|c|c|c|c|c|c|c|c|c|}
\hline $\begin{array}{c}N^{\mathbf{0}} \\
\mathrm{POCO}\end{array}$ & $\begin{array}{c}\mathrm{N}^{0} \mathrm{da} \\
\text { Amostra }\end{array}$ & $\begin{array}{c}\text { Intervalo } \\
\text { Amostrado } \\
\text { (m) }\end{array}$ & $\begin{array}{c}\% / \% \\
\text { Grânulos }\end{array}$ & $\begin{array}{c}\% \\
\text { Areia }\end{array}$ & $\begin{array}{c}\% \\
\text { Siltetargila }\end{array}$ & $\begin{array}{c}\% \\
\text { Argila }\end{array}$ & $\begin{array}{c}* \star \\
\mathrm{Gr} / \mathrm{Fi}\end{array}$ & $\begin{array}{l}\text { Classificação } \\
\text { granulométrica } \\
\text { (Shepard, 1954). }\end{array}$ \\
\hline 03 & $\begin{array}{l}032 \\
034 \\
035 \\
038 \\
039 \\
\end{array}$ & $\begin{array}{c}0.90-2.2 \\
3.8-4.6 \\
4.6-5.4 \\
7.2-7.45 \\
7.6-8.0 \\
\end{array}$ & $\begin{array}{l}0.13 \\
4.35 \\
0.58 \\
0.76 \\
3.23 \\
\end{array}$ & $\begin{array}{l}42.53 \\
37.05 \\
40.33 \\
44.55 \\
71.96\end{array}$ & $\begin{array}{c}57,33 \\
58.6 \\
59.08 \\
54,69 \\
24.80 \\
\end{array}$ & $\begin{array}{l}42.29 \\
51.86 \\
48.89 \\
41.17 \\
18.11 \\
\end{array}$ & $\begin{array}{l}0.74 \\
0.71 \\
0.69 \\
0.83 \\
3.03 \\
\end{array}$ & $\begin{array}{c}\text { areia argilosa } \\
\text { argila arenosa } \\
\text { argila arenosa } \\
\text { areia argilosa } \\
\text { areia argilosa } \\
\end{array}$ \\
\hline 05 & $\begin{array}{l}051 \\
052 \\
053 \\
054 \\
055 \\
056 \\
057 \\
\end{array}$ & $\begin{array}{c}0.20-1.36 \\
1.36-2.40 \\
2.40-3.00 \\
4.20-5.20 \\
5.20-6.20 \\
6.20-7.00 \\
7.00-8.30 \\
\end{array}$ & $\begin{array}{l}0.08 \\
0.33 \\
0.39 \\
0.25 \\
0.08 \\
0.00 \\
0.89\end{array}$ & $\begin{array}{c}35.16 \\
32.24 \\
33.8 \\
29.67 \\
10.62 \\
1.64 \\
81.96 \\
\end{array}$ & $\begin{array}{l}64.76 \\
67.43 \\
65,81 \\
70,08 \\
89,30 \\
98,36 \\
17.15 \\
\end{array}$ & $\begin{array}{l}56.94 \\
59.42 \\
50,21 \\
46.39 \\
74,86 \\
76.08 \\
13.79 \\
\end{array}$ & $\begin{array}{l}0.54 \\
0.48 \\
0.52 \\
0.43 \\
0.14 \\
0.02 \\
4.83 \\
\end{array}$ & $\begin{array}{c}\text { argila arenosa } \\
\text { argila arenosa } \\
\text { argila arenosa } \\
\text { argila arenosa } \\
\text { argila síltica } \\
\text { argila } \\
\text { areia } \\
\end{array}$ \\
\hline 06 & $\begin{array}{l}061 \\
063 \\
065 \\
066 \\
\end{array}$ & $\begin{array}{l}0,0-0.5 \\
0,65-1,5 \\
1,9-3,4 \\
3.4-3.7 \\
\end{array}$ & $\begin{array}{c}16,85 \\
3,03 \\
1,98 \\
13.96 \\
\end{array}$ & $\begin{array}{l}63,26 \\
51,45 \\
41,79 \\
69,37 \\
\end{array}$ & $\begin{array}{l}19,89 \\
45,52 \\
56,23 \\
16.67 \\
\end{array}$ & $\begin{array}{l}15,72 \\
27,33 \\
45.06 \\
11.23 \\
\end{array}$ & $\begin{array}{c}4,03 \\
1,19 \\
0,79 \\
5 \\
\end{array}$ & $\begin{array}{c}\text { areia } \\
\text { areia argilosa } \\
\text { argila arenosa } \\
\text { areia } \\
\end{array}$ \\
\hline${ }^{*} 08$ & $\begin{array}{l}081 \\
082 \\
083 \\
084 \\
085 \\
08 \mathrm{E} \\
08 \mathrm{E} \\
\end{array}$ & $\begin{array}{c}0,7-1,6 \\
1,6-2,0 \\
3,0 \quad 3,6 \\
3,6-4.0 \\
4,0-4,4 \\
0,5-0,57 \\
0.5-0.57 \\
\end{array}$ & $\begin{array}{c}- \\
- \\
- \\
- \\
- \\
- \\
7.92 \\
\end{array}$ & $\begin{array}{c}49 \\
52 \\
58 \\
62 \\
76 \\
54 \\
42.72 \\
\end{array}$ & $\begin{array}{c}51 \\
48 \\
42 \\
38 \\
24 \\
46 \\
49,36 \\
\end{array}$ & $\begin{array}{c}43 \\
40 \\
39 \\
33 \\
19 \\
42 \\
40.30 \\
\end{array}$ & $\begin{array}{l}0,96 \\
1,08 \\
1,38 \\
1.63 \\
3,17 \\
1,17 \\
1,02 \\
\end{array}$ & $\begin{array}{c}\text { argiloso } \\
\text { argiloso } \\
\text { argiloso } \\
\text { médio argiloso } \\
\text { médio arenoso } \\
\text { argiloso } \\
\text { areia argilosa } \\
\end{array}$ \\
\hline 09 & $\begin{array}{l}092 \\
095 \\
096 \\
097 \\
098 \\
\end{array}$ & $\begin{array}{c}0,4-0,8 \\
2,5-2,8 \\
3,6-4,3 \\
4,3-4,6 \\
4,6-5,10 \\
\end{array}$ & $\begin{array}{c}1,86 \\
2,83 \\
1,12 \\
0,64 \\
16,87 \\
\end{array}$ & $\begin{array}{l}24,04 \\
37,50 \\
35,19 \\
29,98 \\
51,21 \\
\end{array}$ & $\begin{array}{l}74,10 \\
59,67 \\
63,69 \\
69,38 \\
31,92 \\
\end{array}$ & $\begin{array}{l}28,31 \\
49,88 \\
50,60 \\
56,48 \\
24,33 \\
\end{array}$ & $\begin{array}{l}0,35 \\
0,67 \\
0,57 \\
0,44 \\
2,8 \\
\end{array}$ & $\begin{array}{c}\text { silte argiloso } \\
\text { argila arenosa } \\
\text { argila arenosa } \\
\text { areia argilosa } \\
\text { areia argilosa } \\
\end{array}$ \\
\hline 10 & $\begin{array}{l}101 \\
103 \\
105 \\
106 \\
107 \\
\end{array}$ & $\begin{array}{l}0,0-0,8 \\
1,7-3,6 \\
6,8-7,2 \\
7,2-7,6 \\
7,6-12,0 \\
\end{array}$ & $\begin{array}{l}1,15 \\
0,10 \\
0,97 \\
4,91 \\
0,06 \\
\end{array}$ & $\begin{array}{l}32,19 \\
21,59 \\
51,02 \\
60,32 \\
5,33 \\
\end{array}$ & $\begin{array}{l}66,65 \\
78,31 \\
39,81 \\
34,77 \\
94,61 \\
\end{array}$ & $\begin{array}{l}35,43 \\
63,94 \\
33,27 \\
27,16 \\
80,46 \\
\end{array}$ & $\begin{array}{l}0,50 \\
0,28 \\
1,30 \\
1,88 \\
0,06 \\
\end{array}$ & $\begin{array}{l}\text { argila síltico- } \\
\text { arenosa } \\
\text { argila arenosa } \\
\text { areia argilosa } \\
\text { areia argilosa } \\
\text { argila } \\
\end{array}$ \\
\hline 12 & $\begin{array}{l}1201 \\
1202 \\
1203 \\
1204 \\
1205 \\
1206 \\
\end{array}$ & $\begin{array}{l}0,0-1,1 \\
1,1-1,4 \\
1,4-2,8 \\
2,8-3,0 \\
3,0-3,4 \\
3,4-3,9 \\
\end{array}$ & $\begin{array}{c}2,20 \\
2,30 \\
1,36 \\
\\
17,04 \\
1,93 \\
\end{array}$ & $\begin{array}{l}52,17 \\
48,44 \\
68,15 \\
\\
60,17 \\
71,33 \\
\end{array}$ & $\begin{array}{l}45,64 \\
49,26 \\
30,49 \\
\\
22,79 \\
26,74 \\
\end{array}$ & $\begin{array}{l}24,86 \\
38,96 \\
13,09 \\
\\
18,14 \\
23.05 \\
\end{array}$ & $\begin{array}{l}1,19 \\
1,03 \\
2,27 \\
\\
3,39 \\
2.74 \\
\end{array}$ & $\begin{array}{l}\text { areia argilosa } \\
\text { areia argilosa } \\
\text { areia argilosa } \\
\text { areia argilosa } \\
\text { areia argilosa } \\
\text { areia argilosa } \\
\end{array}$ \\
\hline${ }^{*} 13$ & $\begin{array}{l}1301 \\
1302 \\
1303 \\
1305 \\
1306 \\
1307 \\
1308 \\
1309 \\
1310 \\
1311 \\
1312 \\
13 E \\
13 E\end{array}$ & $\begin{array}{c}0,0-0,6 \\
0.6-2,5 \\
2,5-4,8 \\
5,0-5,9 \\
5,9-6,7 \\
6,7-7,5 \\
7,5-8,0 \\
8,0-8,8 \\
8,8-9,6 \\
9,6-9,8 \\
9,8-10 \\
0,7-0,77 \\
0,7-0.77\end{array}$ & $\begin{array}{l}- \\
- \\
- \\
= \\
= \\
- \\
= \\
= \\
- \\
- \\
0,13\end{array}$ & $\begin{array}{c}30 \\
28 \\
16 \\
28 \\
22 \\
12 \\
40 \\
68 \\
28 \\
34 \\
29 \\
54 \\
24.79\end{array}$ & $\begin{array}{c}70 \\
72 \\
84 \\
72 \\
78 \\
88 \\
60 \\
32 \\
72 \\
66 \\
71 \\
75 \\
75,08\end{array}$ & $\begin{array}{l}64 \\
68 \\
79 \\
70 \\
68 \\
81 \\
54 \\
29 \\
69 \\
58 \\
66 \\
42 \\
67,05\end{array}$ & $\begin{array}{l}0,43 \\
0,39 \\
0,19 \\
0,38 \\
0,28 \\
0,14 \\
0,67 \\
2,12 \\
0,39 \\
0,51 \\
0,41 \\
0,72 \\
0,33 \\
\end{array}$ & $\begin{array}{c}\text { muito argiloso } \\
\text { muito argiloso } \\
\text { muito argiloso } \\
\text { muito argiloso } \\
\text { muito argiloso } \\
\text { muito argiloso } \\
\text { argiloso } \\
\text { médio argiloso } \\
\text { muito argiloso } \\
\text { argiloso } \\
\text { muito argiloso } \\
\text { muito argiloso } \\
\text { argila arenosa }\end{array}$ \\
\hline
\end{tabular}

* Classificação segundo USDA (United States Department of Agricultural): baseado no teor de argila.

** relação fração grossa - fração fina

TABELA 1 - Granulometria dos materiais constituintes do terreno terciário 


\subsection{HIDROGEOLOGIA}

\subsubsection{Caracterização geral dos aqüíferos}

O nivel d'água investigado está sob condições freáticas, referindo-se ao nivel encontrado durante a execução dos poços de monitoramento, e pelas sondagens SPT cadastradas.

As Formações São Paulo e Resende foram aqui consideradas como um sistema aqüífero único devido às interdigitações entre as suas litofácies e conseqüente conexão hidráulica entre elas.

$\mathrm{Na}$ Figura 9 está representada a superfície potenciométrica, na qual verifica-se nitidamente o estreito controle da fisiografia da área sobre o nivel potenciométrico, com fluxo principal em direção à várzea do rio Tietê, e fluxos secundários em direção aos vales menores. O gradiente hidráulico no aqüífero sedimentar $(0,05)$ é cerca de 10 vezes o observado no aqüifero quaternário $(0,0065)$, explicado pela presença de camadas argilosas, que dificultam a infiltração para as zonas mais profundas do aqüífero, e pela fisiografia acidentada do terreno terciário.

Constatou-se que $42 \%$ dos 55 dados de nivel d'água fornecidos pelas sondagens $S P T$, em toda a área (Figura 8), estão a menos de 4 metros de profundidade e os demais $58 \%$ a mais de 5 metros (Figura 10 ). No terreno terciário tais profundidades ocorrem em áreas elevadas e nos fundos de vales, estando relacionados à presença dos aqüiferos suspensos. Já no dominio quaternário, a profundidade do nível d'água é de ocorréncia constante, devido ao baixo gradiente hidráulico e declive do terreno.

Foram identificados três sistemas aqüiferos principais: o sedimentar fluvio-lacustre (terciário), o cristalino e o sedimentar aluvionar (quaternário), sendo que apenas os dois primeiros são efetivamente explorados para fins de abastecimento na área. O sistema aluvionar ocupa cerca de $30 \%$ da área total, enquanto o terciário o restante.

O principal aqüifero, em termos de potencialidade hídrica, é o sedimentar terciário, constituído das Formações São Paulo e Resende, esta sotoposta à primeira. A espessura média deste pacote sedimentar é de $82 \mathrm{~m}$, de acordo com 10 poços profundos existentes neste domínio. Sua ocorrência em superfície é a partir da cota $725 \mathrm{~m}$.

Destaca-se pela grande heterogeneidade litológica, e pela existência de várias surgências naturais (Figura 6 e Figura 8), verificadas nas encostas das cabeceiras de drenagem, e também ante a intercepção do lençol freático por cortes dos maciços. 

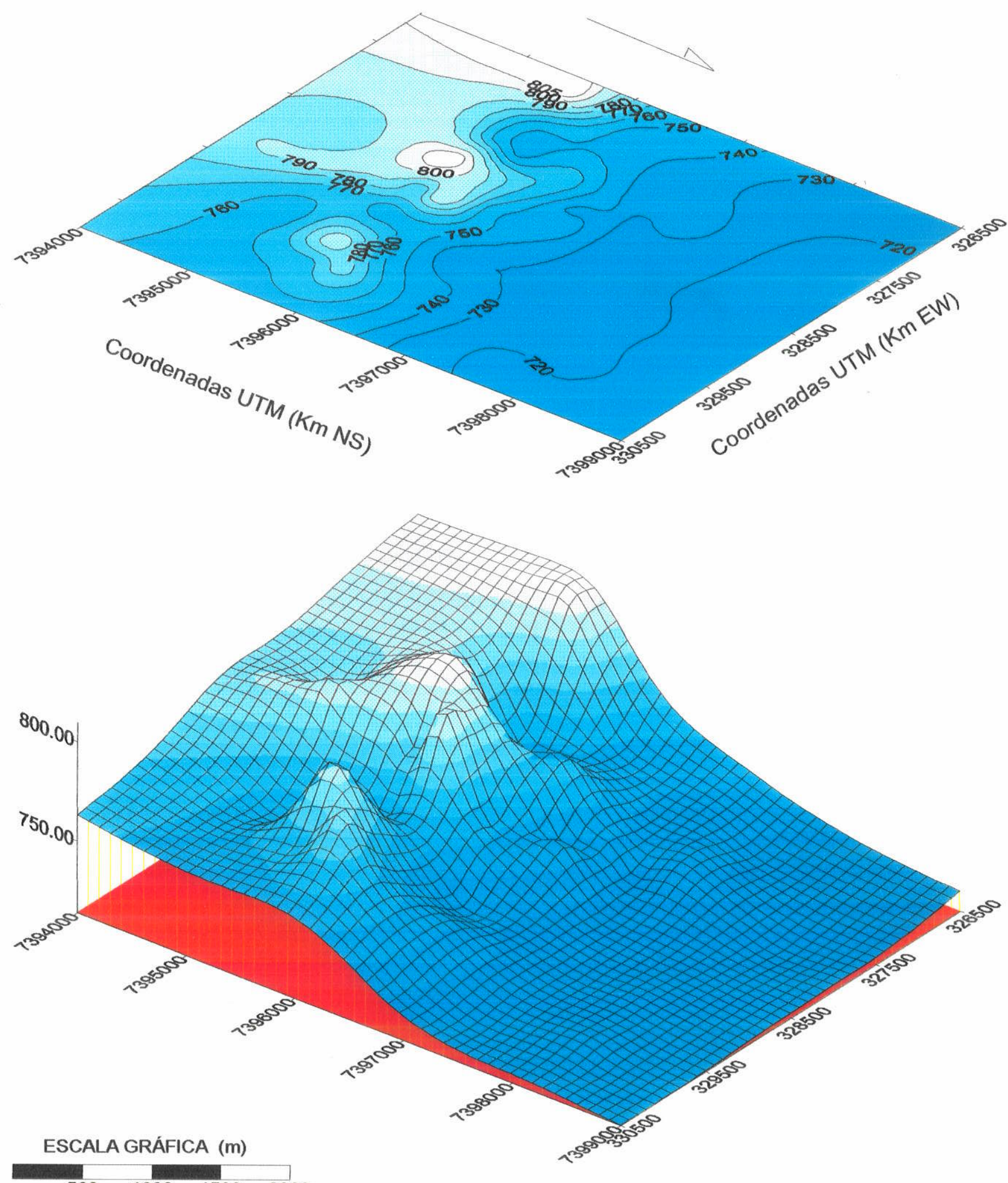

FIGURA 9 - Superfície Potenciométrica 


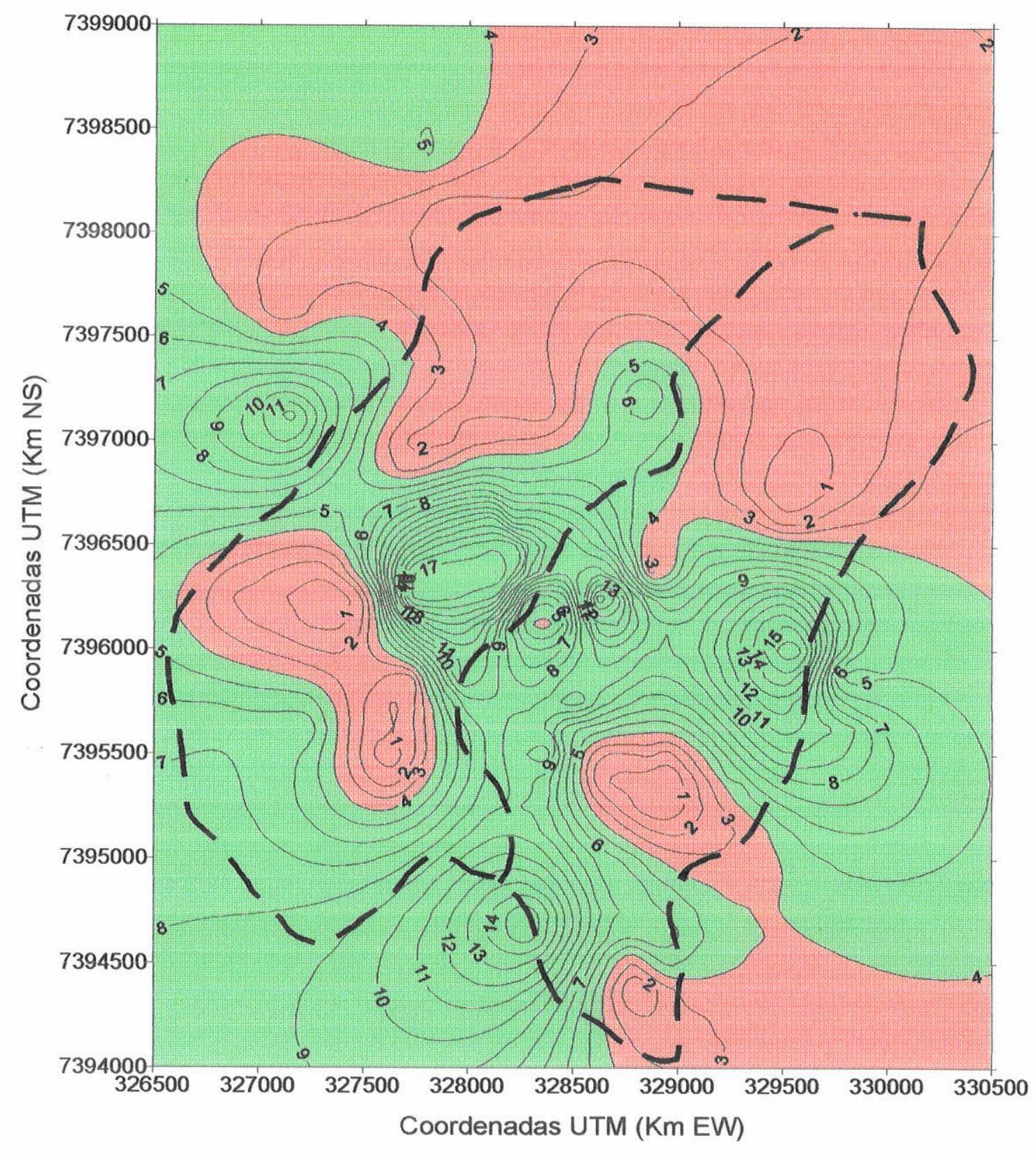

LEGENDA

Área com profundidades do nível d'água de até 4 metros Área com profundidades do nível d'água acima de 4 metros

ESCALA GRÁFICA (m)

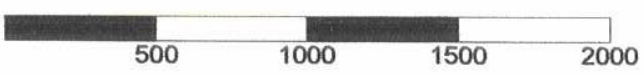

FIGURA 10 - Isoprofundidade do nível d'água 
O condicionamento litológico destas surgências, na Fm. São Paulo, é a existência de interfaces arenosas e argitosas, muitas vezes marcadas pela presença de crostas limoniticas no topo das camadas argilosas, potencializando ainda mais o fluxo ao longo destas interfaces, propiciando a formação de aqüíferos suspensos, a exemplo dos interceptados pelos poços de monitoramento 10 e 12 .

Acima do pacote de intercalações arenosas e argilosas, ocorre uma camada de solo laterizado (materiais cimentantes de aluminio e ferro) de ganulação argilo-arenosa - argila porosa, normaimente encontrado nos topos e meias encostas. Do ponto de vista hidrogeológico estes solos são caracteristicamente bem drenados, insaturados e conferem ao meio uma elevada permeabilidade quando umedecidos. No aspecto da recarga, a exposição destes solos é de extrema importância, pois o mesmo possui boa capacidade para promover rapidamente a infiltração

O outro sistema aqüífero sedimentar corresponde aos depósitos aluvionares holocênicos da várzea do Rio Tietê, sendo, na maioria das vezes difícil a individualização entre os dois sistemas sedimentares. Sob o ponto de vista de produção aqüifera, é de importância secundária, encontrando-se geralmente isolados por revestimentos nos poços profundos. Entretanto assume relativa importância neste estudo, dada a significativa exposição aos processos de infiltração.

\subsubsection{Potencialidades hídricas}

A potencialidade hidrica dos sistemas aqüiferos foi avaliada a partir da produtividade dos poços cadastrados na área.

Embora 28 poços profundos tenham sido cadastrados (Tabela 2), apenas dados de 25 poços foram utilizados na análise da produtividade, por possuirem informações seguras quanto à caracterização das captações em relação aos sistemas aqüíferos.

A destinação das águas subterrâneas exploradas por meio dos poços existentes na área é o abastecimento de indústrias ( $29 \%$ dos poços), estabelecimentos comerciais ( $39 \%)$, clubes $(18 \%)$ e condomínios, escolas e hospitais (14\%). Do total cadastrado, $61 \%$ (17 poços) encontravam-se em operação na época do levantamento.

Do ponto de vista de produção o aqüífero sedimentar terciário é o mais promissor, devido à sua considerável espessura e às intercalações dos estratos arenosos e areno argilosos no pacote sedimentar. Entretanto, apenas $21 \%$ (5 poços) captam água somente do aqüifero terciário; $54 \%$ (13 poços) somente do aqüifero cristalino e $25 \%$ (6 poços) dos dois sistemas - poços de captação mista. 


\begin{tabular}{|c|c|c|c|c|c|c|c|c|c|c|c|c|c|c|c|}
\hline $\begin{array}{l}\text { No. } \\
\text { POço }\end{array}$ & PROPRIETÁRIO & ENDEREÇO & COORL & $\begin{array}{l}\text { ENADAS } \\
\text { M) }\end{array}$ & $\begin{array}{l}\text { ANO } \\
\text { PERF. }\end{array}$ & $\begin{array}{l}\text { COTA } \\
\text { (boca) } \\
\text { (m) }\end{array}$ & $\begin{array}{l}\text { PROF. } \\
\text { (m) }\end{array}$ & $\begin{array}{l}\mathrm{NE} \\
(\mathrm{m})\end{array}$ & $\begin{array}{l}\text { ND } \\
\text { (m) }\end{array}$ & $\begin{array}{c}Q \\
\left(m^{3} / h\right)\end{array}$ & $\begin{array}{c}Q / s \\
\left(m^{3} / h / m\right)\end{array}$ & $\begin{array}{l}\text { PROF. } \\
\text { EMBAS. } \\
\text { (m) }\end{array}$ & $\begin{array}{c}\text { PROF. ENTR. } \\
\text { DÁGUA } \\
\text { (m) }\end{array}$ & $\begin{array}{l}\text { AQUí- } \\
\text { FERO }\end{array}$ & $\begin{array}{l}\text { SUB- } \\
\text { BACIA }\end{array}$ \\
\hline 01 & $\begin{array}{l}\text { Discos RGE } \\
\text { Fermata Ltda }\end{array}$ & $\begin{array}{l}\text { Josef Krys, } 179 \\
\text { B.Funda }\end{array}$ & $\begin{array}{c}X \\
329870\end{array}$ & $\begin{array}{c}\mathbf{Y} \\
7398180\end{array}$ & 1978 & 723 & 180 & 128 & 130,7 & 9,2 & 3,4 & 70 & 176 & Frat. & Pompéia \\
\hline 02 & Center 2.000 & Fco. Matarazzo, 2000 & 328325 & 7397390 & 1977 & 725 & 100 & 11 & 80 & 2 & 0,02 & 100 & $\begin{array}{l}13-15 ; 62-65 \\
72-75 ; 82-85\end{array}$ & Sed. & Pompéia \\
\hline 03 & $\begin{array}{l}\text { Acad. Futebol } \\
\text { Palmeiras }\end{array}$ & M. S.Vicente, 2.650 & 328300 & 7398255 & 1993 & 725 & 270 & 129 & 178 & 6,35 & 0,122 & 81,4 & - & Frat. & Pompéia \\
\hline 04 & Saturnia S.A. & Min. Ferreira Alves, 902 & 327790 & 7396980 & 1964 & 730 & 181 & 21 & 43 & 15,8 & 0,72 & 86 & $\begin{array}{l}34 ; 60 ; 79 \\
130 ; 180\end{array}$ & Misto & Pompéia \\
\hline $\begin{array}{l}05 \\
06\end{array}$ & $\begin{array}{l}\text { Rendas Advance } \\
\text { Saraiva S.A. }\end{array}$ & $\begin{array}{l}\text { Fábia, } 123 \text { - Lapa } \\
\text { M. S. Vicente, } 1697\end{array}$ & $\begin{array}{l}327320 \\
328850\end{array}$ & $\begin{array}{l}7397060 \\
7398030\end{array}$ & 1975 & $\begin{array}{l}745 \\
722\end{array}$ & $\begin{array}{l}045 \\
184\end{array}$ & $\begin{array}{c}19 \\
107\end{array}$ & $\begin{array}{c}36 \\
142,5\end{array}$ & $\begin{array}{l}6,5 \\
6,5\end{array}$ & $\begin{array}{l}0,38 \\
0,18\end{array}$ & $\begin{array}{l}88 \\
68\end{array}$ & $149 ; 165$ & $\begin{array}{l}\text { Sed. } \\
\text { Frat. }\end{array}$ & $\begin{array}{l}\text { Pompéia } \\
\text { Pompéia }\end{array}$ \\
\hline 07 & $\begin{array}{l}\text { Nacional. A. } \\
\text { Clube }\end{array}$ & M. S. Vicente, 2477 & 327980 & 7398020 & $\begin{array}{l}1974 \\
1976\end{array}$ & 720 & 250 & $\begin{array}{c}106 \\
97\end{array}$ & $\begin{array}{l}110 \\
114\end{array}$ & $\begin{array}{l}5,5 \\
7,2\end{array}$ & $\begin{array}{l}1,38 \\
0,42\end{array}$ & 72 & - & Misto & Pompéia \\
\hline $\begin{array}{l}08 \\
09 \\
10 \\
11\end{array}$ & $\begin{array}{l}\text { DPA Soc. Agricola } \\
\text { Opium Motel } \\
\text { Jovem Pan } \\
\text { Futura S.A. }\end{array}$ & $\begin{array}{l}\text { Pque. Água Branca } \\
\text { Pça. P. Martins, } 54 \\
\text { Várzea, 240 } \\
\text { Tomás Edson, } 903\end{array}$ & $\begin{array}{l}329420 \\
329125 \\
330330 \\
329490\end{array}$ & $\begin{array}{l}7396950 \\
7398070 \\
7397350 \\
7398030\end{array}$ & $\begin{array}{l}1951 \\
1994 \\
1973 \\
1970 \\
1993\end{array}$ & $\begin{array}{l}725 \\
722 \\
723 \\
721\end{array}$ & $\begin{array}{l}059 \\
200 \\
250 \\
284\end{array}$ & $\begin{array}{c}10 \\
143,7 \\
132 \\
100\end{array}$ & $\begin{array}{c}31,5 \\
159,8 \\
159,8 \\
110 \\
200\end{array}$ & $\begin{array}{c}2 \\
15,53 \\
4,6 \\
14 \\
12\end{array}$ & $\begin{array}{c}0,09 \\
0,94 \\
0,16 \\
1,4\end{array}$ & $\begin{array}{l}- \\
76 \\
78 \\
29\end{array}$ & $\begin{array}{l}- \\
-\end{array}$ & $\begin{array}{l}\text { Frat. } \\
\text { Frat. } \\
\text { Frat. }\end{array}$ & $\begin{array}{l}\text { Sumaré } \\
\text { Pompéia } \\
\text { Sumaré } \\
\text { Sumaré }\end{array}$ \\
\hline 12 & Cia. Tel Bras. & M. S. Vicente, 206 & 330250 & 7397830 & 1972 & 722 & 200 & 130 & 145 & 2,6 & 0,17 & 70 & - & Frat. & Sumaré \\
\hline 13 & Condom. B. & Dr. Homem de Melo, 697 & 329360 & 7396190 & 1972 & 766 & 109 & 24 & 80 & 0,6 & 0,01 & 55 & $45-53 ; 75-85$ & Misto & Sumaré \\
\hline $\begin{array}{l}14 \\
15\end{array}$ & $\begin{array}{l}\text { Laguna } \\
\text { Cond. B. Laguna } \\
\text { Sonda Superm. }\end{array}$ & $\begin{array}{l}\text { Dr. Homem de Melo, } 697 \\
\text { Turiassu, } 2100\end{array}$ & $\begin{array}{l}329400 \\
328500\end{array}$ & $\begin{array}{l}7396170 \\
7397200\end{array}$ & $\begin{array}{l}1992 \\
1993\end{array}$ & $\begin{array}{l}769 \\
729\end{array}$ & $\begin{array}{l}241 \\
102\end{array}$ & $\overline{18}$ & 80 & $\begin{array}{c}1,2 \\
18,4\end{array}$ & $\overline{0,29}$ & $\begin{array}{l}65 \\
76\end{array}$ & $\begin{array}{c}65-70 ; 106-110 \\
31 ; 35 ; 40 ; 44 ; 52 ; \\
65 ; 71 ; 76\end{array}$ & $\begin{array}{l}\text { Frat. } \\
\text { Misto }\end{array}$ & $\begin{array}{l}\text { Sumaré } \\
\text { Pompéia }\end{array}$ \\
\hline 16 & Sesc Pompéia & Clélia, 93 & 328220 & 7397090 & - & 727 & 165 & $\begin{array}{c}9,2 \\
(1993)\end{array}$ & - & $\begin{array}{c}9 \\
(1993)\end{array}$ & - & - & $35 ; 59$ & - & Pompéia \\
\hline 17 & $\begin{array}{l}\text { Tecnon Plásticos } \\
\text { Ltda }\end{array}$ & Joaquim Ferreira, 124 & 328315 & 7397500 & 1978 & 732 & 93 & $\begin{array}{c}8,8 \\
(1992)\end{array}$ & $\begin{array}{c}15,7 \\
(1992)\end{array}$ & $\begin{array}{l}17,6 \\
(1992)\end{array}$ & $\begin{array}{l}2,55 \\
(1992)\end{array}$ & - & - & $\begin{array}{l}\text { Frat. } \\
\text { Sed. }\end{array}$ & $\begin{array}{l}\text { Pompéia } \\
\text { Sumaré }\end{array}$ \\
\hline 18 & $\begin{array}{l}\text { Tecnon Plásticos } \\
\text { Ltda } \\
\text { Váleo Termico }\end{array}$ & $\begin{array}{l}\text { Joaquim Fereira, } 124 \\
\text { Bosque, } 1362\end{array}$ & $\begin{array}{l}328350 \\
330340\end{array}$ & $\begin{array}{l}7397560 \\
7397720\end{array}$ & $\begin{array}{c}1978 \\
-\end{array}$ & $\begin{array}{l}732 \\
722\end{array}$ & $\begin{array}{l}036 \\
175\end{array}$ & $\begin{array}{c}9,3 \\
(1992) \\
127,8 \\
(1992)\end{array}$ & $\begin{array}{c}12,3 \\
(1992) \\
168,6 \\
(1992)\end{array}$ & $\begin{array}{c}10,2 \\
(1992) \\
4,2 \\
(1992)\end{array}$ & $\begin{array}{c}3,4 \\
(1992) \\
0,1 \\
(1992)\end{array}$ & - & - & Frat. & Sumare \\
\hline 21 & $\begin{array}{l}\text { Ltda. } \\
\text { JHS Construção } \\
\text { Planejamento } \\
\text { West Plazza } \\
\text { Shopping }\end{array}$ & $\begin{array}{l}\text { Cel. Melo de Olveira, } 58 \\
\text { Fco. Matarazzo, s/n }\end{array}$ & $\begin{array}{l}328220 \\
329120\end{array}$ & $\begin{array}{l}7396320 \\
7397200\end{array}$ & $\begin{array}{l}1988 \\
1993\end{array}$ & $\begin{array}{l}774 \\
727\end{array}$ & $\begin{array}{l}200 \\
230\end{array}$ & $\begin{array}{c}(1992) \\
13,34 \\
(1991) \\
161\end{array}$ & $\begin{array}{c}85 \\
(1991) \\
181,3\end{array}$ & $\begin{array}{c}0,65 \\
(1991) \\
13,4\end{array}$ & $\begin{array}{c}0,009 \\
(1991) \\
0,67\end{array}$ & $\begin{array}{c}54 \\
108\end{array}$ & $\begin{array}{c}- \\
35 ; 60 ; 70 ; 85 ; 97 \\
102 ; 107\end{array}$ & $\begin{array}{c}\text { Misto } \\
-\end{array}$ & $\begin{array}{l}\text { Sumaré } \\
\text { Sumaré }\end{array}$ \\
\hline $\begin{array}{l}22 \\
23 \\
24 \\
25 \\
26\end{array}$ & $\begin{array}{l}\text { Shopping } \\
\text { Motel Caribe } \\
\text { Clube Palmeiras } \\
\text { Colégio Batista } \\
\text { Motel Caribe } \\
\text { Transporte } \\
\text { looiucatur }\end{array}$ & $\begin{array}{l}\text { Antártica, } 02 \\
\text { Turiassu - Pompéia } \\
\text { Homem de Melo } \\
\text { Antártica, } 02 \\
\text { Motta Paes, } 288\end{array}$ & $\begin{array}{l}329590 \\
328570 \\
329570 \\
329620 \\
326000\end{array}$ & $\begin{array}{l}7397750 \\
7397020 \\
7396060 \\
7397790 \\
7396000\end{array}$ & $\begin{array}{c}1993 \\
1972 \\
1981 \\
- \\
1972\end{array}$ & $\begin{array}{l}721 \\
730 \\
776 \\
721 \\
750\end{array}$ & $\begin{array}{l}405 \\
260 \\
160 \\
344 \\
80\end{array}$ & $\begin{array}{l}153,2 \\
140 \\
- \\
50 \\
15\end{array}$ & $\begin{array}{l}210 \\
190 \\
220 \\
35\end{array}$ & $\begin{array}{c}2 \\
8,3 \\
4 \\
3 \\
12\end{array}$ & $\begin{array}{c}0,035 \\
0,166 \\
- \\
0,02 \\
0,6\end{array}$ & $\begin{array}{c}82 \\
109 \\
- \\
92 \\
70\end{array}$ & $\begin{array}{c}215 ; 227 ; 313 \\
95 ; 102 ; 200 ; 206 \\
- \\
-\end{array}$ & $\begin{array}{l}\text { Frat. } \\
\text { Misto } \\
- \\
\text { Frat. } \\
\text { Sed. }\end{array}$ & $\begin{array}{l}\text { Sumaré } \\
\text { Pompéia } \\
\text { Sumaré } \\
\text { Sumaré } \\
\text { Pompéia }\end{array}$ \\
\hline 27 & $\begin{array}{l}\text { Hospital } \\
\text { Metropolitano }\end{array}$ & Marcelina, 441 & 326880 & 7396720 & 1969 & 768 & 130,8 & 37 & $\begin{array}{c}43 \\
(1993)\end{array}$ & $\begin{array}{r}12 \\
7,5\end{array}$ & 2 & $\begin{array}{l}124 \\
85\end{array}$ & $\begin{array}{c}65 \\
80-112\end{array}$ & $\begin{array}{l}\text { Sedim. } \\
\text { Frat. }\end{array}$ & $\begin{array}{l}\text { Pompéia } \\
\text { Pompéia }\end{array}$ \\
\hline
\end{tabular}

N.E: nivel estático ND: nivel dinåmico Q/s: capacidade específica 
São notáveis as grandes variações dos parâmetros hidrodinâmicos, vazão e capacidade especifica (Tabela 3), denotadas pelos elevados valores dos desvios-padrões, sobretudo nos poços dos sistemas fraturado e misto.

\begin{tabular}{l|c|c|c|c|c|c}
$\begin{array}{c}\text { AQÜÍFERO } \\
\text { CAPTADO }\end{array}$ & \multicolumn{2}{|c|}{ Sedimentar } & \multicolumn{2}{c|}{ Cristalino } & \multicolumn{2}{c}{ Misto } \\
\hline $\begin{array}{l}\text { PARÁMETROS } \\
\text { HIDRODINÂMICOS }\end{array}$ & Q & Q/s & Q & Q/s & Q & Q/s \\
\hline Variação & 2 a 12 & 0,02 a & 1,2 a 17,6 & 0,02 a 2,55 & 0,6 a 18,4 & 0,009 a 1,38 \\
Média & 8,54 & 2 & 6,9 & 0,76 & 8,88 & 0,46 \\
Desvio Padrão & 4,3 & 0,8 & 5,2 & 1,08 & 7,25 & 0,49 \\
\hline
\end{tabular}

Q: Vazão $\left(\mathrm{m}^{3} / \mathrm{h}\right) \quad$ Q/s: Capacidade especifica $\left(\mathrm{m}^{3} / \mathrm{h} \cdot \mathrm{m}\right)$

TABELA 3 - Parâmetros hidrodinâmicos dos poços

As vazões médias são aproximadamente equivalentes nos poços do terreno sedimentar e misto, apresentando uma queda nos poços do aqüifero cristalino.

$O$ volume de água extraído anualmente nos poços do aqüifero sedimentar e misto em operação (5 poços) é de aproximadamente $0,22 \mathrm{Mm}^{3} / a$ no, no sistema cristalino (11 poços) é de $0,32 \mathrm{Mm}^{3} / a n o$, admitindo-se uma operação média dos poços de 12 horas/dia.

O volume de água armazenado no aqüifero sedimentar, considerando-se uma espessura saturada média de 80 metros, porosidade efetiva média de 0,07 (para todo 0 pacote sedimentar), é de aproximadamente $35 \mathrm{Mm}^{3}$.

\subsubsection{A zona não-saturada}

A zona não-saturada é o elo entre os dois ramos da hidrologia: superficial e subterrânea, e corresponde ao local onde se dá o início do processo de recarga.

Devido à urbanização, a zona mais superficial do solo sofreu, na maior parte das vezes, uma descaracterização em diversos graus e a diferentes profundidades, incluindo a compactação, cortes, e aterros com mistura de solos de diferentes granulometrias. Constatouse, durante a perfuração, uma variação das profundidades do aterro sobre o terciário de 0,8 a 2,4 metros (média: $1,30 \pm 0,65 \mathrm{~m}$ ) e no terreno quaternário de 0,8 a 3,20 m (média: $2,09 \pm 1,19$ m).

As permeabilidades na zona não-saturada dos solos nos terrenos terciário e quaternário foram medidas a fim de se estabelecer a velocidade de infiltração direta nestes 
domínios, aproveitando-se a fase inicial da perfuraçäo dos poços de monitoramento. A profundidade média dos trechos ensaiados foi de 2,5 metros, variando de $1,20 \mathrm{~m}$ a $4,20 \mathrm{~m}$, independentemente de tratar-se de aterro ou solo "in situ"

O valor da permeabilidade média em cada trecho ensaiado está representado na Tabela 4. A média geral foi de 3,54-05 $\pm 2,16-05 \mathrm{~cm} / \mathrm{s}$, apresentando 4,10E-05 $\pm 2,37$ E-05 $\mathrm{cm} / \mathrm{s}$ no terreno terciário (Poços $3,5,8,9,11,12,13$ ) e 2,40E-05 $\pm 1,22 \mathrm{E}-05 \mathrm{~cm} / \mathrm{s}$ no terreno quaternário. Os valores obtidos nos testes da zona não-saturada, são compativeis com as litologias atravessadas, como pode ser abservado na Figura 11. Salienta-se que no Poço 10 não foi realizado o ensaio devido aos sucessivos desmoronamentos ocorridos durante a escavação.

\begin{tabular}{|c|c|c|}
\hline POÇo & $\begin{array}{l}\text { TRECHO ENSAIADO } \\
(\mathbf{m})\end{array}$ & $\begin{array}{l}\text { PERMEABILIDADE } \\
(\mathrm{cm} / \mathrm{s})\end{array}$ \\
\hline 1 & $0,0-3,4$ & $3,6 \times 10^{-5}$ \\
\hline 2 & $0,0-2,6$ & $8,3 \times 10^{-6}$ \\
\hline 3 & $0,0-2,2$ & $1,4 \times 10^{-5}$ \\
\hline 4 & $0,0-2,4$ & $3.1 \times 10^{-5}$ \\
\hline 5 & $0,0-2,4$ & $1.8 \times 10^{-5}$ \\
\hline 6 & $0,0-1,9$ & $7.5 \times 10^{-5}$ \\
\hline 7 & $0,0-1,3$ & $2,1 \times 10^{-5}$ \\
\hline 8 & $0,0-2,0$ & $6.7 \times 10^{-5}$ \\
\hline 9 & $0,0-2,5$ & $5,8 \times 10^{-5}$ \\
\hline 11 & $0,0-4,2$ & $3,6 \times 10^{-5}$ \\
\hline 12 & $0,2-1,4$ & $4,2 \times 10^{-5}$ \\
\hline 13 & $0,0-2,0$ & $1.8 \times 10^{-5}$ \\
\hline $\begin{array}{c}\text { Média } \\
\text { Desvio Padrão }\end{array}$ & & $\begin{array}{l}3,54 \times 10^{-5} \\
2,16 \times 10^{-6}\end{array}$ \\
\hline
\end{tabular}

TABELA 4 - Resultado dos Ensaios de Permeabilidade 
Argilas siltosas. areia fina argilosa. argilas siltosas. argilas . alteração de rocha

Cascalho arenoso Areia grossa bem selecionada

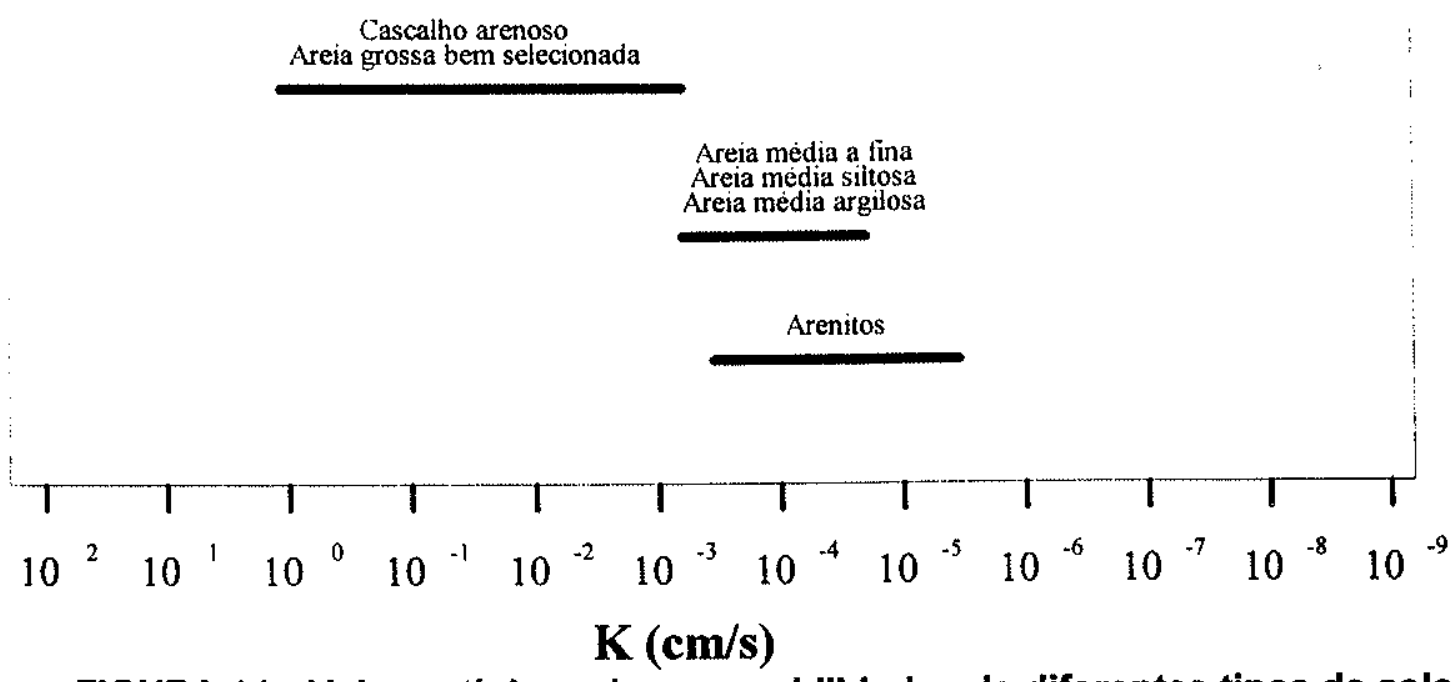

FIGURA 11 - Valores típicos de permeabilidades de diferentes tipos de solos (adaptado de Bowies, 1984 e Walton, 1988) 


\section{ESTUDO DA RECARGA AQÜÍFERA}

A medida da recarga total no aqǘfero freático correspondeu à soma dos incrementos da recarga direta, ou da precipitação, e da recarga indireta. Dadas as dificuldades do estudo nas em decorrência da intensa ocupação urbana, algumas considerações e ponderações foram feitas, para tornar exeqüivel o estudo da recarga proposto, assim resumidas:

- a bacia representa um sistema fechado, onde as saidas hidricas eventualmente existentes para outros sistemas laterais, são compensadas por eventais entradas:

- as duas sub-bacias, Sumaré e Pompéia, foram consideradas indiscriminadamente como uma só bacia, uma vez que as mesmas são contiguas e possuem caracteristicas semelhantes de ocupação urbana, geologia e fisiografia;

- a precipitação foi considerada uniforme por toda a área de abrangência da bacia.

\subsection{ANÁLISE PRELIMINAR DOS COMPONENTES DO SISTEMA HIDROLÓGICO}

Neste item são apresentados estudos preliminares relacionados à caracterização do comportamento de componentes do sistema hidrológico (água infiltrada e precipitação), monitorados no curso de um ano, bem como à estimativa da taxa impermeável. Esses estudos permitiram a avaliação da recarga direta e uma maior compreensão da sua dinâmica nos aqüiferos freáticos. Os tópicos abordados foram os relativos à:

- precipitação ocorrida durante o periodo hidrológico em questão;

- comportamento das nascentes;

- comportamento dos niveis freáticos;

- velocidade de infiltração, e

- estimativa da área impermeável

\subsubsection{Precipitação}

No estudo estimativo da recarga, foram adotados os dados da Estação Água Branca, por apresentar um índice de leituras de $99 \%$, no período considerado.

O total precipitado durante o periodo hidrológico de um ano (out/94 a set/95) foi de $1818 \mathrm{~mm}\left(17,4 \mathrm{Mm}^{3}\right)$. A distribuiçăo dos volumes precipitados no terreno terciário foi de 11,6 $\mathrm{Mm}^{3}$ e no terreno quaternário, de $5,8 \mathrm{Mm}^{3}$ (Tabela 5). 


\begin{tabular}{lcc} 
AQUífERO & $\begin{array}{c}\text { ÁREA } \\
\left(\mathbf{K m}^{2}\right)\end{array}$ & $\begin{array}{c}\text { VOLUME } \\
\text { PRECIPITADO } \\
\left(\mathbf{M m}^{3}\right)\end{array}$ \\
\hline Terciário & 6,4 & 11,6 \\
Quaternário & 3,2 & 5,8 \\
\hline Total & 9,6 & $\mathbf{1 7 , 4}$ \\
\hline
\end{tabular}

TABELA 5 - Volumes precipitados na área

As precipitações mensais ocorridas durante o ciclo hidrológico em estudo foram comparadas às médias mensais plurianuais, da série de 13 anos (1980 1992), conforme representado na Figura 12, onde é possível constatar os altos índices pluviométricos nos meses úmidos do ciclo considerado (1994/1995), em relação às médias da série.

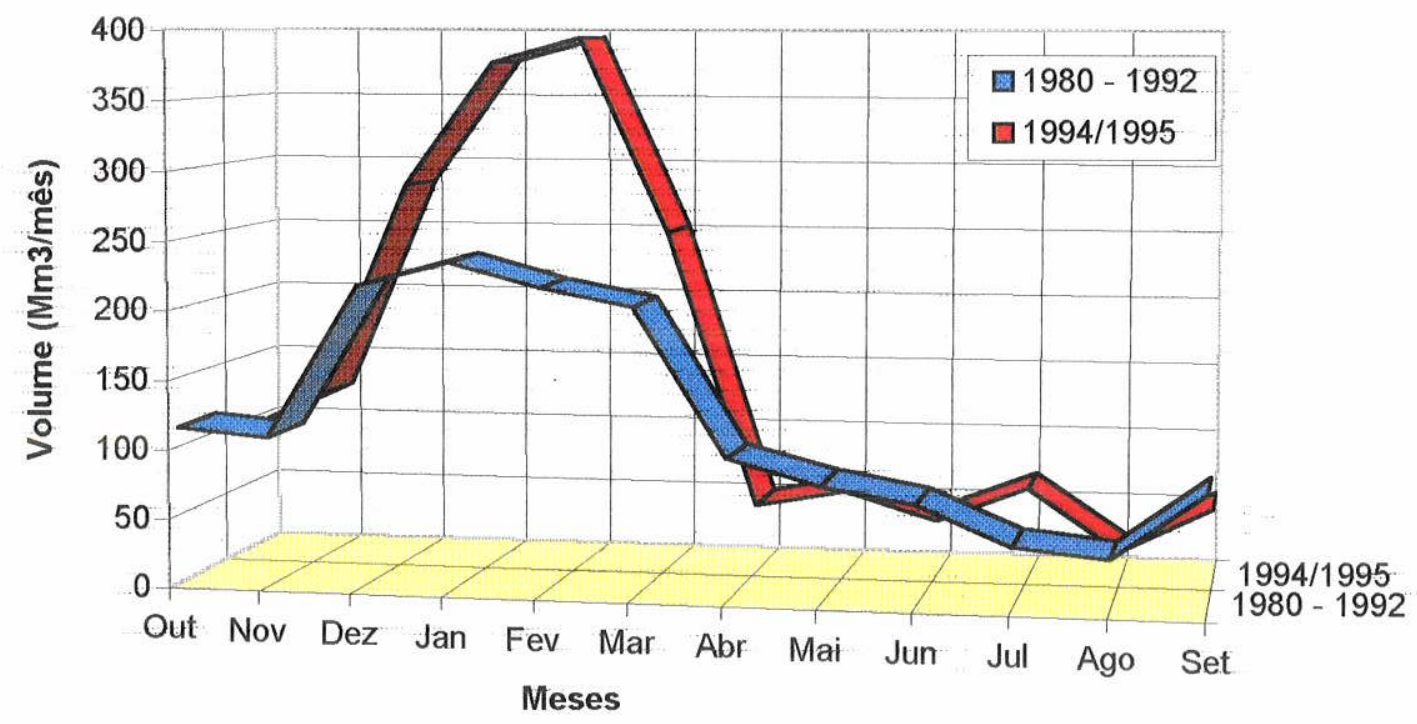

FIGURA 12 - Precipitação mensal plurianual (1980 a 1992) e mensal (1994/1995) 


\subsubsection{Comportamento das nascentes}

As nascentes são encontradas no terreno terciário, acima da cota 740 , tendo sido plotadas no mapa fisiográfico (Figura 6) e geológico local (Figura 8). O objetivo do controle das vazões das nascentes foi a avaliação qualitativa da dinâmica dos fluxos do aqüifero freático.

O monitoramento das vazöes foi realizado na mesma freqüência das medições dos niveis d'água, ou seja, a cada 30 dias, com intervalos de 15 dias no periodo úmido (Tabela 6).

\begin{tabular}{|c|c|c|c|c|c|c|c|c|}
\hline NASCENTE & 1 & 2 & 3 & $4^{\prime \prime}$ & $5^{*}$ & $6^{*}$ & 7 & 8 \\
\hline COTA & 765 & 765 & 765 & 769 & 750 & 790 & 740 & 740 \\
\hline LOGAL & SUMARE-1 & SUMARE-2 & Mln. GODOY & P. VIEIRA & CAJAÍBA & $\begin{array}{l}\text { D. JOÄO } \\
\text { V. }\end{array}$ & $\begin{array}{c}\text { AGUA } \\
\text { BRANCA-1 }\end{array}$ & $\begin{array}{c}\text { AGUA } \\
\text { BRANCA-2 }\end{array}$ \\
\hline DATA & & & & VAZÁO $(\mathrm{l} / \mathrm{h})$ & & & & \\
\hline $21 /$ out/94 & 236.00 & 139.00 & $=$ & 589.00 & 531.00 & 100.00 & 1440.00 & 553.80 \\
\hline 22/nov/94 & 377.00 & 206.40 & - & 605.00 & 522.00 & 128.00 & 2700.00 & 426.30 \\
\hline 06/dez/94 & 476.00 & 163.60 & - & 648.00 & 600.00 & 156.00 & 4628.00 & 852.60 \\
\hline 19/dez/94 & 648.00 & 171.40 & - & 810.00 & 720.00 & 360.00 & 2160.00 & 736.40 \\
\hline 03/jan/95 & 648.00 & 219.80 & 155.00 & 953.00 & 689.00 & 753.00 & 1906.00 & 1045.20 \\
\hline 23/jan/95 & 648.00 & 216.00 & 81.80 & 852.00 & 675.00 & 506.00 & 2492.00 & 469.60 \\
\hline 13/fev/95 & 810.00 & 229.80 & 270.00 & 1296.00 & 875.00 & 1906.00 & 8100.00 & 1117.20 \\
\hline 06/mar/95 & 720.00 & 202.50 & 139.60 & 1045.00 & 831.00 & 1117.00 & 6480.00 & 623.10 \\
\hline 21/mar/95 & 611.00 & 198.00 & 105.00 & 1045.00 & 753.00 & 771.00 & 4629.00 & 790.20 \\
\hline 11/abr/95 & 648.00 & 202.50 & 100.00 & 1080.00 & 753.00 & 900.00 & - & 483.00 \\
\hline 25/abr/95 & 623.00 & 102.90 & 85.70 & 853.00 & 690.00 & 504.00 & 2880.00 & 611.00 \\
\hline 25/mai/95 & 462.90 & 180.00 & 60.00 & 926.00 & 589.00 & 52.00 & 4628.60 & 589.10 \\
\hline 26/jun/95 & 498.50 & 180.00 & 42.00 & 926.00 & 589.00 & SECO & - & - \\
\hline 26/u//95 & 410.10 & 176.00 & - & 810.00 & 579.00 & SECO & - & - \\
\hline $25 /$ agd/95 & 423.50 & 157.40 & - & 778.00 & 576.00 & SECO & - & - \\
\hline $22 / \operatorname{set} / 95$ & 405.60 & 171.40 & - & 689.00 & 540.00 & SECO & - & - \\
\hline
\end{tabular}

\section{TABELA 6 - Vazões das nascentes}

Mediu-se, in situ, as concentrações dos parâmetros Cloro livre e Fluoreto para constatação da origem da água (meteórica ou de vazamentos da rede de abastecimento). Cloro livre é considerado o mais indicativo para a finalidade proposta, uma vez que o mesmo não é encontrado naturalmente, como no caso do Flúor $(0,1 \mathrm{ppm}$, em média). A concentração do Flúor seria considerada somente mediante a constatação da presença do Cloro livre, constituindo, portanto, numa forma de aferição adicional sobre a origem por vazamentos.

Foram tomadas, ao todo, 20 medições de cada um dos dois parâmetros acima relacionados, entre quatro nascentes, consideradas mais confiáveis (Nascentes $n^{28} 1,4,5,6$ ), encontrando-se o seguinte resultado para o Flúor: não foi detectado em três medições; sete medições apresentaram concentração entre 0,01 e 0,1 ppm; e em dez medições os valores oscilaram entre $0,1-0,47 \mathrm{ppm}$, sendo que destes dez nove estão entre 0,1-0,27 ppm. Em 
relação ao Cloro livre, não foi constatada a presença deste parâmetro em nenhuma das análises realizadas, confirmando, portanto, a origem meteórica destas águas.

O monitoramento das vazões em oito nascentes, mostraram que as mesmas são, em geral, perenes, sofrendo uma redução da vazão na estação seca (abril a setembro), de 40 a $55 \%$ em relação à vazão máxima, em Fevereiro (as mediçōes encontram-se na Tabela 6).

O estreito controle da precipitação sobre as vazões é constatado na Figura 13 , onde estão representadas as nascentes mais confiáveis ( $n^{0 \text { s }} 4,5$ e 6), sob o aspecto de interferência antrópica e com maior número de leituras.

As constatações acima relacionadas refletem condições hidráulicas favoráveis à dinâmica e à percolação da precipitação, nas camadas mais superficiais da formação São Paulo, descobertas da impermeabilização. A percolação nestas áreas é garantida pelo perfil litológico (laterítico), constituido de camadas predominantemente argilosas sotopostas a lentes mais arenosas. O nivel freático possui normalmente uma profundidade menor que 4,0 $m$ (Figura 10), constituindo os aqüiferos suspensos.

A partir destes dados, pressupõe-se que uma grande parte dos fluxos infitrados nestas áreas sofre descarga local, com insignificante contribuição para as zonas mais profundas do aqüif́tero. 

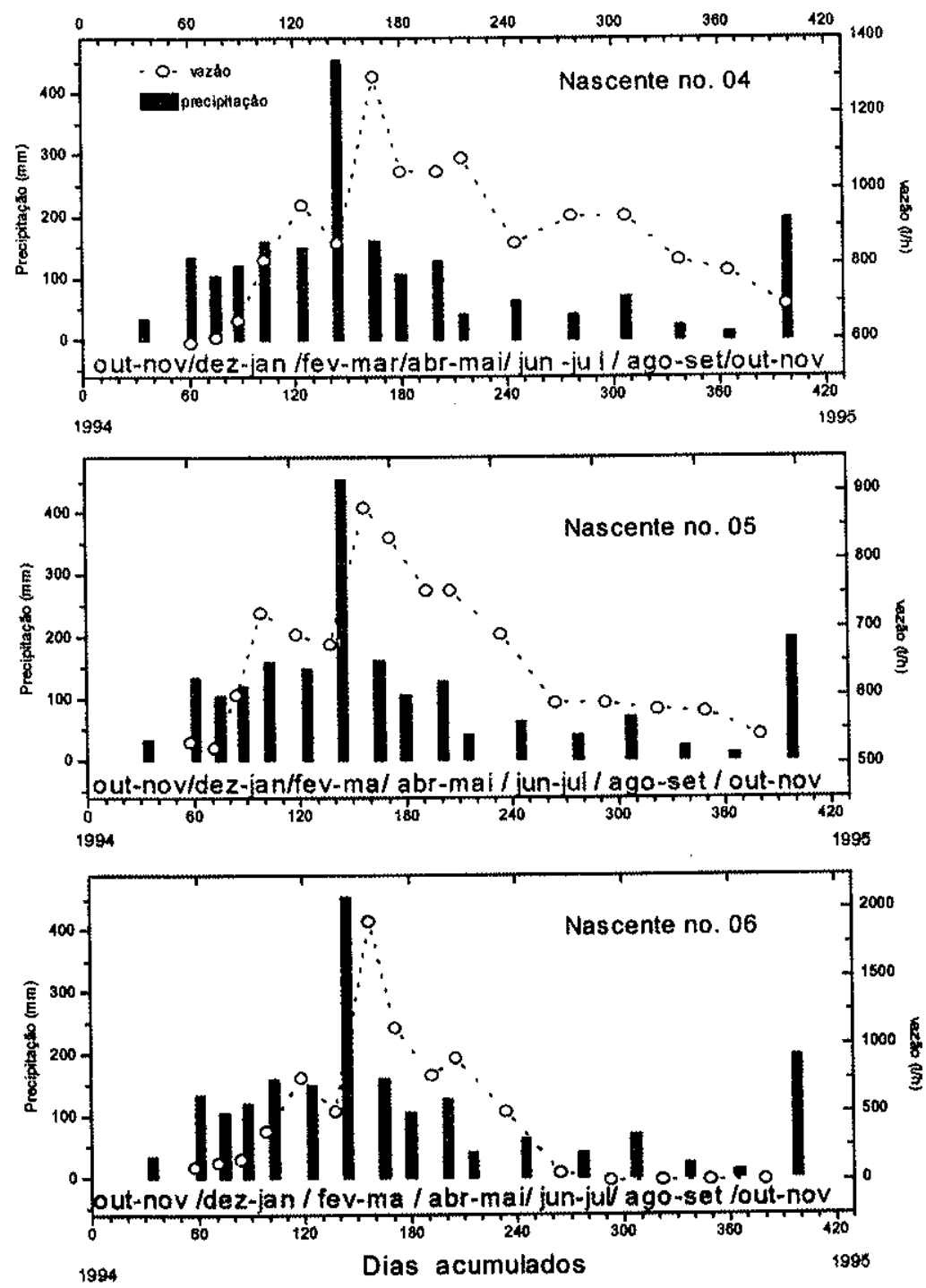

Figura 13 - Precipitação e vazão das nascentes

\subsubsection{Comportamento do nível freático}

O comportamento dos nível freático foi caracterizado visando a:

- avaliar o grau de influência da precipitação sobre as variações do nivel d'água;

- estimar o tempo real de percolação vertical da infiltração natural, e a velocidade de infiltração média vertical na zona não saturada, e 
- estimar as espessuras saturadas médias resultantes da infiltração natural.

Os dados de campo do nivel freático para cada poço são apresentados nas planilhas do Anexo 3, para o periodo de monitoramento.

$\mathrm{Na}$ Tabela 7 encontram-se relacionadas a localização e profundidade dos poços de monitoramento, bem como a profundidade do nivel freático no mês de setembro/94, mês anterior ao inicio do monitoramento.

\begin{tabular}{|c|c|c|c|c|c|}
\hline Poço & LOCALIZAÇÃo & SUB-BACIA & $\begin{array}{l}\text { PROFUNDIDADE } \\
\text { TOTAL }(m)\end{array}$ & $\begin{array}{l}\text { "PROFUNDI } \\
\text {-DADE DO } \\
\text { N.A. (m) }\end{array}$ & $\begin{array}{l}\text { COTA } \\
\text { (m) }\end{array}$ \\
\hline 1 & Ponte do Limão - B. Funda & Sumaré & 4,65 & 3,45 & 723 \\
\hline 2 & Pça. Pascoal Martins - B. Funda & Pompéia & 3,40 & 3,40 & 722 \\
\hline 3 & Pça. C. F. Matarazzo - Água Branca & Sumaré & 9,20 & 7,60 & 732 \\
\hline 4 & Rua da Várzea - B. Funda & Sumaré & 4,50 & 3,60 & 722 \\
\hline 5 & Praça Cornélia - V. Romana & Pompéia & 8,30 & 7,60 & 743 \\
\hline 6 & Pque. Água Branca - Água Branca & Sumaré & 3,80 & 1,92 & 741 \\
\hline 7 & Nacional Atlético Clube - Lapa & Pompéia & 3,50 & 1,30 & 721 \\
\hline 8 & Pça. Jesuíno Bandeira - Siciliano & Pompéia & 4,40 & 2,00 & 751 \\
\hline 9 & Pça irmãos Karman - Sumaré & Sumaré & 5,10 & 2,40 & 756 \\
\hline 10 & R. Olavo Freire - Sumaré & Sumaré & 12,0 & 6,00 & 791 \\
\hline 11 & Pça Dr. Vicente - Jd. Vera Cruz & Pompéia & 8,40 & 4,40 & 762 \\
\hline 12 & Pça. Homero Silva - Pompéia & Pompéia & 3,90 & 1,40 & 775 \\
\hline 13 & EMEI Santos Dumont - Pompéia & Pompéia & 10,10 & 8,75 & 750 \\
\hline
\end{tabular}

Verificou-se uma nítida e estreita relação da precipitação com as variações do nível freático (Anexo 4). O período de ascensão iniciou-se em outubro/94 alcançando um pico máximo em fevereiro/95. Este intervato correspondeu ao periodo de maior volume precipitado, tendo chovido nestes 5 meses $1252 \mathrm{~mm}$, isto é $69 \%$ da precipitação total durante o ciclo de 12 meses, encerrado em setembro/95, que foi de $1818 \mathrm{~mm}$.

Apesar do período chuvoso ter se prolongado até março/95, os níveis foram sofrendo uma recessão já a partir deste mês, apresentando impulsos de recuperação devido à ocorrência de precipitações menos freqüentes, durante os meses seguintes, até o final do ciclo, em setembro/95.

As respostas do nivel freático às precipitações, são, em geral, mais nítidas nos poços mais rasos, como observado nos Poços $4,6,7,8,9$ e 12, nos quais verificam-se picos proeminentes de variação de nível, antecedidos por picos de chuva. Isto ocorre devido ao menor período decorrido desde o instante da precipitação até o instante da chegada da água nos niveis mais rasos.

O mês de setembro/95 finaliza o ciclo hidrológico de 12 meses. No mês de outubro/95 nota-se uma recuperação dos níveis, quando da incidência de precipitações a partir do final de setembro/95, denotando o inicio de uma nova estação úmida. 
Em $75 \%$ dos poços, correlações entre as precipitações e as profundidades do nivel d'água resultaram num coeficiente elevado entre estes parâmetros, com média de $-0,84$ (valores entre $-0,71$ e $-0,99$ ), e erros bastante baixos, menores de 0,05 (Tabela 8 ). Os que não obtiveram um bom coeficiente de correlação foram os Poços 8,10 e 12, em destaque na Tabela, verificando-se, porém, um baixo erro para os poços Poços 10 e $12(<0,08)$. Os Poços 10 e 12 estão associados a niveis suspensos, junto às nascentes 6 e 4 .

\begin{tabular}{|c|c|c|c|c|}
\hline POÇO & $\mathbf{r}$ & $\mathbf{p}$ & sd & $\mathbf{n}$ \\
\hline 01 & $-0,95712$ & $2,94 \mathrm{E}-07$ & 0,23525 & 13 \\
\hline 02 & $-0,99055$ & 2,67E-07 & 0,04963 & 09 \\
\hline 03 & $-0,73202$ & $4,44 E-03$ & 0,15054 & 13 \\
\hline 04 & $-0,88207$ & 1,50E-04 & 0,09206 & 12 \\
\hline 05 & $-0,88589$ & 6,00 E-05 & 0,31912 & 13 \\
\hline 06 & $-0,86000$ & $1,20 E-04$ & 0,04457 & 13 \\
\hline 07 & $-0,76201$ & $2,46 \mathrm{E}-03$ & 0,09877 & 13 \\
\hline 08 & $-0,37048$ & $2,10 E-01$ & 0,04457 & 13 \\
\hline 09 & $-0,78514$ & $1,47 \mathrm{E}-03$ & 0,07885 & 13 \\
\hline 10 & $-0,49516$ & $8,53 E-02$ & 0,29450 & 13 \\
\hline 12 & $-0,56946$ & $4,22 E-02$ & 0,20531 & 13 \\
\hline 13 & $-0,71626$ & $5,89 \mathrm{E}-03$ & 0,20531 & 13 \\
\hline & 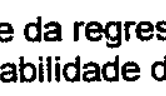 & & dadc & \\
\hline
\end{tabular}

TABELA 8 - Correlação entre a profundidade do nível d'água e precipitação mensal.

As espessuras saturadas totais, resultantes de todos os incrementos de infiltração durante o ciclo considerado (out/94 a set/95) e registrados nos poços de monitoramento (Anexo 3), foram calculadas para os dois domínios hidrogeológicos: o terciário (nivel freático mais profundo e nivel mais raso) e o quaternário.

No aqüifero terciário foi registrada uma espessura média saturada/ano de 1,93 $\pm 0,61$ $m$ nos quatro poços de mais profundos deste domínio, e de $\mathbf{0 , 8 0} \pm 0,21 \mathrm{~m}$ nos quatro poços mais rasos.

No aqüifero quaternário a espessura saturada média anual foi de $1,61 \pm 0,93 \mathrm{~m}$, bastante superior, portanto, à resgistrada nos niveis mais rasos do aqüifero terciário.

\subsubsection{Velocidade de infiltração vertical}

E notória a defasagem de tempo decorrido entre os picos máximos de chuva e os picos máximos de recuperação dos níveis freáticos. Esta defasagem representa, em termos 
gerais, o tempo compreendido entre a precipitação e a chegada do fluxo até o aqülfero freático.

Os tempos de resposta foram calculados para a obtenção da velocidade de percolação, em termos médios.

Dado que os poços monitorados encontram-se em dois diferentes contextos hidrogeológicos, e que, também interceptam diferentes profundidades do nivel d'água no dominio do aqüífero sedimentar terciário, os poços foram reunidos segundo estes parâmetros, em três grupos, da seguinte forma:

\section{Aqüifero sedimetar terciário:}

1) Poços mais rasos, com profundidades do nivel d'água $<4,0 \mathrm{~m}$ (Poços $6,8,9$ e 12).

2) Poços mais profundos, com profundidades do nivel d'água entre 5,5 e $8,5 \mathrm{~m}$ (Poços 3,5 , 10 e 13).

\section{Aqüifero sedimentar quatemário:}

3) Poços com profundidades do nivel d'água $<4,0 \mathrm{~m}$ (Poços 1, 2, 4, e 7), isto é, todos os poços ai perfurados.

Comparando-se os três grupos, verificou-se que o grau de correlaçäo entre a precipitação e a profundidade do nível d'água, visto na Tabela 7 , é mais elevado para os poços perfurados nos sedimentos quaternários (média: 0,85 ). Tal fato pode ser explicado pela menor taxa impermeável relativa, com maiores áreas disponiveis à infiltração direta.

No terreno terciário observou-se que, dentre os poços com nivel d'água mais rasos, dois apresentaram um bom índice de correlação, com média de 0,82 (Poços 6 e 9), enquanto outros dois (Poços 8 e 12) apresentam coeficientes bastante baixos, com média 0,47. No. grupo de poços com nivel d'água mais profundos a correlação foi superior a 0,7 (média 0,71 ), com apenas um poço apresentando baixo coeficiente (Poço 10), igual a 0,49 , porém com baixo erro estatístico $(0,0085)$.

Os poços com baixo coeficiente de correlação situam-se em locais de elevado declive, cuja condição permite uma maior influência de fluxos adjacentes. Observou-se, ainda, que os Poços 10 e 12 (de baixa correlação), localizam-se em locais de descarga, como atestado pela presença de duas nascentes ( $n^{\text {os }} 6$ e 4 , respectivamente), adjacentes a estes poços.

Para obtenção de resultados os mais confiáveis possível, os cálculos das velocidades de infiltração foram realizados separadamente para os dois grupos de poços, sendo aplicadas duas formas de cálculo. $O$ intervalo de tempo quinzenal e mensal entre as medições permitiu o cálculo do tempo médio de resposta, utilizando-se os procedimentos explanados a seguir: 
(1) a partir das mediçōes quinzenais e mensais dos niveis d'água -

Os dados das medições quinzenais e mensais foram aplicados apenas aos poços mais profundos do aqüífero sedimentar terciário ( $n^{\text {os }} 3,5,10$ e 13), devido ao maior percurso vertical de percolação do fluxo, além do fato do coeficiente de correlação precipitação profundidade do nível d'água neste grupo de poços ser relativamente elevado $(0,71)$.

Foi calculada, para cada poço, a velocidade média de resposta do nivel d'água, a partir de cada trecho do gráfico Profundidade do nivel d'água $x$ Tempo, que apresentou variação positiva entre duas medições consecutivas ao longo do periodo monitorado (Anexo 4).

A velociade média geral, correspondente à condutividade hidráulica vertical, foi obtdia pela média das velocidades médias calculadas para cada poço. $O$ valor encontrado foi de $0,38 \mathrm{~m} / \mathrm{dia}(4,4 \mathrm{E}-04 \mathrm{~cm} / \mathrm{s})$, do que resulta num tempo médio de resposta de $19 \pm 1,1$ dias empregando-se a profundidade média do nivel d'água de 7,30 $\mathrm{m}$ (Tabela 9 ).

A partir deste valor de velocidade, encontrada pelos dados do poços profundos, obteve-se para os poços mais rasos, um tempo de resposta médio de aproximadamente $5 \pm$ 1,6 dias.

\begin{tabular}{lccc} 
POÇO & $\begin{array}{c}\text { PROF. MÉDIA } \\
\text { N.A. } \\
(\mathbf{m})\end{array}$ & $\begin{array}{c}\text { VELOCIDADE } \\
\text { MÉDIA } \\
\text { (cm/seg) }\end{array}$ & $\begin{array}{c}\text { TEMPO MÉDIO } \\
\text { DE RESPOSTA } \\
\text { (Dias) }\end{array}$ \\
\hline 3 & 7,24 & $4,39 E-04$ & 19 \\
5 & 6,97 & $3,77 \mathrm{E}-04$ & 21 \\
10 & 7,10 & $4,25 \mathrm{E}-04$ & 19 \\
13 & 7,87 & $5,16 \mathrm{E}-04$ & 18 \\
\hline MÉDIA & $\mathbf{7 , 3 0}$ & $\mathbf{4 , 4 0 E - 0 4}$ & 19 \\
\hline $\begin{array}{l}\text { DESVIO PADRAO } \\
\text { (sd) }\end{array}$ & 0,34 & $5,0 \mathrm{E}-05$ & 1,1 \\
\hline
\end{tabular}

TABELA 9 - Velocidade média de infiltração e tempo de resposta (medições quinzenais e mensais).

\section{(2) a partir das medições dos niveis d'água de $4 \mathrm{em} 4$ dias}

Estas medições, realizadas somente nos poços do aqüífero terciário, entre 22 de setembro/94 a 03/novembro/95 (Anexo 5), permitiram estimar, o valor da velocidade de percolação vertical nos locais de maior e menor profundidades do nivel freático. Foram utilizados neste caso os registros de todos os poços de monitoramento deste aqüifero $\left(\mathrm{n}^{\circ \mathrm{s}} 3\right.$, $5,6,8,9,10,12$ e 13$)$.

Destaca-se que estas medições iniciaram-se após 37 dias desprovidos de chuva, contribuindo, desta forma, para maior credibilidade e precisão dos tempos de respostas medidos. 
Realizou-se uma correlação entre a precipitação e a resposta do nível freático para precipitações diárias ocorridas durante o intervalo de medições diárias e para precipitações acumuladas nos 44 dias de monitoramento (Tabela 10).

Os resultados mostraram que, para o caso das precipitações diárias, o coeficiente é muito baixo $(0,18$ a 0,53$)$, entretanto, para a precipitação acumulada, obtém-se uma média de $0,90 \pm 0,007$, com exceção apenas do poço PM-06.

Estes resultados indicam:

- a influência das chuvas antecedentes sobre um novo incremento de infiltração e recarga;

- um tempo de resposta de, não menor do que 4 dias para todos os poços, e

- pode haver variações locais que não seguem o comportamento geral, como o verificado no poço PM-06.

\begin{tabular}{|c|c|c|c|}
\hline $\begin{array}{l}\text { CLASSE DOS } \\
\text { POÇOS }\end{array}$ & POÇOS & $r_{1}$ & $r_{2}$ \\
\hline MAIS PROFUNDOS & $\begin{array}{l}P M-03 \\
P M-05 \\
P M-10 \\
P M-13\end{array}$ & $\begin{array}{l}0,95 \\
0,93 \\
0,79 \\
0,96\end{array}$ & $\begin{array}{l}0,30 \\
0,27 \\
0,53 \\
0,18\end{array}$ \\
\hline MAIS RASOS & $\begin{array}{l}\text { PM-06 } \\
\text { PM-08 } \\
\text { PM-09 } \\
\text { PM-12 } \\
\end{array}$ & $\begin{array}{l}0,21 \\
0,96 \\
0,92 \\
0,72 \\
\end{array}$ & $\begin{array}{l}0,45 \\
0,29 \\
0,34 \\
0,28 \\
\end{array}$ \\
\hline$r_{1}:$ para precipitaça & mulada $r_{2}$ & recipitaca & de med \\
\hline
\end{tabular}

Para a leitura dos tempos de resposta do nivel d'água à precipitação (Anexo 5), foram assumidos os seguintes critérios:

\section{Pocos com nivel d'áqua mais profundos}

Assumiu-se como tempo médio de resposta o intervalo entre a data do primeiro evento de precipitação (ocorrido a 13 de setembro/95) e a data de leitura da primeira resposta positiva do nivel d'água, nos respectivos poços. Considerando-se, porém, que a data real da chegada do fluxo ao nivel d'água não pôde ser precisamente detectada, o tempo de resposta foi calculado como o equivalente à média entre os dois extremos do trecho representativo no gráfico.

Obteve-se um tempo médio de resposta de $14 \pm 2,9$ dias, a partir do qual calculou-se a velocidade média, $0,55 \mathrm{~m} / \mathrm{dia}(6,40 \mathrm{E}-04 \mathrm{~cm} / \mathrm{s})$, Tabela 11 .

Constatou-se ainda que o tempo de resposta encontra-se relacionado com a profundidade do nível d'água, com índice médio de correlação de 0,96. 


\begin{tabular}{c|c|c|c|c} 
POÇO & $\begin{array}{c}\text { PROFUNDIDADE } \\
\text { MÉDIA DO N. A. } \\
(\mathbf{m})\end{array}$ & $\begin{array}{c}\text { INTERVALO } \\
\text { (DIAS) }\end{array}$ & $\begin{array}{c}\text { *TEMPO MÉdIO } \\
\text { (DIAS) }\end{array}$ & $\begin{array}{c}\text { VELOCIDADE } \\
\text { (cm/s) }\end{array}$ \\
\hline 3 & 7,24 & $13-16$ & 14,5 & $5,78 E-04$ \\
5 & 6,97 & $9-13$ & 11 & $7,33 E-04$ \\
10 & 7,47 & $9-13$ & 11 & $7,47 E-04$ \\
13 & 7,87 & $16-20$ & 18 & $5,06 E-04$ \\
\hline MEDIA & $\mathbf{7 , 3 0}$ & & 14 & $6,40 E-04$ \\
\hline DESVIO PADRAO & & & 2,9 & $1,18 E-04$ \\
\hline (sd) & 0,33 & &
\end{tabular}

- obtido a partir do gráfico

TABELA 11 - Velocidade de infiltração e tempo de resposta (medições de 4 em 4 dias).

\section{Pocos com nivel d'áqua mais rasos}

Nas leituras com intervalo de 4 dias observou-se um comportamento bastante diferenciado entre o grupo de poços com niveis d'água mais rasos e os mais profundos.

Enquanto nos níveis mais profundos a recarga inicial ocorre de forma menos expressiva, só atingindo maior significância após vários dias desde o início das chuvas, nos poços mais rasos, com níveis d'água entre 1,08 e $2,77 \mathrm{~m}$, os picos de resposta são mais proeminentes, já próximo das primeiras chuvas, devido ao menor tempo de resposta.

Se fosse adotado o mesmo critério como no caso dos niveis mais profundos, encontrariamos um tempo de resposta de 13 dias, o que seria irreal, comparando-se com o tempo obtido para os poços mais profundos, que foi de aproximadamente 14 dias. Isto ocorre provavelmente por falta de registro, devido ao grande intervalo de tempo (9 dias), entre a primeira chuva (13/set/95) e a primeira leitura (22/set/95).

Como as respostas destes niveis são mais imediatas, estimou-se o tempo de resposta a partir da diferença entre a data do primeiro pico de resposta e o primeiro pico anterior de chuva, do que resultou num tempo de resposta médio de 5 dias. As variações das profundidades destes níveis, devem provocar também, variações nos tempos de resposta, porém, os intervalos de medição adotados não permitiram uma precisão que apontasse tais variações.

Em sintese, as velocidades de percolação e os tempos de resposta calculados pelas duas formas de análise (mensais/quinzenais e a cada 4 dias) apresentaram valores diferentes, mas não discrepantes, principalmente levando-se em conta os valores dos desvios padrões.

Nos poços com níveis d'água mais profundos, as velocidades obtidas por meio das leituras mensais e quinzenais dos foi de $0,38 \mathrm{~m} /$ dia e por meio das leituras de $4 \mathrm{em} 4$ dias foi de $\mathbf{0 , 5 5} \mathrm{m} / \mathrm{dia}$. A média ponderada destes vaiores em relação aos seus desvios padrões foi 
de $\mathbf{0 , 5 0} \mathrm{m} /$ dia, que representa velocidade superior de uma ordem de grandeza em relação à obtida por meio dos ensaios de infiltração efetuados em campo, que foi de $\mathbf{0 , 0 3} \mathrm{m} / \mathrm{dia}(\mathbf{3 , 5 4 E}$ $05 \mathrm{~cm} / \mathrm{seg}$ ).

A velocidade de $0,50 \mathrm{~m} /$ dia foi considerada como mais representativa, pois esta foi obtida a partir de uma série de medições nas condições reais, abrangendo todo o trecho acima do nivel d'água. Além disso, no caso do ensaio de infiltração, os procedimentos de campo podem introduzir erros, como a colmatação por material argiloso nas paredes do furo, mesmo após a sua escarificação, diminuindo a velocidade de infiltração.

Por intermédio das medições mensais, o tempo médio de resposta encontrado para os niveis mais profundos foi de $19 \pm 1,1$ dias, enquanto que por medições de 4 em 4 dias, foi de $14 \pm 2,9$ dias, tendo com média ponderada em relação aos seus desvios padrões, um tempo médio de 15 dias. Com relação aos níveis mais rasos, tanto pelas medições mensais, quanto a cada 4 dias, o tempo médio de resposta calculado foi de 5 dias.

\subsubsection{Estimativa da área impermeável}

Considerou-se áreas impermeáveis, aquelas ocupadas pelas construções (residenciais, industriais, comerciais e parques de estacionamentos), pelas pavimentações domiciliares (pátios cimentados, garagens externas, etc.) e pela pavimentação viária.

A estimativa da área impermeável foi realizada para cada um dos dois terrenos geológicos, o terciário e o quaternário, sendo a ocupação bastante diferenciada nestes dois terrenos: mais adensada no terreno terciário, com predomínio residencial e comercial, e menos adensada no domínio quaternário, com ocupação industrial e de recreação.

Em termos do zoneamento urbano delimitado pela PMSP, existem sete zonas de ocupação para toda a área, e que para simplificação, foram agrupadas em apenas cinco, com base na semelhança entre si (Figura 14). Em termos gerais, estas zonas podem ser caracterizadas de acordo com o tipo e aproveitamento máximo de ocupação (porcentagem da área construída, em projeção vertical, em relação à área do terreno), de acordo com a legislação municipal vigente, da seguinte forma:

- $Z_{1}$ - residencial horizontal, comércio extremamente restrito a ausente, com aproveitamento máximo de $40 \%$.

- $Z_{2}$ - residencial, comercial e serviços, com aproveitamento máximo permitido de $50 \%$.

- $Z_{3}$ - residencial, comercial e serviços de maior porte que $Z_{2}$, com aproveitamento máximo permitido de $50 \%$.

- $\mathrm{Z}_{6}$ - industrial e comercial, com aproveitamento máximo permitido de $70 \%$. 


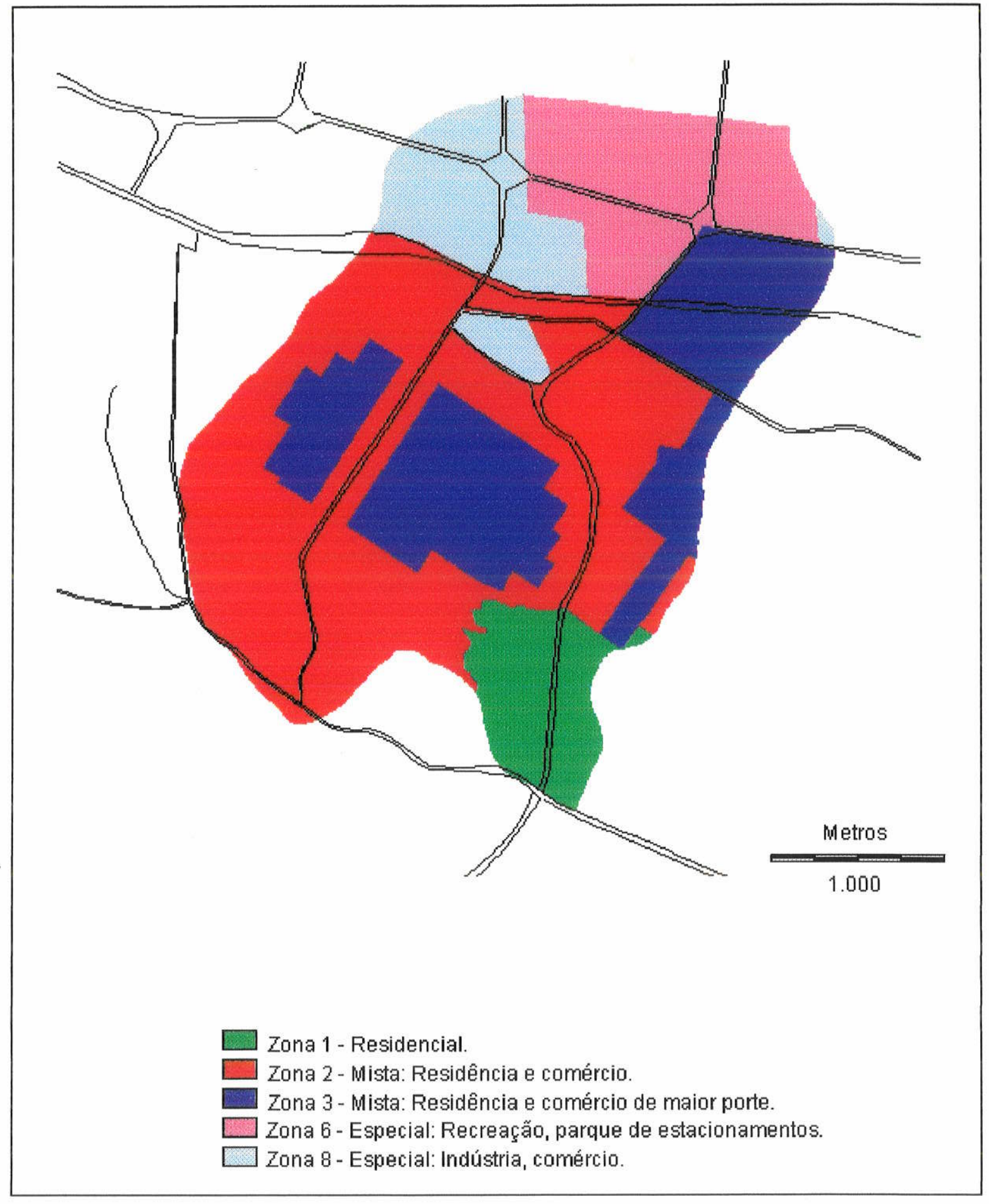

FIGURA 14 - Zoneamento Urbano. 
- $Z_{8}$ - zona especial - clubes, parques de estacionamento púbicos da Cia. Engenharia de Trafégo do municipio de São Paulo, etc., com aproveitamentos máximos variáveis, atingindo até $50 \%$.

As zonas $Z_{1}, Z_{2}$ e $Z_{3}$ perfazem um total de $7.192 .600 \mathrm{~m}^{2}$, ocupando toda a área do terreno terciário $\left(6.400 .000 \mathrm{~m}^{2}\right)$ e constitui ainda $25 \%$ da área do terreno quaternário, que possui $3.200 .000 \mathrm{~m}^{2}$. As zonas $Z_{6}$ e $Z_{8}$ situam-se dentro dos limites do terreno quaternário, com apenas $2 \%$ dentro dos limites do terreno terciário.

\subsubsection{Terreno terciário}

Para o cálculo estimativo da área impermeável nos limites do domínio do terreno terciário, foram tomadas quadras aleatoriamente, nas três (03) zonas $Z_{1}, Z_{2} \in Z_{3}$, destacandose que tais quadras são desprovidas de áreas verdes públicas. $O$ cálculo das áreas verdes públicas foi efetuado separadamente, por meio de um cadastro dos parques, jardins, praças, balões de contorno, dentre outros existentes na área estudada.

Para cada uma das amostras foi efetuado um levantamento da área ocupada pelas construções (por lote), e da área ocupada pela pavimentação domiciliar, ou cimentação. A área cimentada foi estimada em $15 \%$ do lote para a zona $Z_{1}$, e $30 \%$ para as zonas $Z_{2}$ e $Z_{3}$ (Tabela 12).

Os resultados deste levantamento e os indices de ocupação encontram-se na Tabela 12 onde se verificam taxas de impermeabilizaçăo total de $0,63,0,81$ e 0,87 para as zonas $Z_{1}$, $Z_{2}$ e $Z_{3}$, respectivamente.

\begin{tabular}{|c|c|c|c|c|c|c|c|c|}
\hline & & (1) & (2) & (3) & (4) & (5) & (6) & (7) \\
\hline ZONA & $\begin{array}{c}\mathrm{N}^{2} \\
\text { LOTES }\end{array}$ & $\begin{array}{c}\text { ÁREA DA } \\
\text { AMOSTRA } \\
\left(\mathrm{m}^{2}\right)\end{array}$ & $\begin{array}{c}\text { AREA DOS } \\
\text { LOTES } \\
\left(\mathrm{m}^{2}\right)\end{array}$ & $\begin{array}{c}\text { AREA } \\
\text { CONSTRUIDA } \\
\left(\mathrm{m}^{2}\right)\end{array}$ & $\begin{array}{c}\text { PAVIMEN- } \\
\text { TAČÁO } \\
\text { DOMICILIAR } \\
\left(\mathrm{m}^{2}\right)\end{array}$ & $\begin{array}{l}\text { PAVIMEN- } \\
\text { TACGÁO } \\
\text { VARRIA } \\
\left(\mathrm{m}^{2}\right) \\
(1)-(2)\end{array}$ & $\begin{array}{c}\text { AREA } \\
\text { IMPERME- } \\
\text { AVEL TOTAL } \\
\left(\mathrm{m}^{2}\right) \\
(3)+(4)+(5)\end{array}$ & $\begin{array}{l}\text { TAXADE } \\
\text { IMPERMEA- } \\
\text { BILIZAÇAO } \\
\text { TOTAL. } \\
(6) /(1)\end{array}$ \\
\hline$Z_{1}$ & 206 & 104.123 & 80.623 & 29.992 & 12.093 & 23.500 & 65.558 & 0,63 \\
\hline$Z_{2}$ & 415 & 128.540 & 101.140 & 47.526 & 30.342 & 27.400 & 105.268 & 0,81 \\
\hline $\mathrm{Z}_{3}$ & 802 & 242.802 & 195.802 & 105.389 & 58.740 & 47.000 & 211.129 & 0,87 \\
\hline
\end{tabular}

TABELA 12 - Parâmetros para a estimativa da taxa impermeável das áreas amostradas nas zonas $Z_{1}, Z_{2} \in Z_{3}$.

Embora pelas leis municipais de uso e ocupação do solo, a taxa de ocupação (construção) para cada uma das zonas seja limitada aos índices apresentados na Tabela 13 , verificou-se que a taxa de construção média, por lote, supera de 14 a $32 \%$ o índice permitido 
nas zonas. Este é um fato muito comum que ocorre, devido ao aumento da área construida ilegalmente nos lotes, e que é posteriormente aprovado por anistiamento. $\mathrm{Na} z o n a Z_{3}$, que é a de ocupação mais complexa e mais adensada, ocorrem as maiores discrepâncias, enquanto na zona $Z_{1}$, restritamente residencial, este problema é menos acentuado, apresentando, inclusive, um desvio padrão menor para os indices de construção.

\begin{tabular}{|c|c|c|c|c|c|}
\hline & (1) & (2) & (3) & & \\
\hline $\begin{array}{c}\text { ZONA } \\
\text { AMOSTRADA }\end{array}$ & $\begin{array}{c}\text { ¿ÁREA DAS } \\
\text { AREAS DE } \\
\text { CONSTRUÇĂO } \\
\left(\mathrm{m}^{2}\right)\end{array}$ & $\begin{array}{c}\Sigma \text { AREA DOS } \\
\text { LOTES COM } \\
\text { CONSTRUÇÃO } \\
\left(\mathrm{m}^{2}\right)\end{array}$ & $\begin{array}{c}\text { TAXA DE } \\
\text { CONSTRUÇÃO } \\
\text { EFETIVA } \\
(1) /(2)\end{array}$ & $\begin{array}{c}\text { TAXA DE } \\
\text { CONSTRUÇÃO } \\
\text { MÉDIA } \\
\text { POR LOTE } \\
\end{array}$ & $\begin{array}{l}\text { APROVEITAMENTO } \\
\text { MAXIMO PERMITIDO } \\
\text { POR LOTE } \\
\text { (LEI MUNICIPAL) }\end{array}$ \\
\hline $\mathrm{Z}_{1}$ & 29.992 & 71.365 & 0,42 & $\begin{array}{c}0,47 \\
(s d=0,19)\end{array}$ & 0,40 \\
\hline$z_{2}$ & 47.526 & 9.423 & 0,49 & $\begin{array}{c}0,58 \\
(s d=0,22)\end{array}$ & 0,50 \\
\hline \multirow[t]{2}{*}{$\mathrm{Z}_{3}$} & 105.389 & 191.861 & 0,55 & $\begin{array}{c}0,66 \\
(\mathrm{sd}=0,45)\end{array}$ & 0,50 \\
\hline & & & $\begin{array}{l}0,50 \text { (média } \\
\text { ponderada) }\end{array}$ & & \\
\hline
\end{tabular}

TABELA 13 - Parâmetros para o cálculo estimativo da taxa de construção média.

De posse dos índices de impermeabilização de cada amostra (coluna 7, Tabela 12), obteve-se o indice de impermeabilização médio para toda a área abrangida pelas três zonas $Z_{1}, Z_{2}$ e $Z_{3}$, calculando-se a média ponderada destes indices, tendo como peso as áreas das respectivas zonas. O valor encontrado foi de $\mathbf{0 , 8 1}$, conforme o cálculo apresentado abaixo:

$$
I=\frac{\left(l a z_{1} \cdot A z_{1}\right)+\left(l a z_{2} \cdot A z_{2}\right)+\left(l a z_{3} \cdot A z_{3}\right)}{A z_{1}+A z_{2}+A z_{3}}
$$

Onde:

$I=$ indice total de impermeabilização (zonas $Z_{1}+Z_{2}+Z_{3}$ )

lazi = taxa impermeável da amostra em sua respectiva zona $i$ (coluna 7 da Tabela 12)

$\mathrm{Az} i=$ área total da zona $i\left(\mathrm{em} \mathrm{m}^{2}\right)$

$$
I=\frac{(0,63 \cdot 710.100)+(0,81 \cdot 4 \cdot 171 \cdot 700)+(0,87 \cdot 2 \cdot 310.800)}{7 \cdot 192 \cdot 600}=0,81
$$

Ocorre, porém, que as quadras amostradas são desprovidas de áreas verdes públicas. O indice médio de área impermeável calculado para estas amostras, e projetado para toda a área $(0,81)$, é, portanto, superior à taxa real, pois desconsidera as áreas verdes públicas. Foi realizado, então, um levantamento da extensão destas áreas, encontrando-se uma metragem de $359.530 \mathrm{~m}^{2}$. Descontando-se este valor da área total obtém-se a taxa impermeável real de 0,77 cujo cáculo é apresentado a seguir: 
onde:

$$
I=\frac{(0,81)\left[\left(A z_{1}+A z_{2}+A z_{3}\right)-A v\right]}{A z_{1}+A z_{2}+A z_{3}}
$$

$\mathrm{I}=$ indice de impermeabilização;

$\mathrm{Az} i=$ área total da zona $i\left(\mathrm{em} \mathrm{m}^{2}\right), \mathrm{e}$

$A v=$ área verde pública $\left(\mathrm{em}^{2}\right)$

$$
I=\frac{(0.81)[(710.100+4.171 .700+2.310 .800)-340.447]}{7.192 .600}=0,77
$$

$O$ indice de impermeabilização de 0,77 obtido ratifica, portanto, o elevado índice de adensamento e impermeabilização da área. Este indice é $7 \%$ maior que a apresentada por CANHOLI (1994) para a bacia do Pacaembu adjacente no lado leste, a qual possui, na sua porção intermediária, características de ocupação bastante semelhantes às da área de estudos. A taxa encontrada por aquele autor $(0,70)$ foi estimada por meio de calibração dos parâmetros da bacia de forma a ajustar o modelo hidrológico estabelecido por meio dos hidrogramas de projeto.

Entretanto, este índice é inferior ao valor que teríamos encontrado caso tivéssemos aplicado as relações de densidade demográfica de TUCCl et al. (1989), in CAMPANA E TUCCI (1994), mostrando a inaplicabilidade deste método para a área de estudos, devido ao grande número de prédios residenciais e comerciais. Por este método encontrar-se-ia uma taxa impermeável de $64,3 \%$, que é o valor máximo permitido pela equação para uma densidade demográfica superior a $100 \mathrm{hab} / \mathrm{ha}$. Os autores citados utilizaram os dados de 11 bacias urbanas na região Metropolitana de São Paulo e ajustaram uma equação de regressão múltipla entre área impermeável e parcelas da bacia com diferentes tipos de densidade demográfica cuja equação foi obtida com coeficiente de determinação de 0,96 de desvio padrão de $3,6 \%$.

\subsubsection{Terreno quaternário}

O índice de impermeabilização no terreno quaternário foi estimado de forma análoga ao terreno terciário, adotando-se o indice de ocupação máximo permitido pela legislação vigente. Encontrou-se um índice de impermeabilização total de 0,76 e 0,60 para as zonas Z6 e Z8, respectivamente, sem se considerar as área livres (lotes vagos, campos de futebol, praças, parques e jardins). Realizou-se um levantamento destas áreas livres por fotografias aéreas para correção da taxa impermeável, encontrando-se uma média de $60 \%$, pela ponderação das duas zonas. 
Apresenta-se no Quadro 1 a sintese da distribuição das áreas impermeabilizadas e não impermeabilizadas, de acordo com o tipo de uso em cada uma das zonas de ocupação.

$O$ indice de impermeabilização das bacias, é, portanto, de 0.73 , que representa a média ponderada dos índices obtidos em cada um dos terrenos.

\subsection{ESTUDO DA RECARGA DIRETA}

O volume infiltrado foi medido pelo método direto, ou seja, por meio da leitura direta e sistemática da oscilação sazonal do nivel d'água no periodo de 14 meses (set/94 a out/95), em 12 poços de monitoramento, sendo que dos treze poços perfurados, um poço $\left(n^{\circ} 11\right)$ foi abondonado por apresentar problemas de colmatação da seção filtrante por material argiloso.

O periodo de medição abrangeu as duas estações climáticas bem definidas, sendo uma úmida - de out/94 a mar/95 - e outra seca - de abr/95 a set/95.

Os intervalos de medições mensais foi inicialmente proposto, verificando-se, porém, já na segunda medição, realizada em 25/out/94, que os níveis d'água nos poços respondiam diferenciadamente às primeiras precipitaçōes ocorridas desde a segunda quinzena daquele mês: em alguns poços o nível d'água se elevou, enquanto em outros não, em relação à leitura anterior, feita em 25/set/94). O intervalo de medição foi, então, reduzido para 15 dias durante a estação úmida (dez/94 a mar/95, estendendo-se até abril/95), para um melhor acompanhamento destas oscilações.

Ao final do período de doze meses, realizou-se um monitoramento no aqüifero terciário a cada quatro dias, por 44 dias, a partir da chegada das chuvas do ciclo seguinte (set/95), sob condições de umidade do solo bastante baixas, isto é, logo após o periodo de estiagem.

Os poços de monitoramento foram individualizados, segundo o contexto geológico, em dois grupos: quatro poços, localizados nos sedimentos quaternários da várzea do Rio Tietê (Poços 1, 2, 4 e 7), com profundidades entre $3,4-4,6 \mathrm{~m}$; e nove poços localizados nos sedimentos terciários, sendo, quatro mais rasos, com profundidades entre $3,8-5,8 \mathrm{~m}$. (Poços $6,8,9$ e12) e cinco mais profundos, entre $8,3-12,0 \mathrm{~m}$ (Poços 3, 5, 10,11 e 13), atingindo de 1,0 a $2,7 \mathrm{~m}$ abaixo do nivel freático.

A recarga anual foi calculada pela soma dos incrementos mensais de recarga, ou seja, de todos os meses em que houve um acréscimo na espessura saturada em relação ao mês antecedente, de acordo com a seguinte expressão:

$$
R_{D}=A \cdot \Delta h \cdot n e f
$$


onde:

$\mathbf{R}_{\mathrm{D}}=$ Recarga mensal direta medida, em $\mathrm{m}^{3}$;

$\mathbf{A}=$ Área do aqüifero livre da impermeabilização, $\mathrm{em}^{2}$;

$\Delta \mathbf{h}=$ Elevação do nivel freático em relação ao mês antecedente, em $\mathrm{m}, \mathrm{e}$

nef $=$ Porosidade efetiva, adimensional.

\begin{tabular}{|c|c|c|c|c|c|}
\hline $\begin{array}{l}\text { ZONAS DE } \\
\text { OCUPAÇÃO }\end{array}$ & $\begin{array}{c}\text { ÁREA } \\
\text { TOTAL } \\
\left(\mathbf{m}^{2}\right)\end{array}$ & & $\begin{array}{l}\text { ÍNDICE DE OCUPAÇĀO } \\
\text { POR TIPO DE USO }\end{array}$ & $\begin{array}{c}\text { AREA } \\
\text { CORRES- } \\
\text { PONDENTE } \\
\left(\mathrm{m}^{2}\right)\end{array}$ & $\begin{array}{c}\text { *ÁAEA DOS } \\
\text { LOTES } \\
\left(\mathrm{m}^{2}\right) \\
(0,80 \times \text { área } \\
\text { total menos } \\
\text { área verde } \\
\text { pública) }\end{array}$ \\
\hline \multirow[b]{2}{*}{$\begin{array}{l}\text { Z1 - Z2 - Z3 - } \\
\text { (Residencial- } \\
\text { comércial- } \\
\text { serviços) }\end{array}$} & \multirow{2}{*}{7.192 .600} & $\begin{array}{l}\text { área } \\
\text { perméavel } \\
(23 \%)\end{array}$ & $\begin{array}{l}5,0 \% \text { - áreas verdes } \\
\text { públicas } \\
\text { (parques, jardins, balöes de } \\
\text { contorno) } \\
4,5 \% \text { - lotes vagos } \\
\begin{array}{l}* 13,5 \% \text { - Jardins } \\
\text { domiciliares* }\end{array}\end{array}$ & $\begin{array}{l}* * 359.630 \\
323.667 \\
971.001\end{array}$ & \multirow[b]{2}{*}{5.394 .450} \\
\hline & & $\mid \begin{array}{l}\text { área } \\
\text { impermeável } \\
(77 \%)\end{array}$ & $\begin{array}{l}57 \% \text { - área construida }+ \\
\text { pavimentação domiciliar } \\
20 \% \text { - pavimentação viária }\end{array}$ & $\begin{array}{l}4.099 .782 \\
1.438 .520\end{array}$ & \\
\hline \multirow[b]{2}{*}{$\begin{array}{c}\text { Z6 - Z8 } \\
\text { (industrial- } \\
\text { recreação) }\end{array}$} & \multirow{2}{*}{2.407 .400} & $\begin{array}{l}\text { área } \\
\text { perméavel } \\
(40 \%)\end{array}$ & $\begin{array}{l}3 \% \text { - áreas verdes públicas } \\
37 \% \text { - lotes vagos, campos } \\
\text { de futebol, etc. }\end{array}$ & 72.222 & \multirow{2}{*}{1.853 .698} \\
\hline & & $\begin{array}{l}\text { área } \\
\text { impermeável } \\
(60 \%)\end{array}$ & $\begin{array}{l}20 \% \text { - pavimentaçăo viária } \\
40 \% \text {-área construida + } \\
\text { pavimentação domiciliar } \\
\text { (quadras, pátios de } \\
\text { estacionamento, etc) }\end{array}$ & 481.480 & \\
\hline TOTAL & 9.600 .000 & & & 9.600 .000 & 7.248 .148 \\
\hline
\end{tabular}

* concentrados, principalmente na zona Z1 e bairros isolados nas demais zonas de ocupação.

** $20 \%$ da área são cobertos pela pavimentação viária.

**** valor medido

QUADRO 1 - Distribuição dos índices de ocupação por tipo de uso 


\subsubsection{Aqǘfero terciário}

Dentre os parâmetros da equação anteriormente citada, a porosidade efetiva $\left(n_{\mathrm{ef}}\right)$ foi o mais difícil de se estimar, em razão da grande variabilidade espacial (lateral e vertical) dos constituintes granulométricos. Ela é afetada pela distribuição granulométrica, tamanho dos grãos e umidade do solo (CUSTÓDIO E LHAMAS, 1976), podendo ser estimada por meio de ensaio de aqüifero ou em laboratório.

Valores para todo o pacote de sedimentos terciários, têm sido citados na literatura normalmente com base no seu caráter faciológico, citando-se: SABESP/CEPAS (1994): 0,7 e DAEE (1975): 0,02 a 0,1 . Pode-se citar ainda valores entre 0,2 e 0,12, encontrados por IRITANI (1993), por meio de teste hidrodinâmico em um poço locado no contexto arenoso da $\mathrm{Fm}$. Itaquaquecetuba, sendo que os valores mais elevados referem-se ao nivel freático.

Valores médios são também apontados na literatura, para diversos tipos de solos, citando-se 0,07 para argila arenosa e 0,26 par areias médias (CUSTÓDIO E LHAMAS,1976), cujos solos são correlacionáveis aos da área. A média destes valores $(0,16)$ se aproxima do valor encontrado na amostra escolhida.

Neste estudo a porosidade efetiva em questão é a correspondente à da seção do perfil do solo abrangida pela flutuação sazonal da superfície freática. Tal trecho correspondeu, às camadas mais arenosas (Figura 9 do Anexo 2), constituidas freqüentemente de areias e areias argilosas.

Para avaliação da porosidade efetiva no terreno terciário, foram retiradas amostras indeformadas, no domínio da $\mathrm{Fm}$. Resende, à profundidade de $0,5 \mathrm{~m}$ (amostra 08E), junto ao poço de monitoramento $n^{\circ} 8$. Tais amostras foram submetidas a ensaios da curva de retenção de água, a partir da qual obteve-se o volume de macroporos (ou porosidade efetiva), responsável pela percolação, conforme explicitado no item 4.3.3. A constituição granulométrica do solo local é: $43 \%$ de areia, $40 \%$ de argila, $8 \%$ de grânulos e $9 \%$ de silte, com indice de grossos/finos de 1,02 (Tabela 1).

O resultado obtido foi de 0,13 (Figura 15), devendo-se no entanto, frisar que, apesar de uma única amostra ter sido retirada, o indice de grossos/finos é bastante respresentativo para o tipo litológico onde ocorre a flutuação da superficie freática. 


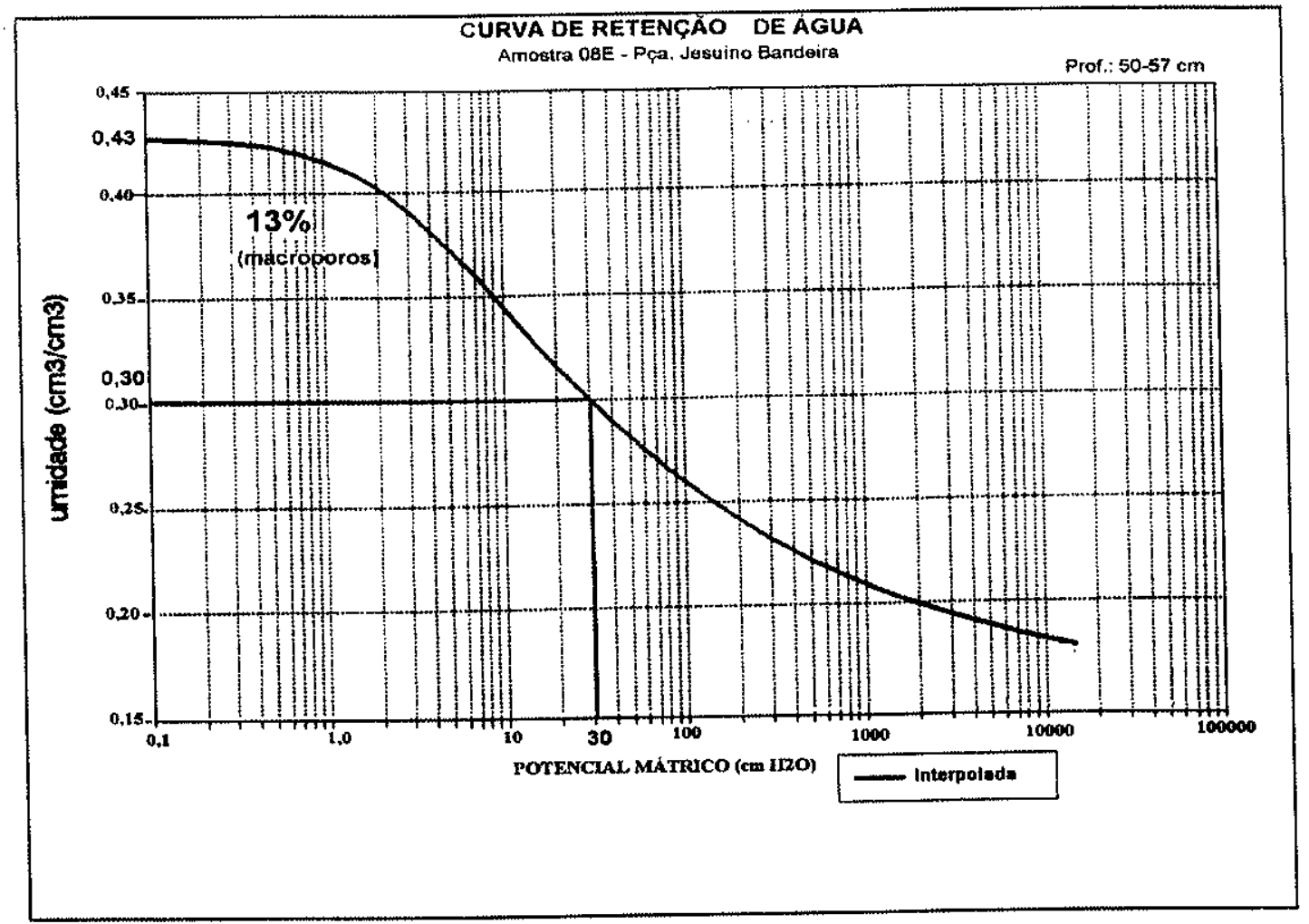

FIGURA 15 - Curva de Retenção e porosidade efetiva

Cabe ressaltar que a adensada ocupação restringiu os pontos de amostragem às praças públicas e aos terrenos vagos particulares, em detrimento de um maior número de pontos, dadas as dificuldades impostas pelo método de amostragem, que consiste na abertura de trincheiras de dimensões consideráveis.

Os valores da elevação da superficie freática $(\Delta h)$ correspondeu à média ponderada das elevações medidas nos poços mais rasos e nos poços mais profundos em relação às respectivas áreas de ocorrência destas profundidades. A área de ocorréncia dos niveis mais profundos, aqui considerados acima de $4 \mathrm{~m}$, é de aproximadamente $4,5 \mathrm{~km}^{2}$ e as dos níveis mais rasos, menores que $4 \mathrm{~m}$, é de $1,9 \mathrm{~km}^{2}$, conforme mostrado no mapa de isoprofundidade (Figura 10). A média total de $\Delta \mathrm{h}$ foi de $1,74 \mathrm{~m} / \mathrm{ano}$.

No cálculo da recarga foi considerada apenas a área do aqüifero disponível para a infiltração direta, isto é, aquela que em superficie, se encontra livre da impermeabilização. Foi estimado para toda a área do aqüifero terciário, onde se encontra a maior ocupação residencial-comercial-serviços, uma área impermeável de $77 \%$, ou seja, apenas $23 \%(1,47$ $\mathrm{km}^{2}$ ) constituem a superficie disponivel para a infiltração, conforme visto no item 6.1.5. 
A Tabela 14 resume os valores dos parâmetros para o cálculo da recarga e o seu vaior obtido mensalmente. A recarga de $0,33 \mathrm{Mm}^{3}$ representa $3 \%$ do total precipitado no dominio terciário durante o ciclo considerado, que foi de $11,6 \mathrm{Mm}^{3}$, sendo que cerca de $83 \%$ desta recarga $\left(0,28 \mathrm{Mm}^{3}\right)$ ocorreu na estação úmida, entre os meses de outubro a março, e os $17 \%$ restantes $\left(0,05 \mathrm{Mm}^{3}\right)$, ocorreu durante a estação seca, de abril a setembro.

$\mathrm{Na}$ estação seca, não se verificou recarga nos meses de maio, agosto e setembro, porém a recarga ocorrida apenas no mês de julho/95 $\left(0,03 \mathrm{Mm}^{3}\right)$, correspondeu a $9 \%$ da total anual.

\begin{tabular}{|c|c|c|c|c|}
\hline MÊS & $\begin{array}{c}A \\
\left(\mathrm{~km}^{2}\right)\end{array}$ & $\begin{array}{l}\Delta \mathbf{h} \\
(\mathrm{m})\end{array}$ & nef & $\begin{array}{c}R \\
\left(\mathrm{Mm}^{3}\right) \\
\end{array}$ \\
\hline Outubro / 94 & 1,47 & 0,04 & 0,13 & 0,00764 \\
\hline Novembro / 94 & 1,47 & 0,26 & 0,13 & 0,04968 \\
\hline Dezembro / 94 & 1,47 & 0,32 & 0,13 & 0,06115 \\
\hline Janeiro / 95 & 1,47 & 0,28 & 0,13 & 0,05350 \\
\hline Fevereiro / 95 & 1,47 & 0,52 & 0,13 & 0,09937 \\
\hline Março / 95 & 1,47 & 0,03 & 0,13 & 0,00573 \\
\hline Abril / 95 & 1,47 & 0,04 & 0,13 & 0,00764 \\
\hline Maio / 95 & 1,47 & 0 & 0,13 & 0 \\
\hline Junho / 95 & 1,47 & 0,08 & 0,13 & 0,01528 \\
\hline Julho / 95 & 1,47 & 0,17 & 0,13 & 0,03248 \\
\hline Agosto / 95 & 1,47 & 0 & 0,13 & 0 \\
\hline Setembro / 95 & 1,47 & 0 & 0,13 & 0 \\
\hline Total & & 1,74 & & 0,33 \\
\hline
\end{tabular}

\section{TABELA 14 - Recargas diretas mensais no aqüifero terciário}

\subsubsection{Aqüífero quaternário}

A estimativa da recarga correspondente ao terreno quaternário foi calculada de forma análoga à apresentada para o terreno terciário. A área do aqüifero, que em superfície se encontra livre da impermeabilização, é de $1,28 \mathrm{~km}^{2}$ (40\% do terreno quaternário). As profundidades do nível d'água medidos neste terreno são bastante homogêneas e não ultrapassam $3,0 \mathrm{~m}$.

Dada a ausência de indicadores da porosidade efetiva no terreno quaternário, foi admitido o valor de 0,13 , obtido para o terreno terciário, uma vez que a oscilação sazonal do nível freático ocorre também entre as camadas mais arenosas e relativamente mais imaturos.

A recarga direta encontrada para todo o ciclo foi de $0,31 \mathrm{Mm}^{3}$ (Tabela 15), a qual representa aproximadamente $5 \%$ do volume precipitado no terreno quaternário, que foi de 5,8 
$\mathrm{Mm}^{3}$. Cerca de $80 \%$ desta recarga $\left(0,25 \mathrm{Mm}^{3}\right)$ incidiram na estação úmida, e $20 \%\left(0,05 \mathrm{Mm}^{3}\right)$ na estação seca.

\begin{tabular}{|c|c|c|c|c|}
\hline MÊS & $\underset{\left(\mathrm{km}^{2}\right)}{A}$ & $\begin{array}{l}\Delta \mathrm{h} \\
(\mathrm{m})\end{array}$ & nef & $\begin{array}{c}\mathbf{R} \\
\left(\mathrm{Mm}^{3}\right) \\
\end{array}$ \\
\hline Outubro / 94 & 1,28 & 0,07 & 0,13 & 0,011648 \\
\hline Novembro / 94 & 1,28 & 0,17 & 0,13 & 0,028288 \\
\hline Dezembro / 94 & 1,28 & 0,40 & 0,13 & 0,06656 \\
\hline Janeiro / 95 & 1,28 & 0,25 & 0.13 & 0,04160 \\
\hline Fevereiro / 95 & 1,28 & 0,60 & 0,13 & 0,09984 \\
\hline Março / 95 & 1,28 & 0,07 & 0,13 & 0,01164 \\
\hline Abril / 95 & 1,28 & 0,12 & 0,13 & 0,01996 \\
\hline Maio / 95 & 1,28 & 0 & 0,13 & 0 \\
\hline Junho / 95 & 1,28 & 0,09 & 0,13 & 0,014976 \\
\hline Julho / 95 & 1,28 & 0,11 & 0,13 & 0,018304 \\
\hline Agosto / 95 & 1,28 & 0 & 0,13 & 0 \\
\hline Setembro / 95 & 1,28 & 0 & 0,13 & 0 \\
\hline Total & & 1,88 & & 0,31 \\
\hline
\end{tabular}

TABELA 15 - Recargas diretas mensais no terreno quaternário

Os meses de maio, agosto e setembro foram desprovidos de recarga, assim como ocorreu no aqüifero terciário.

A recarga direta total nos dois aqüiferos foi de $67,2 \mathrm{~mm} / \mathrm{ano}$ ou $0,64 \mathrm{Mm}^{3} /$ ano (Tabela 16), que representa $4 \%$ da precipitação total ( $1818 \mathrm{~mm} / \mathrm{ano}$ ).

A precipitação ocorrida apenas nas áreas não impermeabilizadas foi de $27 \%$ (índice da área não impermeabilizada) da precipitação total (1818 mm/ano), ou seja $491 \mathrm{~mm} / \mathrm{ano}$. Dessa forma a recarga direta obtida $(67,2 \mathrm{~mm} / \mathrm{ano})$ representou cerca de $13 \%$ da quantidade precipitada diretamente nestas áreas.

As taxas de recarga especifica para os dois terrenos foram:

- Aqüifero terciário: $0,05 \mathrm{Mm}^{3} / \mathrm{km}^{2} /$ ano $\left(5,4 \mathrm{~mm} / \mathrm{km}^{2} / \mathrm{ano}\right)$

- Aqüifero quaternário: $0,10 \mathrm{Mm}^{3} / \mathrm{km}^{2} / \mathrm{ano}\left(10,2 \mathrm{~mm} / \mathrm{km}^{2} / \mathrm{ano}\right)$

- módia: $0,06 \mathrm{Mm}^{3} / \mathrm{km}^{2} / \mathrm{ano}\left(7 \mathrm{~mm} / \mathrm{km}^{2} / \mathrm{ano}\right.$ )

A considerável diferença da taxa de recarga especifica a favor do terreno quaternário, da ordem da ordem de $50 \%$, é explicada pelas condições mais favoráveis à infiltraçăo e armazenamento, tanto do ponto de vista de ocupação $(40 \%$ de área livre da impermeabilização) como pela menor declividade do terreno e do gradiente hidráulico.

Comparando-se a taxa de recarga especifica média encontrada de $0,06 \mathrm{Mm}^{3} / \mathrm{km}^{2} / \mathrm{ano}$, com a estimada por IRITANI (1993) para a Cidade Universitária, $0,24 \mathrm{Mm}^{3} / \mathrm{km}^{2} / a n o$, observa- 
se que esta é quatro vezes maior, denotando a influência da impermeabilização sobre a infiltração direta.

A Figura 16 ilustra os volumes anuais precipitados e infiltrados no aqüífero freático da área, para os dois domínios aqüíferos.

\begin{tabular}{|c|c|c|c|c|c|c|c|c|}
\hline \multirow[t]{2}{*}{ MESES } & \multicolumn{2}{|c|}{ PRECIPITAÇÃO } & \multicolumn{2}{|c|}{ RECARGA TOTAL } & \multicolumn{2}{|c|}{$\begin{array}{l}\text { RECARGA DIRETA NO } \\
\text { AQUIFEERO } \\
\text { TERCIÁRIO }\end{array}$} & \multicolumn{2}{|c|}{$\begin{array}{l}\text { RECARGA DIRETA NO } \\
\text { NO AQUÍFERO } \\
\text { QUATERNÁRIO }\end{array}$} \\
\hline & $(\mathrm{mm})$ & $\left(\mathrm{Mm}^{3}\right)$ & $(\mathrm{mm})$ & $\left(\mathrm{Mm}^{3}\right)$ & $(\mathrm{mm})$ & $\left(\mathrm{Mm}^{3}\right)$ & $(\mathrm{mm})$ & $\left(\mathrm{Mm}^{3}\right)$ \\
\hline Out/94 & 93 & 0,8928 & 2,0 & 0,01928 & 0,79583 & 0,00764 & 1,21333 & 0,01165 \\
\hline Nov/94 & 124 & 1,1904 & 8,1 & 0,07796 & 5,17500 & 0,04968 & 2,94667 & 0,02829 \\
\hline Dez/94 & 284 & 2,7264 & 13,3 & 0,12771 & 6,36979 & 0,06115 & 6,93333 & 0,06656 \\
\hline Jan/95 & 376 & 3,6096 & 9,9 & 0,09510 & 5,57292 & 0,05350 & 4,33333 & 0,04160 \\
\hline Fev/95 & 395 & 3,7920 & 20,8 & 0,19921 & 10,35104 & 0,09937 & 10,40000 & 0,09984 \\
\hline Mar/95 & 251 & 2,4096 & 1,8 & 0,01737 & 0,59688 & 0,00573 & 1,21250 & 0,01164 \\
\hline Abr/95 & 49 & 0,4704 & 2,9 & 0,02760 & 0,79583 & 0,00764 & 2,07917 & 0,01996 \\
\hline Mai/95 & 61 & 0,5856 & 0 & 0,00000 & 0,00000 & 0,00000 & 0,00000 & 0,00000 \\
\hline Jun/95 & 41 & 0,3936 & 3,1 & 0,03025 & 1,59167 & 0,01528 & 1,56000 & 0,01498 \\
\hline Jul/95 & 67 & 0,6432 & 5,3 & 0,05078 & 3,38333 & 0,03248 & 1,90667 & 0,01830 \\
\hline Ago/95 & 22 & 0,2112 & 0 & 0,00000 & 0,00000 & 0,00000 & 0,00000 & 0,00000 \\
\hline Set/95 & 55 & 0,528 & 0 & 0,00000 & 0,00000 & 0,00000 & 0,00000 & 0,00000 \\
\hline TOTAL & 1818 & 17,4528 & 67,2 & 0,64 & 34,6 & 0,33 & 32,6 & 0,31 \\
\hline
\end{tabular}

TABELA 16 - Distribuição das recargas nos aquíferos terciário e quaternário.

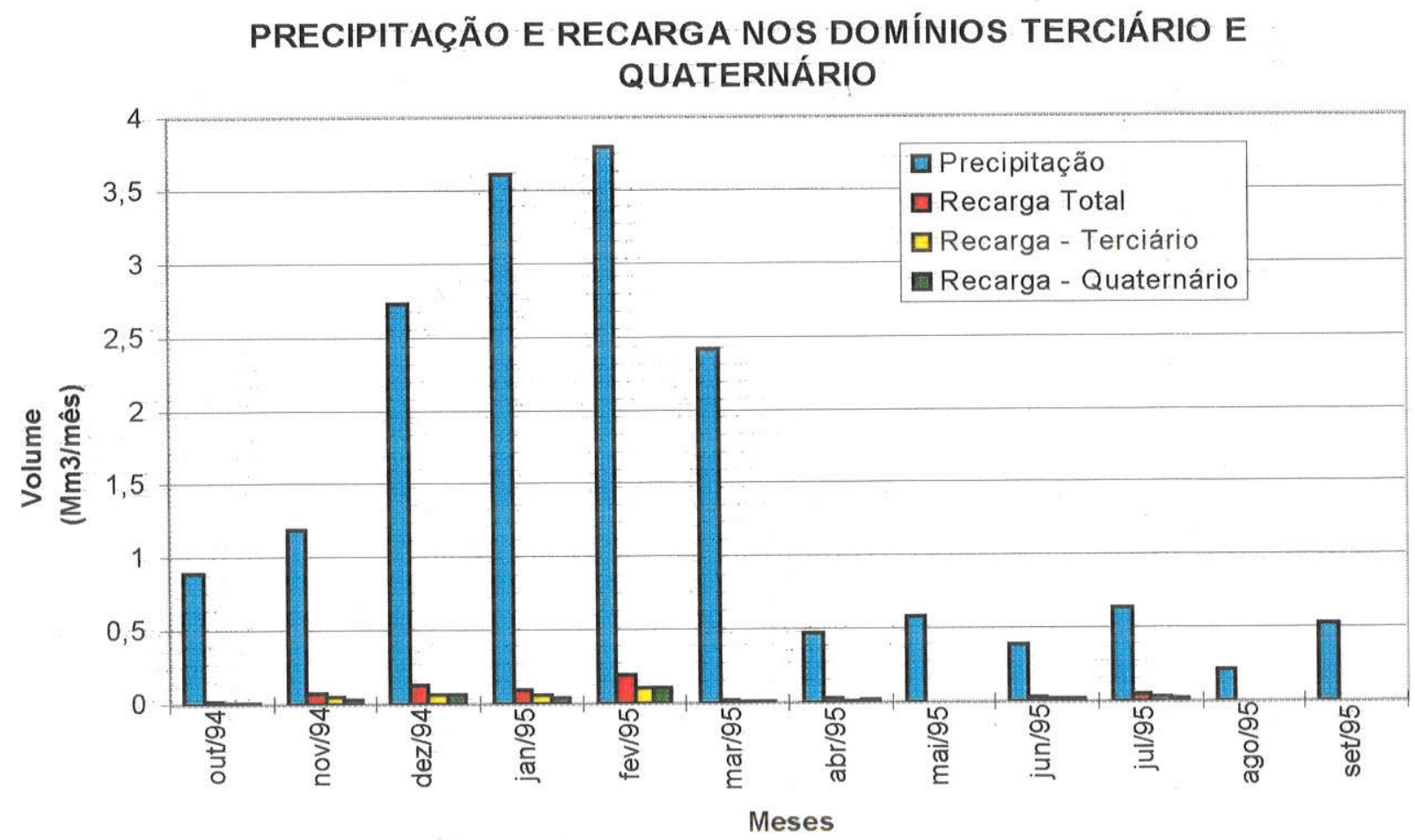

FIGURA 16 - Precipitação e recarga nos domínios Terciário e Quaternário 


\subsection{ESTUDO DA RECARGA INDIRETA}

Os vazamentos da rede de distribuição da SABESP, constituem a principal fonte de recarga dos aqüiferos na área. De acordo com informações da Companhia, cerca de $80 \%$ das perdas físicas ocorrem nas ligações domésticas, sendo que tal predominância é também citada pela maioria dos trabalhos internacionais.

A profundidade de ocorrencia dos vazamentos, em torno de $2 \mathrm{~m}$, leva a pressupor que a maior parte destes volumes atinge o aqüifero freático. A outra parte pode seguir os seguintes caminhos: escoar superficialmente, devido à pressão na rede de distribuição, ou infiltrar para dentro das tubulações da rede de esgotos ou da rede pluvial.

Apesar de cada vazamento ocorrer aleatoriamente no tempo e no espaço, admite-se que o conjunto dos vazamentos, seja de natureza contínua, dada a sua ocorrência antes, durante e após o periodo de monitoramento.

Os índices mensais dos vazamentos, por setor, da rede de distribuição de água durante o ciclo de 12 meses foram fornecidos pela SABESP.

O atual sistema de medição dos índices de perdas, foi pioneiramente implantado no Setor Água Branca, em fevereiro de 1992, o qual serviu de setor piloto, para as medições nos demais setores, iniciadas a partir de março de 1993. O índice de perdas total fornecido, é calculado pela relação entre o volume entregue (macromedição) e o volume medido nos hidrômetros de consumo (micromedição). No Quadro 2 é apresentada a distribuição geral das perdas segundo suas várias origens, estimados pela SABESP.

\begin{tabular}{|c|c|c|c|c|c|c|}
\hline TIPO DE PERDA & $\begin{array}{c}\text { VALOR } \\
\text { MINIMO } \\
(\mathrm{m} / \mathrm{s})\end{array}$ & $\begin{array}{c}\text { VALOR } \\
\text { MÁXIMO } \\
\text { (m/3/s) }\end{array}$ & $\begin{array}{c}\text { HIPOTESE DE } \\
\text { TRABALHO } \\
\text { (m3/s) }\end{array}$ & $\begin{array}{c}\text { PORCENTAGEM } \\
\text { DO VOLUME } \\
\text { ADUZIDO } \\
(\%)\end{array}$ & $\begin{array}{l}\text { PERDAS } \\
\text { FisICAS } \\
(\%)\end{array}$ & $\begin{array}{c}\text { PERDAS } \\
\text { NÁO } \\
\text { FISICAS } \\
(\%)\end{array}$ \\
\hline Vazamentos & 8,9 & 10,5 & 3,9 & 47,6 & 47,6 & - \\
\hline Macromedição & 0,5 & 2,0 & 1,0 & 5,3 & - & 5,3 \\
\hline Micromedição & 3,4 & 4,2 & 3,8 & 20,3 & - & 20,3 \\
\hline Habitaçס̋es sub-normais & 0,9 & 3,7 & 1,8 & 9,6 & 3,4 & 6,3 \\
\hline Gestäo comercial & 1,8 & 4,5 & 3,2 & 17,1 & - & 17,1 \\
\hline TOTAL & & & 18,7 & 100,0 & 51,0 & 49,0 \\
\hline
\end{tabular}

QUADRO 2 - Perdas de água, segundo as origens para a RMSP (SABESP)

Os valores da hipótese de trabalho estão relacionados aos indicadores de perdas de novembro/1992, correspondente a um indice de perda global de cerca de $40 \%$ em relação aos sistemas operados pela Sabesp. 
A área de estudos é atendida por cinco setores de abastecimento de água, que se encontram-se aí apenas parcialmente inseridos. Os setores em questão são: Água Branca, Araçá, Vila Romana, Casa Verde (centro) e Freguesia do O (Figura 17).

Os volumes dos vazamentos foram estimados, admitindo-se uma razão direta entre o volume total perdido em cada setor e o volume perdido nos respectivos setores dentro da área de estudos, proporcionalmente à extensão das áreas.

Apesar das perdas ocorrerem de forma isolada (ou pontual), efetuou-se esta relação após verificar-se uma continuidade na densidade das redes de distribuição para além dos limites da área, em cada setor.

$\mathrm{Na}$ Tabela 17 estão apresentados os volumes de perda física estimados na área para cada setor. Cabe dizer que, para o cálculo de perda total, o índice adotado foi de 0,476 e não 0,51 como apresentado no Quadro 2, pois não se verifica a presença de habitações subnormais dentro dos limites da área estudada. Foi primeiramente calculado o volume de perda física para cada setor, que representa $47,6 \%$ do total perdido, e posteriormente o volume de vazamentos na área de estudos, por meio de proporção simples e direta, conforme mencionado no parágrafo anterior (Tabela 17). $O$ volume correspondente às perdas por vazamentos encontrado foi de $5,11 \mathrm{Mm}^{3} / a n o(532 \mathrm{~mm} / \mathrm{ano})$, que representa cerca de 8 vezes a recarga direta total $\left(0,64 \mathrm{Mm}^{3}\right)$. 


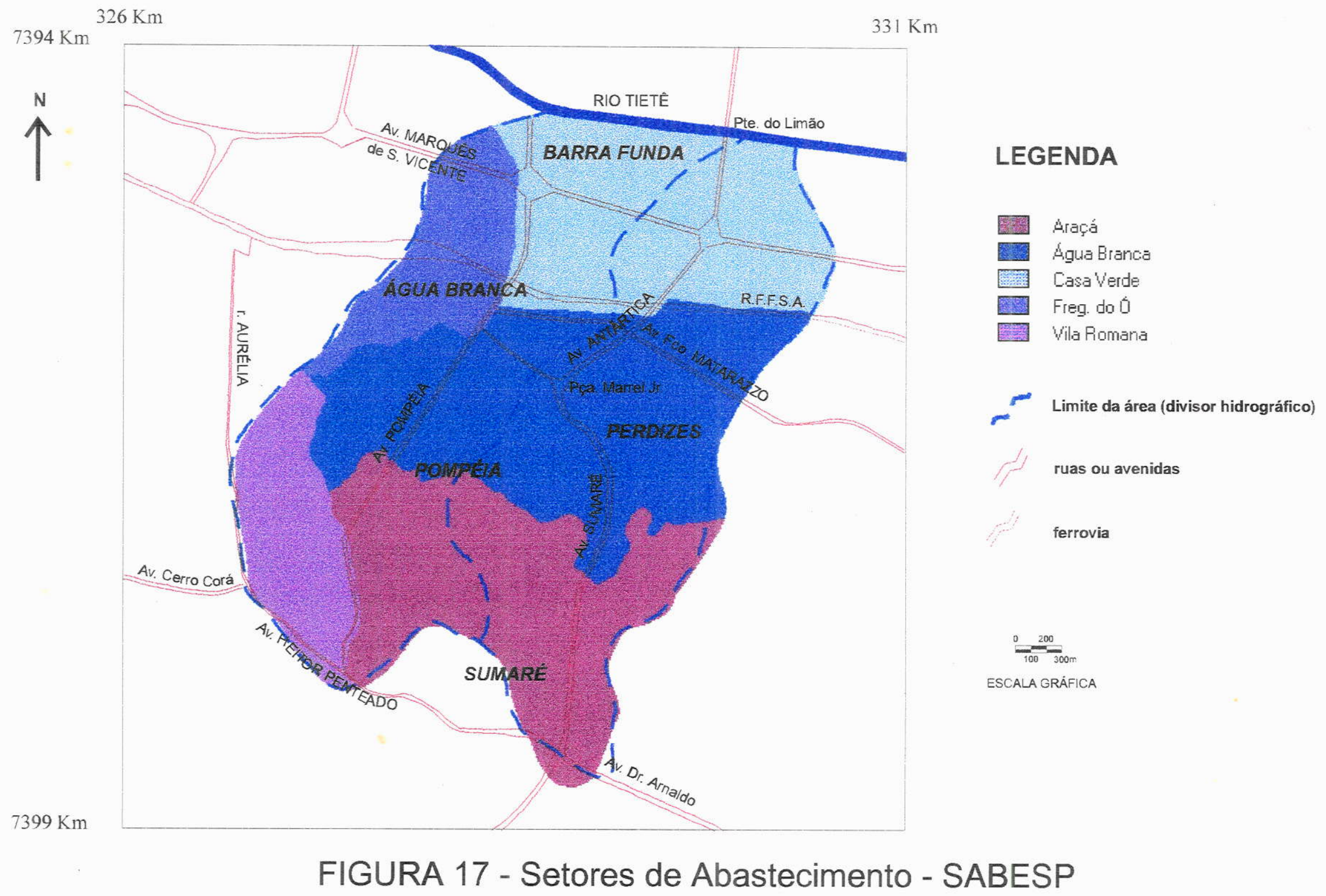




\begin{tabular}{|c|c|c|c|c|c|c|c|c|}
\hline $\begin{array}{c}\text { Setor de } \\
\text { abasteci-mento }\end{array}$ & $\begin{array}{l}\text { * Área } \\
\text { do } \\
\text { setor } \\
\left(\mathrm{km}^{2}\right)\end{array}$ & $\begin{array}{l}\text { Extensão } \\
\text { na área } \\
\text { de } \\
\text { estudos } \\
\left(\mathbf{k m}^{2}\right)\end{array}$ & $\begin{array}{c}\text { *Volume } \\
\text { entregue } \\
\text { no setor } \\
\left(\mathrm{Mm}^{3}\right)\end{array}$ & $\begin{array}{c}\text { *Perda } \\
\text { total) } \\
\left(\mathrm{Mm}^{3}\right)\end{array}$ & $\begin{array}{l}\text { Índice } \\
\text { médio- } \\
\text { perda } \\
\text { total }\end{array}$ & $\begin{array}{c}\text { ^Índice } \\
\text { perda } \\
\text { física } \\
\text { (Sabesp) }\end{array}$ & $\begin{array}{c}\text { Perda } \\
\text { física- } \\
\text { setor } \\
\left(\mathrm{m}^{3}\right)\end{array}$ & $\begin{array}{c}\text { Perda } \\
\text { fisica } \\
\text { na área } \\
\left(\mathrm{Mm}^{3}\right)\end{array}$ \\
\hline $\begin{array}{c}\text { Agua Branca } \\
\text { Araçá } \\
\text { Vila Romana } \\
\text { Casa Verde } \\
\text { Freguesia do O } \\
\end{array}$ & $\begin{array}{c}3,57 \\
7,52 \\
11,41 \\
11,39 \\
16,12 \\
\end{array}$ & $\begin{array}{l}3,12 \\
2,42 \\
0,96 \\
2,23 \\
0,90 \\
\end{array}$ & $\begin{array}{c}22, .318 \\
21, .845 \\
17,512 \\
2,122 \\
3,673 \\
\end{array}$ & $\begin{array}{c}7,550 \\
10,298 \\
6,751 \\
0,943 \\
1.775 \\
\end{array}$ & $\begin{array}{l}0,33 \\
0,47 \\
0,37 \\
0,44 \\
0,48 \\
\end{array}$ & $\begin{array}{l}0,476 \\
0,476 \\
0,476 \\
0,476 \\
0,476 \\
\end{array}$ & $\begin{array}{c}3,59 \\
4,90 \\
3,23 \\
0,44 \\
0,845 \\
\end{array}$ & $\begin{array}{l}3,14 \\
1,56 \\
0,27 \\
0,09 \\
0,05 \\
\end{array}$ \\
\hline TOTAL & & & 67,47 & & & & 13,05 & 5,11 \\
\hline
\end{tabular}

* fornecidos pela SABESP

TABELA 17 - Parâmetros do cálculo das perdas físicas na área de estudos no período de out/1994 a set/1995.

A quase totalidade desta recarga indireta (97\%) ocorre nos terrenos terciários, onde se encerram os setores de abastecimento Água Branca, Araçá e Vila Romana, que possuem os maiores volumes de perda física na área.

Evidentemente que outras fontes de recarga indireta ocorrem na área, principalmente as perdas nas redes de esgotos e irrigações, entretanto, a estimativa destas infiltrações é de dificil controle.

\subsection{CÁLCULO DA RECARGA TOTAL}

A recarga total corresponde à somatória das contribuições das duas fontes de recarga, a direta da precipitação $\left(0,64 \mathrm{Mm}^{3} / a n o\right)$ e a indireta $\left(5,11 \mathrm{Mm}^{3} / a n o\right)$, resultando num volume total de $5,75 \mathrm{Mm}^{3} / a n o$ (600 mm/ano) para toda bacia, dos quais, $89 \%$ são provenientes dos vazamentos da rede de abastecimento.

\subsection{AVALIAÇÃO DOS EFEITOS DA IMPERMEABILIZAÇÃO SOBRE A RECARGA}

A análise quantitativa dos efeitos da impermeabilização sobre a recarga foi fundamentada no balanço das entradas e saídas potenciais dos volumes de água no sistema hidrológico considerado, comparando-as com os valores atuais estimados, tendo-se em consideração as características de ocupação e impermeabilização da bacia. Para tanto foi efetuado um estudo do balanço hídrico climático em conjunto com os resultados de recarga obtidos 


\subsubsection{O Balanço hídrico climático}

\subsubsection{Situação de pré-ocupação da bacia}

O balanço hídrico foi realizado visando a obter os parâmetros de evaporação e escoamento, nas situações de pré e pós-ocupação da área.

O balanço foi realizado para o período de 1 ano, com base nas tabelas adaptadas por CAMARGO (1960), originalmente elaborados por THORNTHWAITE (1955). Esse método se baseia no confronto dos dois elementos climáticos: a precipitação pluviométrica (acréscimo de umidade) e a evapotranspiração potencial, que representa a perda potencial de umidade, fornecendo dados mensais do armazenamento de água no solo, o deficit e o excedente hidrico ou escoamento.

Salienta-se que o termo escoamento empregado neste item, na mesma linguagem do programa utilizado, representando a somatória da parcela da água que infiltra mais a que escoa superficialmente.

A equação original de THORNTHWAITE (1955), in TUCCl (1993), é baseada em dados de precipitação e temperatura de inúmeras bacias hidrográficas localizadas nas regiőes central e leste dos Estados Unidos, onde predomina um clima temperado com invernos úmidos e verões secos. Cabe ressaltar, entretanto, que o método, adaptado para as condições climatológicas brasileiras, tem sido largamente aplicado pela sua praticidade em temos da disponibilidade dos dados requeridos (precipitação e temperatura), da facilidade dos cálculos e dos bons resultados geralmente obtidos. A descrição detalhada dos procedimentos do método pode ser encontrada em CAMARGO (1960).

Vários autores consideram o método de Thornthwaite para o cálculo da evapotranspiração potencial como bastante fidedigno. Dentre estes cita-se SETZER (1976), em sua carta "Atlas da evapotranspiração efetiva no Estado de São Paulo". Aquele autor realizou comparações entre os valores calculados por sua fórmula própria e os calculados pelo método Thornthwaite, encontrando uma diferença pequena entre estes valores na região do planalto, salientando ainda que a fórmula de Thornthwaite foi a que apresentou melhores resultados, em relação a outras comparadas. $O$ autor admite ainda que o método de Thornthwaite fornece não a evapotranspiração potencial que promete, mas sim valores muito próximos da efetiva.

A estimativa da evapotranspiração potencial pode também ser feita através de métodos analíticos (o mais utilizado é o de Penman, que envolve o cálculo do balanço de radiação e do transporte vertical turbulento do vapor d'água), de métodos que envolvem relações empiricas e através de medida de evaporação. 
Os resultados do balanço hídrico mensal, obtidos partir de dados mensais de precipitação e médias mensais das temperaturas médias diárias, estão apresentados na Tabela 18, e na Figura 18 estes resultados são representados graficamente.

Os dados de precipitação diária foram os registrados no Posto Pluviométrico Água Branca, situado dentro da área de estudos, pertencente ao DAEE e os de temperatura diários, do posto Meteorológico mais próximo - Mirante Santana - fornecidos pelo INMET.

\begin{tabular}{lccccccccc} 
Meses & $P$ & ETP & (P-ETP) & ARM & ALT & ETR & DEF & EXC & ESC \\
\hline Out/94 & 93 & 88 & 5 & 5 & 5 & 88 & 0 & 0 & 0 \\
Nov/94 & 124 & 93 & 31 & 36 & 31 & 93 & 0 & 0 & 0 \\
Dez/94 & 284 & 118 & 166 & 100 & 64 & 118 & 0 & 102 & 51 \\
Jan/95 & 376 & 125 & 251 & 100 & 0 & 125 & 0 & 251 & 151 \\
Fev/95 & 395 & 99 & 296 & 100 & 0 & 99 & 0 & 296 & 223 \\
Mar/95 & 251 & 93 & 158 & 100 & 0 & 93 & 0 & 158 & 190 \\
Abr/95 & 49 & 72 & -23 & 77 & -23 & 72 & 0 & 0 & 95 \\
Mai/95 & 61 & 56 & 5 & 82 & 5 & 56 & 0 & 0 & 48 \\
Jun/95 & 41 & $\mathbf{4 5}$ & -5 & 77 & -5 & $\mathbf{4 6}$ & 0 & 0 & 24 \\
Jul/95 & 67 & 58 & 9 & 86 & 9 & 58 & 0 & 0 & 12 \\
Ago/95 & 22 & 73 & -51 & 35 & -51 & 73 & 0 & 0 & 6 \\
Set/95 & 55 & 61 & -6 & 29 & -6 & 61 & 0 & 0 & 3 \\
\hline TOTAL & $\mathbf{1 8 1 8}$ & $\mathbf{9 8 2}$ & $\mathbf{8 3 6}$ & & $\mathbf{2 9}$ & $\mathbf{9 8 2}$ & $\mathbf{0}$ & $\mathbf{8 0 7}$ & $\mathbf{8 0 2}$ \\
\hline
\end{tabular}

Valores em $\mathrm{mm}$

P:precipitação;

ETP: evapotransp. potencial;

ESC: escoamento (infiltraçăo + runoff);

ETR:evapotranspiração real;

DEF: deficit hidrico;
ALT: alteração do armazenamento ARM: armazenamento (máx:100mm); EXC: excedente hídrico);

TABELAA 18 - Balanço Hídrico 


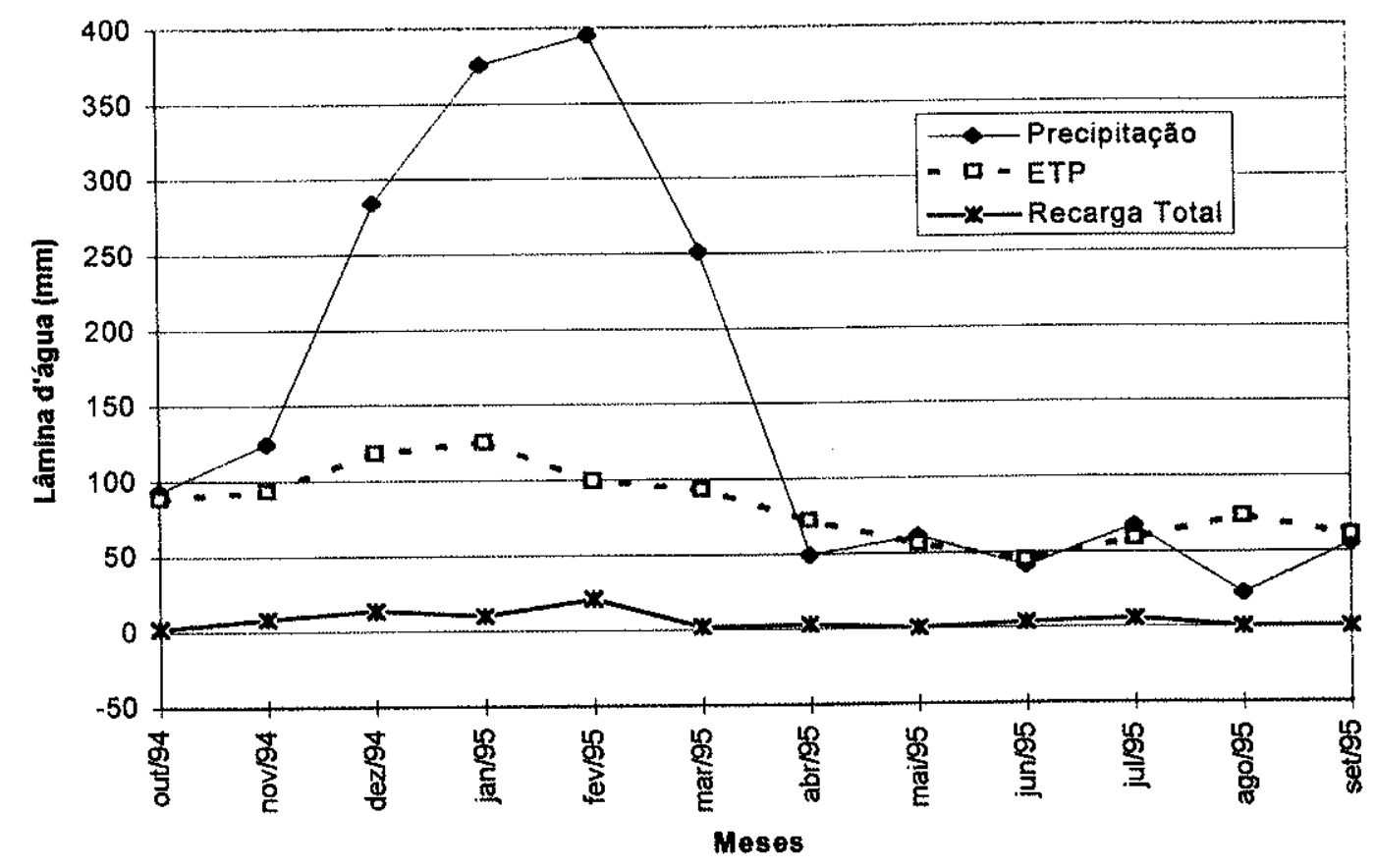

ETP = Evapotranspiração potencial

FIGURA 18 - Balanço hídrico climático

Teoricamente, os resultados do balanço hídrico são considerados satisfatórios quando entre outros, o escoamento (ESC) é igual ao excedente (EXC) e o valor da alteração do armazenamento (ALT) é igual a zero. Entretanto, encontrou-se $A L T=29$ e uma diferença de 5 $\mathrm{mm}$ a favor do EXC. Isto decorreu pelo fato de ter-se considerado um ciclo hidrológico aberto (outubro a setembro), ou seja, não foi avaliado o ciclo hidrológico para o qual o método foi concebido (Janeiro a dezembro). Tal fato explica também a razão do EXC $(807 \mathrm{~mm})$ ser um pouco inferior à diferença (P-ETR), que é de $836 \mathrm{~mm}$. Tal valor corresponde à soma do EXC encontrado com a alteração do armazenamento $(29 \mathrm{~mm})$, que deveria ser nulo. Mesmo assim considerou-se o balanço como satisfatório pois estas variações não foram significativas.

Não obstante o acima exposto, a evapotranspiração potencial obtida foi de 982 $\mathrm{mm} / \mathrm{ano}$, e está de acordo com o resultado do balanço hidrológico simulado pelo DAEE, 1975 para as sub-bacias do Alto Tietê (a montante do posto fluviométrico de itaquaquecetuba), que foi de $940 \mathrm{~mm} / a n$ o, com variação de aproximadamente $20 \%$.

O valor da evapotranspiração potencial obtido $(982 \mathrm{~mm})$, foi coincidente com o da evapotranspiração real (Tabela 18). Isto pode ser ser explicado pelo grande volume precipitado, garantindo armazenamento no solo em todos os meses. 
Cabe ressaltar que estes valores pressupõem condições ideais do solo, conforme o modelo idealizado para o método, ou seja, livre da ocupação urbana e coberto com vegetação graminea, retratando, portanto as condições de pré-ocupação da bacia.

Em síntese, os valores dos componentes hídricos do sistema, na condição de préocupação, para o ano considerado teriam sido:

$P=1818 \mathrm{~mm} ; \quad$ ETP $=$ ETR $=982 \mathrm{~mm} ; \quad$ EXC (Infiltração + Runoff $)=836 \mathrm{~mm}$

Uma avaliação qualitativa dos resultados mensais do balanço hídrico foi realizada lançando-se os valores das recargas mensais no gráfico da Figura 18. Apesar da área encontrar-se intensamente impermeabilizada, verificou-se que existe um bom índice de correlação $(0,80)$ entre os valores de (P-ETP), encontrados para as condições naturais, ou de pré-ocupação da bacia, e a recarga na condição urbana, ou atual.

Verifica-se ainda que nos meses de maio, agosto e setembro, em que a evapotranspiração potencial superou a precipitação, não houve recarga, e que nos meses de junho e abril houve uma recarga modesta, embora o balanço mensal não tenha apresentado deficit hídrico. Estes resultados mostraram que o método do balanço hídrico climático é válido para a estimativa do parâmetros de evapotranspiração real no meio urbano.

Para comparação entre diferentes métodos, a evapotranspiração potencial foi também estimada por meio da conversão dos dados de evaporação mensal, medidos no tanque classe "A" (TUBELIS E NASCIMENTO, 1987, pag. 291). Tal conversão é realizada em função da velocidade do vento a $2 \mathrm{~m}$ de altura, e da umidade relativa.

Os dados de evaporação mensal em tanques classe " $\mathrm{A}$ " compreenderam as médias mensais do periodo de 1975 - 1984 tomados no Posto Meteorológico da Cidade Universitária, controlado pelo DAEE. Obteve-se, por este método, um valor de evapotranspiração potencial de $1088 \mathrm{~mm} / \mathrm{ano}$ (Tabela 19).

\begin{tabular}{ccc} 
MESES & $\begin{array}{c}\text { EVAPORAÇÃo (tanque } \\
\text { classe A) } \\
(\mathbf{m m})\end{array}$ & $\begin{array}{c}\text { EVAPOTRANSPIRAÇÃo } \\
\text { POTENCIAL } \\
\text { (mm) }\end{array}$ \\
\hline Out & 135 & 108 \\
Nov & 125 & 100 \\
Dez & 96 & 76,8 \\
Jan & 81 & 64,8 \\
Fev & 72 & 57,6 \\
Mar & 89 & 71,2 \\
Abr & 101 & 80,8 \\
Mai & 108 & 86,4 \\
Jun & 131 & 104,8 \\
Jul & 141 & 112,8 \\
Ago & 140 & 112 \\
Set & 141 & 112,8 \\
\hline TOTAL & 1360 & 1088 \\
\hline
\end{tabular}

TABELA 19 - Evapotranspiração Potencial a partir de medidas de evaporação medidos em tanque classe $\mathrm{A}$. (Fator de conversão: $\mathbf{0 , 8 0}$ ) 
Há uma boa aproximação entre os valores de evapotranspiração potencial calculados pelos dois métodos (982 $\mathrm{mm}$ pelo método Thornthwaite e $1088 \mathrm{mmpelo}$ método da conversão das medidas do tanque classe A), com uma ligeiro superavit de $9 \%$ em favor do segundo, como já esperado, devido aos exageros que normalmente são encontrados por este método.

\subsubsection{Situação de pós-ocupação da bacia}

A evapotranspiração potencial foi definida por THORNTHWAITE (1955) como a quantidade de água, expressa em altura pluviométrica, que seria transferida da superfície à atmosfera, durante determinado periodo de tempo, em uma área extensa, inteiramente vegetada, onde o solo disponha sempre de umidade suficiente para o uso das plantas. A evapotranspiração é aqui considerada como a perda de água por evaporação do solo não impermeabilizado e transpiração das plantas.

$\mathrm{Na}$ área de estudos os processos de evapotranspiração ocorrem em apenas $27 \%$ da área, que corresponde ao indice de área não impermeabilizada, normalmente coberta por vegetação graminea e arbustos. O valor da evapotranspiração real para a situação de préocupação da bacia, que seria de $982 \mathrm{~mm} / a n$ o (Tabela 18), é então reduzida, proporcionalmente à área não impermeabilizada, para $265 \mathrm{~mm} / \mathrm{ano}$.

$E$ certo que, na situação atual, não somente as áreas com vegetação constituem fontes de vapor à atmosfera, como também as superfícies impermeáveis após a precipitação, entretanto a estimativa desta quantia evaporada é de complexa determinação. A água que é retida nas depressões de telhados e ruas, e eventualmente evaporada, é considerada como fazendo parte das perdas por armazenamento em depressões e por detenção, e a retida por intercepção pelas folhas de árvores e arbustos, são incluídas nas perdas por detenção (CETESB, 1980). Nas áreas intensamente urbanizadas, como no presente caso, as perdas nas depressões de telhados e pavimentação são as mais significativas.

De acordo com o SCS, ocorre uma perda de $20 \%$ por armazenamento em depressões e detenção no início das precipitações, entretanto este indice é muito questionável, pois não são apresentadas informações que fundamentem esta afirmação.

Tabelas com valores de perdas por armazenamento em depressões e por detenção são também propostas pelo CUHP (Colorado Urban Hydrograph Procedure) para cálculo do deflúvio superficial direto. Recomenda-se, nestas tabelas, valores entre 1,3 e 2,5 mm para as superficies impermeáveis para cada evento (CETESB, 1980), conforme apresentado no Quadro 3. 
(mm)

\begin{tabular}{lcc}
\hline Impermeável: & & 2,5 \\
Grandes áreas pavimentadas & $1,3-3,8$ & 2,5 \\
Telhados planos & $2,5-7,6$ & 1,3 \\
Telhados inclinados & $1,3-2,5$ & \\
Permeável: & & 7,6 \\
Terrenos Gramados & $5,1-12,7$ & 10,2 \\
Áreas de florestas e Campos abertos & $5,1-15,2$ & \\
\hline
\end{tabular}

QUADRO 3 - Perdas por Armazenamento em Depressões e por Detenção (CUHP)

A estimativa das perdas por evaporação na área de estudos foi realizada empregandose as perdas recomendadas pelo CUHP. Como cerca de $73 \%$ da área é coberta por telhados e pavimentação domiciliar e viária, adotou-se o valor de $2,0 \mathrm{~mm}$, que representa a média dos valores recomendados para estas áreas, para todos os dias em que houve precipitação acima de $2 \mathrm{~mm}$, que foi de 90 dias (Tabela 1 do Anexo 6). Dessa forma, obteve-se um total retido e evaporado de $182 \mathrm{~mm} / \mathrm{ano}$, que representa um volume de 1,7 $\mathrm{Mm}^{3} / \mathrm{ano}$.

A evaporação reai na situação atual de ocupação da bacia representa, então, a somatória da evaporação das áreas impermeáveis $(182 \mathrm{~mm})$ e permeáveis $(265 \mathrm{~mm})$, que resulta num total de $\mathbf{4 4 7} \mathrm{mm} / \mathrm{ano}$, que representa, $25 \%$ da precipitação anual.

Assim, a redução da recarga direta, em decorrência da impermeabilização da bacia, foi avaliada comparando-se o valor da recarga estimada, de $67,2 \mathrm{~mm}$ (Tabela 17) com a que seria obtida nas condições de pré-ocupaçăo da bacia.

Nas condições atuais, obteve-se que aproximadamente $4 \%$ do precipitado anual tornou-se recarga efetiva em toda bacia, isto é $67,2 \mathrm{~mm}$ dos $1818 \mathrm{~mm}$ precipitados durante o ano (Tabela 17) infiltrou-se nos $27 \%$ da área livre da impermeabilização.

Supondo-se a bacia em condições naturais (pré-ocupação), encontrar-se-ia, por meio de uma proporção direta entre o valor de recarga obtido $\left(67,2 \mathrm{~mm}\right.$ ou $\left.0,64 \mathrm{Mm}^{3} / \mathrm{ano}\right)$ e a sua área de infiltração $\left(2,6 \mathrm{~km}^{2}\right)$, uma recarga anual de $258 \mathrm{~mm}\left(2,5 \mathrm{Mm}^{3}\right)$, ou seja, $14 \%$ da precipitação anual. A urbanização teria provocado, assim, uma redução de $191 \mathrm{~mm}$, correspondente a $\mathbf{7 5 \%}$ do volume que poderia ser infiltrado no aqüifero freático, nas condições da bacia natural.

As alterações quantitativas dos recursos hídricos na bacia atual até aqui apresentadas encontram-se sintetizadas na Tabela 20 , onde se verificam as fontes de entrada e as saídas do sistema hidrológico da área. Do total que entrou no sistema (2350 mm/ano, ou 22,5 
$\mathrm{Mm}^{3} / \mathrm{ano}$ ), 23\% (532 mm/ano, ou $5,11 \mathrm{Mm}^{3}$ ) são provenientes dos vazamentos da rede de abastecimento, os quais são responsáveis por $89 \%$ da recarga total $\left(599 \mathrm{~mm} / \mathrm{ano}, 5,75 \mathrm{Mm}^{3}\right)$.

\begin{tabular}{lccc}
\multicolumn{1}{c}{$\begin{array}{c}\text { COMPONENTES DO } \\
\text { SISTEMA } \\
\text { HiDROLÓGICo }\end{array}$} & ENTRADAS & RECARGA & SAÍDAS \\
\hline $\begin{array}{l}\text { Precipitação }(\mathrm{mm}) \\
\text { Infiltação direta }(\mathrm{mm})\end{array}$ & 1818 & 67 & \\
$\begin{array}{l}\text { Infiltração indireta }(\mathrm{mm}) \\
\text { Evapotranspiração } \\
\text { retenção }(\mathrm{mm})\end{array}$ & 532 & 532 & 447 \\
Runoff $(\mathrm{mm})$ & & & 1290 \\
\hline TOTAL & $\mathbf{2 3 5 0}$ & $\mathbf{5 9 9}$ & $\mathbf{1 7 3 7}$ \\
\hline
\end{tabular}

TABELA 20 - Balanço das entradas e saídas dos recursos do sistema hídrológico atual.

As Figuras 19 e 20 ilustram a distribuição dos componentes do balanço hídrico nas situações de pré-ocupação e ocupação urbana. 


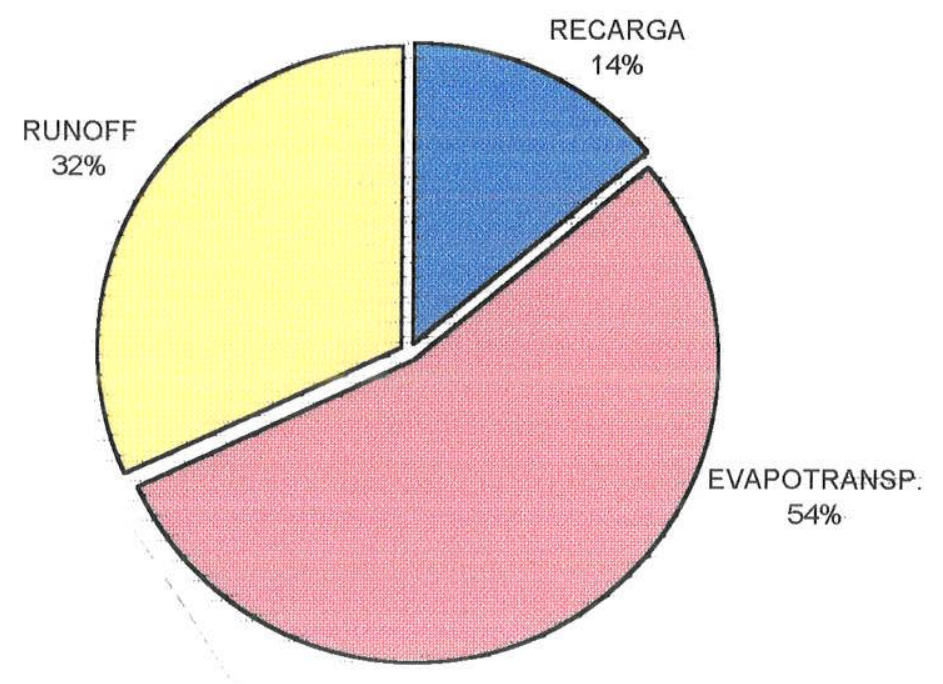

FIGURA 19 - Relação entre os componentes do Balanço Hídrico na situação de préocupação da bacia. (Vatores em relação à precipitação anual)

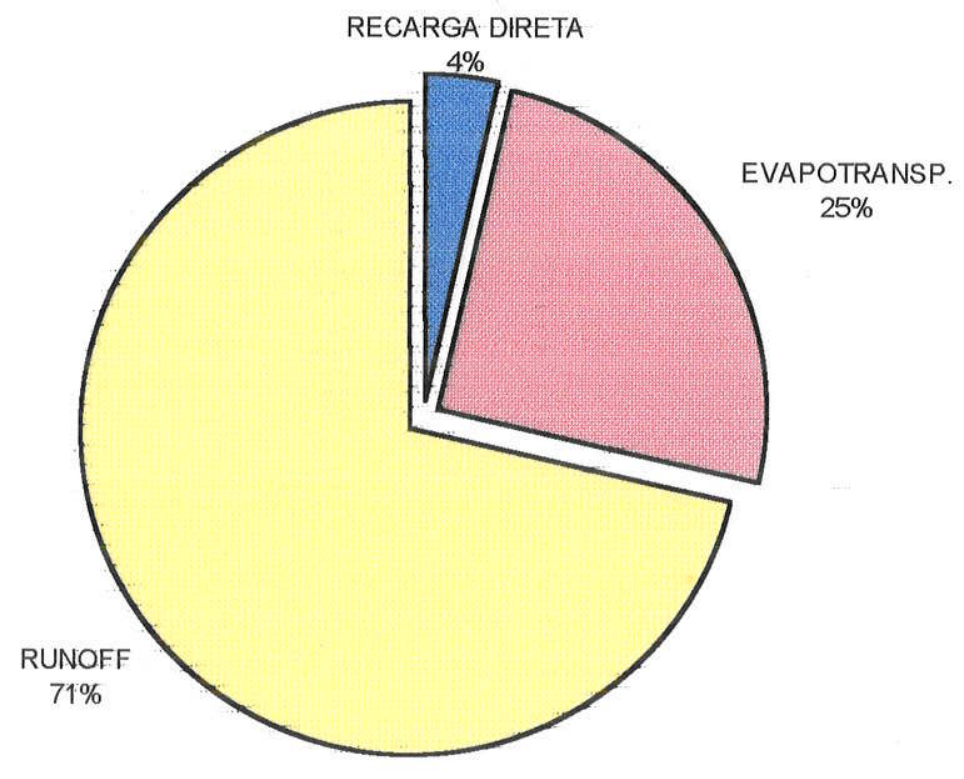

FIGURA 20 - Relação entre os componentes do Balanço Hídrico na bacia urbanizada (Valores em relação à precipitação anual) 


\subsection{CARACTERIZAÇÃO QUIMICA DAS ÁGUAS DO AQÜÍFERO FREÁTICO}

A qualidade das águas do aqüífero freático foi analisada por meio da caracterização quimica e físico-química das águas, principalmente para avaliação do grau e dos tipos de poluição inorgânica eventualmente existentes.

Os resultados dos parâmetros químicos referentes aos poços de monitoramento são apresentados na Tabela 2 do Anexo 6, e os referentes às nascentes na Tabela 3 do Anexo 6. Os parâmetros analisados foram os ions maiores $\left(\mathrm{Cl}^{-1}, \mathrm{NO}_{3}{ }^{-1}, \mathrm{SO}_{4}{ }^{-2}, \mathrm{HCO}_{3}{ }^{-1}, \mathrm{Ca}^{+2}, \mathrm{Mg}^{+2}, \mathrm{Na}^{+1}\right.$, $\mathrm{K}^{+1}$ ) e os metais $\mathrm{Al}, \mathrm{Zn}, \mathrm{Fe}, \mathrm{Cu}, \mathrm{Fe}$ (total). Foram realizadas quatro coletas no período do estudo.

Os valores em negrito nas tabelas acima referidas correspondem aos teores acima dos limites de potabilidade para consumo humano, segundo a Organização Mundial de Saúde in CETESB (1990). Dentre esses, os mais freqüentes nas águas dos poços de monitoramento referem-se a: $\mathrm{NO}_{3}{ }^{\circ}, \mathrm{Fe}, \mathrm{Al}, \mathrm{Pb}$ e $\mathrm{Mn}$.

$\mathrm{O} \mathrm{Pb}$ e $\mathrm{Zn}$ aparecem com elevadas concentrações em 4 poços, sendo que em dois deles (Poços 13 e 5) constatou-se haver forte cheiro de gasolina, cuja procedência seriam os vazamentos dos tanques de dois postos situados a menos de $50 \mathrm{~m}$ a montante de cada um desses poços.

Dentre os ions que se apresentam acima dos limites de potabilidade, $\circ \mathrm{NO}_{3}{ }^{-1}$ é o mais freqüente, tanto nos poços quanto nas nascentes, provavelmente associados a vazamentos das redes de esgoto.

Os valores de pH observados nos poços (Figura 21) e nascentes (Figura 22) são caracteristicamente baixos, situando-se entre 4 e 7, refletindo a influência do pH das águas de chuva e de compostos ácidos nas primeiras camadas do solo. SZIKSZAY (1993) apresentou valores de pH para diversas regiōes do Estado de São Paulo, encontrando 4,99 no município de São Paulo (Cidade Universitária). Valores similares a 4,7, são encontrados nas áreas urbanizadas e industrializadas da América do Sul, como as cidades de São Paulo e Rio de Janeiro (GALVÃO, 1996).

Observou-se que os valores de $\mathrm{pH}$ variaram de local para local, apresentando discreta tendência à elevação nos meses úmidos (melhor observada entre dezembro/94 e março/95), e diminuição nos meses secos. As variações locais indicam as diversidades litológicas, e o abrandamento nos meses secos reforçam a influência da precipitação, mais ácida na época de baixa umidade, devido ao aumento da poluição atmosférica nesta época. MATSCHULLAT (1992), cita que o $\mathrm{pH}$ natural da chuva $(5,6)$ é nitidamente reduzido a 4,0 , em regiões nos Estados Unidos em outros locais do mundo, em decorrência da poluição atmosférica urbana. 


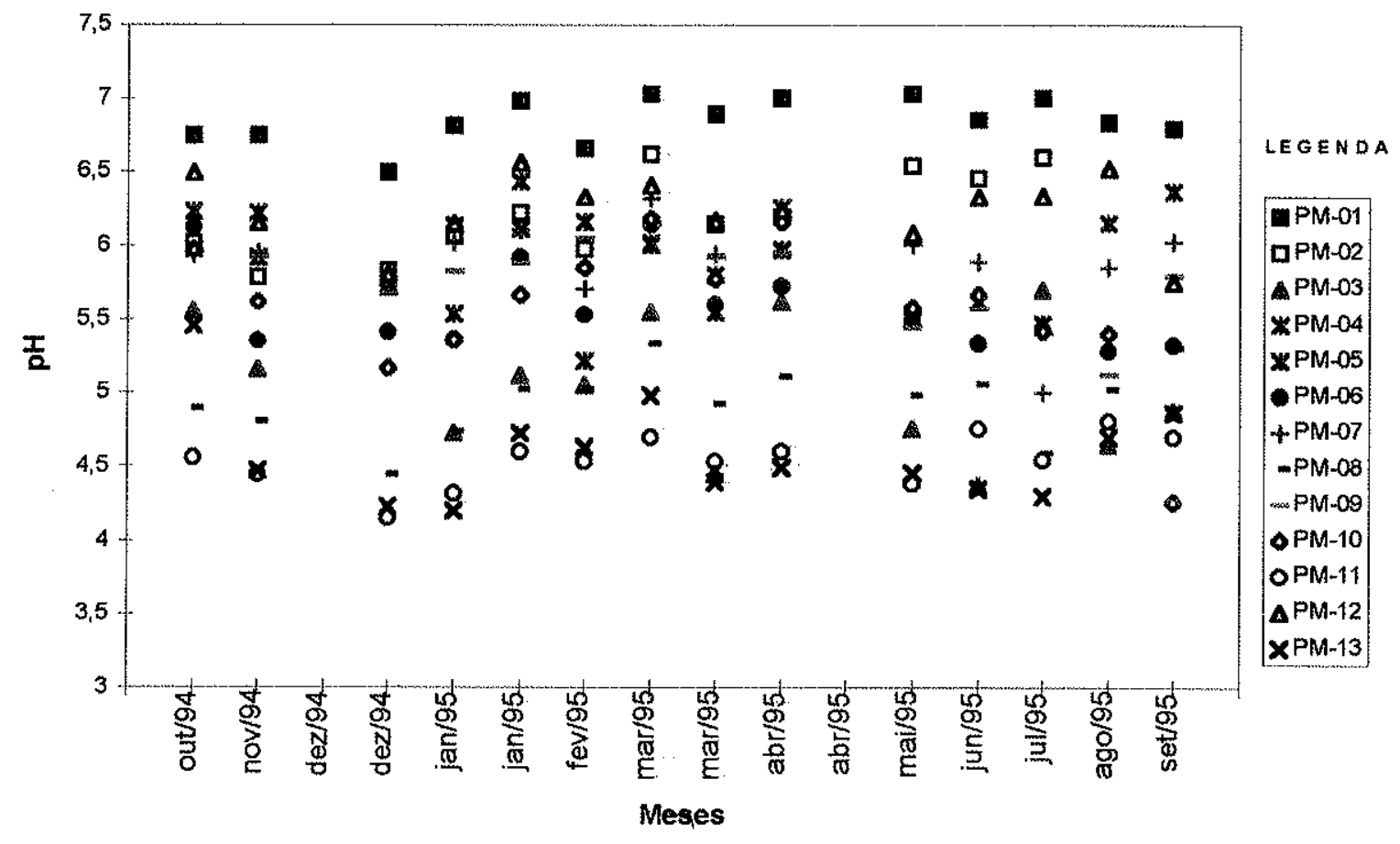

FIGURA 21 - Variações do pH - Poços de Monitoramento

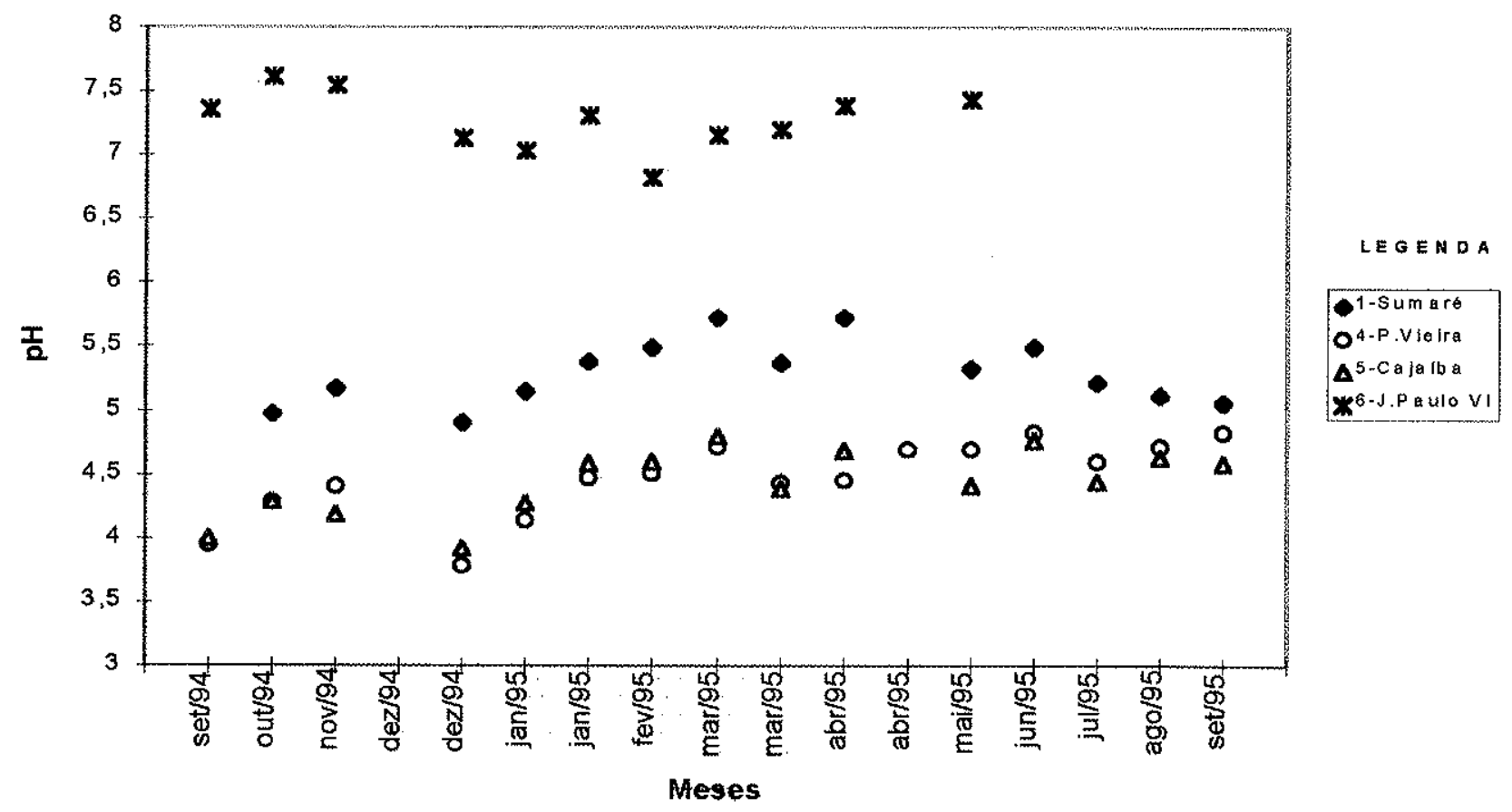

FIGURA 22 - Variações do pH - Nascentes 
Nas nascentes, os valores da condutividade elétrica apresentaram-se baixas, variando entre 110 e $250 \mu \mathrm{S} / \mathrm{cm}$ (Figura 23), indicando a rápida circulação das águas nas áreas de descarga local.

Nos poços de monitoramento, os valores da condutividade elétrica foram mais elevados no terreno quaternário (Figura 24), chegando ao limite de $1700 \mu \mathrm{S} / \mathrm{cm}$ (Poços 1, 2, 4 e 7). As melhores condições de armazenamento, aumentando o tempo de contato solo-água devido ao baixo gradiente hidráulico $(0,0065)$, e a presença natural de argila orgânica justificam estes valores elevados.

No domínio do terreno terciário, a condutividade elétrica apresentou-se mais baixa do que no terreno quaternário, com valores próximos aos encontrados nas nascentes, oscilando entre 50 e $300 \mu \mathrm{S} / \mathrm{cm}$, confirmam boas condições de circulação com menor tempo de permanência da água armazenada no aqüífero.

Tendências de variações durante o ano podem ser observadas visualmente na Figura 24, somente nas nascentes, que apresentaram elevações nos meses úmidos, e diminuição no periodo seco. O fato desta tendência verificar-se somente nas nascentes mostra que as frentes iniciais da infiltração, são mais carregadas de sais originados das primeiras camadas do solo. As águas das nascentes apresentam, assim, a salinização adquirida nos processos iniciais da infiltração. 


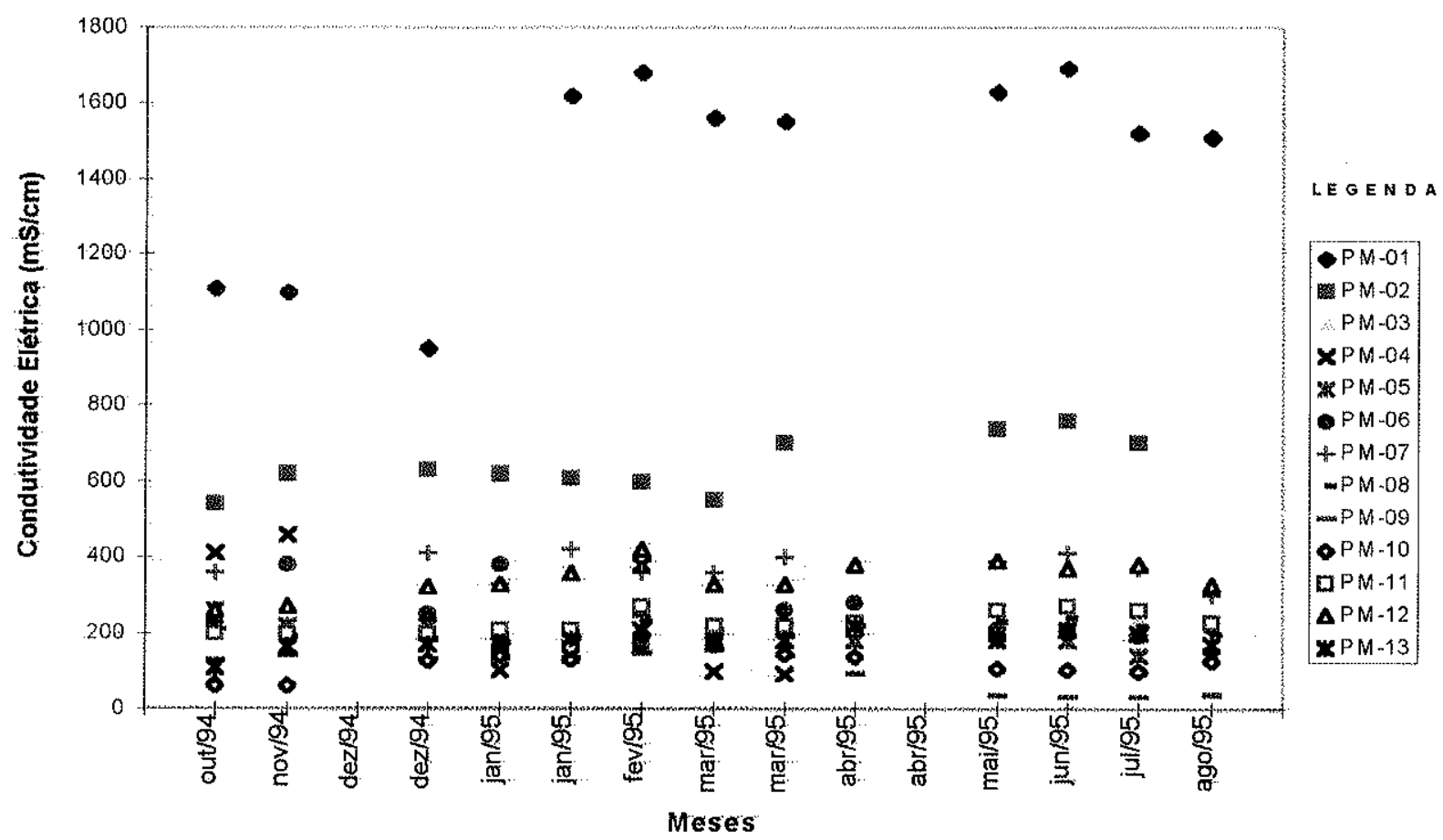

FIGURA 23 - Variações da Condutividade Elétrica - Poços de Monitoramento

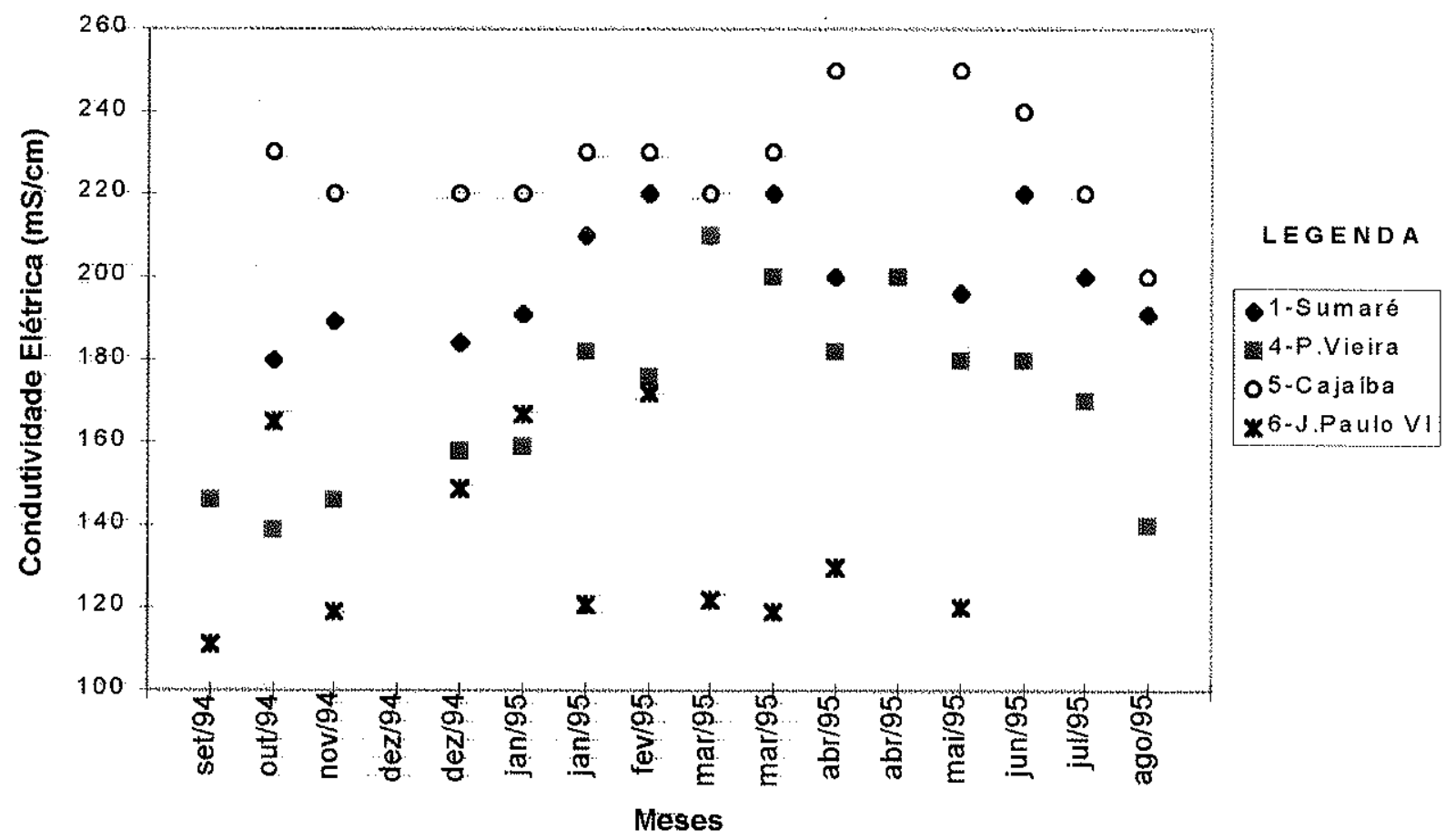

FIGURA 24 - Variações da Condutividade Elétrica - Nascentes 


\section{ESCOAMENTO SUPERFICIAL}

\subsection{CONSIDERAÇÕES}

A conseqüência da impermeabilização urbana foi abordada, numa escala anual, com relação à recarga natural do aqüifero freático, tendo sido estimada uma redução anual de $75 \%$ após a urbanização da bacia aos níveis atuais.

O aumento do volume do escoamento superficial, principal responsável pelas enchentes urbanas, é a conseqüência observável numa escala de tempo em nivel de minutos ou horas, ocorrendo quase simultaneamente aos eventos de chuva.

As principais medidas de controle de enchentes no meio urbano foram abordadas no item 2.3.1. As medidas de controle na fonte (source control) são formas de combate às enchentes com a finalidade de promover a infiltração no seu local de incidência (pavimentos porosos, cobertura vegetal, valas de infiltação, etc) e ou reter temporária ou permanentemente parte do volume escoado em reservatórios domiciliares para posterior reutilização. Estes reservatórios podem também possuir uma combinação das duas funções, de infiltração e de armazenamento. Tais medidas, visam à redução do pico do escoamento superficial, distribuindo a vazão no tempo, sendo denominadas de medidas estruturais não convencionais por CANHOLI (1995).

As freqüêntes inundações que atingem o município de São Paulo, impulsionaram o governo municipal a criar a Lei $n^{\circ} 11.228$ de 25 de junho de 1992, que dispõe sobre medidas de retenção do escoamento superficial na fonte, incluindo a construção de reservatórios domiciliares que permitem a infiltração e a retenção temporária do volume captado.

Neste estudo foi avaliada, com base nas características litológicas e hidráulicas dos solos da área, o volume mínimo ideal que deveria ser retido mediante a construção dos reservatórios previstos em lei, em toda a área de estudos. Tal volume foi admitido como sendo a quantidade de água infiltrada naturalmente antes da ocupação das bacias.

Este volume foi comparado com a capacidade máxima de detenção dos reservatórios, de acordo com o dimensionamento previsto pela legislação, visando avaliar a sua eficácia.

Os métodos empregados nos cálculos são indiretos, os clássicos adotados na hidrologia urbana, uma vez, que não se dispõe de dados reais de chuva-vazão.

O estudo apresenta-se na seguinte seqüência: breve histório da legislação específica; caracterização da ocupação da área; estudo do escoamento superficial direto, envolvendo a infiltração atual e teoricamente infiltrada e a infiltração potencial nas condições de préocupação das bacias; caracterização dos níves de ocupação na área e a capacidade de armazenamento dos micro-reservatórios. 


\subsection{A LEI MUNICIPAL}

\subsubsection{Histórico}

Em 10 de novembro de 1989 foi decretada a Lei municipal $n^{\circ} 10.774$, que dispunha sobre a absorção de águas pluviais nos lotes. A regulamentação desta lei, de competência da Comissão Especial de Uso do Solo (CEUSO), só foi publicada em 03 de abril de 1992 (Resolução CEUSO 60/92, p. 47).

Em síntese, a regulamentação da lei teve como pontos básicos:

- a definição dos seguintes dipositivos destinados à captação, retenção e absorção das águas pluviais:

a) reserva de, no mímino $15 \%$ da área do terreno livre da pavimentação ou construção;

b) a construção de micro-reservatório de ligado ao sistema de absorção, sendo a capacidade de absorção do solo determinada conforme critérios fixados pela Norma NBR7229 da ABNT;

c) a construção de caixas de retardamento iguaimente ligadas ao sistema de absorção, conforme citado no parágrafo anterior. A definição das caixas de retardamento será apresentada mais adiante.

- a equação do dimensionamento dos dispositivos citados nos itens " $b$ " e " $c$ ", baseado no índice pluviométrico adotado, na área total do lote e na sua fração impermeável.

- estabeleceu o tempo de uma hora após o término da chuva, as águas não absorvidas durante o período de chuva pelos sistemas previstos (micro-reservatório e caixa de retardamento), deveriam ser encaminhadas ao sistema público de escoamento de águas pluviais.

- desobrigou de obediênica à lei, caso constatada a impermeabilidade do solo nos seguintes casos:

a) área do lote menor ou igual a $250 \mathrm{~m}^{2}$;

b) comprovação técnica da capacidade de absorção do solo, de acordo com as Normas Técnicas Oficiais (NTO), para lotes com área maior do que $250 \mathrm{~m}^{2}$.

c) quando o alvará de construção ou de reforma tiver sido expedido anteriormente à publicação da Lei 10.774/89."

A Lei 10.774 de 10 de novembro de 1989, foi, entretanto revogada pela Lei Municipal 11.228 de 25 de junho de 1992 (Novo Código de Edificações do Município de São Paulo COE) e Decreto Municipal 32.329 de 24 de setembro de 1992. O texto da lei anterior 
(10774/89) foi modificado e inserido, de forma mais simplificada, no item 10.1 .5 do COE, com os seguintes dizeres:

“10.1.5 As condições naturais de absorção das águas pluviais no lote deverão ser garantidas pela execução de um ou mais dos seguintes dispositivos:

a) reserva de, no minimo, $15 \%$ (quinze por cento) da área do terreno livre de pavimentação ou construção;

b) construção de resenvatório ligado a sistema de drenagem.

10.1.5.1 Na hipótese de utilização de piso drenante para atendimento à letra "a", apenas sua área efetivamente vazada será considerada como livre de pavimentação.

10.1.5.2 Considera-se reservatório qualquer dispositivo dimensionado de acordo com a fórmula:

onde:

$$
V=0,15(S-S p) \times I P \times t
$$

$V=$ volume do dispositivo adotado;

$S=$ área total do terreno;

$S p=$ área do terreno livre de pavimentação ou construção;

$I P=$ indice pluviométrico igual a $0,06 \mathrm{~m} / \mathrm{hora}$;

$t=$ tempo de duração da chuva igual a 1 (uma hora).

10.1.5.3 O volume de água captado e não drenado em virtude da capacidade de absorção do solo, determinado conforme critérios fixados pelas NTO, deverá ter seu despejo no sistema público de águas pluviais retardado, para tão logo este apresente condições de receber tal contribuição."

E no Anexo 10:

"10.A.4 - As disposições naturais de absorção das águas pluviais no lote deverão se garantidas, conforme item 10.1.5 do COE.

10.A.4.1 - Considera-se reservatório qualquer dispositivo de retenção e acumulação das águas pluviais podendo ser, dentre outros, o volume acima do nivel d'água das piscinas e espelhos d'água e 1/3 (um terço) do volume das floreiras e jardins sobre a laje.

10.A.4.2 - A absorção das águas pelo sistema de drenagem deverá ser dimensionada conforme Normas Técnicas Oficiais (NTO)."

\subsubsection{Interpretação da lei}

Os dispositivos legais acima apresentados constituem as medidas de controle na fonte, ou seja, a montante dos locais das enchentes. 
A lei torna obrigatória a opção por uma das duas alternativas, que prevêem o retardo ou a absorção das águas pluviais dentro do lote:

O dispostivo "a" estabelece a reserva de não menos que $15 \%$ da área do lote para infiltração direta da precipitação, devendo, portanto, ficar livre da cimentação ou construção, a área correspondente a este índice.

O dispositivo "b" prevê como alternativa de retenção da água, a construção de um reservatório, cuja capacidade máxima é calculada de acordo com a expressão citada naquele parágrafo, e que seria posteriormente despejado na rede pública de águas pluviais.

O termo (S-Sp) representa a área impermeável do terreno, ou seja a área ocupada pela construção e pela cimentação. Assim, o volume do reservatório é o equivalente a $15 \%$ do volume precipitado na área impermeável do lote, considerando-se para tanto, um evento crítico com intensidade de $0,06 \mathrm{~m} / \mathrm{h}(1 \mathrm{~mm} / \mathrm{min})$ durante 0 período de uma hora, correspondente, de acordo com estudos de MAGNI E MERO (1986), a um periodo de retorno $\mathrm{Tr}=10$ anos.

A lei não é explicita quanto aos aspectos construtivos do reservatório, entretanto, pelo item 10.1.5.3, fica subentendido que os eles devem possuir condições para drenagem no solo durante o seu enchimento.

\subsection{ESCOAMENTO SUPERFICIAL DIRETO}

O produto da lâmina de chuva excedente $\left(h_{\text {exc }}\right)$ pela área de drenagem (AD), fornece o volume de escoamento superficial direto.

Diversos métodos podem ser aplicados para a determinação do escoamento superficial (ou precipitação efetiva), principal responsável pelas inundações, especialmente em bacias pequenas e urbanizadas.

Em hidrologia urbana, o método clássico è o do coeficiente de escoamento superficial direto (C), em que simplesmente se admite que uma fração da precipitação total se constitui no escoamento superficial. A aplicação prática deste coeficiente, limita-se a bacias de ocupação homogênea, menores que $100 \mathrm{ha}\left(1000 \mathrm{Km}^{2}\right)$, e intensidades de chuva com períodos de retorno entre 5 - 10 anos.

Os métodos existentes, classificados em ordem decrescente de rigor teórico são: (a) equações de infiltração (Horton; Green e Ampt); (b) Relações funcionais (método do Soil Conservation Service - SCS); (c) indices (indice de $\mathrm{Fi}$ );

Neste estudo foi utilizado o programa ABC4 - Análise de Hidrogramas de Cheias em Bacias Complexas (PORTO, 1991), tendo sido empregado a Equação de Horton para cálculo 
da precipitação excedente e o de Santa Bárbara para realização do hidrograma. A fundamentação teórica e os parâmetros destes métodos são mostrados a seguir.

\section{Método de Horton (1939)}

Horton (in TUCCI 1993), estabeleceu, para a situação de um solo submetido a uma precipitação com intensidade sempre superior à capacidade de infiltração, uma relação empírica para representar o decaimento da infiltração com o tempo, assim representada:

$$
I_{t}=I_{b}+\left(I_{i}-I_{b}\right) e^{-k t}
$$

onde:

$\mathrm{t}=$ tempo decorrido desde a saturação superficial do solo;

$\mathrm{I}_{\mathrm{t}}=$ taxa de infiltração no tempo $\mathrm{t}$;

$\mathrm{I}_{\mathrm{b}}=$ taxa mínima de infiltração;

$l_{i}=$ taxa de infiltação inicial $(t=0)$;

$k=$ parâmetros de ajuste da equação nos pontos $1 \times t$ medidos em ensaios de campo.

A taxa mínima de infiltração $l_{b}$ teoricamente seria igual à condutividade hidráulica

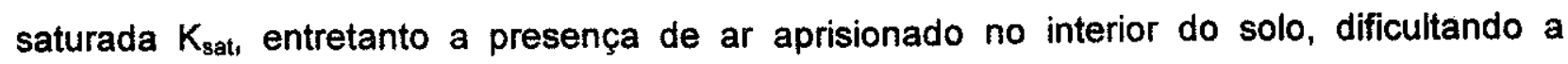
infiltração, torna $l_{b}$ normalmente menor que $K_{\text {sat, }}$

Os parâmetros $I_{b}, l_{i}$ e $K$ são empíricos e de difícil estimativa em locais sem informações experimentais, o que limita muito a aplicação do método. Entretanto, Morel-Seitoux estabeleceram a correspondência entre os parâmetros de Horton e as caracteristicas físicas do solo e também as relações entre estes parâmetros e os valores de CN (Curve Number) tabelados peio SCS, em função da ocupação e tipo hidrológico do solo.

O fator $\mathrm{CN}$ foi tabelado para diferentes tipos de solo, tipo de cobertura (uso), e umidade antecedente, sendo que a escala (de 1 a 100), variando desde uma cobertura muito impermeável (limite inferior) até uma cobertura completamente permeável (limite superior).

O SCS distingue quatro grupos hidrológicos de solos, conforme apresentados no Quadro 4 (in PORTO, 1995).

\begin{tabular}{|c|c|c|c|c|}
\hline $\begin{array}{c}\text { PARAMETROS DA EQUAÇAO } \\
\text { DE HORTON }\end{array}$ & \multicolumn{3}{|c|}{ CLASSIFICAÇÁO HIDROLÓGICA DO SOLO } \\
\hline & Tipo A & Tipo B & Tipo C & Tipo $D$ \\
\hline$l_{i}(\mathrm{~mm} / \mathrm{h})$ & 250 & 200 & 130 & 80 \\
\hline$l_{b}(\mathrm{~mm} / \mathrm{h})$ & 25 & 13 & 7 & 3 \\
\hline$k$ & 2 & 2 & 2 & 2 \\
\hline
\end{tabular}

QUADRO 4 - Correspondência entre os parâmetros de Horton e o tipo hidrológico do solo (PORTO, 1995) 
GRUPO A - Solos arenosos com baixo teor de argila total, inferior a $8 \%$, não havendo rocha nem camadas argilosas, e nem mesmo camadas densificadas até a profunidade de 1,5 m. O teor de húmus é muito baixo, não atingindo $1 \%$.

GRUPO B - Solos arenosos menos profundos que os do Grupo A e com menor teor de argila total, porém ainda inferior a $15 \%$. No caso de terras roxas, esse limite pode subir a $20 \%$ graças à maior porosidade. Os dois teores de húmus podem subir, respectivamente, a 1,2 e $1,5 \%$. Não pode haver pedras e nem camadas argilosas até $1,5 \mathrm{~m}$, mas é, quase sempre, presente camada mais densificada que a camada superficial.

GRUPO C - Solos barrentos com teor total de argila de 20 a $30 \%$, mas sem camadas argilosas impermeáveis ou contendo pedras até profundidades de 1,2 $\mathrm{m}$. No caso de terras roxas, esses dois limites máximos podem ser de $40 \%$ e $1,5 \mathrm{~m}$. Nota-se, a cerca de $60 \mathrm{~cm}$ de profundidade, camada mais densificada que no Grupo B, mas ainda longe das condições de impermeabilidade.

GUPO D - Solos argilosos (30-40\% de argila total) e ainda com camada densificada a uns $50 \mathrm{~cm}$ de profundidade. Ou solos arenosos como $\mathrm{B}$, com camada argilosa quase impermeável, ou horizonte de seixos rolados.

A fim de que a equação de Horton possa ser aplicada qualquer que seja a intensidade de chuva, é necessário que seja determinada a capacidade de infiltração em função da quantidade de chuva anteriormente infiltrada $(V)$. O valor de " $V$ " em mm é obtido integrandose a equação anterior com relação ao tempo:

$$
V=\frac{I_{1}-I_{b}}{k}\left(1-e^{-k t}\right)+I_{b} \cdot t
$$

onde:

$V=$ volume infiltrado acumulado, até o tempo $t$, contando a partir do momento da saturação superficial do solo.

O valor de $l_{b}$ seria atingido quando $t$ tender a infinito, para a condição de saturação total do solo, ou seja, $l_{b}$ seria igual à condutividade hidráulica saturada.

A equação de Horton evidentemente é válida para a parte permeável da bacia. Em áreas urbanas, é necessário considerar-se também as parcelas impermeáveis diretamente conectadas (DC) e as indiretamente conectadas (IC), cujos escoamentos oriundos destas frações, bem como da parte permeável, são calculados pelo programa ABC4.

A Área Impermeável Diretamente Conectada é a fração da bacia que despeja as águas pluviais diretamente na rede de drenagem, sem que existam perdas entre o ponto em que a precipitação atinge a superfície e a saída da bacia. A Área Impermeável Indiretamente Conectada é a que despeja as águas coletadas em áreas permeáveis, possibilitando, assim, 
nova oportunidade de infiltração (por exemplo: telhados que despejam as águas pluviais diretamente em jardins).

\section{O método de Santa Bárbara}

Foram elaborados hidrogramas de escoamento superficial direto, os quais são gerados pela tranformação dos incrementos de chuva de cada intervalo de tempo. $O$ método escolhido, pela sua praticidade em relação aos parâmetros requeridos, foi o de Santa Bárbara, o qual consta no programa ABC4.

O método admite que o hidrograma de saida de uma bacia possa ser obtido pelo trånsito (routing) de um hidrograma instantâneo de entrada, através de um reservatório linear imaginário, cuja constante é igual ao tempo de concentração da bacia $\left(t_{c}\right)$. A descrição detalhada do método encontra-se fora do escopo deste estudo, sendo corrente na literatura.

\subsubsection{Parâmetros das sub-bacias}

Foram estudadas duas condições de ocupação das sub-bacias: natural (pré-ocupação, admitindo-se uma cobertura de gramíneas) e urbana (pós-ocupação).

A condição natural foi considerada para obter-se a quantidade infiltrada naturalmente antes da ocupação, admitindo-se este, como valor mínimo do escoamento a ser amortecido. nas condiçōes atuais de ocupação.

O volume do escoamento superficial direto foi calculado utilizando-se o evento crítico de chuva apresentado na lei municipal, na equação para dimensionamento dos microreservatórios $(P=60 \mathrm{~mm} ; \mathrm{l}=1 \mathrm{~mm} / \mathrm{min} ; t=1$ hora; $\mathrm{Tr}=10$ anos $)$.

Os parâmetros das sub-bacias consideradas, requeridos pelo programa $\mathrm{ABC} 4$ são:

\section{Condição Natural}

Parâmetros:

\section{Pompéia}

1. Área da bacia:

2. Número da curva (da parte permeável): 80

3. Fraçăo Impermeável:

4. Fração Diretamente Conectada:

5. Tempo de Concentração:
$5,1 \mathrm{~km}^{2}$

0,0

0,0

$1,0 \mathrm{~h}$
Sumaré

$4,5 \mathrm{~km}^{2}$

80

0,0

0,0

$1,0 \mathrm{~h}$ 
Condição urbanizada

1. Área da bacia:

2. Número da curva (da parte permeável): 80

3. Fração Impermeável:

4. Fração Diretamente Conectada:

5. Tempo de Concentração:

\section{Pompéia}

$5,1 \mathrm{~km}^{2}$

0,73

0,60

0,75
Sumaré

4,5

80

0,73

0,60

0,75

Observaçōes:

- o valor de $t_{c}$ (tempo de concentração) da bacia natural foi obtido pela fórmula de Kirpich \| (1942), cujos parâmetros para o cálculo são: L (comprimento do canal), H (diferença de cotas):

$$
\text { tc }=57 \times \mathrm{L}^{1,155} \times \mathrm{H}^{-0,385}
$$

onde:

$\begin{array}{llll}\text { Para bacia do Sumaré, } & L=4,0 \mathrm{~km} & \text { e } & H=55 \mathrm{~m} \\ \text { Para o córrego Agua Preta, } & L=4,5 \mathrm{~km} & \text { e } & H=55 \mathrm{~m}\end{array}$

- o valor de $t_{c}$ na condição urbanizada foi estimado por meio de estudos de subbacias, realizados no municipio de São Paulo pelo CTH/DAEE, cujas dimensões, taxas de impermeabilização e formato das bacias são semelhantes às do estudo.

- o vaior da fração diretamente conectada $(0,6)$ foi assumida como sendo igual à da parte jusante da bacia Pacaembu, adjacente à sub-bacia Sumaré, de ocupação semelhante, conforme apresentada por CANHOLI (1994), em estudo hidrológico, para construção de reservatório de retenção.

\subsubsection{Características da ocupação}

As três zonas de ocupação residencial-comercial-serviços $-Z_{1}, Z_{2}, Z_{3}$ (Quadro 2), constituem a parte montante das sub-bacias em estudo, de onde também é gerada a maior parte do volume do escoamento superficial direto. Uma amostragem da distribuiçăo das dimensões dos lotes é apresenta na Figura 25 para cada uma destas zonas, verificando-se que a maior frequâencia de lotes está entre $100-200 \mathrm{~m}^{2}$ nas zonas $Z_{2} \in Z_{3}$ e de $200-400 \mathrm{~m}^{2}$ na zona estritamente residencial $Z_{1}$.

Pela lei municipal do zoneamento 8001 (1972), ainda vigente, foram estabelecidas as seguintes áreas mínimas para loteamento de uso residencial e comercial:

$Z_{1}-250 m^{2}$ (residencial e comercial);

$Z_{2}-125 \mathrm{~m}^{2}$ (residencial) e $250 \mathrm{~m}^{2}$ (comercial);

$Z_{3}-250 \mathrm{~m}^{2}$ (residencial e comercial). 
Observa-se, em todas as zonas, o não cumprimento da lei do zoneamento, que estabelece a área mínima dos lotes, principalmente na zona $Z_{3}$, onde a maior parte desses são menores que a área mínima estabelecida $\left(250 \mathrm{~m}^{2}\right)$. As zonas $Z_{1}$ e $Z_{2}$, entretanto, possuem a maior parte dos lotes com áreas superiores às mínimas, 250 e $125 \mathrm{~m}^{2}$, respectivamente.

De uma forma geral, os terrenos são bastante reduzidos, o que reforça o aspecto adensado da área e conseqüente acentuação da impermeabilização.

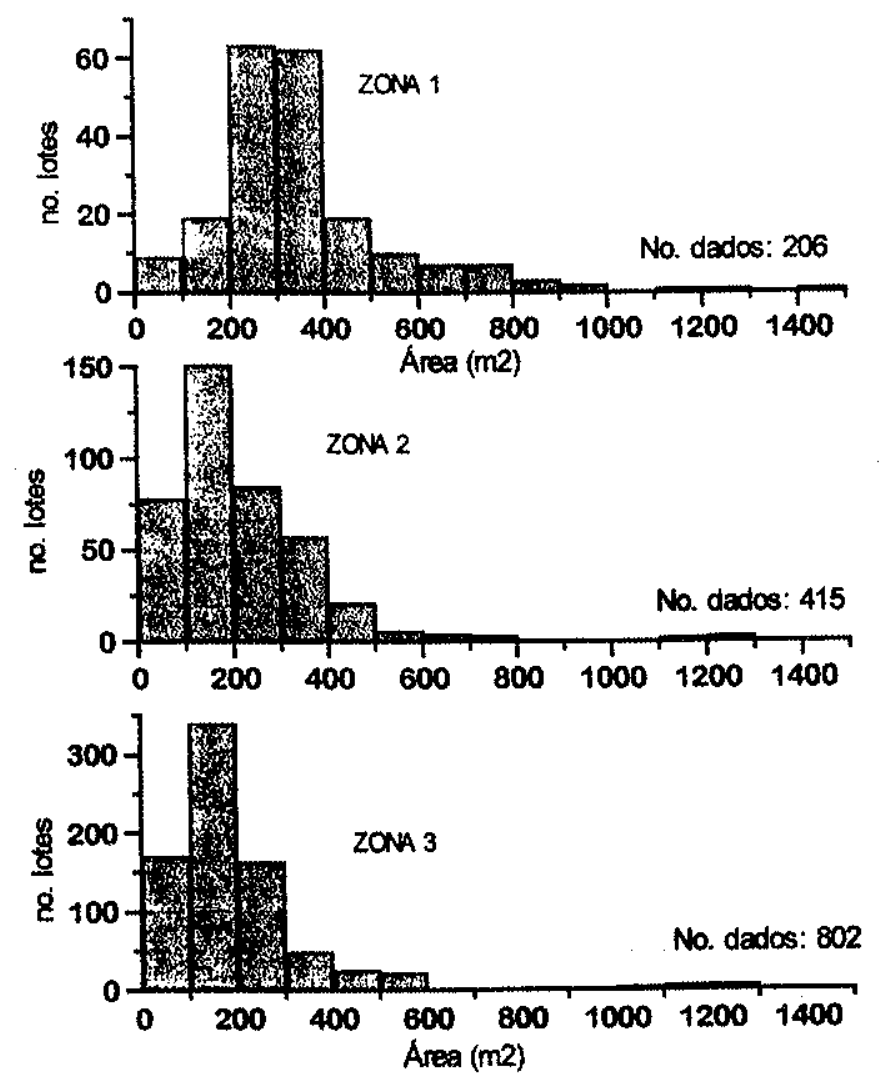

FIGURA 25 - Freqüência das áreas dos lotes

Dada a grande variabilidade das áreas dos lotes, $\left(Z_{1}\right.$ - média: $391 \pm 492 \mathrm{~m}^{2} ; Z_{2}$ - média: $244 \pm 355 \mathrm{~m}^{2} ; Z_{3}-244 \pm 530 \mathrm{~m}^{2} ; Z_{B}$ - média: $5059 \pm 6.622 \mathrm{~m}^{2}$ ), e o elevado índice de impermeabilização dos mesmos, o cálculo do volume total dos reservatórios foi realizado a partir do total da área impermeável nos lotes, para cada um dos dois grupos de zonas: zona residencial-comercial-serviços $\left(Z_{1}, Z_{2}, Z_{3}\right)$ e zona industrial-recreação $\left(Z_{6}, Z_{8}\right)$.

As áreas de abrangência deste dois grupos de zonas são praticamente coincidentes com as dos dois domínios geológicos: os terrenos terciários e quaternários, respectivamente. 
Deve-se observar, porém que a zona residencial-comercial-serviços possui $12 \%$ de sua área no domínio quaternário. No entanto, para facilidade dos cálculos será assumido que as áreas das zonas de ocupação são coincidentes com as dos respectivos terrenos geológicos.

7.3.3 Capacidade dos reservatórios de retenção do escoamento na bacia

Pela expressão para o dimensionamento dos reservatórios do COE, verifica-se que as variações dos volumes dependem da área impermeável de cada terreno (S-Sp), já que os demais parâmetros săo constantes.

Admitindo-se a construção dos micro-reservatórios em todos os domicílios, o volume total da precipitação que poderia ser por eles retido, em toda área da bacia, corresponderia à somatória dos volumes de todos os reservatórios.

Ressaita-se que, embora pela lei, os micro-reservatórios devam possuir condições para absorção no solo, para simplificação nos cálculos os mesmos serão aqui tratados como estanques.

A distribuição das áreas, segundo o tipo de ocupação, foi utilizada no cálculo do volumes potencialmente retido nas duas regiöes principais (Quadro 1): residencial-comercialserviços e industrial-recreação.

$\mathrm{Na}$ área abrangida pelas zonas $Z_{1}, Z_{2}$ e $Z_{3}$ (residencial-comercial-serviços), o termo (S$S p)$ é de $4.099 .782 \mathrm{~m}^{2}\left(57 \%\right.$ desta regiäo), e na área abrangida pelas zonas $Z_{6}$ e $Z_{8}$ (industrial-recreação, $962.960 \mathrm{~m}^{2},(40 \%$ da região). Substituindo-se estes valores naquela expressão encontrou-se os volumes apresentados na Tabela 21.

\begin{tabular}{c|c|c|c} 
Zona de Ocupação & \multicolumn{2}{|c|}{$\begin{array}{c}\text { Volume dos } \\
\text { Reservatórios }\end{array}$} & $\begin{array}{c}\text { \% em relação à } \\
\text { precipitação total } \\
(\mathbf{1 8 1 8} \mathbf{~ m m})\end{array}$ \\
\hline $\begin{array}{c}\mathrm{Z}_{1}+\mathrm{Z}_{2}+\mathrm{Z}_{3}- \\
\left(\mathrm{m}^{3}\right)\end{array}$ & $\mathbf{m m}$ & \\
$\begin{array}{c}\text { Residencial-Comercial-Serviços } \\
Z_{8}+Z_{8}\end{array}$ & 36.898 & 3,8 & 6,4 \\
\hline $\begin{array}{c}\text { Industrial-recreação } \\
\text { Total }\end{array}$ & 8.667 & 0,9 & 1,5 \\
\hline
\end{tabular}

TABELA 21 - Capacidade dos micro-reservatórios 


\subsubsection{Resultados}

A Tabela 22 aparesenta os resultados da precipitação excedente $\left(h_{\text {exc }}\right)$, infiltração $(l) e$ coeficiente de escoamento superficial direto (C) para a chuva crítica apresentada na expressão do dimensionamento do reservatório $(P=60 \mathrm{~mm} ; t=1 \mathrm{~h} ; \mathrm{Tr}=10$ anos), tendo sido consideradas duas condições de ocupação.

\begin{tabular}{|c|c|c|c|c|}
\hline \multirow{3}{*}{$\begin{array}{l}\text { PARÂMETROS } \\
\text { HIDROLÓGICOS }\end{array}$} & \multicolumn{4}{|c|}{$P=60 \mathrm{~mm} ; t=1 \mathrm{~h} ; \mathrm{Tr}=10$ anos } \\
\hline & \multicolumn{2}{|c|}{$\begin{array}{l}\text { SUMARE } \\
A=4,5 \mathrm{~km}^{2}\end{array}$} & \multicolumn{2}{|c|}{$\begin{array}{l}\text { POMPEIA } \\
A=5,1 \mathrm{~km}^{2}\end{array}$} \\
\hline & $\begin{array}{c}\text { ocupação } \\
\text { natural }\end{array}$ & $\begin{array}{c}\text { ocupação } \\
\text { urbana }\end{array}$ & $\begin{array}{c}\text { ocupação } \\
\text { natural }\end{array}$ & $\begin{array}{c}\text { ocupação } \\
\text { urbana }\end{array}$ \\
\hline$h_{\text {exc }}(m m)$ & 38,44 & 54,18 & 38,44 & 54,18 \\
\hline I (mm) & 21,56 & 5,82 & 21,56 & 5,82 \\
\hline C & 0,64 & 0,90 & 0,64 & 0,90 \\
\hline
\end{tabular}

$h_{\text {exc }}=$ precipitação excedente; $1=$ infiltração; $\quad C=$ coef. escoamento superficial; $\mathrm{Tr}=$ tempo de retorno

TABELA 22 - Parâmetros hidrológicos calculados pelo método de Horton

Ressalta-se, que, por este método (equação de Horton) não são contabilizadas as perdas iniciais devidas à intercepção e retenção nas depressōes, o que provocaria uma pequena redução no índice do escoamento superficial.

Os resultados não apresentaram variação, entre as sub-bacias, devido à semeihança na forma e dimensão das mesmas.

O volume da infiltração que ocorreria em toda a área das sub-bacias $\left(9,6 \mathrm{~km}^{2}\right)$, sob condições naturais (pré-ocupação), seria de $206.976 \mathrm{~m}^{3}$ ou 21,56 mm, conforme apresentado na Tabela 22. Considerando somente a área total ocupada pelos lotes, que é de $7,24 \mathrm{~km}^{2}$ (Quadro 1), o volume infiltrado nas duas sub-bacias seria de $156.270 \mathrm{~m}^{3}$ ou $16,28 \mathrm{~mm}$.

$\mathrm{Na}$ condição urbana, a precipitação excedente é $30 \%$ maior que na condição naturai, e a infiltração é $27 \%$ menor.

Os parâmetros dos hidrogramas obtidos pelo método de Santa Bárbara nas duas condições de ocupação são apresentados na Tabela 23. 


\begin{tabular}{|c|c|c|c|c|}
\hline \multirow{3}{*}{$\begin{array}{l}\text { PARÂMETROS } \\
\text { HIDROLÓGICOS }\end{array}$} & \multicolumn{4}{|c|}{$P=60 \mathrm{~mm} ; t=1 \mathrm{~h} ; \mathrm{Tr}=10$ anos } \\
\hline & \multicolumn{2}{|c|}{$\begin{array}{l}\text { SUMARE } \\
A=4,5 \mathrm{~km}^{2}\end{array}$} & \multicolumn{2}{|c|}{$\begin{array}{l}\text { POMPEIA } \\
A=5,1 \mathrm{~km}^{2}\end{array}$} \\
\hline & $\begin{array}{c}\text { ocupação } \\
\text { natural }\end{array}$ & $\begin{array}{c}\text { ocupação } \\
\text { unbana }\end{array}$ & $\begin{array}{c}\text { ocupação } \\
\text { natural }\end{array}$ & $\begin{array}{c}\text { Ocupação } \\
\text { urbana }\end{array}$ \\
\hline $\begin{array}{c}\text { Instante de ocorrência do } \\
\text { pico (h) }\end{array}$ & 1,12 & 0,96 & 1,12 & 0,96 \\
\hline $\begin{array}{l}\text { pico da vazão máxima } \\
\qquad\left(\mathrm{m}^{3} / \mathrm{s}\right)\end{array}$ & 28,8 & 51,0 & 32,7 & 57,8 \\
\hline Volume hidrograma $\left(\mathrm{Mm}^{3}\right)$ & 0,17 & 0,24 & 0,20 & 0,28 \\
\hline
\end{tabular}

TABELA 23 - Parâmetros hidrológicos obtidos pelo método de Santa Bárbara

\subsubsection{Análise dos Resultados}

A parcela da precipitação excedente que idealmente deveria ser amortizada foi considerada aquela correspondente à infiltração, na condição natural, tendo-se obtido, pela equação de Horton, considerando-se a infiltração em toda a área das sub-bacias, um total de $206.976 \mathrm{~m}^{3}(21,56 \mathrm{~mm})$, Tabela 22, e a infiltração apenas na área correspondente aos lotes, um total de $156.270 \mathrm{~m}^{3}(16,27 \mathrm{~mm})$.

Na condição de ocupação atual é garantida uma pequena parcela da precipitação, $56.000 \mathrm{~m}^{3}(5,82 \mathrm{~mm})$ que se infiltra nas áreas nåo impermeabilizadas (Tabela 22).

No cálculo do volume dos reservatórios (item 7.3.3), foi obtido um volume máximo de $46.565 \mathrm{~m}^{3}(4,7 \mathrm{~mm})$, que poderia ser retido, admitindo-se condições estanques dos reservatórios.

Nas condições acima relacionadas o volume ideal a ser amortecido, correspondente à infiltração nas condições de pré-ocupação, pode seguir a dois critérios: (a) considerar o volume que se infiltraria em toda a área das sub-bacias $\left(9,6 \mathrm{~km}^{2}\right)$, (b) considerar o volume que se infiltraria somente nas áreas ocupadas pelos lotes $\left(7,24 \mathrm{~km}^{2}\right)$.

A partir do volume que seria infiltrado em toda área, o volume que deveria ser amortecido pelos reservatórios, seria reduzido a $150.976 \mathrm{~m}^{3}(15,7 \mathrm{~mm})$, descontando-se a infiltração potencial total $\left(206.976 \mathrm{~m}^{3}\right.$ ou $\left.21,56 \mathrm{~mm}\right)$, da infiltração ocorrida nas áreas não impermeabilizadas atuais $\left(56.000 \mathrm{~m}^{3}\right.$ ou $5,82 \mathrm{~mm}$ ). Nesta condição, o volume máximo de amortecimento pelos reservatórios $\left(45.000 \mathrm{~m}^{3}\right)$ seria de aproximadamente $30 \%$ do ideal $\left(150.976 \mathrm{~m}^{3}\right)$.

A partir do volume que seria infiltrado somente nas áreas ocupadas pelos lotes, 0 volume que deveria ser amortecido pelos reservatórios, seria reduzido a $100.270 \mathrm{~m}^{3}$ ou 10,44 $\mathrm{mm}\left(156.270 \mathrm{~m}^{3}\right.$ ou $16,23 \mathrm{~mm}$ menos $56.000 \mathrm{~m}^{3}$, ou $\left.5,82 \mathrm{~mm}\right)$. Nesta condição o volume 
máximo de amortecimento pelos reservatórios $\left(45.000 \mathrm{~m}^{3}\right)$ corresponderia a aproximadamente $45 \%$ do volume ideal $\left(100.270 \mathrm{~m}^{3}\right)$.

O tempo de ocorrência de pico não apresentou variação significativa, em relação às duas condições de ocupação, devido à elevada declividade do terreno, da ordem de 0,05 nos seus $2 / 3$ montantes. Porém, a vazão de pico é cerca de $43 \%$ maior na condição natural, e o volume do escoamento total $30 \%$ maior.

\section{DISCUSSÃO}

As imprecisões de aplicação do método no cálculo da recarga são admitidas como devidas, principalmente, aos seguintes fatores:

a) acentuada variação textural e das espessuras dos estratos do solo, lateral e verticaimente, não permitindo a obtenção dos valores reais da porosidade efetiva do aqüifero.

b) subestimação da recarga direta, quando considerado no cálculo da área do aqüifero, apenas as áreas livres da impermeabilização.

c) amostragem de lotes para extrapolaçăo dos resultados estimativos das áreas permeáveis e impermeáveis.

d) subestimação da recarga direta devido ao intervalo de medição mensal adotado: pequenos incrementos certamente ocorreram, sem que os mesmos não tenham sido registrados. A soma de todas as variações positivas que ocorreram no periodo de 44 dias (22/set/95 a $03 /$ nov/95), é superior à que seria obtida apenas pelas duas leituras mensais (22/set e 03/nov). Espaçamentos de tempo menores forneceriam resultados mais precisos, entretanto, seriam necessários equipamentos de medição mais sofisticados para monitoramento contínua ou até sistema de telemetria.

e) superestimação da recarga direta devido a eventuais acréscimos na espessura saturada, a partir de outras fontes de recarga (indireta), tais como as perdas de esgotos, vazamentos pela rede de águas pluviais, vazamentos pela rede de distribuiçăo, escoamentos das áreas indiretamente conectadas (IC) e irrigação dos jardins onde se localizam os poços.

Analisando-se em conjunto, observa-se que existem fatores que determinam tanto a subestimação (itens $b$ e d) quanto a superestimação $(e)$ da recarga direta, podendo existir uma compensação entre eles.

A recarga especifica estimada no campus da Cidade Universitária (IRITANI, 1993), cuja área permeável prevalece sobre a impermeável, o valor médio da recarga foi estimada em $0,24 \mathrm{Mm}^{3} / \mathrm{km}^{2} / a n o$, o que representa quatro vezes o valor médio encontrado na bacia urbana em estudo, que foi de $0,06 \mathrm{Mm}^{3} / \mathrm{km}^{2} / a n o$. Note-se que esta representa $25 \%$ da recarga especifica direta, encontrada para a bacia sob condições naturais $\mathbf{( 0 , 2 5}$ 
$\mathrm{Mm}^{3} / \mathrm{km}^{2} / \mathrm{ano}$ ). Apesar desta constatação, este vaior é uma aproximação e não deve ser tomado como um valor fixo.

A considerável diferença da taxa de recarga especifica, da ordem da ordem de $50 \%$ a mais no terreno quaternário, é explicada pelas condições mais favoráveis à infiltração e acúmulo, tanto do ponto de vista de ocupação ( $40 \%$ de área livre da impermeabilização) como pela menor declividade do terreno e do gradiente hidraulico.

Quanto à recarga indireta, para obtenção de uma maior precisão nos volumes infiltrados a partir dos vazamentos da rede de distribuição, seria necessária uma investigação bastante detalhada dos locais (nas adutoras e ligações domésticas) e das formas de ocorrência destes vazamentos. Estas águas podem ter vários destinos, porém a compartimentação dos seus volumes é ainda uma incógnita. Dependetemente da ocorrência individual, podem ser admitidos vários encaminhamentos destes volumes: (a) infiltrar-se totalmente por um lango periodo de tempo (vazamentos năo visíveis); (b) uma parte pode infiltrar no solo e outra parte, escoar pela superfície, devido à pressurizaçăo e a partir dai, entrar nas galerias de águas pluviais, ou infiltrar no solo, se houver condições apropropriadas. Assim sendo, admitir que todo volume de perdas físicas estimados pela SABESP torna-se recarga seria uma suposição irreal. Entretanto estudos mais detalhados poderão elucidar esta questão.

O volume total de perdas por vazamentos encontrado foi de $5,11 \mathrm{Mm}^{3}$, e, admitindo-se que toda perda física torna-se recarga, isto representaria cerca de 8 vezes a recarga direta total $\left(0,64 \mathrm{Mm}^{3}\right)$. Pelos resultados de recarga total obtidos $(600 \mathrm{~mm})$, não se verifica, ainda, a necessidade de promover-se a infiltração da água da precipitação para fins de reposição no aqüifero, pensando-se na sua utilização atual.

Para que os volumes dos hidrogramas das áreas dos lotes possam retornar ao observado nas condições de pré-ocupação, deveria haver uma retenção de $100.270 \mathrm{~m}^{3}$ ou $10,44 \mathrm{~mm}$. Cerca de $45 \%\left(45.565 \mathrm{~m}^{3}\right)$ deste volume pode ser armazenado nos reservatórios previstos na lei municipal. Deve-se ressaltar, entretanto, que este volume obtido, é um pouco abaixo do que se deveria obter, pois não foi levado em consideração o volume que pode ser infiltrado durante o evento.

Se fosse considerado o amortecimento do pico do hidrograma gerado para toda a bacia, os reservatórios amorteceriam apenas $30 \%$ ou um pouco mais (pelo mesmo motivo anteriormente citado) do volume necessário estimado em $150.976 \mathrm{~m}^{3}(15,7 \mathrm{~mm})$.

Embora os indices de reservação obtidos pela construção dos reservatórios não sejam suficientes para retratar as condições de pré-ocupação, eles são significativos, principalmente se considerados em conjunto com outras medidas (convencionais) de atenuação do escoamento que poderiam ser adotadas. 
Para efeito de atenuação do pico do escoamento superficial visando dimiuir os riscos de enchentes, medidas tais como as previstas na lei municipal são imprescindíveis. Entretanto, a lei é bastante ampla, não sendo explícitas: as características construtivas do reservatório, a disposição do reservatório no lote, nem quanto à forma de despejo na rede pública de águas pluviais (se por gravidade ou por bombeamento). Estas questões são pertinentes para um melhor desempenho e exeqüibilidade dos reservatórios, necessitando ser investigadas, a exemplo de estudos desenvolvidos por GENZ E TUCCI (1995), na cidade de Porto Alegre. Estes autores concluíram que, utilizando-se micro-reservatórios domiciliares de retenção, é possível a redução da vazão de pico ao nível de pré-ocupação para um lote $100 \%$ impermeável.

Embora se reconheça que a criação desta lei marca o início da tomada efetiva de ações preventivas contra as inundações no município de São Paulo, a mesma apresenta uma grave deficiência, que é a sua năo retroatividade, ou seja, atinge somente os terrenos, cuja ocupação se deu a partir da data de sua regulamentação (1992). Fica desobrigado de cumprila, a quase totalidade do município, dificultando uma análise prática da eficiência destas medidas. Além disso, sabe-se que as exigências prescritas na lei, na maioria dos casos, não são cumpridas, uma vez que a fiscalização é bastante precária.

Diversos modelos de reservatórios são propostos na literatura, sendo que, a utilização dos modelos que possuem as múltiplas funções - de retardamento e infiltração, como o modelo previsto na lei municipal, devem se revistos com muita cautela. No caso do município de São Paulo, sua construção deveria evitar:

- as áreas no domínio terciário, cujos níveis freáticos possuem menos de $4 \mathrm{~m}$ de profundidade, pois estes estão normalmente associados a aqüiferos suspensos;

- e os terrenos da várzea, onde os níveis freáticos são igualmente elevados.

Nas áreas mais acidentadas do terreno terciário, eventuais elevações do nível freático devidas à promoção da infiltração pelos reservatórios, podem gerar conseqüências indesejáveis, tais como o afogamento de garagens, de obras de infra-estrutura, e deslizamentos de taludes. Deve-se ressaltar que, ainda hoje, problemas de infiltração de água nas estruturas é um prolema comum que atinge determinadas áreas da bacia.

Verifica-se que há necessidade de reformulação da lei municipal no sentido de tornar mais eficaz o sistema de reservatórios domiciliares. Estudos específicos, devem adequar modelos de reservação à compartimentação hidrogeológica dos terrenos sedimentares e cristalinos para todo o município. Os aspectos mais importantes a serem contemplados nesta reformulação são:

- redimensionamento dos reservatórios; 
- definição clara de um ou mais protótipos de reservatórios, de acordo com as caracteristicas de permeabilidade do solo e com a profundidade da superfície freática. Os protótipos devem considerar também as condições de manutenção;

- definição clara do local onde deverá ser instalado o reservatório no lote;

- viabilidade técnica e econômica para fiscalização e manutenção dos dispositivos hidráulicos;

- reavaliação da responsabilidade do custeio da construção dos dispositivos;

- avaliação das bacias onde seria conveniente a implantação dos sistemas de reservatórios domiciliares no município de São Paulo e da sua efetivação em conjunto com outros sistemas de retardamento e absorção do escoamento superficial;

- ampliação da obediência à lei para todos os lotes ocupados, principalmente em áreas densamente urbanizadas, independentemente da data de sua ocupação;

- estudo das condições sanitárias para reutilização adequada das águas coletadas em reservatórios domiciliares;

- trabaiho de conscientização da população para aceitação das medidas necessárias;

- projetos para ampliação de áreas não impermeáveis (áreas verdes) em substituição às impermeabilizadas em determinadas regiőes do município (áreas verdes), e

- avaliação do custo-benefício mediante a implantação dos reservatórios.

Sem dúvida alguma a criação da Lei municipal $n^{\circ} 11.228 / 92$, constituiu numa iniciativa relevante para o saneamento dos problemas de enchentes no município de Săo Paulo, a partir de medidas estruturais de menor porte, e não convencionais. Entretanto existe ainda uma grande distância entre a criação desta lei e a observação prática dos seus resultados. 


\section{CONCLUSÕES}

- O estudo da recarga direta restrito apenas o aqüifero freático foi importante para mostrar os processos iniciais da recarga aquifera, evitando-se, assim, a influência de rebaixamentos devidos a bombeamentos por poços profundos. Como de fato, não foi verificado nenhuma alteração anormal dos niveis d'água monitorados.

- Foi demonstrada uma considerável redução da infiltração natural, na razão de $75 \%$, para as condições de ocupação da área, tendo sido registrada uma recarga de apenas 67 $\mathrm{mm} / \mathrm{ano}$ dos $1818 \mathrm{~mm}$ precipitados.

- A influência da impermeabilização sobre a recarga foi observada por meio dos resultados da recarga especifica, tendo sido obtido um valor duas vezes maior $\left(0,1 \mathrm{Mm}^{3} / \mathrm{km}^{2} /\right.$ ano ou $10,2 \mathrm{~mm} / \mathrm{km}^{2} / \mathrm{ano}$ ) na área menos adensada do terreno quaternário, do que na área mais adensada do terreno terciário $\left(0,05 \mathrm{Mm}^{3} / \mathrm{km}^{2} /\right.$ ano ou $\left.5,4 \mathrm{~mm} / \mathrm{km}^{2} / \mathrm{ano}\right)$.

- Os resultados dos incrementos da espessura saturada registrada durante 0 ano de monitoramento, em cada um dos três domínios de profundidade da superfície freática, permitem individualizar duas condições relativas de acumulação e armazenamento:

1) condições mais favoráveis: observadas nos niveis d'água mais profundos do aqülfero freático (variação de $1,93 \pm 0,61 \mathrm{~m} / \mathrm{ano}$ ), e nos aqüiferos quaternários $(1,61 \pm 0,93$ $\mathrm{m} / \mathrm{ano})$.

2) condiçōes menos favoráveis: observadas nos niveis d'água mais rasos - aqülferos suspensos do terciário - $(1,61 \pm 0,93 \mathrm{~m})$, onde os efeitos da infiltração e depleção se processam mais rapidamente.

- A recarga indireta, estimada em $5,11 \mathrm{Mm}^{3} / a n o$ (523 mm/ano), de longe, é a principal responsável pela recarga dos aqülferos, representando $89 \%$ da recarga total. Entretanto este resultado deve ser revisto em estudos específicos, pois foi admitido que todo o vazamento infiltrou-se no subsolo.

- A retenção, por parte dos reservatórios, de $45 \%$ do volume que se infiltraria naturalmente nas áreas dos lotes atualmente impermeabilizados, mostram que os reservatórios domiciliares podem contribuir substancialmente para 0 amortecimento do volume do escoamento superficial.

- A velocidade vertical média obtida, de $0,50 \mathrm{~m} /$ dia revela, boas condições de infiltração no subsolo, entretanto a utilização modelos de reservatórios vazados se esbarram no problema de possiveis sobreelevaçöes das superfícies freáticas e suas conseqüências negativas. 
- Os parâmetros químicos analisados mostraram que o nitrato é o principal responsável pela poluição das águas do aqüifero freático, ocorrendo em quantidades acima dos limites de potabilidade, de forma generalizada.

- Os estudos do escoamento superficial direto mostraram a importância e a necessidade de tabalhos que integrem conhecimentos geológicos e da hidrologia superficial e subterrânea, para uma avaliação mais profunda das medidas de retenção na fonte a serem propostas, visando a atenuação dos picos de enchentes. 


\section{REFERÊNCIAS BIBLIOGRÁFICAS}

ALLISON, G. B. (1988) A review of some of the physical, chemical and isotopic techniques avaliable for estimating groundwater recharge. In: SIMIMERS, I. (ed.) Estimation of natural groundwater recharge. Dordrecht, D. Reidel. p.49-72. (NATO ASI series. Serie C, Mathematical and physical sciences, 222).

ALMEIDA, F.F.M. (1958) O Planalto Paulistano. In: ASSOCIAÇÃO DOS GEÓGRAFOS BRASILEIROS. Cidade de São Paulo: estudos de geografia urbana. São Paulo, Nacional. v.1, p 113 167. (Brasiliana, 14).

ALMEIDA, F.F.M. (1964) Fundamentos geológicos do relevo paulista. Boletim do Instituto Geológico e Geográfico, v.41, p.167-262.

ALMEIDA, F.F.M. (1976) The sistem of continental Rifts bordering the Santos Basin, Brazil. Anais da Academia Brasileira de Ciências, v.48, p.15-26..

BRASIL. INSTITUTO NACIONAL DE METEOROLOGIA (1996) Dados de temperatura diários do Posto Mirante de Santana, SP. Periodo 1994 - 1995. Săo Paulo, INMET (informações do banco de dados).

BRASIL. MINISTERIO DA AGRICULTURA / INSTITUTO NACIONAL DE METEOROLOGIA (1981) Estimativa da evapotranspiração potencial por diferentes métodos e determinação da quantidade de água precipitável para regiōes do Brasil, Boletim Técnico, n. 25, P. 1-88.

CAMARGo, A. P. de (1960) Balanço hídrico do estado de São Paulo (SP). Boletim do Instituto Agronômico, Campinas, n.116, p. 1-24.

CAMPANA, N.A.; TUCCI, C.E.M (1994) Estimativa de área impermeável de macro-bacias urbanas. RBE. Revista Brasileira de Engenharia. Cademo de Recursos Hidricos. Associação Brasileira de Hidrologia e Recursos Hídricos, v. 2, n.2, p 79-94.

CANHOLI, A.P. (1994) O reservatório para controle de cheias da Av. Pacaembu (SP). Engenharia Ambiental, n. 500, p.12 - 19. 
CANHOLI, A.P. (1995) Soluçöes estruturais não convencionais em drenagem urbana. São Paulo, 200 p. (Tese de doutorado). Escola Politécnica - USP.

CLARKE D. (1987) - Microcomputer programs for groundwater studies. Amsterdam, Eisevier. 290 p. (Developments in Water Science 30).

COIMBRA, A.M.; RICCOMINI, C.; MELO, M.S. (1983) A Formação Itaquaquecetuba: evidências de tectonismo no quaternário paulista. In: SIMPÓSIO REGIONAL DE GEOLOGIA, 4, São Paulo, 1972. Atas. SBG/SP, 1983, São Paulo, p. 253-266.

\section{COMMITTEE ON SURFACE-WATER HYDROLOGY OF THE HIDRAULICS DIVISION (1975)}

Task Committee on the effects of urbanization on low flow, total runoff, infiltration, and ground-water recharge. Aspectos of hydrological effects of urbanization. Jounal of the Hidraulics Division, v. 101, n. 5, p.449-68.

COUTINHO, J.M.V. (1972) Petrologia do Pré-cambriano de São Paulo e arredores. Boletim do Instituto de Geociências, v.3, p. 5 - 100.

Cozzolino, V. M. N. (1972) Tipos de sedimentos que constituem a Bacia de São Paulo. Săo Paulo, $116 \mathrm{p}$ (Tese de Doutorado) - Escola Politécnica, Universidade de São Paulo.

CUSTÓDIO, E.; LHAMAS, M.R. (1976) Hidrología Subteránea. Barcelona, Ed. Omega.2v. Barcelona. $1^{\text {a }}$ ed.

EMPRESA METROPOLITANA DE URBANIZAÇÃO (1974) Mapas $\theta$ diagnóstico das bacias de drenagem da capital. São Paulo, EMURB. Escala: 1:10.000.

FREEZE, R.A.; CHERRY, J.A. (1979) - Groundwater. New Jersey, Prentice Hall. 604 p.

FUJITA, S. (1984) Experimental sewer systems for reduction of urban storm runoff. In: INTERNATIONAL CONFERENCE ON URBAN STORM DRAINAGE, 3, 1984. Götborg, 1984. Proceedings. Göterburg, Chatmers University of Technology, v. 3. p 1211-1220.

GALVÃo, P. (1996) Chuva ácida: estudo de caso no Campus USP/SP. São Paulo. 94 p. (Dissertação de Mestrado) - Instituto de Geociências, Universidade de São Paulo.

GARDUÑo, H. (1994) Uso efeciente Del agua: un enfoque multidimensional. In: SEMINARIO INTERNACIONAL SOBRE USO EFICIENTE DEL AGUA, México, 1991. Comissão Nacional del Agua, Instituto Mexicano de Tecnologia del Agua. UNESCO. p.17-19. 
GEE, G.W.; HILLEL, D. (1988) Ground water recharge in arid regions: rewiew an critique of estimation methods. Hydrological Processes, v. 2, p.255-266.

GENZ, F.; TUCCl, E., M. (1995) Controle do escoamento em um lote urbano. RBE. Revista Brasileira de Engenharia. Caderno de Recursos Hídricos. Associação Brasileira de Recursos Hidricos. V. 13 , n. 1, p. 129-152.

GENZ, F.; TUCCI, E., M. (1995) Escoamento em supefícies urbanas. RBE. Revista Brasileira de Engenharia. Cademo de Recursos Hidricos. Associaçăo Brasileira de Recursos Hidricos. v. 13 , n. 1, p. $105-128$.

GENZ, F.; TUCCI, E., M. (1995) Infiltração em superfícies urbanas. RBE. Revista Brasileira de Engenharia. Cademo de Recursos Hidricos. Associação Brasileira de Recursos Hidricos. v. 13 , n. 1, p. $77-103$.

GRINDLEY, J. (1967) The estimation of soil moisture deficits. Mineralogical Magazine, v. 96, n.1137, p.97-108.

GRINDLEY, J. (1969) The calculation of actual evaporation and soil moisture deficits over specified catchments areas. Meteorological Office Bracknell. 3p. (Hydrological Memoire, ก. 38).

HALL, M. J. (1984) Uman Hydrology. London, Elservier Applied Science. 299 p.

HANNINGAN, P.E (1984) Infiltration cut dramatically after pipe repairs. Water/Engenniring ground management. p. 27-28.

HASUI, Y.; CARNEIRO, C. D. RÉ (1980) Origem e evolução da Bacia Sedimentar de São Paulo. IN: MESA REDONDA: ASPECTOS GEOLÓGICOS E GEOTÉCNICOS DA BACIA SEDIMENTAR DE SÃo PAULO, São Paulo, 1980. Publicação Especial. São Paulo, ABGE/SBG, p. 5-13.

HOGLAND, W.; NIEMCZYNOWICZ, J. (1986) The unit superstructure - a new construction to prevent groundwater depletion. In: GORELICK, S. (ed.). Conjunctive water use; undestanding and managing surface water-ground water interactions; INTERNATIONAL ASSOCIATION OF HYDROLOGICAL SCIENCES, Louvain, 1986. IAH-AISH. p. 513 522. (Publication, 156). 
HORTON, R.E (1939) An approach toward a Physical Interpretation of infiltratin capacity. Transactions of the American Geophysical Union, v. 20, p. 1 - 39.

HOWARD, K.W.F.; LLOYD, J.W. (1979) The sensitivity of parameters in the Penman e evaporation equations and direct recharge balance. Joumal of Hydrology, v.41, p. 329344.

INSTITUTO dE PESQUISAS TECNOLÓGICAS DO ESTADO DE SÃo PAULO (1981) - Mapa geológico do Estado de São Paulo: Escala 1:500.000. São Paulo, PRO-MINERRIO/IPT. v. $1,126 \mathrm{p}$.

IRITANI, M.A. (1993) - Potencial hidrogeológico da Cidade Universitária de São Paulo. São Paulo. 97 p. (Dissertação de Mestrado) - Instituto de Geociências, Universidade de São Pauio.

JACOBSEN, P.; HARREMOES, P. (1981) Significance of semi-pervious surfaces in urban hydrology. In: INTERNATIONAL CONFERENCE ON URBAN STORM DRAINAGE, 2 , 1981. Proceedings. Urbana, University of llinois, v.1. p. 424-433.

JOHANSSON, P. (1987) Estimation of groundwater recharge in sandy till with two different methods using groundwater level flutuations, Joumal of Hydrology, v. 90, p. 183-198.

JOHANSSON, P. (1988) Methods for estimation of natural grounwater recharge directly from precipitation - comparative studies in sandy till. In: SIMMERS (ed.). Estimation of natural groundwater recharge. Dordrecht, D. Reidel. p. 239 - 270. (NATO ASI series. Serie C, Mathematical and phusical sciences, 222).

KITCHING, R.; SHEARER, T.R. (1982) Construction and operation of a large undistrubed Iysimeter to measure recharge to the chalk aquifer, England, Joumal of Hydrology, v.58, p. 267-277.

KITCHING. R.; BRIDGE, L. (1974) Lysimeter installations in sandstone at styrrp, nottinghamhire. Journal of Hydrology, v. 23, p. 219 - 232.

KLUTE, A. (1986) Methods of soil analysis. Madison, ASA. 2v.

KNUTSSON, G. (1988) Humid and arid groundwater recharge - a comparative analyses. Estimation of Natural Groundwater Recharge. In: SIMMERS (ed.). Estimation ofnNatural 
groundwater recharge. Dordrecht, D. Reidel. p. 493 - 504. (NATO ASI series. Serie C, Mathematical and Physical Sciences, 222).

LANGSHOLT, E. (1992) A water balance sudy in lateritic terrain. Hydrological Processes, v.6, n. 1, p. $11-27$.

LIBARDI, P.L (1995) Dinâmica da água no solo. São Paulo, ESALQ/USP. Editora Autor. 497 p.

LERNER, D.N. (1986) - Leaking pipes recharge ground water. Ground Water, v. 5, p. 654-662.

LERNER, D.N.; ISSAR, A.S.; SIMMERS, I. (1990) - Ground water recharge - a guide to understanting and estimating natural recharge. Hannover, Veriag Heinz Heise. 345 p. (International Contribuitions to hydrogeology, v. 8).

MAGNI, N.L; MERO, F. (1986) - Precipitações intensas no Estado de São Paulo. Boletim do Centro Tecnológico de Hidráulica DAEE/EPUSP, n. 4, p. 1 - 95.

MASSAD, F. (1980) Características e propriedades geotécnicas de alguns solos da Bacia de Såo Paulo. In: MESA REDONDA: ASPECTOS GEOLOGICOS E GEOTÉCNICOS DA BACIA DE SÃo PAULO, São Paulo, 1980. Publicação Especial. São Paulo, ABGE/SBG p.53- 94 .

MATSCHULLAT, J. (1992) Acid rain: don't just blame the vulcanoes. AGID news, n. 71.

MELLO, M. S.; COIMBRA, A.M.; RICCOMINI, C. (1989) Evolução dos conhecimentos sobre a geologia da a Bacia de São Paulo na década de oitenta. In: WORKSHOP GEOLOGIA DA BACIA DE SÃO PAULO, São Paulo.1989. Coletânea das comunicações. São Paulo, IG-USP/SBG. p. 1-11.

MElo, M. S.; PONÇANO, W. L.; MOOK, W.G.; AZEVEDO, A.E.G. (1987) Datações $C^{14}$ em sedimentos da Grande São Paullo. In: CONGRESSO DA ASSOCIAÇÃO BRASILEIRA DE ESTUDOS DO QUATERNÁRIO, 1, Porto Alegre, 1987. Anais. Porto Alegre, ABEQUA, p. 427 - 436.

MOREL-SEYTOUX, H.J. (1985) Conjunctive use of surface and ground waters. In: ASANO, Takaschid (ed.) Artificial recharge of groundwater. Boston, Buterworth Publishers. p. 3567. 
MORI, R. T. (1992) Oscilações dos niveis freáticos e as repercursões na ocupaçăo urbana. In: SEMINÁRIO PROBLEMAS GEOLÓGICOS E GEOTÉCNICOS NA REGIÃO METROPOLITANA DE SÃo PAULO, São Paulo. 1992. Anais. São Paulo, ABAS/ABGE/SBG, São Paulo. p. 227-235.

MOTTA Jr. J.C.; TUCCI, C.E.M. - Avaliação do efeito da urbanização no escoamento através de modelo hidrológico. Porto Alegre, MEC/UFRS/IPH (Recursos Hidricos, Publ. 6).

MUSIAKE, K.; HERATH, S.; MiNATO-KU; OKAMURA, J. (1994) Efectos de los sistemas de infiltracion de agua pluvial y sub evaluacion. In: SEMINARIO INTERNACIONAL SOBRE USO EFICIENTE DEL AGUA, México, 1991. Comissão Nacional del Agua, Instituto Mexicano de Tecnologia del Agua. UNESCO, p. 287-304.

NIEBER, J.L.; WARNER, G.S. (1991) - Soil pipe contribution to steady subsurface stormflow, Hydrological Processes, v. 5, p. 345-360.

OAKSFORD, E. T. (1995) Artificial recharge: methods, hydraulics, and monitoring. In: ASANO-TAKASHI (ed.) Artificial recharge of groundwater. Boston, Butterwort Publishers. p. $69-127$.

PENMAN, H. L. (1948) Natural evaporation from open water, bare soil and grass. Proceedings Royal Society of London. Serie A, v. 193, p.120-145.

PORTO, R. L. L. (1995) Escoamento superficial direto. In: TUCCI, C.E.M; PORTO, R. LA LAINA; BARROS, M. T. de. Drenagem Umana. Porto Alegre, Editora da Universidade/UFRGS. p. 107 - 165 (Coleção de Recursos Hídricos, v.5).

PORTO, R. L. L.; KAMEL, Z.F. e GIKAS, A.N. (1991) Sistema ABC - Análise de cheias em Bacias Complexas - Manual do Usuário. São Paulo, CTH/EPUSP.

PREFEITURA MUNICIPAL DE SÃo PAULO (1991) Levantamento, por distrito, dos equipamentos sociais na Administração Regional da Lapa. São Paulo, Unidade de Cadastro da AR-LA.

PREFeitura municipal de são paulo / SECRETARIA do planejamento Departamento de Informações (1993) Base de dados para planejamento (BDP): cadernos regionais. São Paulo, Administração Regional da Lapa, Departamento de Informações, $30 \mathrm{p}$. 
REBOUÇAS, A.C. (1992) Condições de uso e proteção das águas subterrâneas. In: SEMINARIO PROBLEMAS GEOLOGICOS E GEOTÉCNICOS NA REGIÃO METROPOLITANA DE SÃO PAULO. São Paulo, 1992. Anais. São Paulo, ABAS/ABGE/SBG-SP. p. 77 - 87 .

RICCOMINI, C.; APPI, C. J.; FREITAS, E. L. de; ARAl, M. (1987) Tectônica e sedimentação no sistema de Rifts Continentais da Serra do mar (bacias de Volta Redonda, Resende, Taubaté e São Paulo). In: SIMPÓSIO REGIONAL DE GEOLOGIA, 1, Rio de Janeiro, 1987. Anais. Rio de Janeiro, SBG-RJ/ES, p. 253-298.

RICCOMINI, C.; COIMBRA, A.M. (1992) Geologia da bacia sedimentar. In: FERREIRA, A. A.; ALONSO, U.R.; LUZ, P.L. Solos da cidade de São Paulo. São Paulo. ABMSIABEF. p. 37-94.

RICOMMINI, C. (1989) O rift continental do sudeste do Brasil, São Paulo. São Paulo, 256 p. (Tese de doutorado) - Instituto de Geociências, Universidade de São Paulo.

RUSHTON, K.; TAWARI, S. C. (1988) Mathematical modelling of a multi-layered alluvial aquifer. India, Institute Enginneers.

RUSHTON, K.R.: TOMLINSON, L.M. (1979) Possible mechanisms for leakage between aquifers and rivers. Joumal of Hydroloy, v. 40, p. 49-65.

RUSHTON, K.R.; WARD, C. (1979) The estimation of ground water recharge. Joumal of Hydrology, v. 41, p. 345-361.

SADOWSKI, G. R. (1984) Estado da arte do tema: geologia estrutural de garndes falhamentos. In: CONGRESSO BRASILEIRO DE GEOLOGIA, 33, Rio de Janeiro, 1984. Anais. SBG, Rio de Janeiro, v.4, p. 1767-1793.

SÃO PAULO (ESTADO) Associação Brasileira de Geologia de Engenharia (1990) - Ensaios de permeabilidade em solos: orientações para sua execução no campo. São Paulo, ABGE/CESP. 8 p.

SÃO PAULO (ESTADO) COMPANHIA DE SANEAMENTO BÁSICO DO ESTADO DE SÃO PAULO (1991) - Planilhas de setorização: Setores Araçá e Vila Romana. São Paulo, SABESP. 
SÃo PAULO (ESTADO) COMPANHIA DE SANEAMENTO BÁSICO DO ESTADO DE SÃO PAULO (1992) Planilhas de setorização: Setores Água Branca e Casa Verde. Săo Paulo, SABESP (Informações).

SÃo PAULO (ESTADO) COMPANHIA DE SANEAMENTO BÁSICO DO ESTADO DE SÃO PAULO (1990) Mapas de subsetorização de abastecimento: Setores Araçá, Água Branca e Mirante. São Paulo, COPLASA/SABESP. Escala 1:5.000.

SÃo PAULO (ESTADO) COMPANHIA DE SANEAMENTO BÁSICO DO ESTADO DE SÃO PAULO (1995) Planilhas de acompanhamento do indice de perdas dos setores Agua Branca, Araçá, Vila Romana, Casa Verde. Controle de perdas da Supervisão de Apoio Técnico MT/Perdas.

SÄO PAULO (ESTADO) COMPANHIA DE SANEAMENTO BÁSICO DO ESTADO DE SÃO PAULO (1994) Diagnóstico Hidrogeológico da Região Metropolitana de São Paulo. Convênio SABESP/CEPAS-IG-USP. Relatório final. $75 \mathrm{p}$.

SÃO PAULO (ESTADO) DEPARTAMENTO DE AGUAS E ENERGIA ELÉTRICA DO ESTADO DE SÃO PAULO (1975). Estudos das águas subterrâneas, Região Administrativa 1. Grande São Paulo. São Paulo, DAEE. 3 v.

SÃo PAULO (ESTADO) DEPARTAMENTO DE ÁGUAS E ENERGIA ELÉTRICA DO ESTADO DE SÃo PAULO (1988) Águas Subterrâneas, Reserva Estratégica. Revista de Águas e Energia Elétrica, v. 5, n. 13, p.14-23.

SÃo PAULO (ESTADO) Departamento de Águas e Energia Elétrica do Estado de São Paulo DAEE (1989) Medidas não estruturais de combate a inundaçōes. Publicaçăo do Departamento de Aguas e Energia Elétrica, v. 5, n. 15, p. 17 - 22.

SÃO PAULO (ESTADO) COMPANHIA DE TECNOLOGIA E SANEAMENTO AMBIENTAL DO ESTADO DE SÃO PAULO (1980) Drenagem Unana: manual de projeto. Såo Paulo, DAEE/CETESB. $2^{\mathrm{a}}$ ed. $468 \mathrm{p}$.

SÃo PAULO (ESTADO) COMPANHIA DE TECNOLOGIA E SANEAMENTO AMBIENTAL DO ESTADO DE SÃO PAULO (1980) Guia de coleta e preservação de amostras de água: preparado pela Divisão de Biblioteca da CETESB. São Paulo, CETESB. $150 \mathrm{p}$. 
SETZER, J. (1976) Atlas da evapotranspiração efetiva no Estado de São Paulo. São Paulo, Secretaria de Obras e do Meio Ambiente/DAEE/CTH. 36 p.

SHARMA, M.L. (ed.) (1989) Groundwater recharge: Proceedings of the Symposium on Groundwater Recharge, Mandurah. Rotterdam, A. A. Balkema. 323 p.

SHEPARD, F. P.; MOORE, D.G. (1954) Sedimentary environments differentiated by coarsefraction studies. AAPG Bulletin, v. 38, n. 8, p. 1792 - 1802.

SHILLING, W. (1982) Cisterns against storms. In: L. FEATHERSTONE, R.E., JAMES, A. (ed.) Urban drainage systems. Southampton, Computational Mechanics Centre. p. 49-60.

SIMMERS, I. (1988) Estimation of natural groundwater recharge. Dordrecht, D. Reidel. 510 p. (NATO ASI serie C, Mathematical and Physical Sciences, 222).

SUGUIO, K. (1980) Síntese dos conhecimentos sobre a sedimentação da Bacia de Săo Paulo. In:MESA REDONDA ASPECTOS GEOLÓGICOS E GEOTÉCNICOS DA BACIA DE SÃO PAULO, São Paulo, 1980. Publicação Especial. São Paulo, ABGE/SBG, p. 25 32.

SUTCLIFFE, J.V.; TUCKER, J.M. (1981) - The water balance of the Betwa basin, India. Hydrological Sciences Bulletin. des Sciences Hydrologiques, v.26, n.2, p149 - 158.

SZIKSAY, M.; KIMMELMANN, A.A.; HYPOLITO, R .; FIGUEIRA, R. M.; SAMESHIMA, H.(1990) Evolution of the chemical compostion of water passing through the unsaturated zone to ground water at an experimental site at the University of São Paulo, Brazil. Jounal of Hydrology, v. 118 (1990), p175-190.

SZIKSZAY, M.; CONSONI, A.J.; YODOTA, H.K.; ARAUJO, J.R.; DUARTE, U. O KANEHISA, M.S. (1987) Estudo preliminar da hidrodinâmica na zona não saturada da Estação Experimental (Cidade Universitária). Revista Águas Subterrâneas, n. 10, p.33-62.

SZIKSZAY, M (1993) Geoquímica das águas. Boletim IG/USP. Série didática, n. 5, 165 p.

TAKIYA, H. (1991) - Aplicação de Métodos quantitativos Espaciais a dados geológicos da Bacia de São Paulo. São Paulo, 109 p. (Dissertação de Mestrado) - Instituto de Geociências, Universidade de São Paulo. 
TARIFA, J.R. (1970) Estudo preliminar das possibilidades agrícolas de Presidente Prudente, segundo o balanço hídrico de Thorntwaite (1948 - 1955). Boletim Geográfico, v. 29, n. 217, p. $34-54$.

THOMSON, J. A. M.; FOSTER, S. S. D. (1986) Effect of urbanization on groundwater of limestone islands: an analysis of the Bermuda case. Institution of Water Engineers and Scientists, $40,527-540$.

THORNTHWAITE, C. W; MATTER, J.R. (1955) The water balance. Centerton, N.J. 104 p.

TUBELIS, A.; NASCIMENTO, F.J.C.; (1987) Meteorologia descritiva - fundamentos e aplicações Brasileiras. São Paulo, Editora Nobel. 374 p.

TUCCI, C. E. M; GENZ, F. (1995) Controle do Impacto da Urbanização. In: TUCCl, C.E.M; PORTO, R. LA LAINA; BARROS, M. T. de. Drenagem Untbana. Porto Alegre, Editora da Universidade/UFRGS. p.277-347.(Coleção ABRH de Recursos Hidricos, v.5)

TUCCl, C. E. M. (1995) Inundações Urbanas. In: TUCCl, C.E.M; PORTO, R. LA LAINA; BARROS, M. T. de. Drenagem Urbana. Porto Alegre, Editora da Universidade/UFRGS. p. 15 - 35 (Coleção ABRH de Recursos Hidricos, v. 5).

TUCCI, E. M., BRAGA, B.P.F; SILVEIRA, A. (1989) Avaliação do impacto da urbanização nas cheias urbanas. RBE Revista Brasileira de Engenharia. Cademo de Recursos Hidricos, v. 7 n. 1. p. $11-101$.

TUCCI, E.M.(1993) Hidrologia: ciência e aplicação. ABRH, Ed. Edusp. 943 p.

URBONAS, B.; STAHRE, P. (1993) Stormwater - best management practices and detention for water quality drainage and CSO Management. Prentice-Hall, Englewood Cliffs. 449 p.

VAN DAM, C.H. ; VAN DE VEN, F. H. M. (1984) Infiltration on the pavment. In: CONFERENCE ON URBAN STORM DRAINAGE. Proceddings. Int. Gothenburg, Sweden, v. 3, p 157 173.

WAANANEN, A. O. (1969) Urban Effects on Water Yield, "effects of Watershed Changes on Streamflow." In: MOORE, W. L.; MORGAN, C.W. (eds.). WATER RESOURSCES SYMPOSIUM, 2, 1969. Proceedings. Austin, University of Texas Press. p 169-182. 
WERNICK, E. (1966) - Análise granulométrica dos sedimetnos da Bacia de São Paulo. Mineração e Metalugia, v. 43, n. 254, p. 63-68.

WILD, J.; RUIZ, J. C. (1987) Lima groundwater modelling revisited. In: NATIONAL HYDROLOGY SYMPOSIUM, Londion, 1987. United Singdom, Bureau Hydrological Society London. p. $14.1-14.12$.

YOSHIMOTO, T.; SUETSUGI, T. (1990) Comprehensive Flood Disaster Prevention Measures in Japan. In: DUISBERG SYMPOSIUM. Hydrological Processes and Water Management in Unban Arøas, IAHS, 1988. p. 175-183. (Publication 198). 


\section{ANEXO 1:}

Perfis litológicos: Poços de Monitoramento 1 a 13, Figuras 1 a 13, respectivamente. 
LEGENDA DOS POÇOS DE MONITORAMENTO

Solo Argiloso

Solo Argilo-Arenoso

Solo Silto-Argiloso

Solo Silto-Arenoso

Solo Areno-Argiloso

Solo Arenoso (grosseiro) 
FIGURA 1 - Perfil Litológico e Construtivo do Poço de Monitoramento

Aterro areno-silto argilos o, plático, com grânulos de quartzo e entulhos

Alúvio argilos o orgânic o, plás tico.

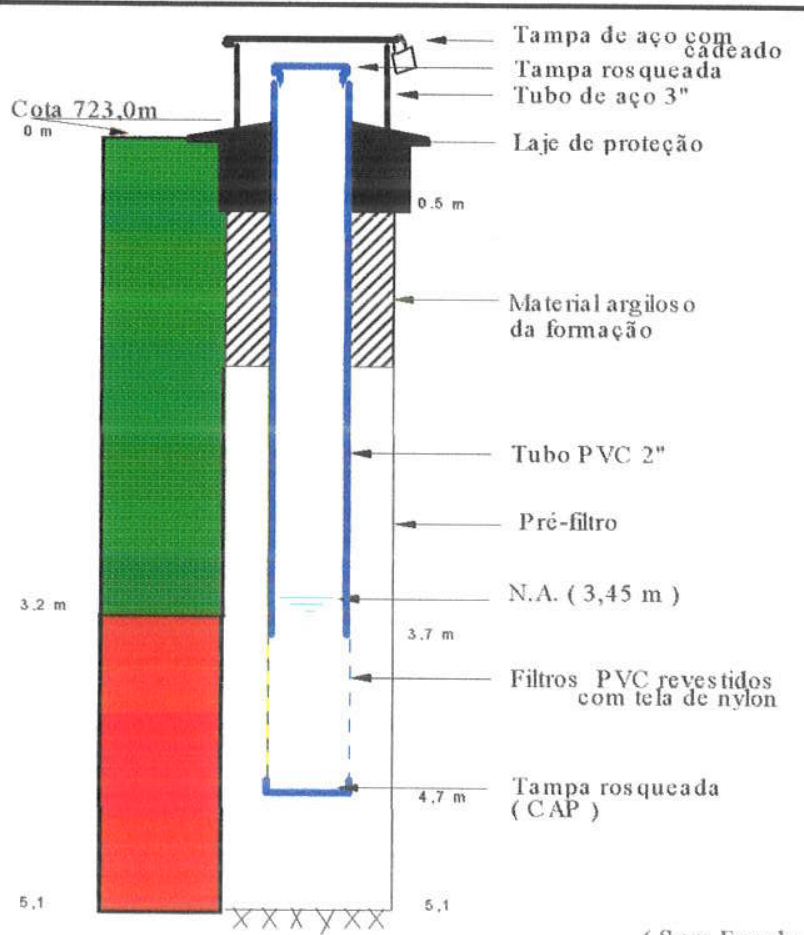

Sem Escala

$\begin{array}{lll}\text { Local: Ponte do Limão, Barra Funda } & \text { Data: } 23 \text { AGO } 94\end{array}$

FIGURA 2 - Perfil Litológico e Construtivo do Poço de Monitoramento 2

Aterro areno-silto-argilos o, contendo "pedaços" de argila e carvão, areia gross $\mathrm{a}, \mathrm{e}, \mathrm{na}$ base, apres enta-s e argilos o de cor negra.

Alúvio argilos o orgânic o, plás tico,

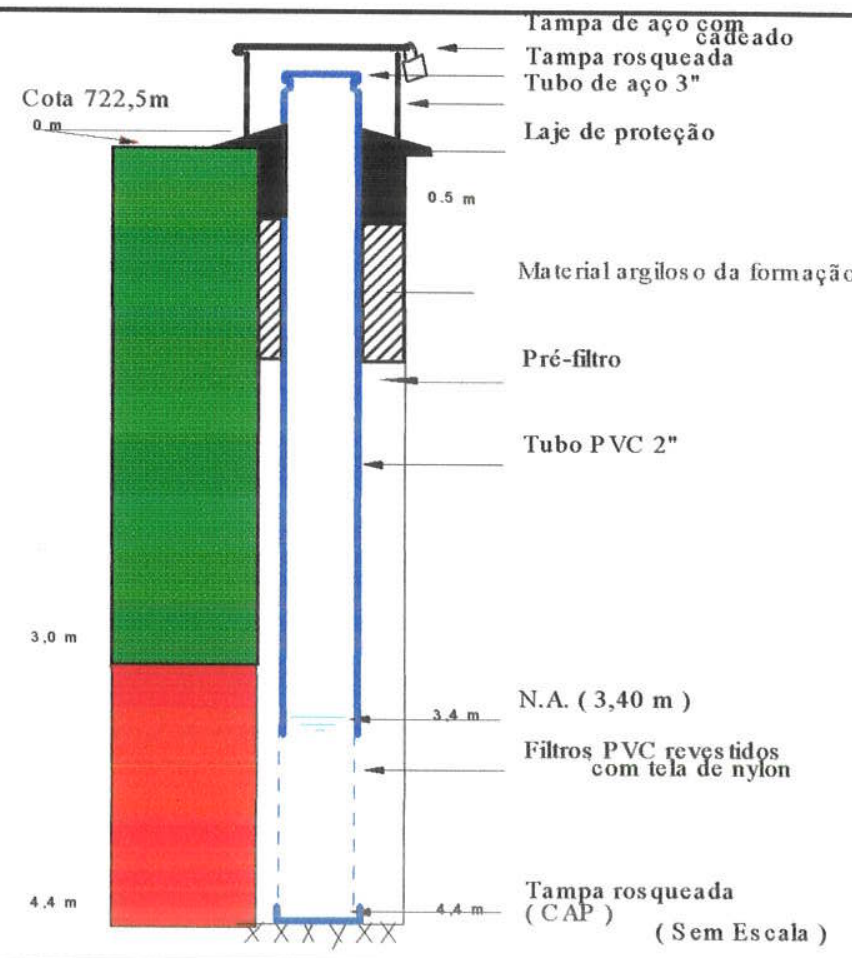


FIGURA 3 - Perfil Litológico e Construtivo do Poço de Monitoramento 3

Aterro silto-argilos o, amarelo ocre.
$\begin{aligned} & \text { Silte argilos o, pouco arenoso, amarelo ocre } \\ & \text { desagregável. (aterro ?) }\end{aligned}$
$\begin{aligned} & \text { Argila arenos a, com micas e felds patos, } \\ & \text { desagregável. (aterro?) }\end{aligned}$
$\begin{aligned} & \text { Argila arenos a, com estratos em variados } \\ & \text { Aeores de areia. }\end{aligned}$
Argila groxa, plás tica.

Local: Prą̧a CondeF. Matarazzo, Água Branca

Data: 25 AGO 94

FIGURA 4 - Perfil Litológico e Construtivo do Poço de Monitoramento 4

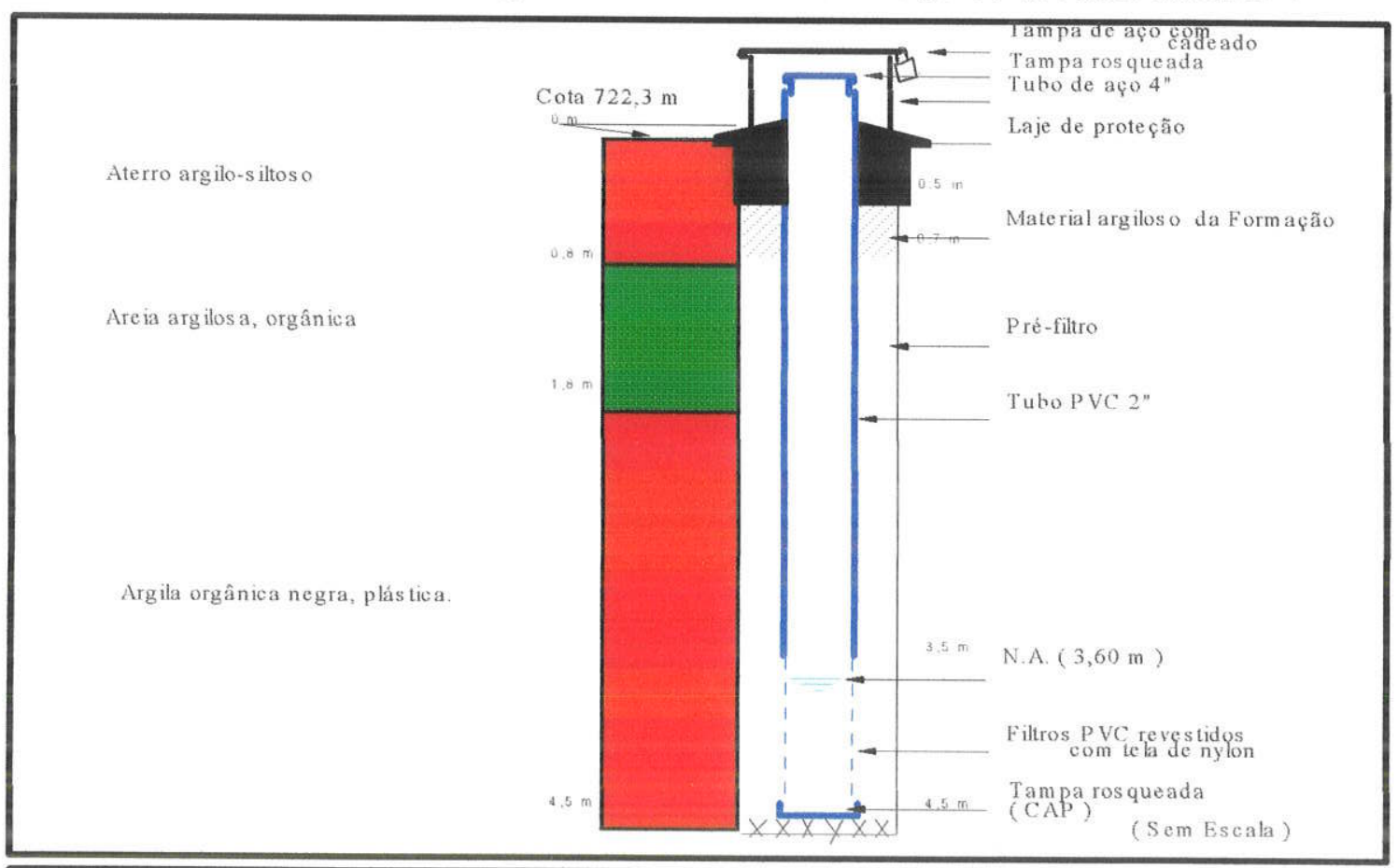


FIGURA 5 - Perfil Litológico e Construtivo do Poço de Monitoramento 5

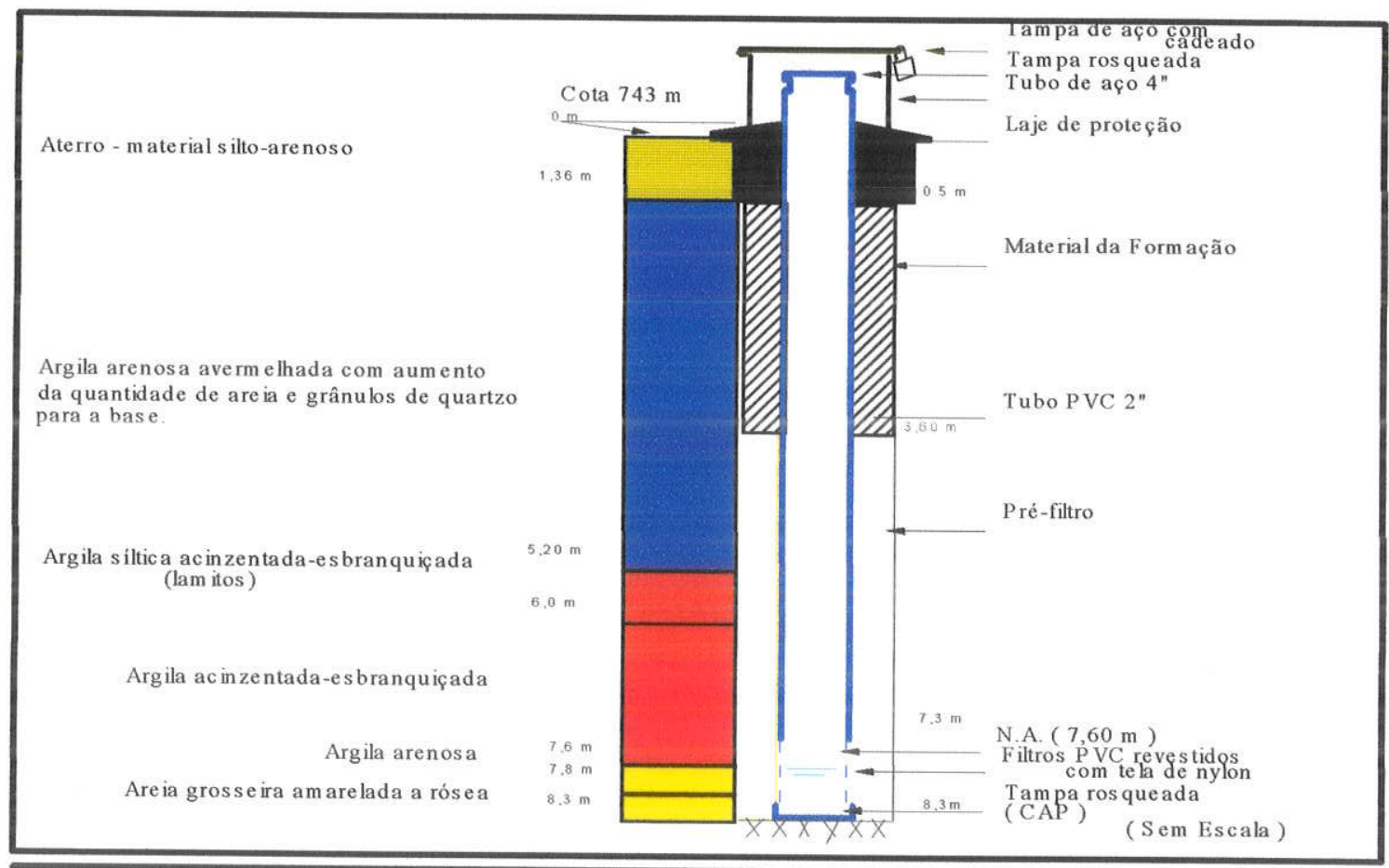

Loc a 1: Praça Cornélia, Vila Romana

D a ta:30 AGO 94

FIGURA 6 - Perfil Litológico e Construtivo do Poço de Monitoramento 6

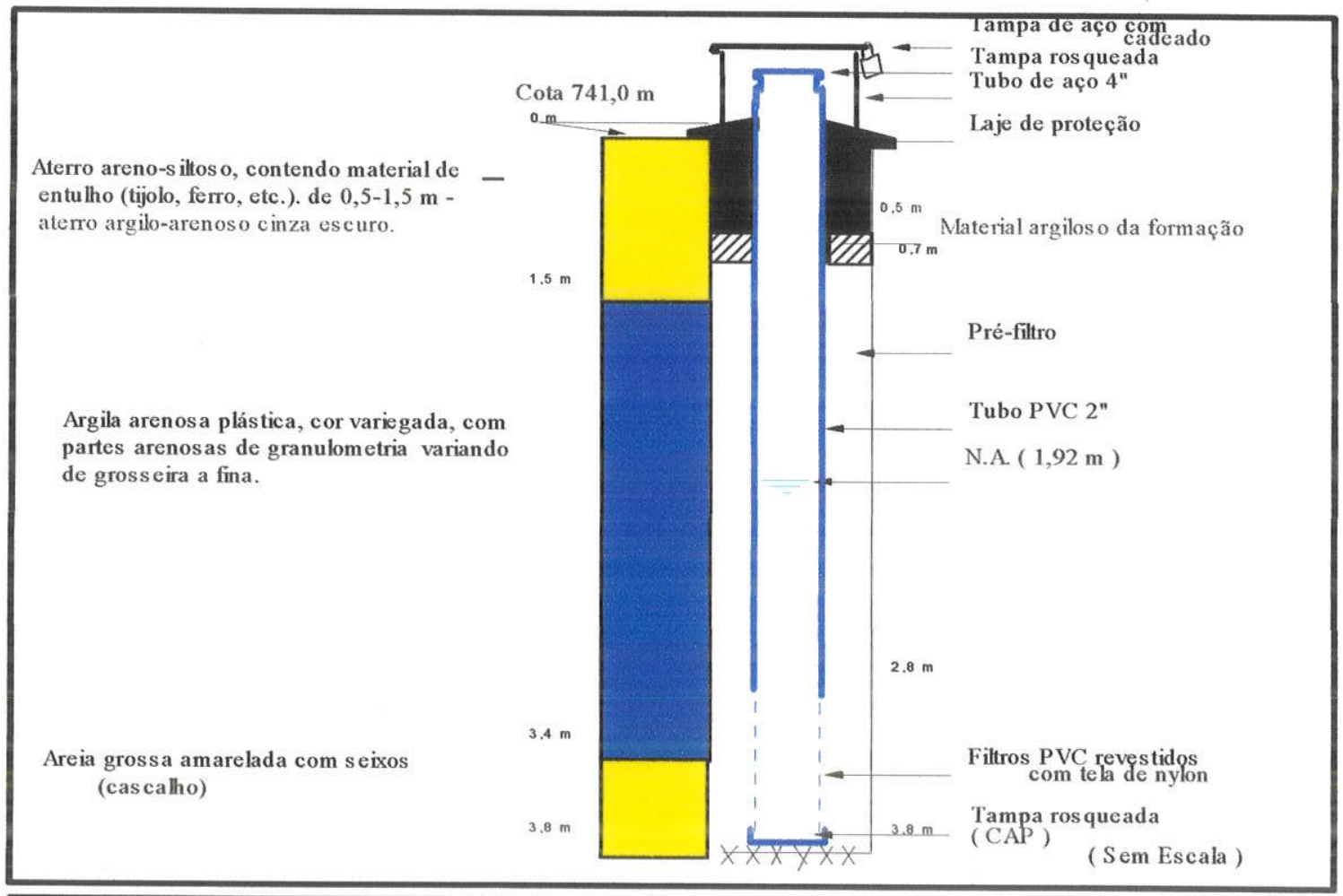

Lo ca 1: Parque da Água Branca, Água Branca

D a ta:31 A G O 94 
FIG URA 7 - Perfil Litológico e Construtivo do Poço de Monitoramento 7

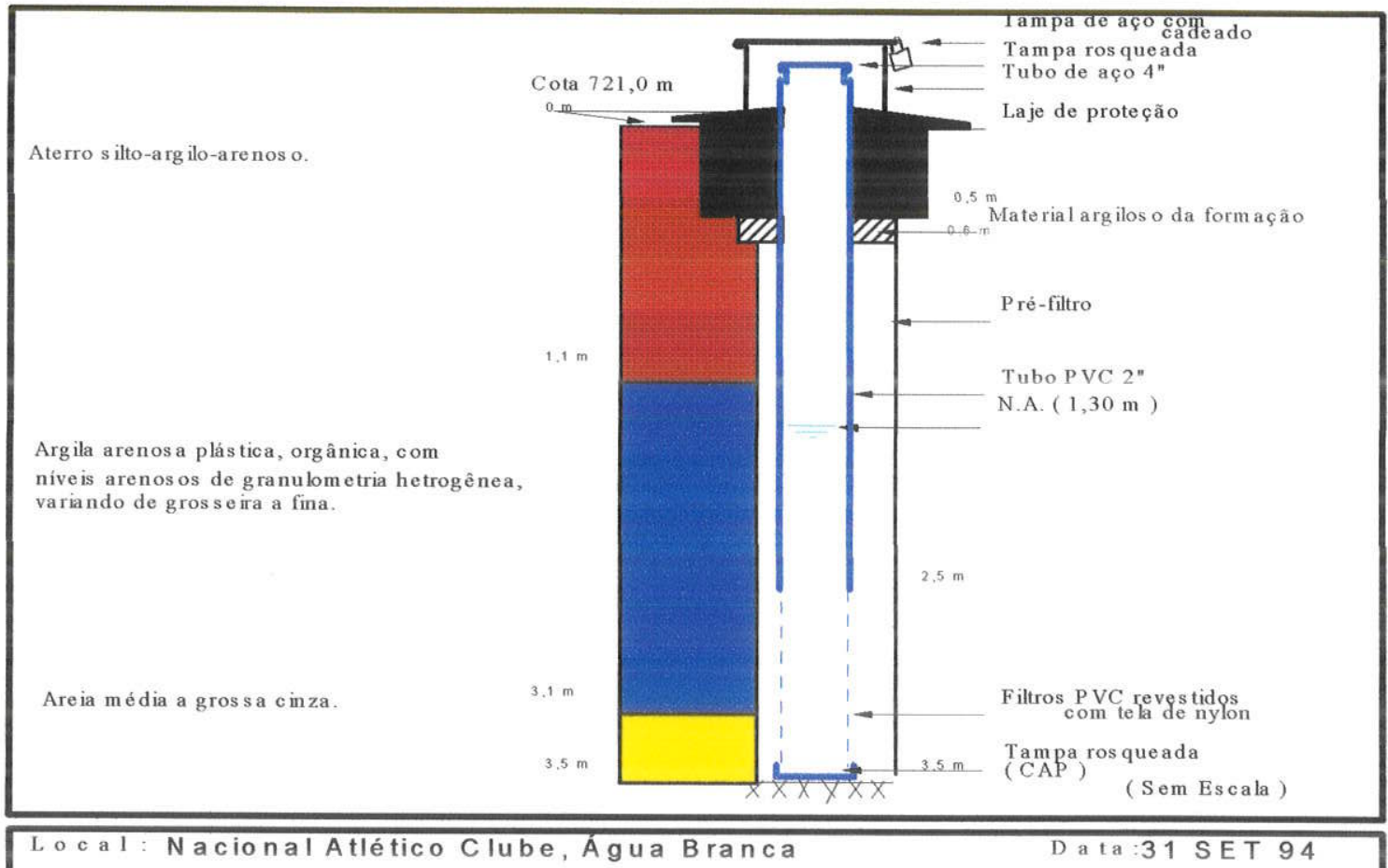

FIGURA 8 - Perfil Litológico e Construtivo do Poço de Monitoramento 8

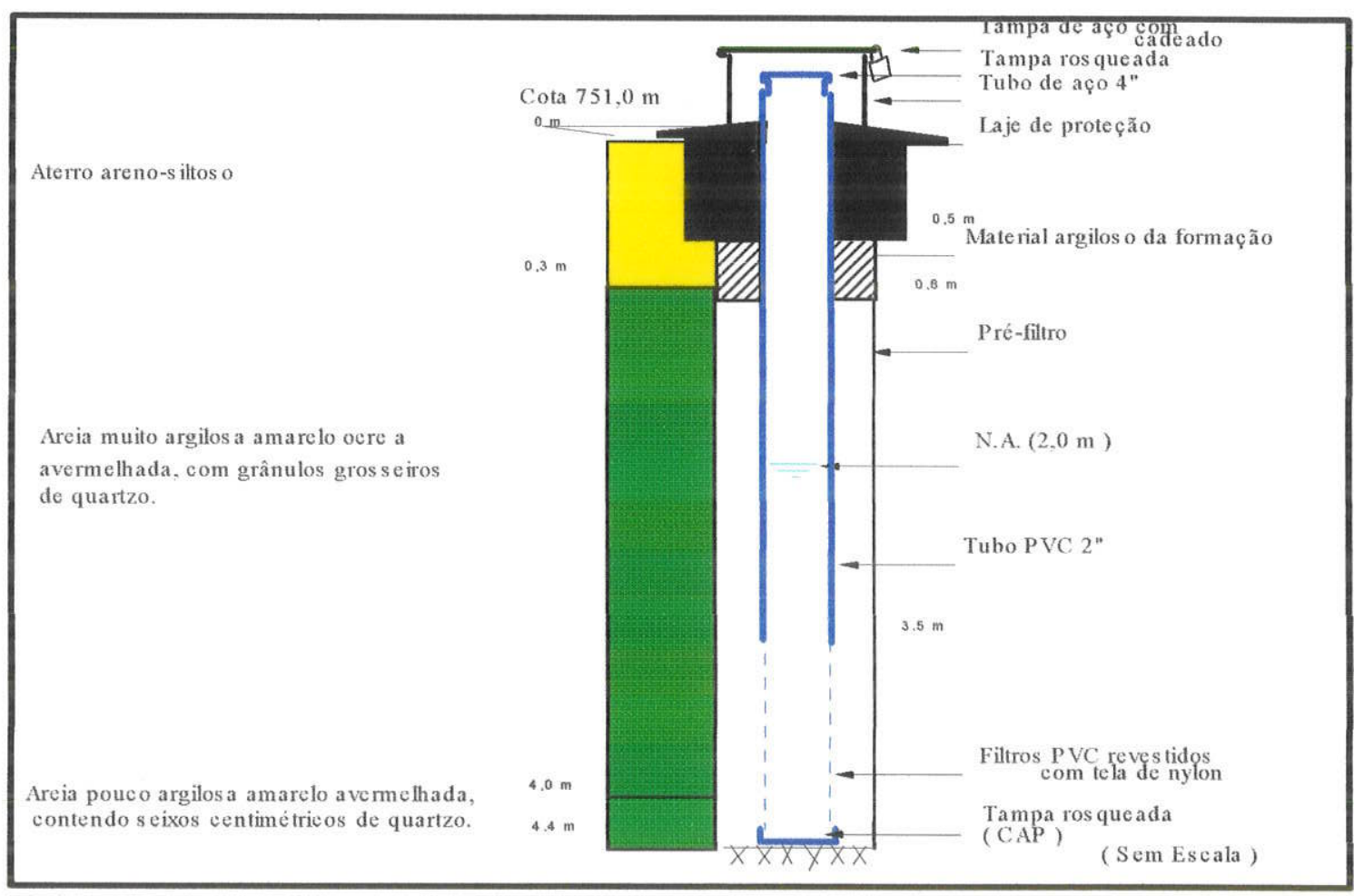

Loc a 1: Pça. Jes uino Bande ira - S ic iliano

D a ta

02 SET 94 
FIGURA 9 - Perfil Litológico e Construtivo do Poço de Monitoramento 9

Aterro sítlic o-argilos o, cor variegada contendo material de entulho.

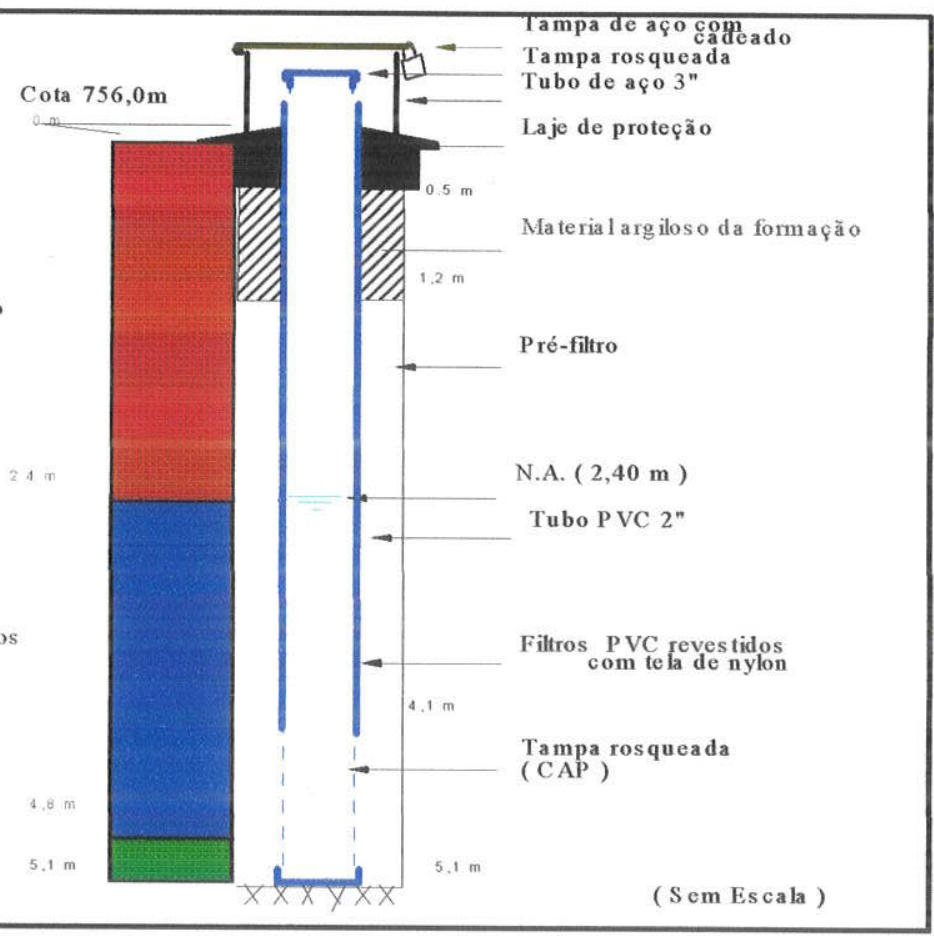

Argila arenos a, cor variega da, com grânu los de quartzo e felds patos, e se ixos subangulosos de arenitos.

Areia Argilosa, cinza esbranquiçada, com ní veis de areia gross a e fragmentos de quartzo e felds pato centimétricos.

( S em Escala )

Loca 1: Praça Irmã os Karma n, Urba nizadora

Data: 05 S E T 94

FIG URA 10 - Perfil Litológico e Construtivo do Pọ̧o de Monitoramento 10

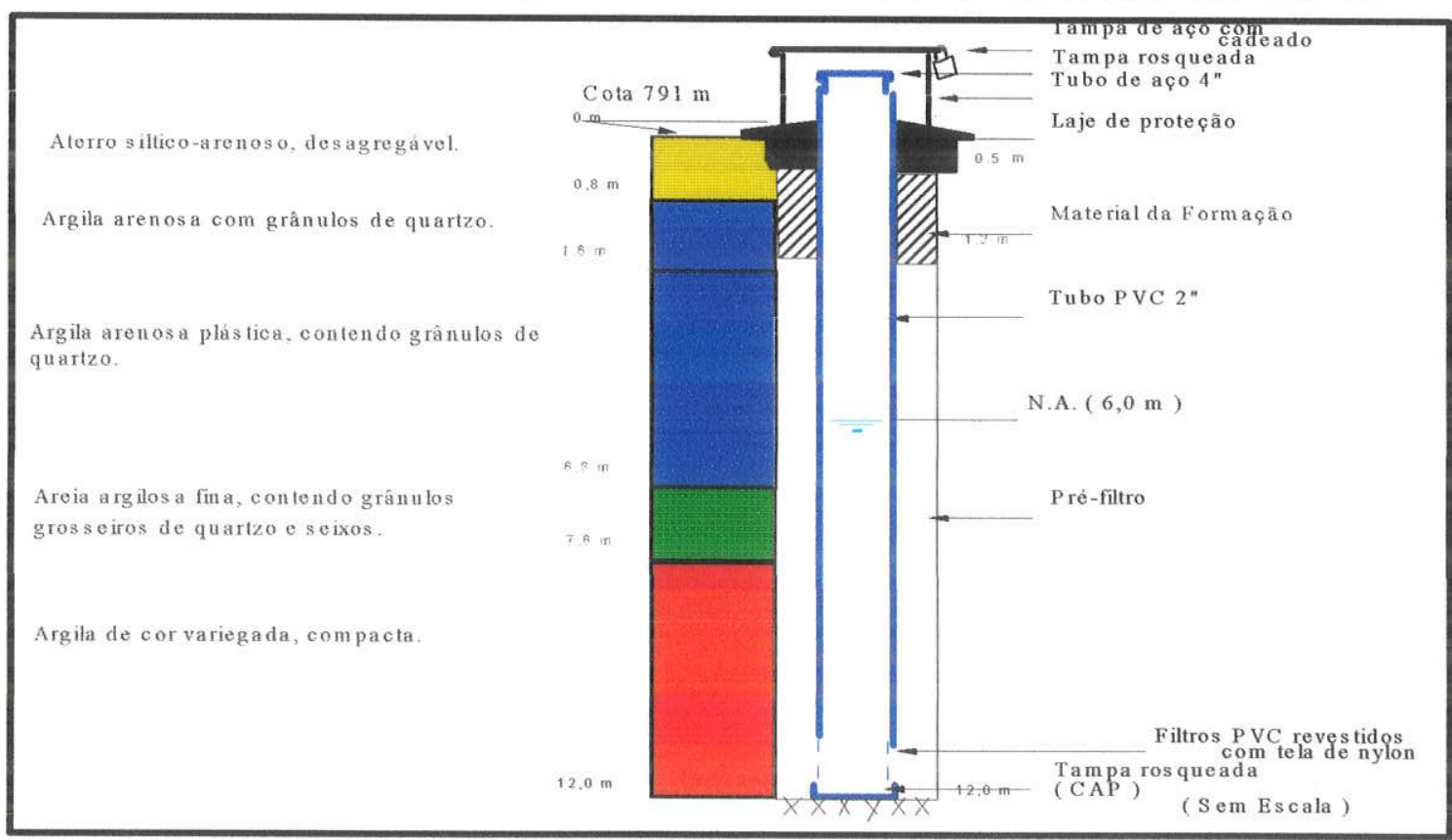


FIGURA 11 - Perfil Litológico e Construtivo do Poço de Monitoramento 11

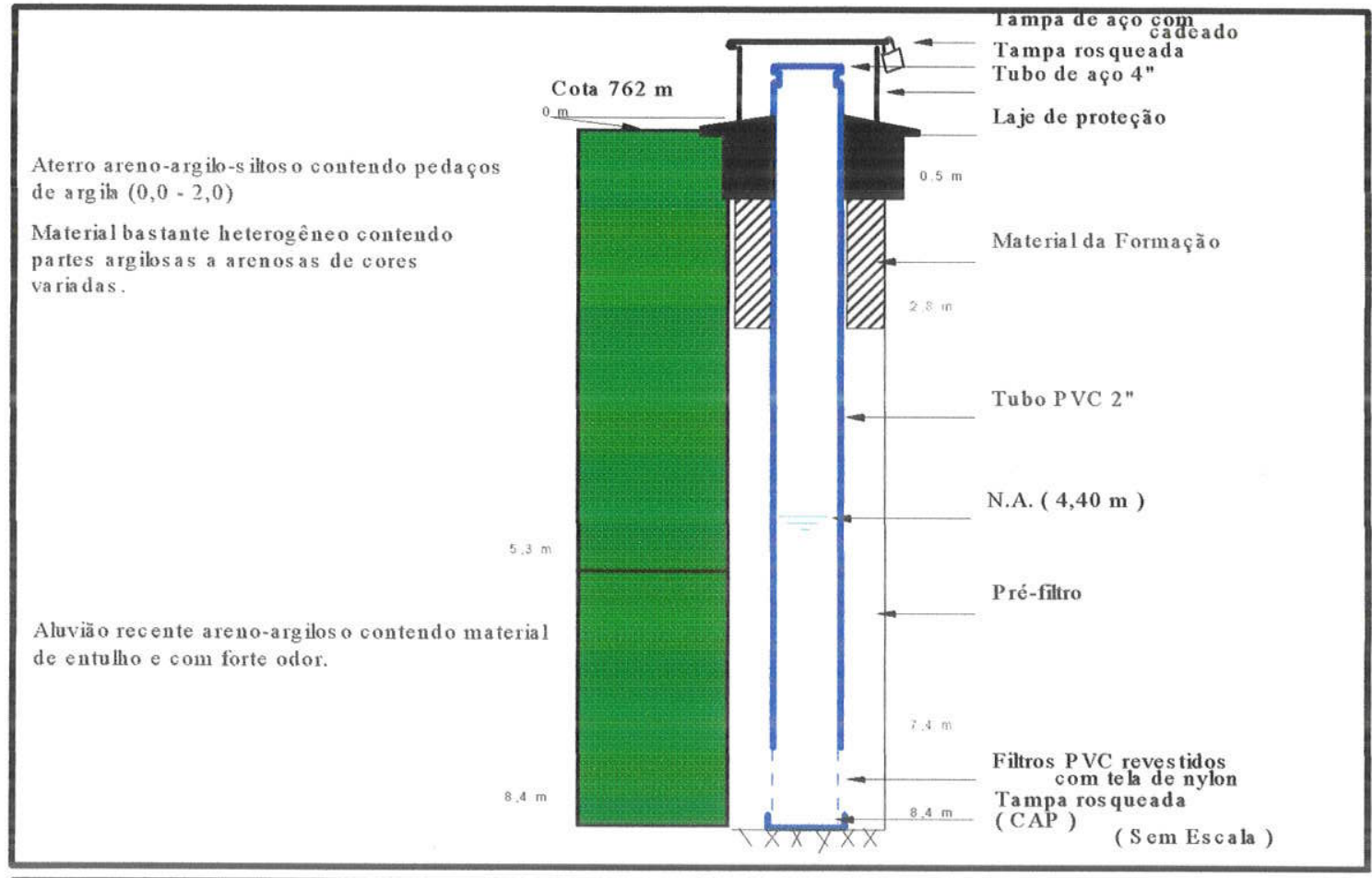

Lo c a 1: Praça Dr. Vicente, Jd. Vera Cruz

D a $\mathrm{ta}: 12$ SET 94

FIGURA 12 - Perfil Litológico e Construtivo do Poço de Monitoramento 12

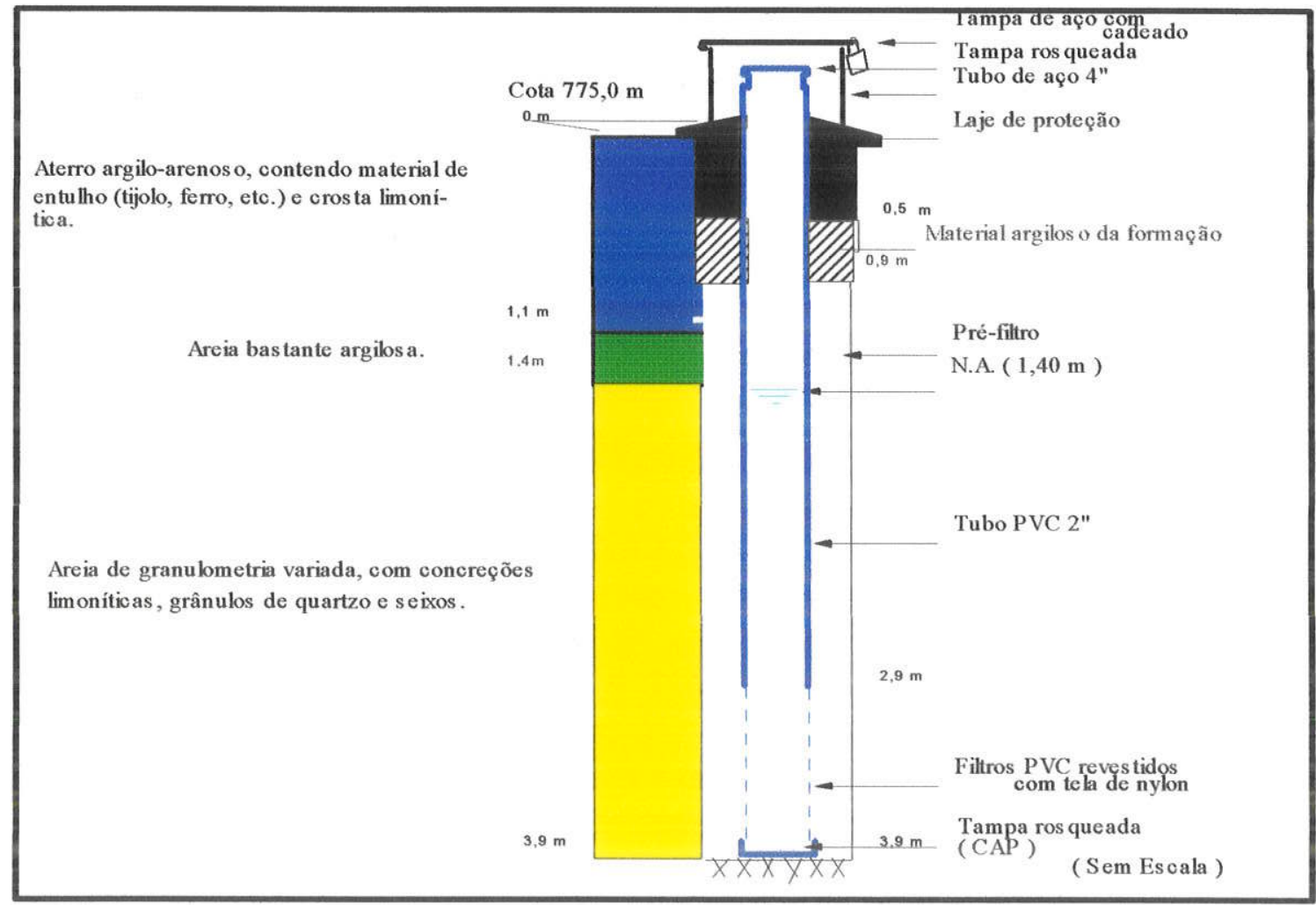

Lo c a 1: Praça Homero Silva, Campus da Escolástica

D a ta :13 SET 94 
FIGURA 13 - Perfil Litológico e Construtivo do Poço de Monitoramento 13

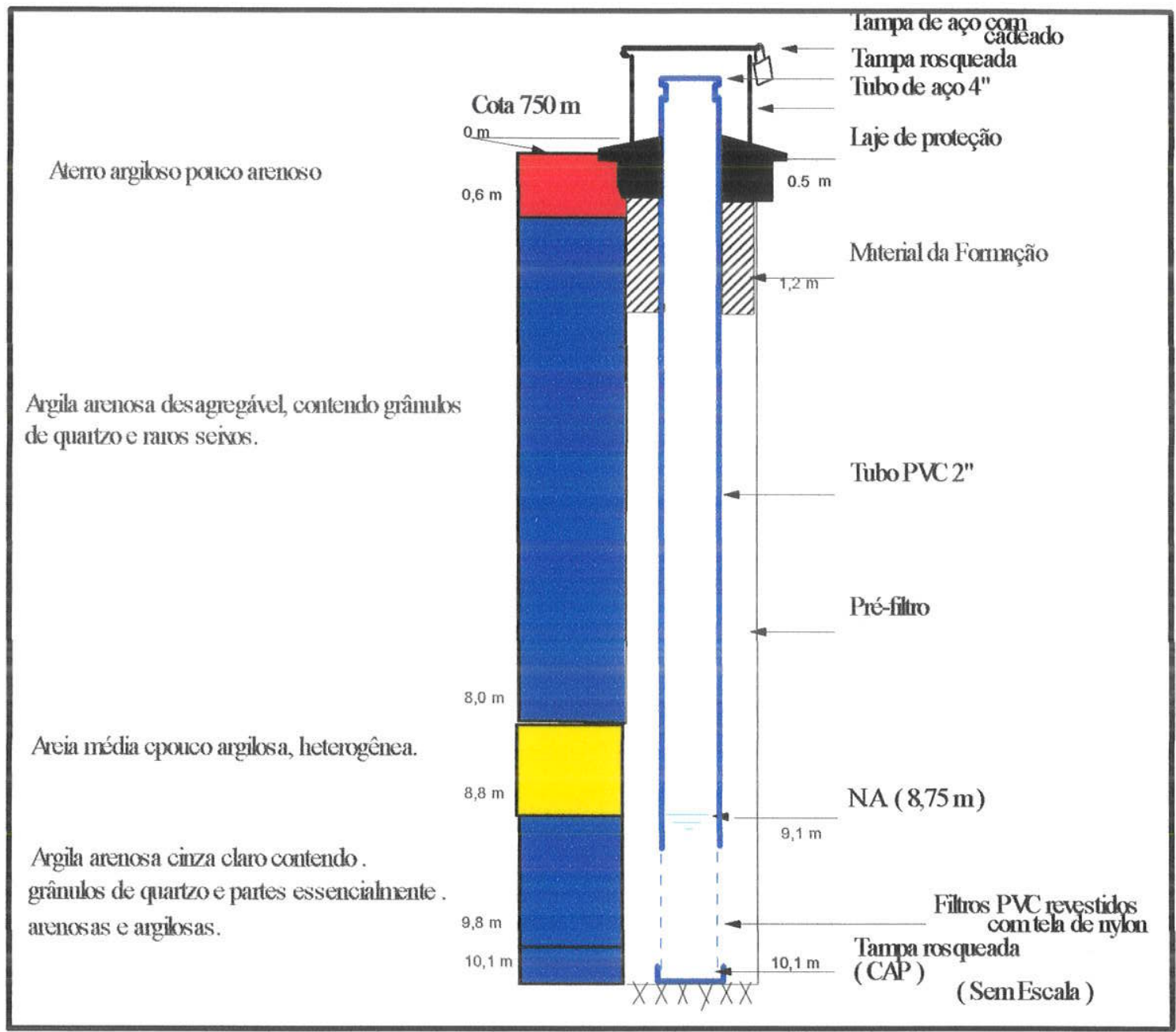

Lo c a 1 : EMEI Santos Dumont, Pompéia

Da ta : 15 SET 94 


\section{ANEXO 2:}

Gráficos: Curvas granulométricas dos solos amostrados nos Poços de Monitoramento 3, 5, 6, 8, 9, 10, 12 e 13, Figuras 1 a 8 respectivamente.

Figura 9 - Curvas granulométricas das areias nos Poços de Monitoramento 6, 4, 5 e 12. 


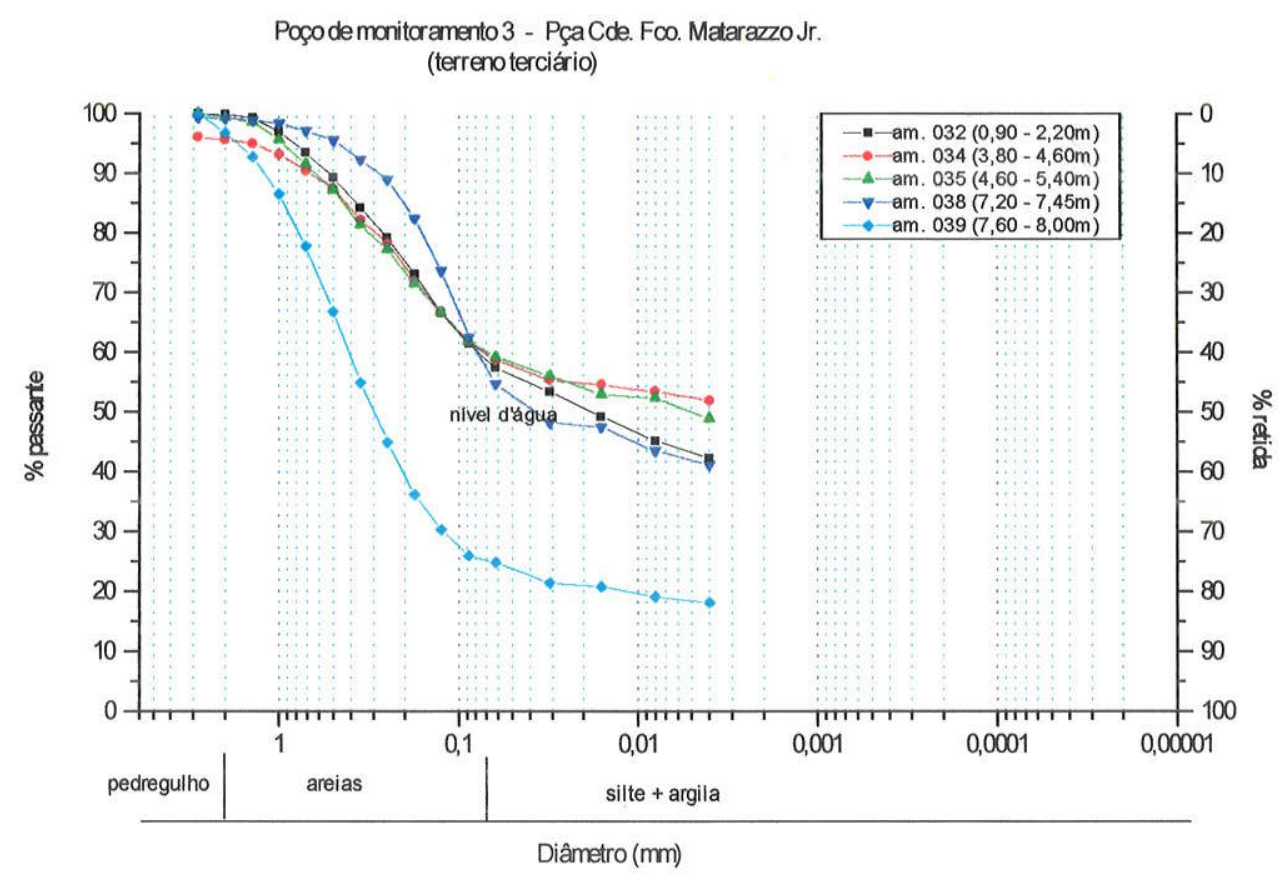

FIGURA 1 - Curvas granulométricas

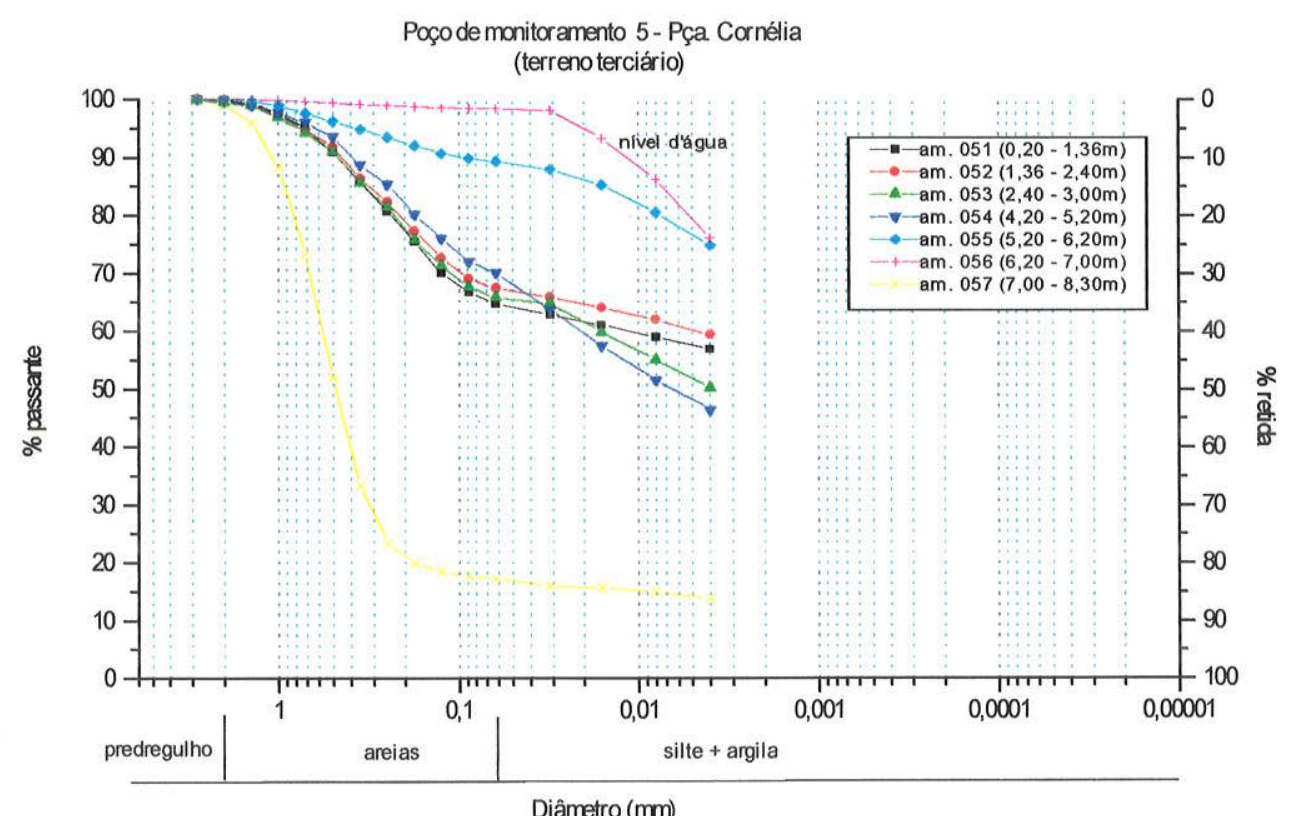

FIGURA 2 - Curvas granulométricas 


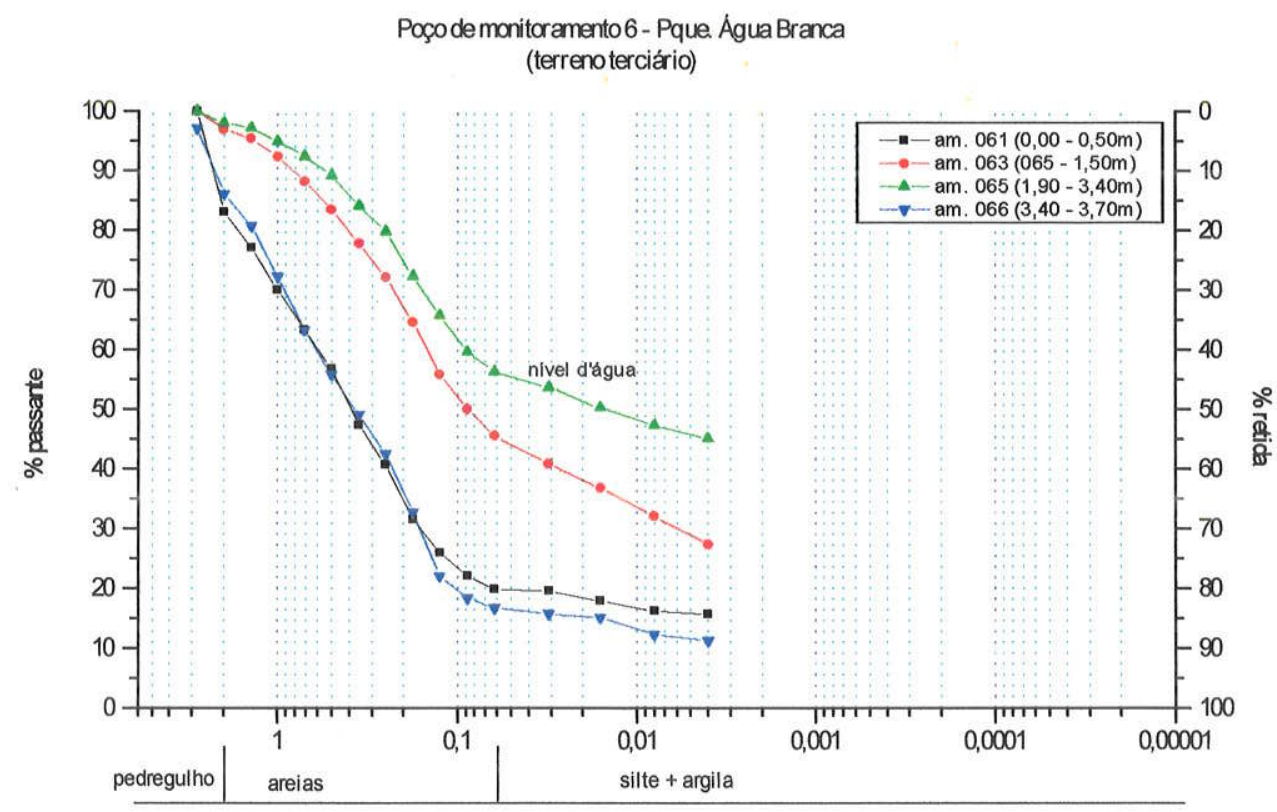

Diâmetro $(\mathrm{mm})$

FIGURA 3 - Curvas granulométricas

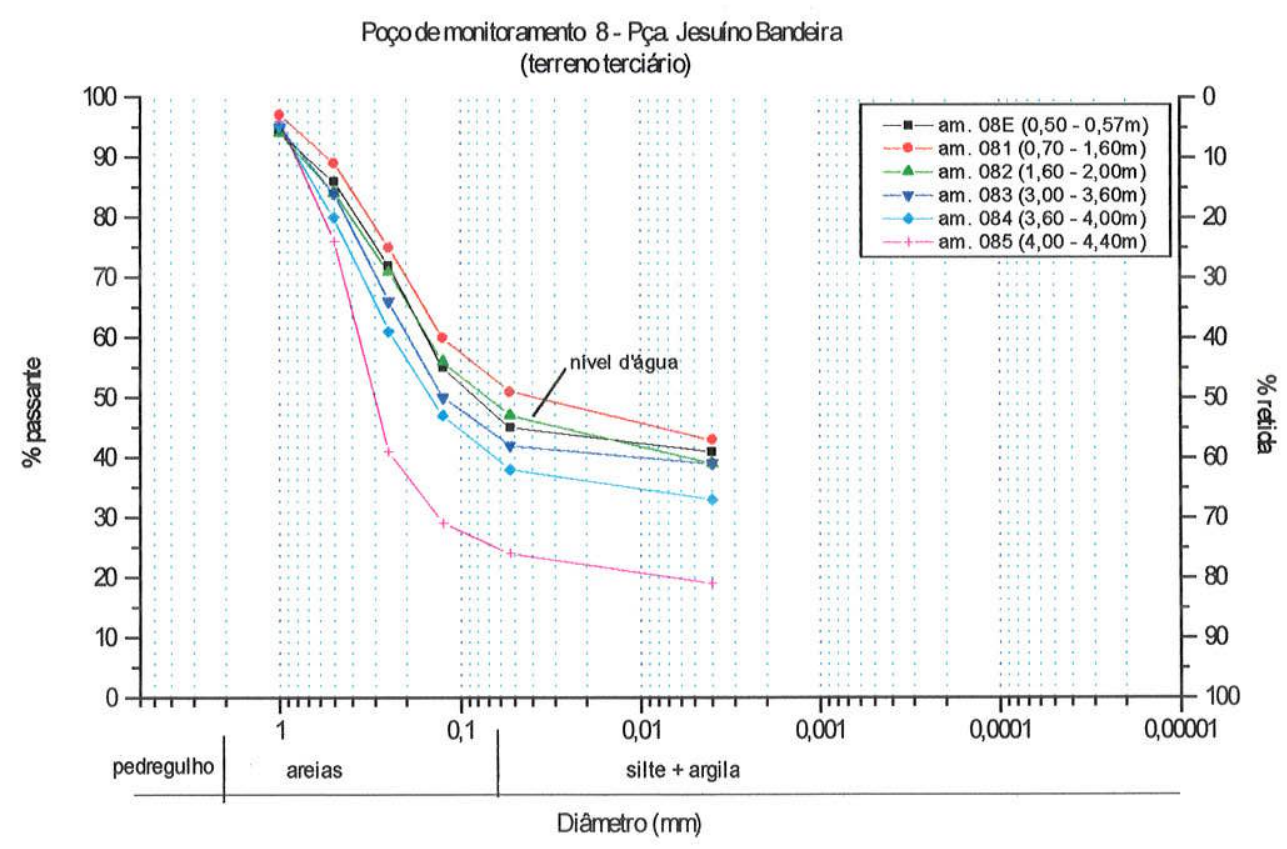

FIGURA 4 - Curvas granulométricas 


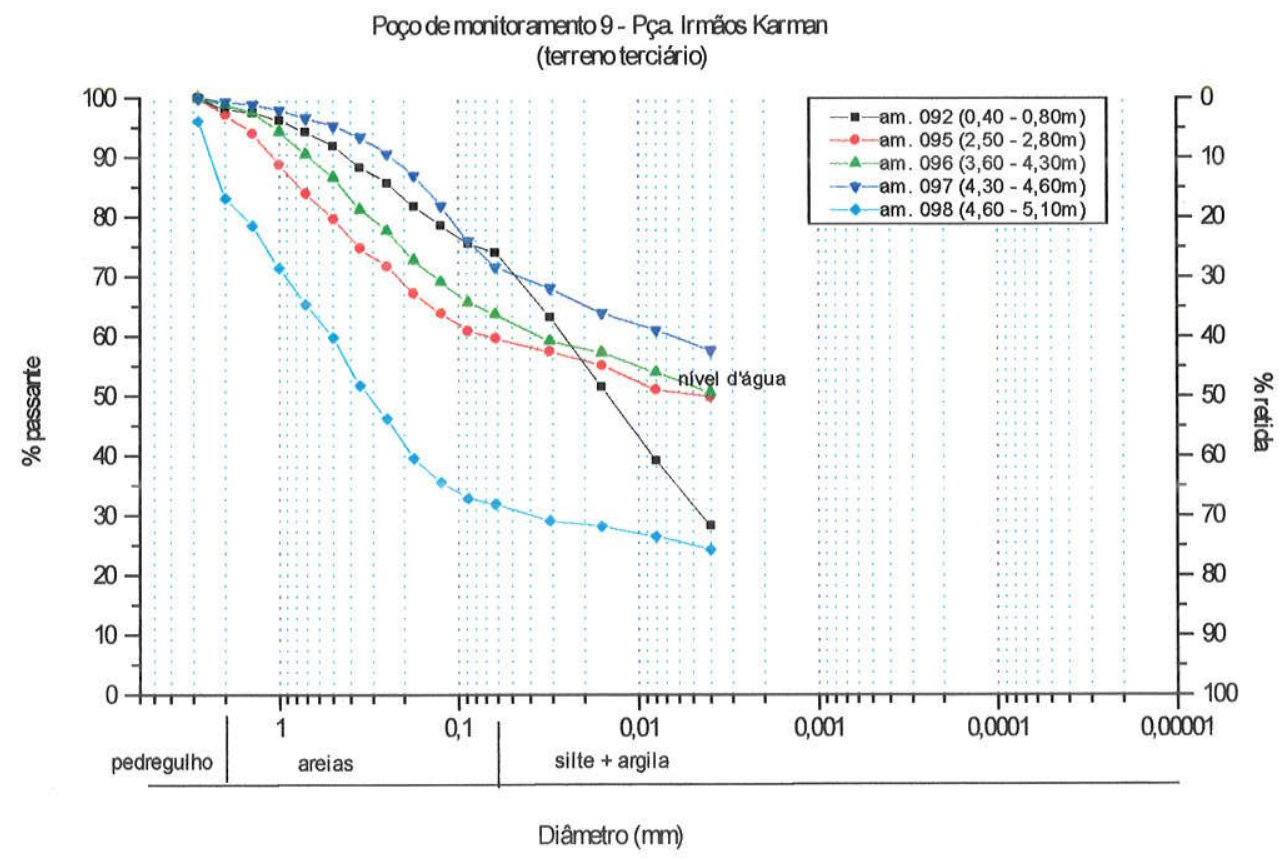

FIGURA 5 - Curvas granulométricas

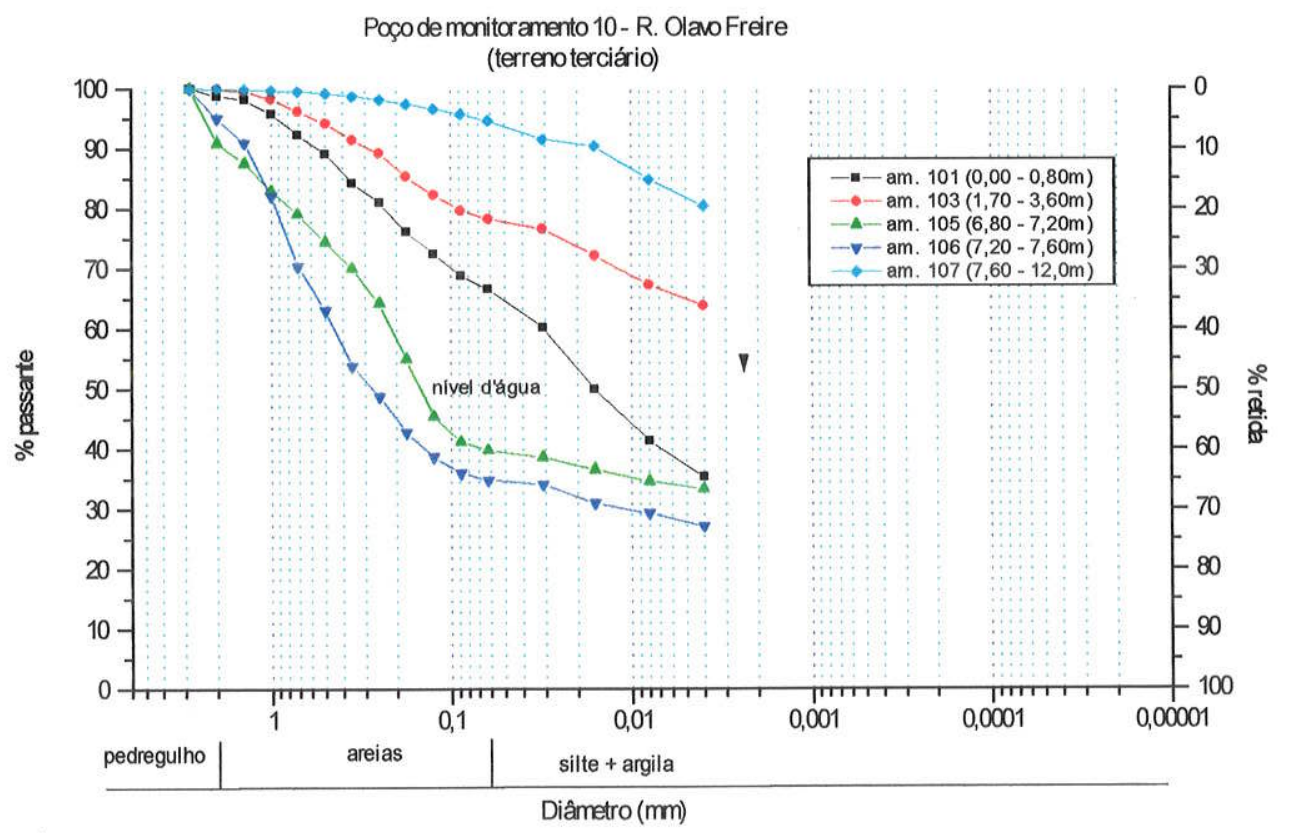

FIGURA 6 - Curvas granulométricas 


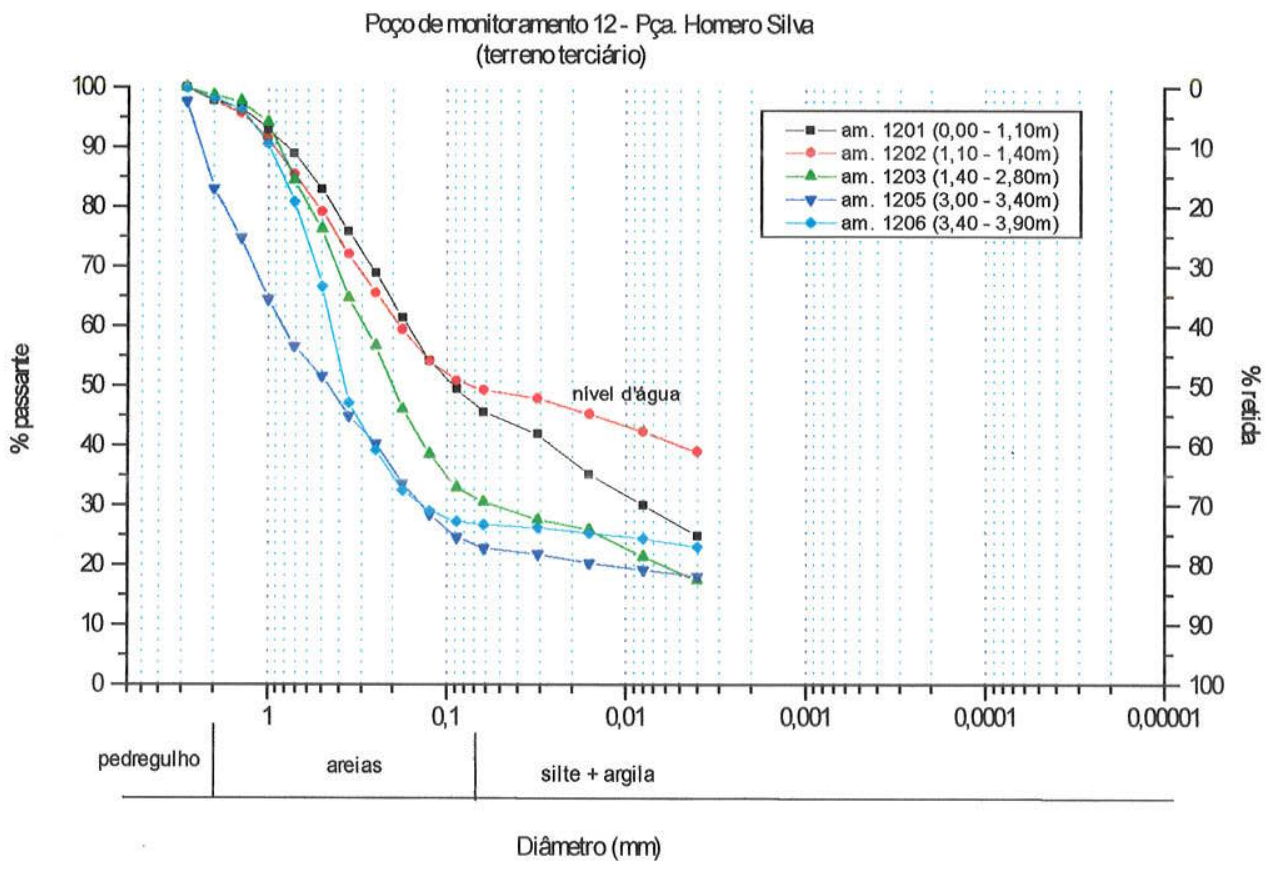

FIGURA 7 - Curvas granulométricas

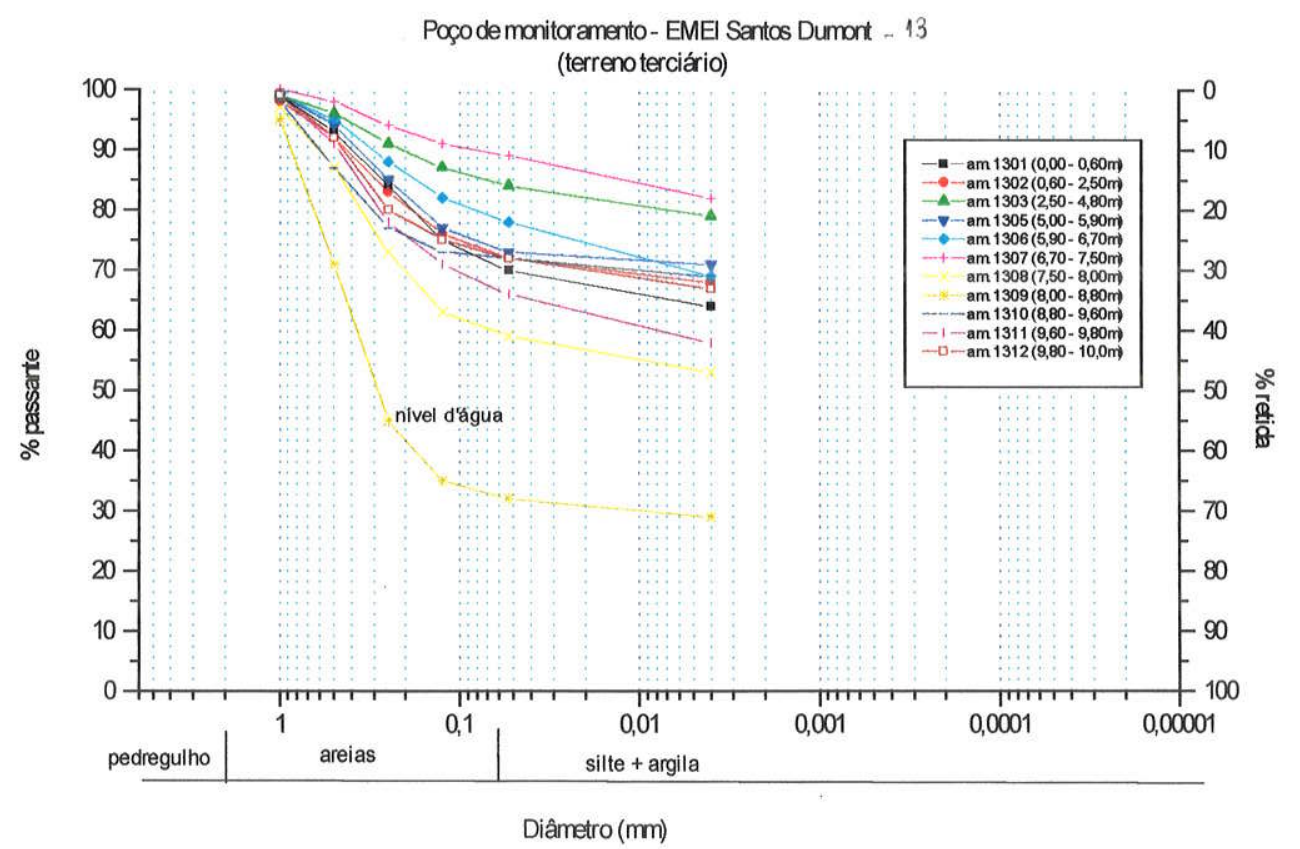

FIGURA 8 - Curvas granulométricas 


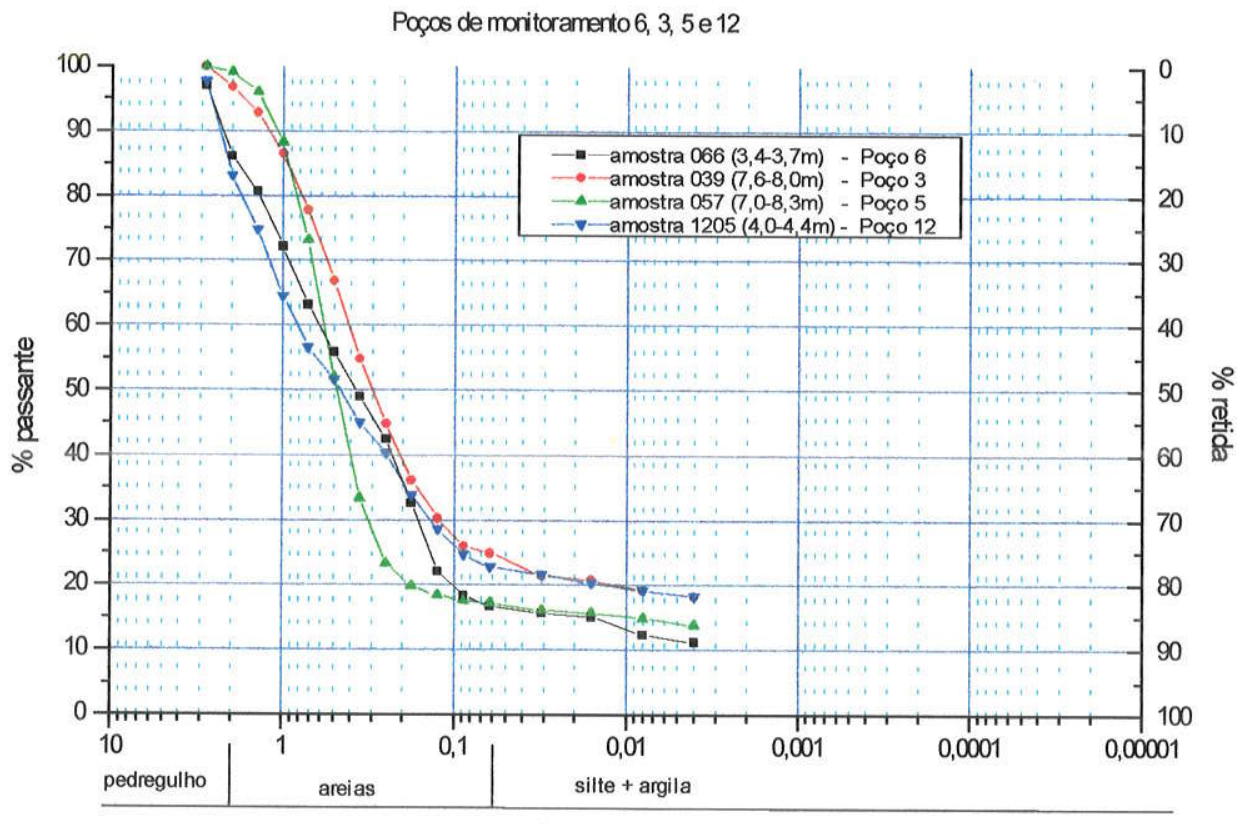

Diâmetro $(\mathrm{mm})$

FIGURA 9 - Curvas granulométricas 


\section{ANEXO 3:}

Planilhas de campo: Precipitação - oscilação do nível freático nos Poços de Monitoramento 1, 2, 3, 4, 5, 6, 7, 8, 9, 10, 11, 12, 13 (leituras quinzenais-mensais); e nos Poços 3, 5, 6, 8, 9, 10, 12 e 13 (leituras de 4 em 4 dias) 
POÇO PM-01 - Ponte do Limão (B. Funda)

\begin{tabular}{|c|c|c|c|c|c|c|c|c|}
\hline DATA & INTERVALO & No. DIAS & PRECIPITAÇÃO & PRECIPITAÇÃO & PROF. NIVEL & $\Delta \mathbf{h}$ & $h \max -h \min$ & $\operatorname{sh}(+)$ \\
\hline MEDIÇÄO & & ACUMULADOS & NO INTERVALO & ACUMULADA & D'ÁGUA - h & & $(m)$ & $(m)$ \\
\hline DO N.A. & (dias) & & $(\mathrm{mm})$ & $(\mathbf{m m})$ & (m) & & & \\
\hline $21 /$ set./94 & - & 0 & - & - & 3,1 & & \multirow{18}{*}{2,46} & \multirow{18}{*}{2,98} \\
\hline 25/out/94 & 34 & 34 & 32 & 32 & 3.1 & 0 & & \\
\hline 23/nov/94 & 29 & 63 & 130,2 & 162,2 & 3 & 0,1 & & \\
\hline $06 /$ dez/94 & 13 & 76 & 102.3 & 264,5 & 2,88 & 0,12 & & \\
\hline 20/dez/94 & 14 & 90 & 118,9 & 383,4 & 2,43 & 0,45 & & \\
\hline $04 /$ jan/95 & 15 & 105 & 174,3 & 557.7 & 1,22 & 1,21 & & \\
\hline 24/jan/95 & 20 & 125 & 132 & 689,7 & 1,53 & $-0,31$ & & \\
\hline $14 / \mathrm{fev} / 95$ & 21 & 146 & 470,1 & 1159,8 & 0,64 & 0,89 & & \\
\hline $07 / \mathrm{mar} / 95$ & 21 & 167 & 142,4 & 1302,2 & 1,55 & $-0,91$ & & \\
\hline $21 / \mathrm{mar} / 95$ & 14 & 181 & 103,7 & 1405,9 & 1,46 & 0.09 & & \\
\hline 11/abr/95 & 21 & 202 & 126,9 & 1532,8 & 1,73 & $-0,27$ & & \\
\hline $25 / a b r / 95$ & 14 & 216 & 39,2 & 1572 & 2,26 & $-0,53$ & & \\
\hline 25/mai/95 & 30 & 246 & 61,4 & 1633.4 & 2,8 & $-0,54$ & & \\
\hline 26/jun/95 & 32 & 278 & 39 & 1672,4 & 3,03 & $-0,23$ & & \\
\hline $26 /$ ul/95 & 30 & 308 & 69,2 & 1741,6 & 2,91 & 0,12 & & \\
\hline $25 / a g o / 95$ & 30 & 338 & 21,7 & 1763,3 & 3,05 & $-0,14$ & & \\
\hline $22 / \mathrm{set} / 95$ & 28 & 366 & 11,9 & 1775,2 & 3,05 & 0 & & \\
\hline 27/out/95 & 35 & 401 & 205,7 & 1980,9 & 2,41 & 0,64 & & \\
\hline
\end{tabular}

POCO PM-02 - Pca. Pascoal Martins (B. Funda)

\begin{tabular}{|c|c|c|c|c|c|c|c|c|}
\hline $\begin{array}{c}\text { DATA } \\
\text { MEDIÇÃO } \\
\text { DO N.A. }\end{array}$ & $\begin{array}{c}\text { INTERVALO } \\
\text { (dias) }\end{array}$ & $\begin{array}{c}\text { No. DIAS } \\
\text { ACUMULADOS }\end{array}$ & $\begin{array}{c}\text { PRECIPITAÇÃO } \\
\text { NO INTERVALO } \\
\text { (mm) }\end{array}$ & $\begin{array}{c}\text { PRECIPITAÇÃO } \\
\text { ACUMULADA } \\
\text { (mm) }\end{array}$ & $\begin{array}{l}\text { PROF. NIVEL } \\
\text { DAGUA - h } \\
\text { (m) }\end{array}$ & $\begin{array}{l}\Delta h \\
(m)\end{array}$ & $\begin{array}{c}\text { hmax }-\mathrm{hmin} \\
\text { (m) }\end{array}$ & $\begin{array}{c}\Sigma h(+) \\
(m)\end{array}$ \\
\hline $21 /$ set $/ 94$ & - & 0 & - & - & 1,92 & & \multirow{18}{*}{1,07} & \multirow{18}{*}{1,31} \\
\hline 25/out/94 & 34 & 34 & 32 & 32 & 2 & & & \\
\hline $23 /$ nov/94 & 29 & 63 & 130,2 & 162,2 & 1,83 & & & \\
\hline 06/dez/94 & 13 & 76 & 102,3 & 264,5 & 2 & & & \\
\hline 20/dez/94 & 14 & 90 & 118,9 & 383,4 & 1,62 & & & \\
\hline $04 /$ Jan/95 & 15 & 105 & 174,3 & 557,7 & 1,35 & & & \\
\hline $24 /$ an/95 & 20 & 125 & 132 & 689,7 & 1,39 & & & \\
\hline 14/fev/95 & 21 & 146 & 470,1 & 1159,8 & 0,96 & & & \\
\hline 07/mari95 & 21 & 167 & 142,4 & 1302,2 & 1,54 & & & \\
\hline $21 /$ mar/95 & 14 & 181 & 103,7 & 1405,9 & 1,48 & & & \\
\hline 11/abr/95 & 21 & 202 & 126,9 & 1532,8 & 1,56 & & & \\
\hline $25 / a b t / 95$ & 14 & 216 & 39.2 & 1572 & 1,65 & & & \\
\hline $25 / \mathrm{mai} / 95$ & 30 & 246 & 61,4 & 1633,4 & 1,86 & & & \\
\hline 26jun/95 & 32 & 278 & 39 & 1672,4 & 2,03 & & & \\
\hline 26/juv95 & 30 & 308 & 69,2 & 1741,6 & - & & & \\
\hline $25 \mathrm{lag} / 95$ & 30 & 338 & 21,7 & 1763,3 & - & & & \\
\hline 22/set/95 & 28 & 366 & 11,9 & 1775,2 & + & & & \\
\hline 27/out/95 & 35 & 401 & 205,7 & 1980,9 & - & & & \\
\hline
\end{tabular}


POÇO PM-03 - PÇa. FCo. Matarazzo (Pompéia)

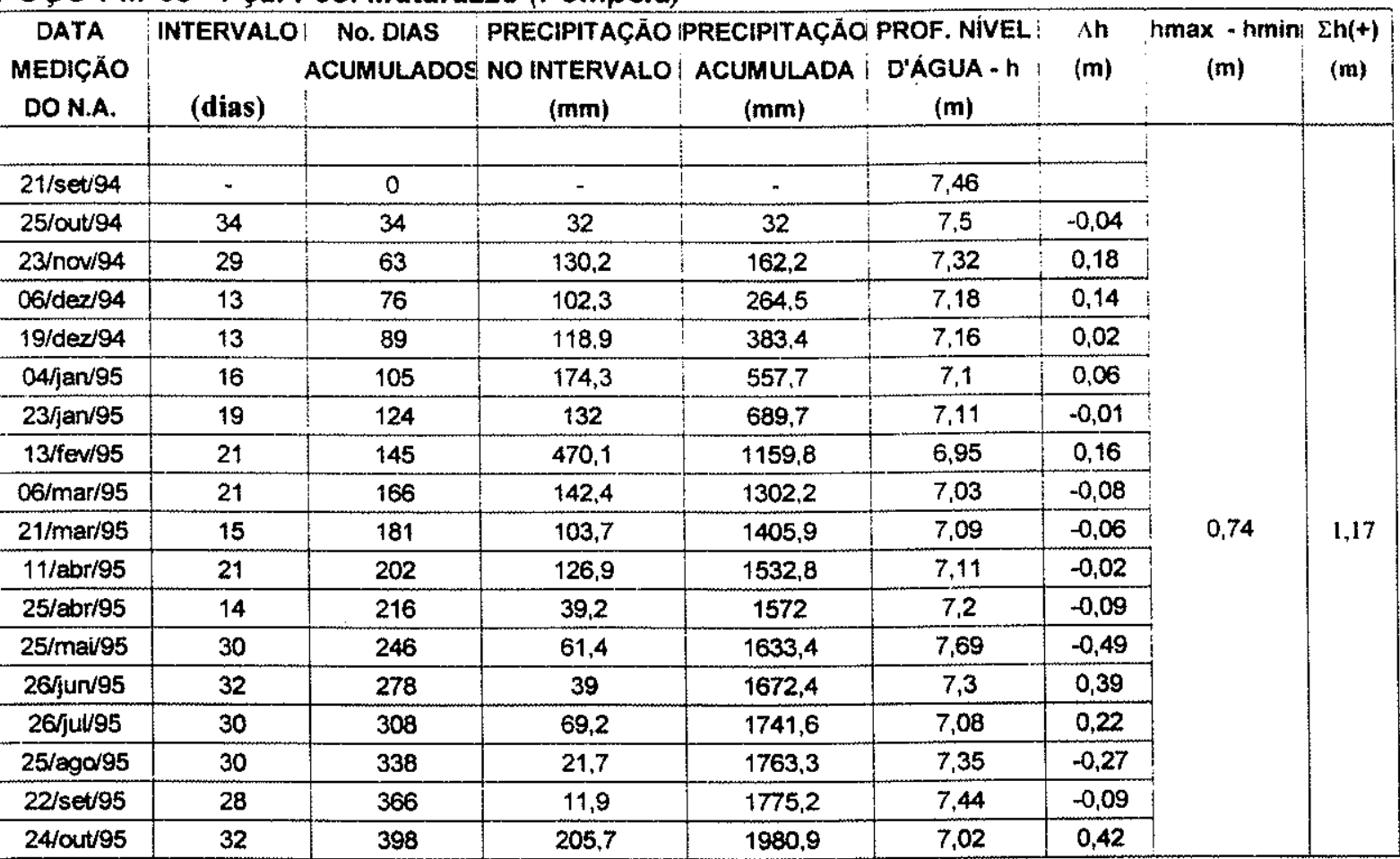

MEDIDAS DE 4 EM 4 DIAS
\begin{tabular}{|c|c|c|c|c|c|c|}
\hline $22 /$ set/95 & - & 0 & - & & 7,44 & \\
\hline $26 /$ set/95 & 4 & 4 & 21,8 & 21,8 & 7,46 & 0,02 \\
\hline $29 /$ set/95 & 3 & 7 & 1,4 & 23,2 & 7,46 & 0 \\
\hline $03 /$ out/95 & 5 & 12 & 0 & 23,2 & 7,46 & 0 \\
\hline $06 /$ out/95 & 3 & 15 & 7,6 & 38,8 & 7,45 & 0,01 \\
\hline $10 /$ out/95 & 4 & 19 & 9,9 & 40,7 & 7,44 & 0,01 \\
\hline $16 /$ out/95 & 6 & 25 & 27,1 & 67,8 & 7,4 & 0,04 \\
\hline $19 /$ out/95 & 3 & 28 & 20,1 & 87,9 & 7,15 & 0,25 \\
\hline $24 /$ out/95 & 5 & 33 & 31,3 & 119,2 & 7,02 & 0,13 \\
\hline $27 /$ out/95 & 4 & 37 & 0 & 119,2 & 7,11 & $-0,09$ \\
\hline $31 /$ out/95 & 4 & 41 & 22,6 & 141,8 & 7,08 & 0,03 \\
\hline $03 /$ nov/95 & 3 & 44 & 5,2 & 147 & 7,09 & $-0,01$ \\
\hline
\end{tabular}

POÇO PM-04 - R. da Várzea (B. Funda)

\begin{tabular}{|c|c|c|c|c|c|c|c|c|}
\hline & INTERVALO| & No. DIAS & PRECIPITAÇÄO & PRECIPITAÇÃd & PROF. NIVEL & $\Delta \boldsymbol{h}$ & $h \max -h \min$ & $\Sigma h(+)$ \\
\hline $\begin{array}{l}\text { MEDIÇÄO } \\
\text { DO N.A. }\end{array}$ & (dias) & ACUMULADOS & $\begin{array}{c}\text { NO INTERVALO } \\
(\mathrm{mm})\end{array}$ & $\begin{array}{c}\text { ACUMULADA } \\
(\mathbf{m m})\end{array}$ & $\begin{array}{c}\text { D'ÁGUA - h } \\
(\mathrm{m})\end{array}$ & (m) & (m) & (m) \\
\hline $21 / 09 / 94$ & - & 0 & - & - & 2.25 & & & \\
\hline 25/out/94 & 34 & 34 & 32 & 32 & 2.29 & $-0,04$ & & \\
\hline $23 /$ nov/94 & 29 & 63 & 130,2 & 162,2 & 2,16 & 0,13 & & \\
\hline $06 / \mathrm{dez} / 94$ & 13 & 76 & 102,3 & 264,5 & 1,98 & 0,18 & & \\
\hline $20 /$ dez/94 & 14 & 90 & 118,9 & 383,4 & 1,81 & 0,17 & & \\
\hline $04 / \mathrm{jan} / 95$ & 15 & 105 & 174,3 & 557,7 & 1,7 & 0,11 & & \\
\hline $23 / \mathrm{an} / 94$ & 19 & 124 & 132 & 689,7 & 1,84 & $-0,14$ & & \\
\hline 14/fev/95 & 22 & 146 & 470,1 & 1159,8 & 1,76 & 0,08 & 0,59 & 0.85 \\
\hline $07 /$ mar/95 & 21 & 167 & 142,4 & 1302,2 & 1,93 & $-0,17$ & & \\
\hline $21 /$ mar/95 & 14 & 181 & 103,7 & 1405,9 & 1,9 & 0,03 & & \\
\hline 11/abr/95 & 21 & 202 & 126,9 & 1532,8 & 1,94 & 0,04 & & \\
\hline 25/abr/95 & 14 & 216 & 39,2 & 1572 & - & - & & \\
\hline $25 / \mathrm{mai} / 95$ & 30 & 246 & 61,4 & 1633,4 & 2,08 & $-0,14$ & & \\
\hline 26/jun/95 & 32 & 278 & 39 & 1672,4 & 2,21 & $-0,13$ & & \\
\hline $26 /$ /u/95 & 30 & 308 & 69,2 & 1741,6 & 2,1 & 0,11 & & \\
\hline $25 /$ ago/95 & 30 & 338 & 21,7 & 1763,3 & 2,15 & $-0,05$ & & \\
\hline $22 / \mathrm{set} / 95$ & 28 & 366 & 11,9 & 1775,2 & 2,2 & $-0,05$ & & \\
\hline 27/out/95 & 35 & 401 & 205,7 & 1980,9 & 4,83 & 0,37 & $\cdots$ & \\
\hline
\end{tabular}


POÇO PM-05 - Pça. Cornélia (Lapa)

\begin{tabular}{|c|c|c|c|c|c|c|c|c|}
\hline DATA & INTERVALO & No. DIAS & PRECIPITACÄO & PRECIPITAÇĂO & PROF. NIVEL ! & $\Lambda \mathbf{h}$ & $h \max -\mathrm{hmin}$ & $\Sigma h(t)$ \\
\hline $\begin{array}{l}\text { MEDIÇĀO } \\
\text { DO N.A. }\end{array}$ & (dias) & ACUMULADOS & $\begin{array}{c}\text { NO INTERVALO } \\
(\mathrm{mm})\end{array}$ & $\begin{array}{c}\text { ACUMULADA } \\
(\mathrm{mm})\end{array}$ & $\begin{array}{c}\text { D'ÁGUA - h } \\
\text { (m) }\end{array}$ & (m) & (m) & (m) \\
\hline $21 / \mathrm{se} / 94$ & - & 0 & - & - & 7.70 & & \multirow{18}{*}{2,46} & \multirow{18}{*}{2,66} \\
\hline 25/out/94 & 34 & 34 & 32 & 32 & 7.66 & 0,04 & & \\
\hline 22/nov/94 & 28 & 62 & $\uparrow 30,2$ & 162.2 & 7,48 & 0,18 & & \\
\hline $06 /$ dez/94 & 14 & 76 & 102.3 & 264,5 & 7,2 & 0,28 & & \\
\hline 19/dez/94 & 13 & 89 & 118,9 & 383,4 & 6,89 & 0,31 & & \\
\hline $03 /$ Jan/95 & 15 & 104 & 157,9 & 541,3 & 6,52 & 0,37 & & \\
\hline 24/jan/95 & 21 & 125 & 148,4 & 689,7 & 6.61 & $-0,09$ & & \\
\hline 13/fev/95 & 20 & 145 & 452,8 & 1142.5 & 5,31 & 1,3 & & \\
\hline $06 /$ mar/95 & 21 & 166 & 158,6 & 1301,1 & 6,06 & $-0,75$ & & \\
\hline $21 / \operatorname{mar} / 95$ & 15 & 181 & 104,8 & 1405,9 & 6,42 & $-0,36$ & & \\
\hline 11/abr/95 & 21 & 202 & 126,9 & 1532,8 & 6,58 & $-0,16$ & & \\
\hline 25/abr/95 & 14 & 216 & 39,2 & 1572 & 6,75 & $-0,17$ & & \\
\hline $25 / \mathrm{mai} / 95$ & 30 & 246 & 61,4 & 1633,4 & 6,92 & $-0,17$ & & \\
\hline $26 / j u n / 95$ & 32 & 278 & 39 & 1672,4 & 7,1 & $-0,18$ & & \\
\hline 26/jul/95 & 30 & 308 & 69,2 & 1741,6 & 6,92 & 0,18 & & \\
\hline $25 / a g d / 95$ & 30 & 338 & 21,7 & 1763,3 & 7,72 & $-0,8$ & & \\
\hline 22/set/95 & 28 & 366 & 11,9 & 1775,2 & 7,77 & $-0,05$ & & \\
\hline $24 /$ out $/ 95$ & 32 & 398 & 205.7 & 1980,9 & 7,02 & 0,75 & & \\
\hline
\end{tabular}

MEDIDAS DE 4 EM 4 DIAS
\begin{tabular}{|c|c|c|c|c|c|c|}
\hline $22 / \mathrm{se} / 95$ & - & 0 & - & & 7,77 & \\
\hline $26 / \mathrm{set} / 95$ & 4 & 4 & 21,8 & 21,8 & 7,68 & 0,09 \\
\hline $29 / \mathrm{set} / 95$ & 3 & 7 & 1,4 & 23,2 & 7,66 & 0,02 \\
\hline $03 /$ out/95 & 5 & 12 & 0 & 23,2 & 7,65 & 0,01 \\
\hline $06 /$ out/95 & 3 & 15 & 7,6 & 38,8 & 7,64 & 0,01 \\
\hline $10 /$ out/95 & 4 & 19 & 9,9 & 40,7 & 7,62 & 0,02 \\
\hline 16/out/95 & 6 & 25 & 27,1 & 67,8 & 7,59 & 0,03 \\
\hline $19 /$ out/95 & 3 & 28 & 20,1 & 87,9 & 7,08 & 0,51 \\
\hline $24 /$ out/95 & 5 & 33 & 31,3 & 119,2 & 7,02 & 0,06 \\
\hline $27 /$ out/95 & 4 & 37 & 0 & 119,2 & 7,09 & $-0,07$ \\
\hline $31 /$ out/95 & 4 & 41 & 22,6 & 141,8 & 7,06 & 0,03 \\
\hline $03 /$ nov/95 & 3 & 44 & 5,2 & 147 & 7,13 & $-0,07$ \\
\hline
\end{tabular}


POÇO PM-06 - Pque. Água Branca (Água Branca)

\begin{tabular}{|c|c|c|c|c|c|c|c|c|}
\hline DATA & INTERVALO & No. DIAS & PRECIPITAÇÃO & PRECIPITAÇÄO & PROF. NIVEL! & $\Delta h$ & hmax - hmini & $\operatorname{sh}(+)$ \\
\hline $\begin{array}{l}\text { MEDIÇÄO } \\
\text { DO N.A. }\end{array}$ & (dias) & ACUMULADOS & $\begin{array}{c}\text { NO INTERVALO } \\
(\mathrm{mm})\end{array}$ & $\begin{array}{l}\text { ACUMULADA } \\
(\mathrm{mm})\end{array}$ & $\begin{array}{c}\text { D'ÁGUA - } h \\
\text { (m) }\end{array}$ & (m) & $(\mathbf{m})$ & $(\mathbf{m})$ \\
\hline $21 /$ set $/ 94$ & - & 0 & - & - & 1,85 & & \multirow{18}{*}{0,29} & \multirow{18}{*}{0.48} \\
\hline 25/out/94 & 34 & 34 & 32 & 32 & 1,84 & 0,01 & & \\
\hline 22/nov/94 & 28 & 62 & 130,2 & 162,2 & 1,83 & 0,01 & & \\
\hline $06 /$ dez/94 & 14 & 76 & 102,3 & 264,5 & 1,74 & 0,09 & & \\
\hline 19/dez/94 & 13 & 89 & 118,9 & 383,4 & 1,74 & 0 & & \\
\hline $04 / \mathrm{jan} / 95$ & 16 & 105 & 174,3 & 557.7 & 1,65 & 0,09 & & \\
\hline 24/jan/95 & 20 & 125 & 132 & 689.7 & 1,74 & $-0,09$ & & \\
\hline 13/fev/95 & 20 & 145 & 452.8 & 1142,5 & 1,56 & 0,18 & & \\
\hline $06 /$ mar/95 & 21 & 166 & 158,6 & 1301,1 & 1,65 & $-0,09$ & & \\
\hline $21 / \mathrm{mar} / 95$ & 15 & 181 & 104,8 & 1405,9 & 1,63 & 0,02 & & \\
\hline 11/abr/95 & 21 & 202 & 126,9 & 1532,8 & 1,76 & $-0,13$ & & \\
\hline 25/abr/95 & 14 & 216 & 39,2 & 1572 & 1,78 & $-0,02$ & & \\
\hline $25 / \mathrm{mai} / 95$ & 30 & 246 & 61,4 & 1633,4 & 1,85 & $-0,07$ & & \\
\hline 26/jun/95 & 32 & 278 & 39 & 1672,4 & 1,81 & 0,04 & & \\
\hline 26/jul/95 & 30 & 308 & 69,2 & 1741,6 & 1,77 & 0,04 & & \\
\hline 25 /ago/95 & 30 & 338 & 21,7 & 1763,3 & 1,79 & $-0,02$ & & \\
\hline $22 / \mathrm{set} / 95$ & 28 & 366 & 11,9 & 1775,2 & 1,85 & $-0,06$ & & \\
\hline 24/out/95 & 32 & 398 & 205,7 & 1980,9 & 1,79 & 0,06 & & \\
\hline
\end{tabular}

\begin{tabular}{|l|c|c|c|c|c|c|}
\hline $22 /$ set/95 & - & 0 & - & - & 1,85 & \\
\hline $26 /$ set/95 & 4 & 4 & 21,8 & 21,8 & 1,79 & 0,06 \\
\hline $29 /$ set/95 & 3 & 7 & 1,4 & 23,2 & 1,77 & 0,02 \\
\hline $03 /$ out/95 & 5 & 12 & 0 & 23,2 & 1,82 & $-0,05$ \\
\hline $06 /$ out/95 & 3 & 15 & 7,6 & 38,8 & 1,87 & $-0,05$ \\
\hline $10 /$ out/95 & 4 & 19 & 9,9 & 40,7 & 1,76 & 0,11 \\
\hline $16 /$ out/95 & 6 & 25 & 27,1 & 67,8 & 1,71 & 0,05 \\
\hline $19 /$ out/95 & 3 & 28 & 20,1 & 87,9 & 1,77 & $-0,06$ \\
\hline $24 /$ out/95 & 5 & 33 & 31,3 & 119,2 & 1,79 & $-0,02$ \\
\hline $27 /$ out/95 & 4 & 37 & 0 & 119,2 & 1,8 & $-0,01$ \\
\hline $31 /$ out/95 & 4 & 41 & 22,6 & 141,8 & 1,76 & 0,04 \\
\hline $03 /$ nov/95 & 3 & 44 & 5,2 & 147 & 1,78 & $-0,02$ \\
\hline
\end{tabular}


POÇO PM-07 - Nacional (B. Funda)

\begin{tabular}{|c|c|c|c|c|c|c|c|c|}
\hline DATA & INTERVALO & No. DIAS & PRECIPITAÇÄO & PRECIPITAÇĀ $\alpha$ & PROF. NIVEL & $\Delta \mathbf{h}$ & hmax - hmin & $\Sigma h(+)$ \\
\hline MEDIÇÄO & & ACUMULADOS & NO INTERVALO & ACUMULADA & D'ÁGUA - h & (m) & (m) & (m) \\
\hline DON.A. & (dias) & & $(\mathbf{m m})$ & $(\mathrm{mm})$ & (m) & & & \\
\hline $23 / 09 / 94$ & - & - & 0 & & 1,24 & & \multirow{18}{*}{0,65} & \multirow{18}{*}{1,32} \\
\hline 25/out/94 & 32 & 32 & 32 & 32 & 1,17 & 0,07 & & \\
\hline 23/nowi94 & 29 & 61 & 130,2 & 162,2 & 0,89 & 0,28 & & \\
\hline 06/dez/94 & 13 & 74 & 102,3 & 264.5 & 0.59 & 0,3 & & \\
\hline 20/dez/94 & 14 & 88 & 118,9 & 383.4 & 0,7 & $-0,11$ & & \\
\hline 04/jan/95 & 15 & 103 & 174,3 & 557,7 & 0,6 & 0,1 & & \\
\hline 23/jan/95 & 19 & 122 & 132 & 689,7 & 0,89 & $-0,29$ & & \\
\hline $14 / f$ ev/95 & 22 & 144 & 470,1 & 1159,8 & 0,61 & 0.28 & & \\
\hline 07/mar/95 & 21 & 165 & 142,4 & 1302,2 & 0,86 & $-0,25$ & & \\
\hline $21 / \operatorname{mar} / 95$ & 14 & 179 & 103,7 & 1405,9 & 0,88 & $-0,02$ & & \\
\hline $11 / a b r / 95$ & 21 & 200 & 126.9 & 1532,8 & 0,96 & $-0,08$ & & \\
\hline 25/abr/95 & 14 & 214 & 39,2 & 1572 & 0,76 & 0,2 & & \\
\hline $25 / \mathrm{mai} / 95$ & 30 & 244 & 61,4 & 1633,4 & 0,96 & $-0,2$ & & \\
\hline 26/jur/95 & 32 & 276 & 39 & 1672,4 & 0,87 & 0,09 & & \\
\hline 26/jul/95 & 30 & 306 & 69,2 & 1741,6 & 0,89 & $-0,02$ & & \\
\hline $25 / a g d / 95$ & 30 & 336 & 21.7 & 1763,3 & 0,98 & $-0,09$ & & \\
\hline $22 / \mathrm{set} / 95$ & 28 & 364 & 11,9 & 1775,2 & 1,05 & $-0,07$ & & \\
\hline 27/out/95 & 35 & 399 & 205,7 & 1980,9 & 0,8 & 0,25 & & \\
\hline
\end{tabular}

POCOO PM-08 - Pça. Jesuino Bandeira (Siciliano)

\begin{tabular}{|c|c|c|c|c|c|c|c|c|}
\hline $\begin{array}{l}\text { DATA } \\
\text { MEDIÇĀo } \\
\text { DON.A. }\end{array}$ & $\begin{array}{c}\text { INTERVALO } \\
\text { (dias) }\end{array}$ & $\begin{array}{c}\text { No. DIAS } \\
\text { ACUMULADOS }\end{array}$ & $\begin{array}{c}\text { PRECIPITACAOO } \\
\text { NO INTERVALO } \\
(\mathrm{mm})\end{array}$ & $\begin{array}{c}\text { PRECIPITAÇÃ } \\
\text { ACUMULADA } \\
\text { (mm) }\end{array}$ & $\begin{array}{c}\text { PROF. NÍVEL } \\
\text { D'ÁGUA - } h \\
\text { (m) }\end{array}$ & $\begin{array}{l}\Delta h \\
(m)\end{array}$ & $\begin{array}{c}\text { hmax }- \text { hmin } \\
\text { (m) }\end{array}$ & $\begin{array}{c}\Sigma \mathrm{h}(+) \\
(\mathrm{m})\end{array}$ \\
\hline $21 /$ set/94 & $\therefore$ & - & - & - & 2.16 & & \multirow{18}{*}{0,8} & \multirow{18}{*}{0,93} \\
\hline 25/out/94 & 34 & 34 & 32 & 32 & 2.25 & $-0,09$ & & \\
\hline 22/nov/94 & 28 & 62 & 130,2 & 162,2 & 2,11 & 0,14 & & \\
\hline $06 / d e z / 94$ & 14 & 76 & 102,3 & 264,5 & 2,09 & 0,02 & & \\
\hline $19 / \mathrm{dez} / 94$ & 13 & 89 & 118,9 & 383,4 & 1,95 & 0,14 & & \\
\hline 03/jan/95 & 15 & 104 & 157,9 & 541,3 & 1,74 & 0,21 & & \\
\hline 24/jar/95 & 21 & 125 & 148,4 & 689.7 & 1,75 & $-0,01$ & & \\
\hline $13 /$ fev/95 & 20 & 145 & 452,8 & 1110,5 & 1,74 & 0,01 & & \\
\hline $06 /$ mar/95 & 21 & 166 & 158,6 & 1301,1 & 1,45 & 0,29 & & \\
\hline $21 / \operatorname{mar} / 95$ & 15 & 181 & 104,8 & 1405,9 & 1,57 & $-0,12$ & & \\
\hline 11/abr/95 & 21 & 202 & 126,9 & 1532,8 & 1,6 & $-0,03$ & & \\
\hline $25 / a b r / 95$ & 14 & 216 & 39,2 & 1572 & 1,61 & $-0,01$ & & \\
\hline $25 / \mathrm{mai} / 95$ & 30 & 246 & 61,4 & 1633,4 & 1,84 & $-0,23$ & & \\
\hline 26/jun/95 & 32 & 278 & 39 & 1672,4 & 1,8 & 0,04 & & \\
\hline 26/jul/95 & 30 & 308 & 69,2 & 1741,6 & 1,72 & 0,08 & & \\
\hline 25/ago/95 & 30 & 338 & 21,7 & 1763,3 & 1,75 & $-0,03$ & & \\
\hline $22 /$ set/95 & 28 & 366 & 11,9 & 1775,2 & 1,9 & $-0,15$ & & \\
\hline 24/out/95 & 32 & 398 & 205,7 & 1980,9 & 1,67 & 0,23 & & \\
\hline
\end{tabular}

\section{MEDIDAS DE 4 EM 4 DIAS}

\begin{tabular}{|c|c|c|c|c|c|c|}
\hline $22 / s e t / 95$ & - & 0 & - & - & 1,9 & \\
\hline $26 /$ set/95 & 4 & 4 & 21,8 & 21,8 & 1,87 & 0,03 \\
\hline $29 /$ set/95 & 3 & 7 & 1,4 & 23,2 & 1,86 & 0,01 \\
\hline $03 /$ out/95 & 5 & 12 & 0 & 23,2 & 1,88 & $-0,02$ \\
\hline $06 /$ out/95 & 3 & 15 & 7,6 & 38,8 & 1,9 & $-0,02$ \\
\hline $10 /$ out/95 & 4 & 19 & 9,9 & 40,7 & 1,88 & 0,02 \\
\hline $16 /$ out/95 & 6 & 25 & 27,1 & 67,8 & 1,79 & 0,09 \\
\hline $19 /$ out/95 & 3 & 28 & 20,1 & 87,9 & 1,68 & 0,11 \\
\hline $24 /$ out/95 & 5 & 33 & 31,3 & 119,2 & 1,67 & 0,01 \\
\hline $27 /$ out/95 & 4 & 37 & 0 & 119,2 & 1,67 & 0 \\
\hline $31 /$ out/95 & 4 & 41 & 22,6 & 141,8 & 1,64 & 0,03 \\
\hline $03 /$ nov/95 & 3 & 44 & 5,2 & 147 & 1,63 & 0,01 \\
\hline
\end{tabular}


POCO PM-09 - Pça. Irmãos Karman (Perdizes)

\begin{tabular}{|c|c|c|c|c|c|c|c|c|}
\hline \multirow{2}{*}{$\begin{array}{c}\text { DATA } \\
\text { MEDIÇÃo } \\
\text { DO N.A. } \\
\end{array}$} & \multirow{2}{*}{$\begin{array}{l}\text { INTERVALO } \\
\text { (dias) }\end{array}$} & \multirow{2}{*}{$\begin{array}{c}\text { No. DIAS } \\
\text { ACUMULADOS }\end{array}$} & \multicolumn{3}{|c|}{ PRECIPITAÇÃO PPRECIPITAÇÄO PROF. NIVEL } & \multirow{2}{*}{$\begin{array}{l}\Delta \mathbf{h} \\
(\mathbf{m})\end{array}$} & \multirow{2}{*}{$\begin{array}{c}\text { hmax - hmin } \\
(\mathrm{m})\end{array}$} & \multirow{2}{*}{$\begin{array}{c}\sum h(+) \\
(\mathrm{m})\end{array}$} \\
\hline & & & $\begin{array}{c}\text { NO INTERVALO } \\
(\mathrm{mm})\end{array}$ & $\begin{array}{c}\text { ACUMULADA } \\
\text { (mm) }\end{array}$ & $\begin{array}{c}\text { D'ÁGUA - h } \\
(\mathrm{m})\end{array}$ & & & \\
\hline $21 / \mathrm{set} / 94$ & - & - & - & 0 & 2,96 & & \multirow{18}{*}{0,43} & \multirow{18}{*}{0,87} \\
\hline 24/out/94 & 33 & 33 & 30,6 & 30.6 & 2,87 & 0,09 & & \\
\hline $22 /$ nov/94 & 29 & 62 & 131,6 & 162.2 & 2,64 & 0,23 & & \\
\hline $06 /$ dez/94 & 14 & 76 & 102,3 & 264,5 & 2,7 & $-0,06$ & & \\
\hline $19 /$ dez/94 & 13 & 89 & 118.9 & 352,8 & 2,67 & 0,03 & & \\
\hline 03/jan/95 & 15 & 104 & 157,9 & 541,3 & 2,55 & 0.12 & & \\
\hline 23/jan/95 & 20 & 124 & 148,4 & 689,7 & 2.7 & $-0,15$ & & \\
\hline 13/fev/95 & 21 & 145 & 452,8 & 1142,5 & 2.55 & 0,15 & & \\
\hline $06 /$ mar/95 & 21 & 166 & 158,6 & 1301,1 & 2,8 & $-0,25$ & & \\
\hline $21 /$ mar/95 & 15 & 181 & 104,8 & 1405,9 & 2,78 & 0,02 & & \\
\hline 11/abr/95 & 21 & 202 & 126,9 & 1532,8 & 2,88 & $-0,1$ & & \\
\hline 25/abr/95 & 14 & 216 & 39,2 & 1572 & 2,83 & 0,05 & & \\
\hline $25 /$ mai/95 & 30 & 246 & 61,4 & 1633,4 & 2,85 & $-0,02$ & & \\
\hline 26/jun/95 & 32 & 278 & 39 & 1672,4 & 2,9 & $-0,05$ & & \\
\hline 26/jul/95 & 30 & 308 & 69,2 & 1741,6 & 2,72 & 0,18 & & \\
\hline 25/ago/95 & 30 & 338 & 21,7 & 1763,3 & 2,85 & $-0,13$ & & \\
\hline 22/set/95 & 28 & 366 & 11,9 & 1775,2 & 2,98 & $-0,13$ & & \\
\hline 24/out/95 & 32 & 398 & 205,7 & 1980,9 & 2,68 & 0,3 & & \\
\hline
\end{tabular}

MEDIDAS DE 4 EM 4 DIAS
\begin{tabular}{|c|c|c|c|c|c|c|}
\hline $22 /$ set/95 & - & 0 & - & - & 2,98 & \\
\hline $26 /$ set/95 & 4 & 4 & 21,8 & 21,8 & 2,93 & 0,05 \\
\hline $29 /$ set/95 & 3 & 7 & 1,4 & 23,2 & 2,85 & 0,08 \\
\hline $03 /$ out/95 & 5 & 12 & 0 & 23,2 & 2,89 & $-0,04$ \\
\hline $06 /$ out/95 & 3 & 15 & 7,6 & 38,8 & 2,88 & 0,01 \\
\hline $10 /$ out/95 & 4 & 19 & 9,9 & 40,7 & 2,91 & $-0,03$ \\
\hline $16 /$ out/95 & 6 & 25 & 27,1 & 67,8 & - & - \\
\hline $19 /$ out/95 & 3 & 28 & 20,1 & 87,9 & 2,66 & 0,25 \\
\hline $24 /$ out/95 & 5 & 33 & 31,3 & 119,2 & 2,68 & $-0,02$ \\
\hline $27 /$ out/95 & 4 & 37 & 0 & 119,2 & 2,71 & $-0,03$ \\
\hline $31 /$ out/95 & 4 & 41 & 22,6 & 141,8 & 2,63 & 0,08 \\
\hline $03 /$ nov/95 & 3 & 44 & 5,2 & 147 & 2,67 & $-0,04$ \\
\hline
\end{tabular}


POÇO PM-10 - R. Olavo Freire (Perdizes)

\begin{tabular}{|c|c|c|c|c|c|c|c|c|}
\hline DATA & INTERVALO & No. DIAS & PRECIPITAÇÄO & PRECIPITAÇĀO & PROF. NIVEL : & $\Delta \mathbf{h}$ & $h \max -h \min$ & $\operatorname{sh}(+)$ \\
\hline $\begin{array}{c}\text { MEDIÇÃo } \\
\text { DO N.A. }\end{array}$ & (dias) & ACUMULADOS & $\begin{array}{c}\text { NO INTERVALO } \\
(\mathrm{mm})\end{array}$ & $\begin{array}{c}\text { ACUMULADA } \\
\text { (mm) }\end{array}$ & $\begin{array}{c}\text { D'ÁGUA - } h \\
\text { (m) }\end{array}$ & (m) & (m) & $(\mathrm{m})$ \\
\hline $21 /$ set/94 & - & - & - & 0 & 7,12 & & \multirow{18}{*}{1,47} & \multirow{18}{*}{1,89} \\
\hline 24/out/94 & 33 & 33 & 30,6 & 30,6 & 7,95 & $-0,83$ & & \\
\hline 22 /nov/94 & 29 & 62 & 131,6 & 162,2 & 7,05 & 0,9 & & \\
\hline $06 /$ dez/94 & 14 & 76 & 102,3 & 264,5 & 6,57 & 0,48 & & \\
\hline 19/dez/94 & 13 & 89 & 118,9 & 352.8 & 6,48 & 0,09 & & \\
\hline 03/jan/95 & 15 & 104 & 157,9 & 541.3 & 6.48 & 0 & & \\
\hline 23/jan/95 & 20 & 124 & 148,4 & 689.7 & 7,04 & $-0,56$ & & \\
\hline $13 /$ fev/95 & 21 & 145 & 452,8 & 1142,5 & 6,88 & 0,16 & & \\
\hline 06/mar/95 & 21 & 166 & 158,6 & 1301,1 & 7.12 & $-0,24$ & & \\
\hline $21 /$ mar/95 & 15 & 181 & 104,8 & 1405,9 & 7,13 & $-0,01$ & & \\
\hline 11/abr/95 & 21 & 202 & 126,9 & 1532,8 & 7,15 & $-0,02$ & & \\
\hline 25/abr/95 & 14 & 216 & 39,2 & 1572 & 7,13 & 0,02 & & \\
\hline $25 /$ mai/95 & 30 & 246 & 61,4 & 1633,4 & 7,17 & $-0,04$ & & \\
\hline 26/fun/95 & 32 & 278 & 39 & 1672,4 & 7,18 & $-0,01$ & & \\
\hline $26 /$ jul/95 & 30 & 308 & 69.2 & 1741,6 & 6,94 & 0,24 & & \\
\hline 25/ago/95 & 30 & 338 & 21,7 & 1763,3 & 7,15 & $-0,21$ & & \\
\hline $22 /$ set/95 & 28 & 366 & 11,9 & 1775,2 & 7.27 & $-0,12$ & & \\
\hline 24/out/95 & 32 & 398 & 205,7 & 1980,9 & 6,92 & 0,35 & & \\
\hline
\end{tabular}

\begin{tabular}{|c|c|c|c|c|c|c|}
\hline 22/set/95 & - & 0 & - & - & 7,27 & \\
\hline $26 /$ set/95 & 4 & 4 & 21,8 & 21,8 & 7,15 & 0,12 \\
\hline $29 /$ set/95 & 3 & 7 & 1,4 & 23,2 & 7,16 & 0,01 \\
\hline $03 /$ out/95 & 5 & 12 & 0 & 23,2 & 7,18 & $-0,02$ \\
\hline $06 /$ out/95 & 3 & 15 & 7,6 & 38,8 & 7,14 & 0,04 \\
\hline $10 /$ out/95 & 4 & 19 & 9,9 & 40,7 & 7,16 & $-0,02$ \\
\hline $16 /$ out/95 & 6 & 25 & 27,1 & 67,8 & - & - \\
\hline $19 /$ out/95 & 3 & 28 & 20,1 & 87,9 & 6,8 & 0,36 \\
\hline $24 /$ out/95 & 5 & 33 & 31,3 & 119,2 & 6,92 & $-0,12$ \\
\hline $27 /$ out/95 & 4 & 37 & 0 & 119,2 & 6,98 & $-0,06$ \\
\hline $31 /$ out/95 & 4 & 41 & 22,6 & 141,8 & 6,92 & 0,06 \\
\hline $03 /$ nov/95 & 3 & 44 & 5,2 & 147 & 7,00 & $-0,08$ \\
\hline
\end{tabular}

POÇo PM-11 - Pça.Dr. Vicente (Pompéia)

\begin{tabular}{|c|c|c|c|c|c|c|c|c|}
\hline DATA & INTERVALO & No. DIAS & PRECIPITAÇÃo & PRECIPITAÇĀO & PROF. NIVEL & $\Delta \boldsymbol{h}$ & hmax - hmin & $\operatorname{\Sigma n}(+)$ \\
\hline $\begin{array}{l}\text { MEDIÇÃO } \\
\text { DO N.A. }\end{array}$ & (dias) & ACUMULADOS & $\begin{array}{c}\text { NO INTERVALO } \\
(\mathrm{mm})\end{array}$ & $\begin{array}{c}\text { ACUMULADA } \\
(\mathrm{mm})\end{array}$ & $\begin{array}{c}D^{\prime A G G U A} \times h \\
(m)\end{array}$ & (m) & (m) & (m) \\
\hline $21 / \mathrm{se} / 94$ & - & - & - & 0 & 6 & & \multirow{18}{*}{1,77} & \multirow{18}{*}{1} \\
\hline $24 /$ out/94 & 33 & 33 & 30,6 & 30,6 & 7,77 & $-1,77$ & & \\
\hline 22/now/94 & 29 & 62 & 131,6 & 162,2 & 7 & 0,77 & & \\
\hline $06 / \mathrm{dez} / 94$ & 14 & 76 & 102.3 & 264,5 & 7 & 0 & & \\
\hline 19/dez/94 & 13 & 89 & 118,9 & 352,8 & 7 & 0 & & \\
\hline $03 / \mathrm{jan} / 95$ & 15 & 104 & 157,9 & 541,3 & 7 & 0 & & \\
\hline 24/jar/95 & 21 & 125 & 148,4 & 689,7 & 7 & 0 & & \\
\hline $13 / \mathrm{fev} / 95$ & 20 & 145 & 452,8 & 1142,5 & 7,07 & $-0,07$ & & \\
\hline $06 / \mathrm{mar} / 95$ & 21 & 166 & 158,6 & 1301,1 & 7,09 & $-0,02$ & & \\
\hline $21 / \mathrm{mar} / 95$ & 15 & 181 & 104,8 & 1405,9 & 7,08 & 0,01 & & \\
\hline $11 / a b r / 95$ & 21 & 202 & 126.9 & 1532,8 & 7,08 & 0 & & \\
\hline 25/abr/95 & 14 & 216 & 39,2 & 1572 & 7,09 & $-0,01$ & & \\
\hline 25/maiv95 & 30 & 246 & 61,4 & 1633,4 & 7,09 & 0 & & \\
\hline 26/jun/95 & 32 & 278 & 39 & 1672,4 & 7,1 & $-0,01$ & & \\
\hline $26 / \mathrm{ju} / 95$ & 30 & 308 & 69,2 & 1741,6 & 6,88 & 0,22 & & \\
\hline 25/ago/95 & 30 & 338 & 21.7 & 1763,3 & 7,03 & $-0,15$ & & \\
\hline $22 / \mathrm{se} / 95$ & 28 & 366 & 11,9 & 1775,2 & 7,03 & 0 & & \\
\hline 27/out/95 & 32 & 398 & 205,7 & 1980,9 & 6,94 & 0,09 & & \\
\hline
\end{tabular}


POÇo PM-12 - Pça. Homero Silva (Pompéia)

\begin{tabular}{|c|c|c|c|c|c|c|c|c|}
\hline DATA & INTERVALO| & No. DIAS & PRECIPITAÇÃO & PRECIPITAÇĀO & PROF. NIVEL & $\Delta h$ & hmax - hmin & $\Sigma \mathrm{h}(+)$ \\
\hline $\begin{array}{l}\text { MEDIÇÄO } \\
\text { DO N.A. }\end{array}$ & (dias) & ACUMULADOS & $\begin{array}{c}\text { NO INTERVALO } \\
(\mathrm{mm})\end{array}$ & $\begin{array}{l}\text { ACUMULADA } \\
(\mathbf{m m})\end{array}$ & $\begin{array}{c}\text { D'ÁGUA - h } \\
(\mathrm{m})\end{array}$ & (m) & (m) & $(m)$ \\
\hline $22 /$ set $/ 94$ & - & - & - & 0 & 1,4 & & \multirow{18}{*}{0,63} & \multirow{18}{*}{0,93} \\
\hline $24 /$ out/94 & 32 & 32 & 30,6 & 30,6 & 1,44 & $-0,44$ & & \\
\hline 22/nov/94 & 29 & 61 & 131,6 & 162,2 & 1,35 & 0,09 & & \\
\hline $06 /$ dez/94 & 14 & 75 & 102,3 & 264,5 & 1,3 & 0,05 & & \\
\hline 19/dez/94 & 13 & 88 & 118,9 & 352,8 & 1,24 & 0,06 & & \\
\hline 03/jan/95 & 15 & 103 & 157,9 & 541,3 & 1,06 & 0,18 & & \\
\hline $24 / j a n / 95$ & 21 & 124 & 148,4 & 689,7 & 1,08 & $-0,02$ & & \\
\hline $13 / \mathrm{fev} / 95$ & 20 & 144 & 452,8 & 1142.5 & 0,63 & 0,45 & & \\
\hline $06 /$ mar/95 & 21 & 165 & 158,6 & 1301,1 & 0,75 & $-0,12$ & & \\
\hline $21 /$ mar/95 & 15 & 180 & 104,8 & 1405,9 & 0.85 & $-0,1$ & & \\
\hline 11/abr/95 & 21 & 201 & 126.9 & 1532,8 & 0,85 & 0 & & \\
\hline $25 / a b r / 95$ & 14 & 215 & 39,2 & 1572 & 0,75 & 0,1 & & \\
\hline 25/mai/95 & 30 & 245 & 61,4 & 1633,4 & 0,98 & $-0,23$ & & \\
\hline 26/jun/95 & 32 & 277 & 39 & 1672,4 & 1,03 & $-0,05$ & & \\
\hline $26 / j u l / 95$ & 30 & 307 & 69,2 & 1741,6 & 1,03 & 0 & & \\
\hline 25/ago/95 & 30 & 337 & 21,7 & 1763,3 & 1,12 & $-0,09$ & & \\
\hline $22 /$ set/95 & 28 & 365 & 11,9 & 1775,2 & 1,32 & -0.2 & & \\
\hline 24/out/95 & 32 & 398 & 205,7 & 1980,9 & 1,22 & 0,1 & & \\
\hline
\end{tabular}

MEDIDAS DE 4 EM 4 DIAS

\begin{tabular}{|c|c|c|c|c|c|c|}
\hline 22/set/95 & - & 0 & - & - & 1,32 & \\
\hline $26 /$ set/95 & 4 & 4 & 21,8 & 21,8 & - & \\
\hline $29 /$ set/95 & 3 & 7 & 1,4 & 23,2 & 1,23 & - \\
\hline $03 /$ out/95 & 5 & 12 & 0 & 23,2 & 1,23 & 0 \\
\hline $06 /$ out/95 & 3 & 15 & 7,6 & 38,8 & 1,24 & $-0,01$ \\
\hline $10 /$ out/95 & 4 & 19 & 9,9 & 40,7 & 1,26 & $-0,02$ \\
\hline $16 /$ out/95 & 6 & 25 & 27,1 & 67,8 & 1,18 & 0,08 \\
\hline $19 /$ out/95 & 3 & 28 & 20,1 & 87,9 & 1,21 & $-0,03$ \\
\hline $24 /$ out/95 & 5 & 33 & 31,3 & 119,2 & 1,22 & $-0,01$ \\
\hline $27 /$ out/95 & 4 & 37 & 0 & 119,2 & 1,23 & $-0,01$ \\
\hline $31 /$ out/95 & 4 & 41 & 22,6 & 141,8 & 1,09 & 0,14 \\
\hline $03 /$ nov/95 & 3 & 44 & 5,2 & 147 & 1,11 & $-0,02$ \\
\hline
\end{tabular}


POÇO PM-13 - EMEI (Pompéia)

\begin{tabular}{|c|c|c|c|c|c|c|c|c|}
\hline DATA & INTERVALO & | No. DIAS & PRECIPITAÇÃO & PRECIPITAÇĀO & PROF. NIVELI & $\Delta \mathbf{h}$ & hmax - hmin & $\Sigma h(t)$ \\
\hline $\begin{array}{l}\text { MEDIÇẢO } \\
\text { DO N.A. }\end{array}$ & (dias) & ACUMULADOS & $\begin{array}{c}\text { NO INTERVALO } \\
(\mathrm{mm})\end{array}$ & $\begin{array}{c}\text { ACUMULADA } \\
(\mathrm{mm})\end{array}$ & $\begin{array}{c}\text { D'AGUA - h } \\
(\mathrm{m})\end{array}$ & (m) & (m) & $(\mathbf{m})$ \\
\hline $23 / 09 / 94$ & - & - & - & 0 & 8,59 & & \multirow{18}{*}{2,02} & \multirow{18}{*}{2,02} \\
\hline $25 /$ out $/ 94$ & 32 & 32 & 32 & 32 & 8,64 & $-0,05$ & & \\
\hline 22/nov/94 & 28 & 60 & 130,2 & 162,2 & 8,58 & 0,06 & & \\
\hline $06 / d e z / 94$ & 14 & 74 & 102,3 & 264,5 & 8,47 & 0,11 & & \\
\hline 19/dez/94 & 13 & 87 & 118,9 & 383,4 & 8,22 & 0,25 & & \\
\hline 04/jan/95 & 15 & 102 & 174,3 & 557,7 & 7,85 & 0,37 & & \\
\hline 24/jan/95 & 21 & 123 & 132 & 689,7 & 7,66 & 0,19 & & \\
\hline $13 / \mathrm{fev} / 95$ & 20 & 143 & 452,8 & 1142.5 & 6,62 & 1,04 & & \\
\hline $06 /$ mar/95 & 21 & 164 & 158,6 & 1301,1 & 6,75 & $-0,13$ & & \\
\hline $21 / \operatorname{mar} / 95$ & 15 & 179 & 104,8 & 1405,9 & 6,94 & $-0,19$ & & \\
\hline 11/abr/95 & 21 & 200 & 126,9 & 1532,8 & 7,05 & $-0,11$ & & \\
\hline 25/abr/95 & 14 & 214 & 39,2 & 1572 & 7,24 & $-0,19$ & & \\
\hline $25 / \mathrm{mai} / 95$ & 30 & 244 & 61,4 & 1633,4 & 7,62 & $-0,38$ & & \\
\hline 26/jun/95 & 32 & 276 & 39 & 1672,4 & 7,94 & $-0,32$ & & \\
\hline $26 \sqrt{j} u / / 95$ & 30 & 306 & 69,2 & 1741,6 & 7,97 & $-0,03$ & & \\
\hline 25/ago/95 & 30 & 336 & 21,7 & 1763,3 & 8,28 & $-0,31$ & & \\
\hline $22 /$ set/95 & 28 & 364 & 11,9 & 1775,2 & 8,49 & $-0,21$ & & \\
\hline 24/out/95 & 32 & 398 & 205,7 & 1980,9 & 8,18 & 0,31 & & \\
\hline
\end{tabular}

\begin{tabular}{|c|c|c|c|c|c|c|}
\hline \multicolumn{7}{|c|}{ MEDIDAS DE 4 EM 4 DIAS } \\
\hline $22 /$ set/95 & - & 0 & - & - & 8,49 & \\
\hline $26 /$ set/95 & 4 & 4 & 21,8 & 21,8 & 8,55 & $-0,05$ \\
\hline 29/set/95 & 3 & 7 & 1,4 & 23,2 & 8,57 & $-0,02$ \\
\hline 03/ous/95 & 5 & 12 & 0 & 23,2 & 8,57 & 0 \\
\hline $06 /$ out/95 & 3 & 15 & 7,6 & 38,8 & 8,57 & 0 \\
\hline 10/out/95 & 4 & 19 & 9,9 & 40,7 & 8,59 & $-0,02$ \\
\hline 16/out/95 & 6 & 25 & 27,1 & 67,8 & 8,52 & 0,07 \\
\hline 19/out/95 & 3 & 28 & 20,1 & 87,9 & 8,22 & 0,3 \\
\hline 24/out/95 & 5 & 33 & 31,3 & 119,2 & 8,18 & 0,04 \\
\hline 27/out/95 & 4 & 37 & 0 & 119,2 & 8,13 & 0,05 \\
\hline $31 /$ out $/ 95$ & 4 & 41 & 22,6 & 141,8 & 8,13 & 0 \\
\hline 03/nov/95 & 3 & 44 & 5,2 & 147 & 8,11 & 0,02 \\
\hline
\end{tabular}




\section{ANEXO 4:}

Gráficos: Precipitação - oscilação do nível freático nos poços de monitoramento $1,2,3,4,5,6,7,8,9,10$, 12, 13, Figuras 1 a 12, respectivamente (leituras quinzenais-mensais) 


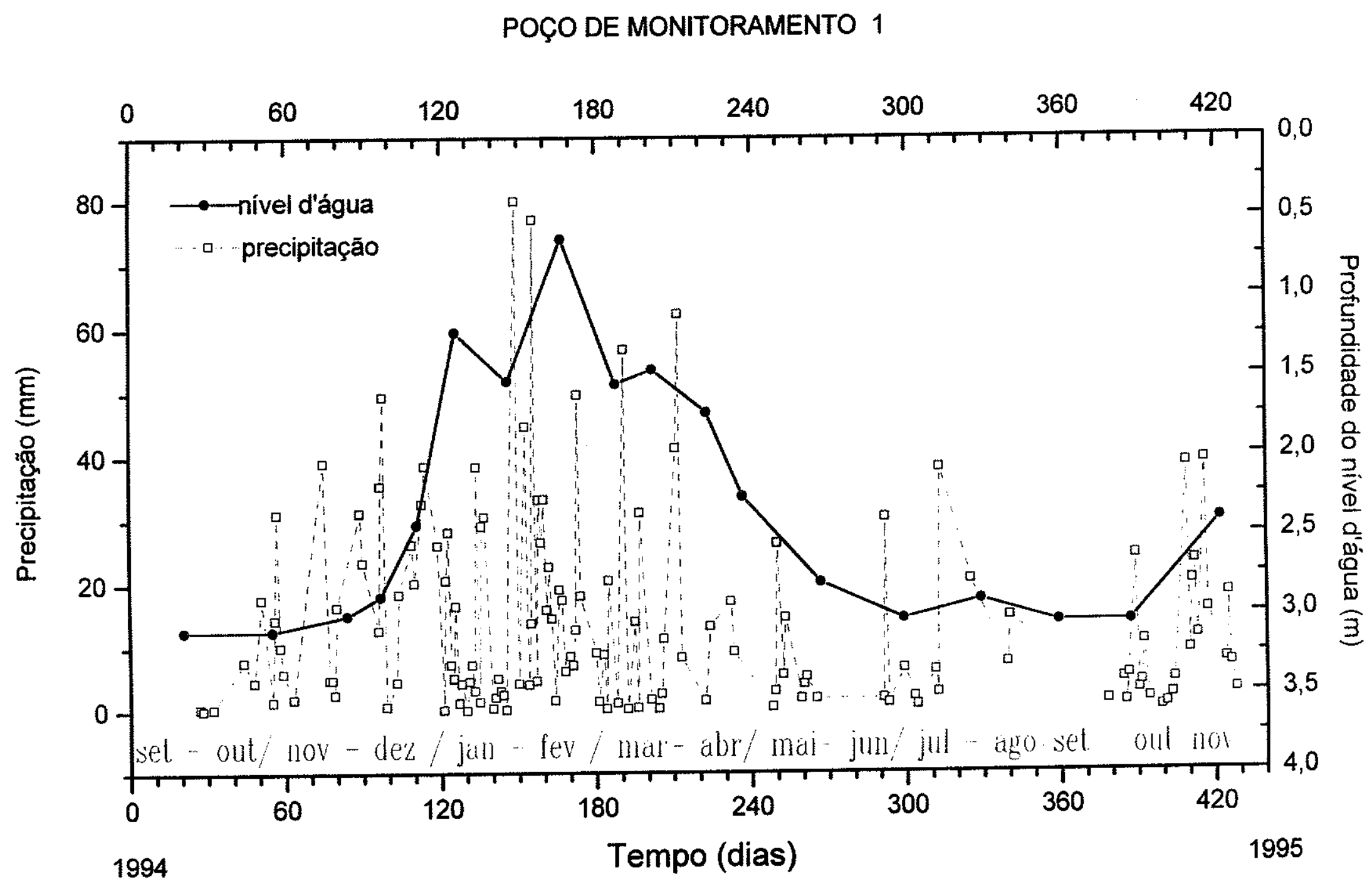

FIGURA 1 - Precipitação - Oscilação do nivel freático em terreno quaternário 


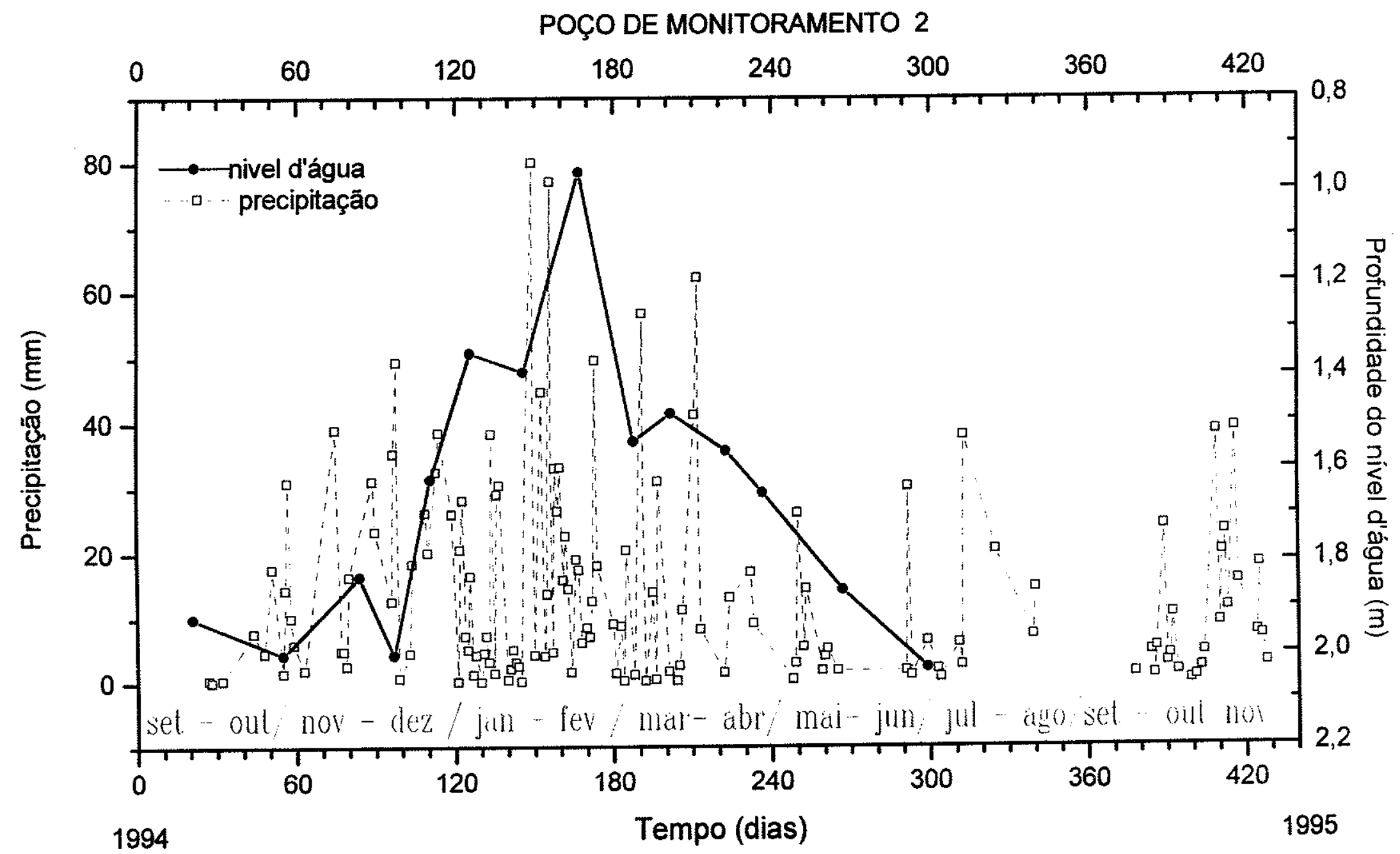

FIGURA 2 - Precipitação - Oscilação do nível freático em terreno quaternário 


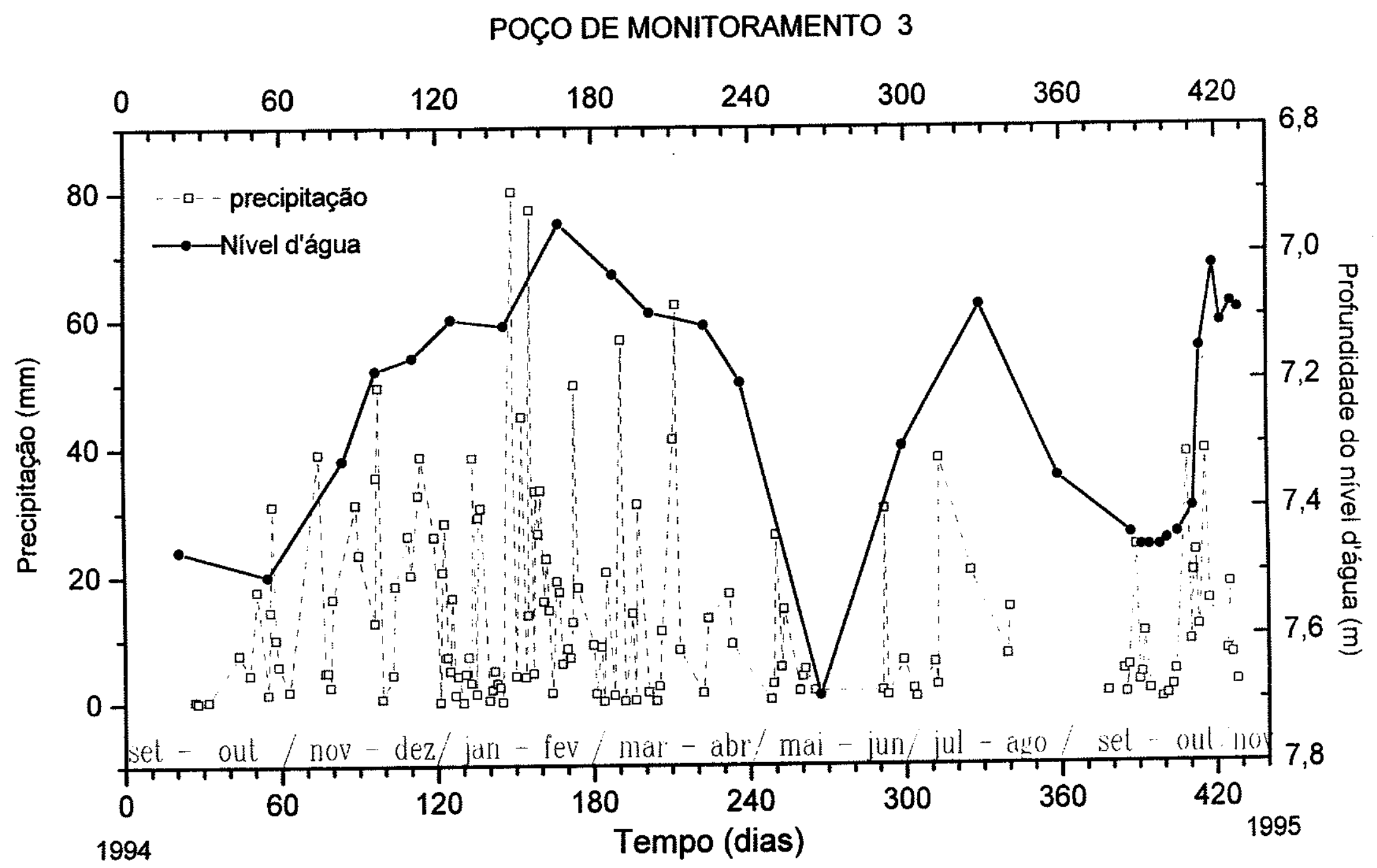

FIGURA 3 - Precipitação - Oscilação do nivel freático em terreno terciário 


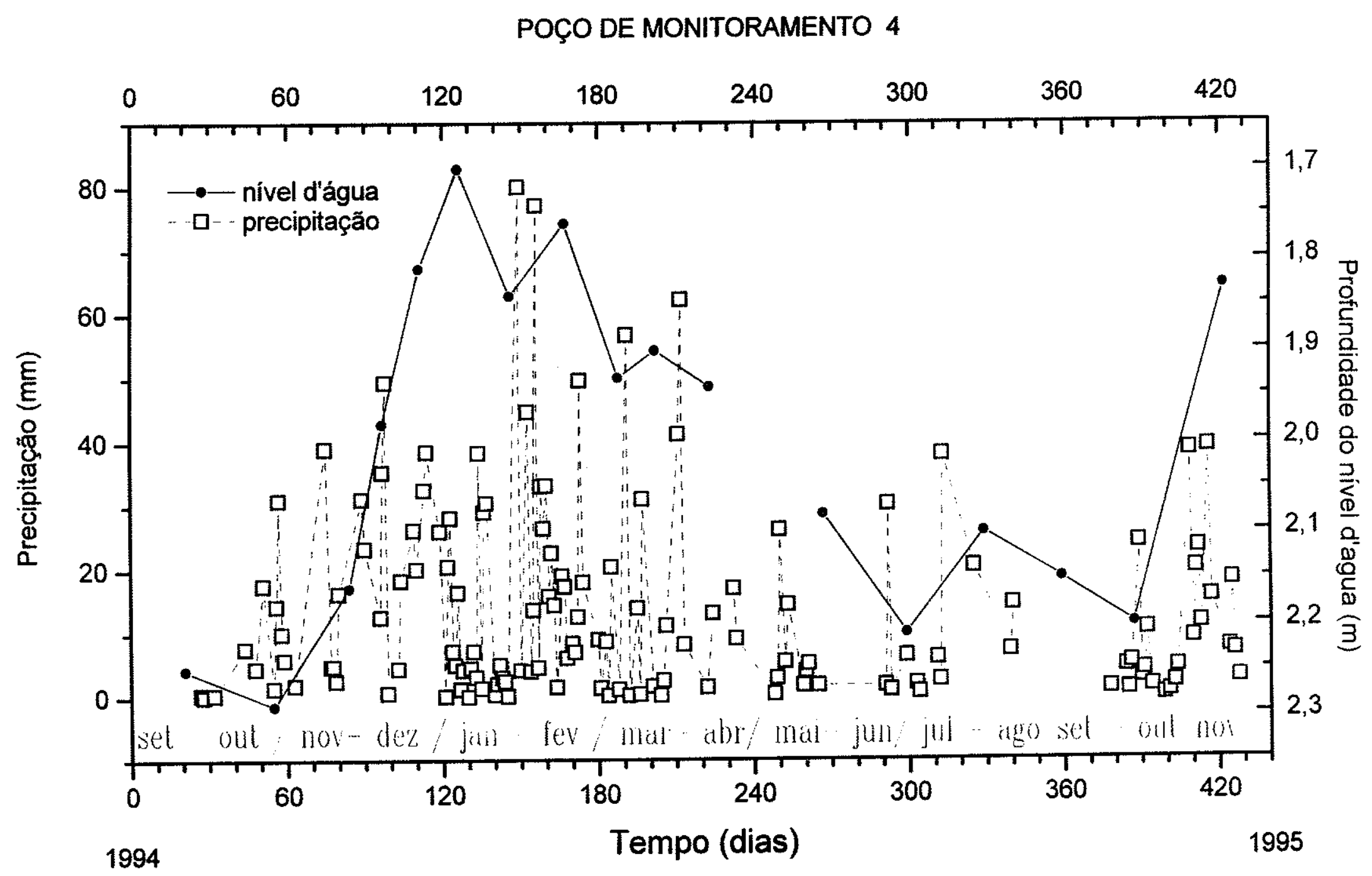

FIGURA 4 - Precipitação - Oscilação do nível freático em terreno quaternário 


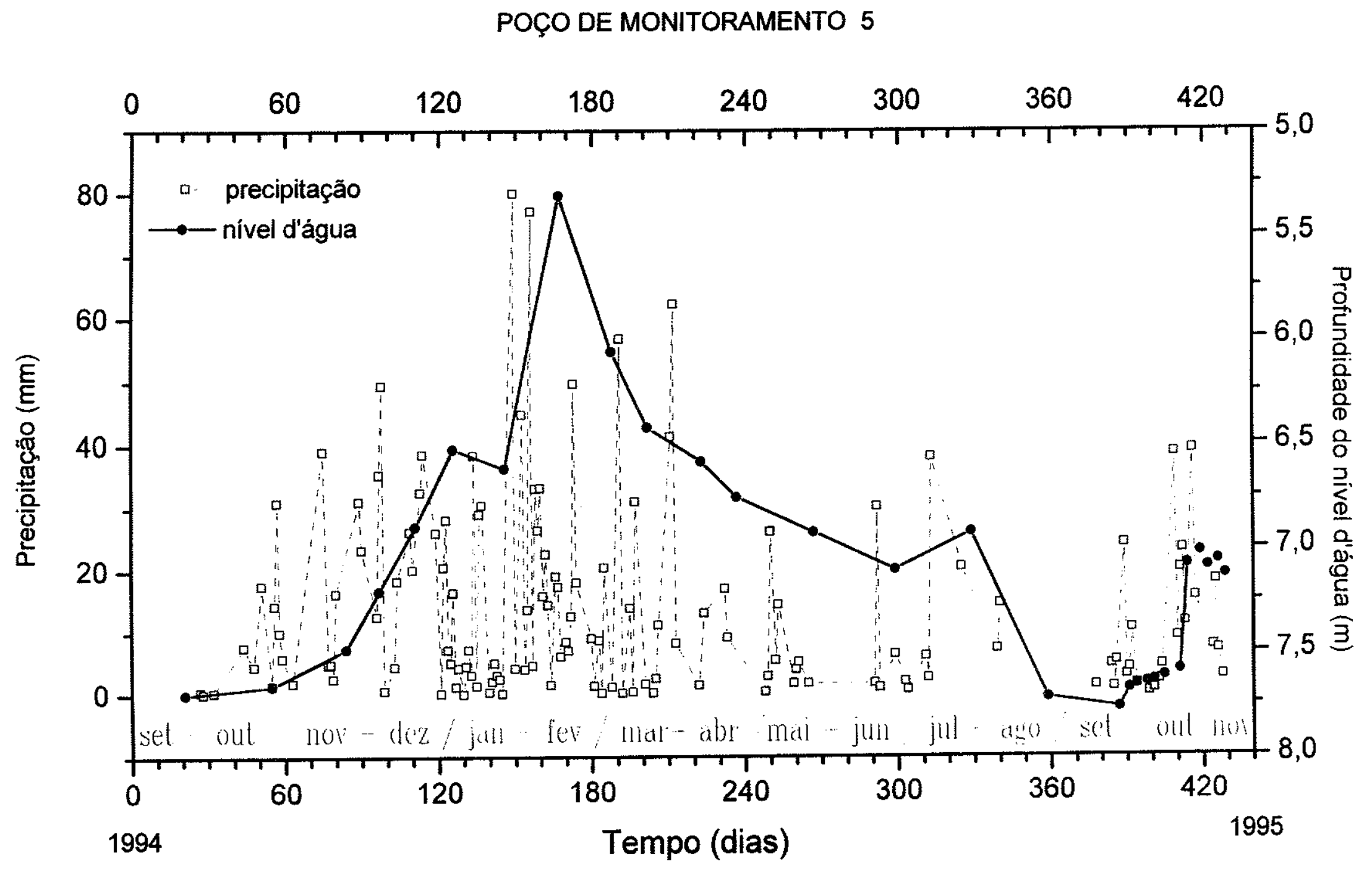

FIGURA 5 - Precipitação - Oscilação do nivel freático em terreno terciário 


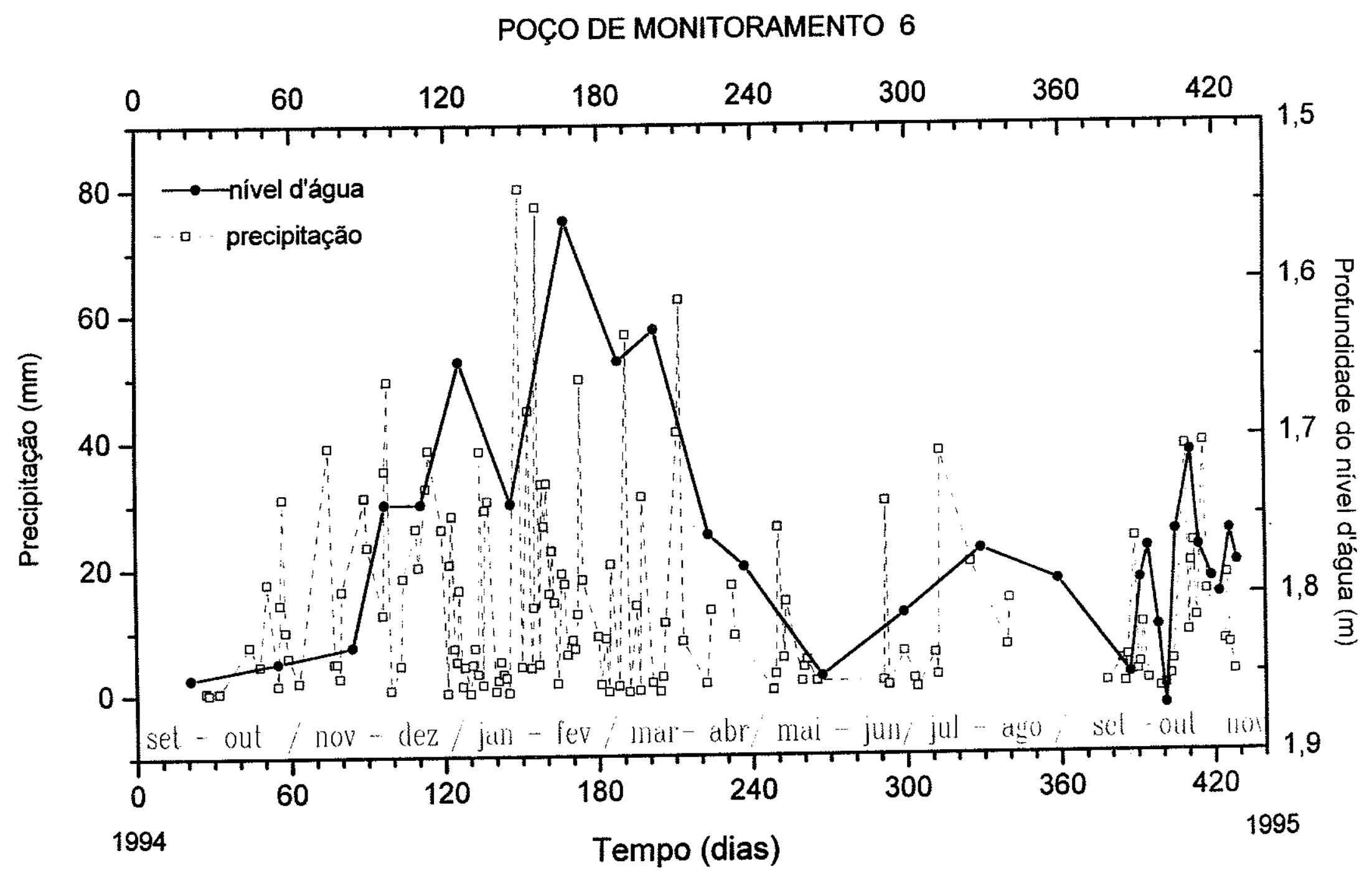

FIGURA 6 - Precipitação - Oscilação do nivel freático em terreno terciário 


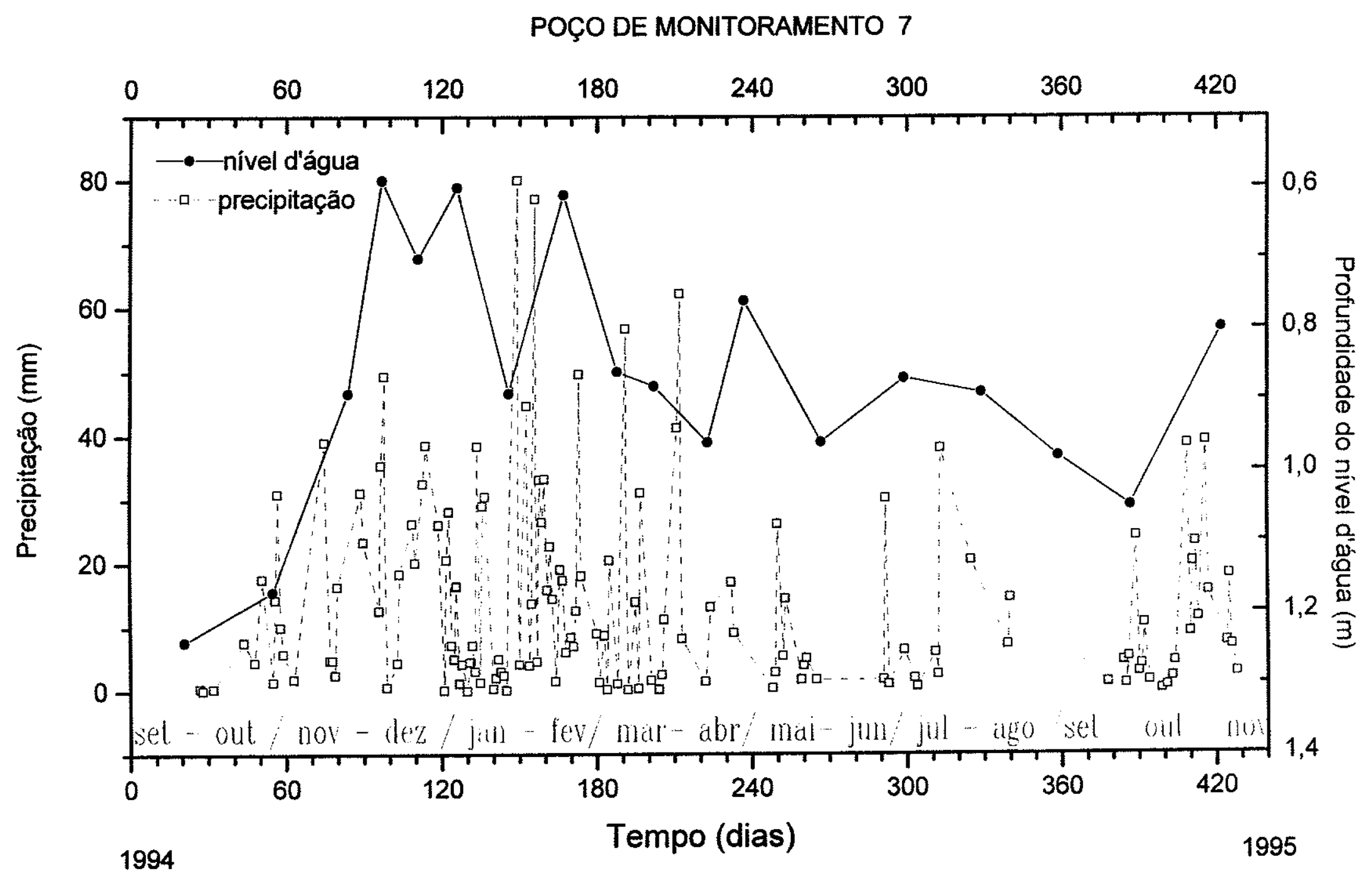

FIGURA 7 - Precipitação - Oscilação do nivel freático em terreno quaternário 


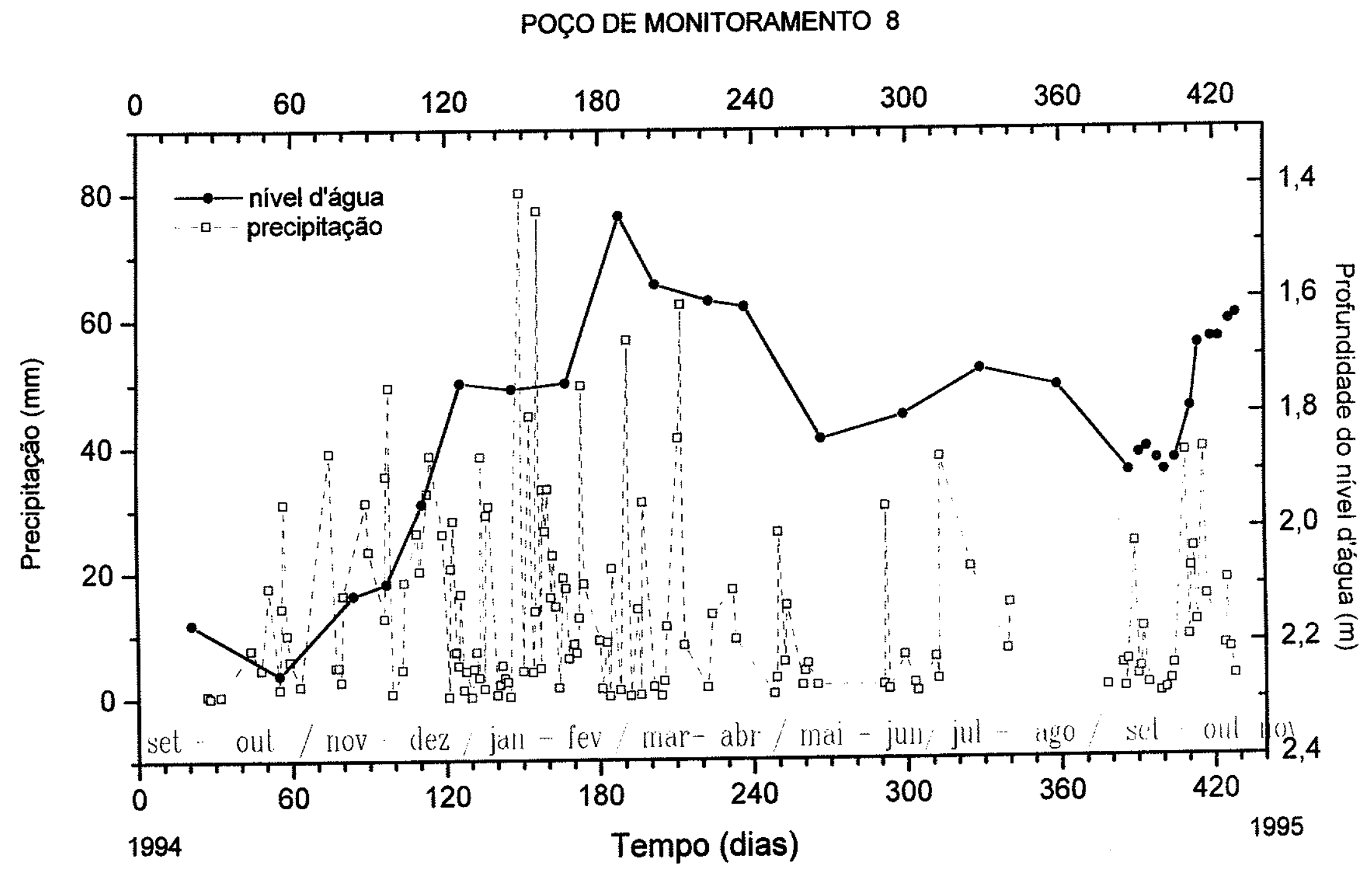

FIGURA 8 - Precipitação - Oscilação do nível freático em terreno terciário 


\section{POÇO DE MONITORAMENTO 9}

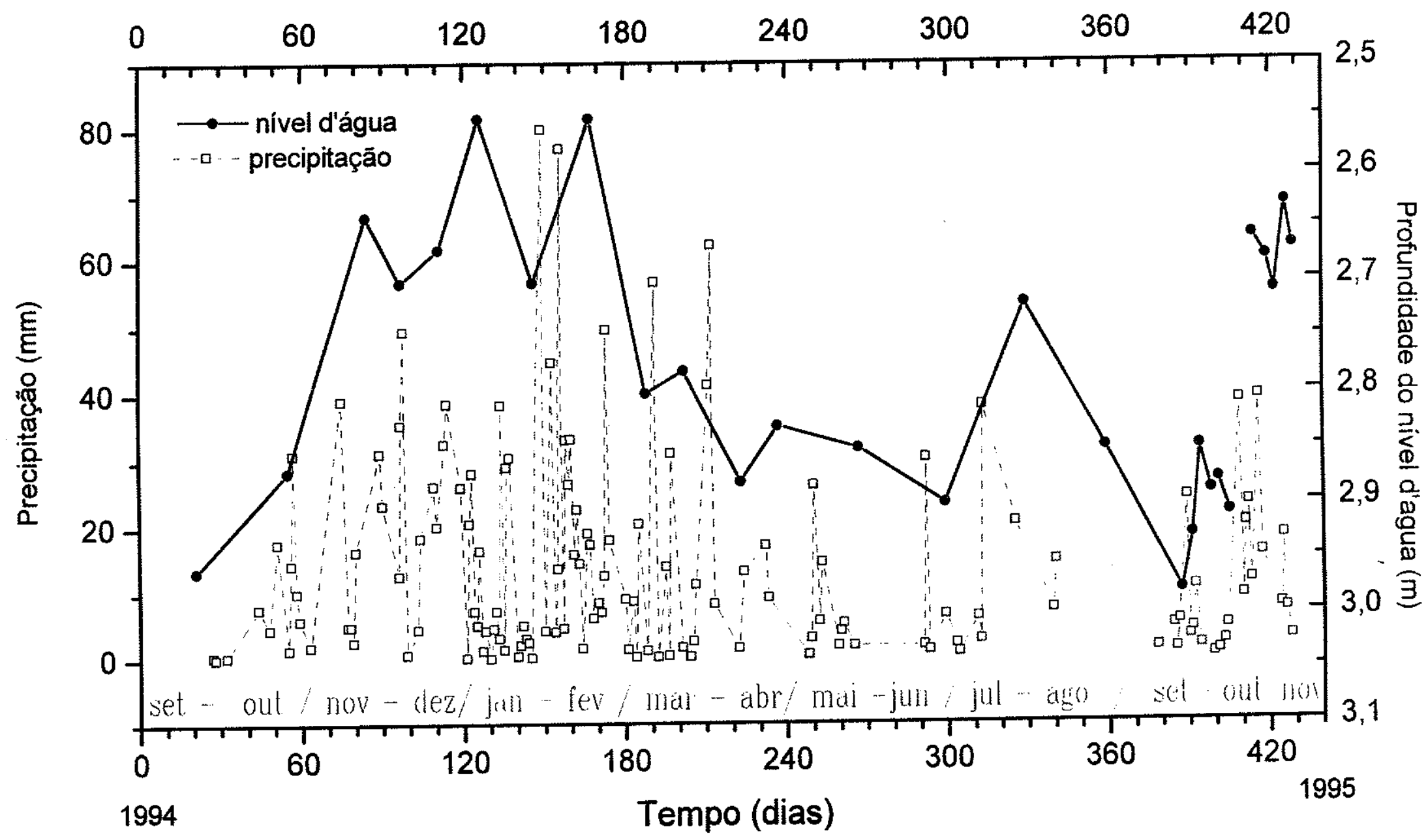

FIGURA 9 - Precipitação - Oscilação do nivel freático em terreno terciário 


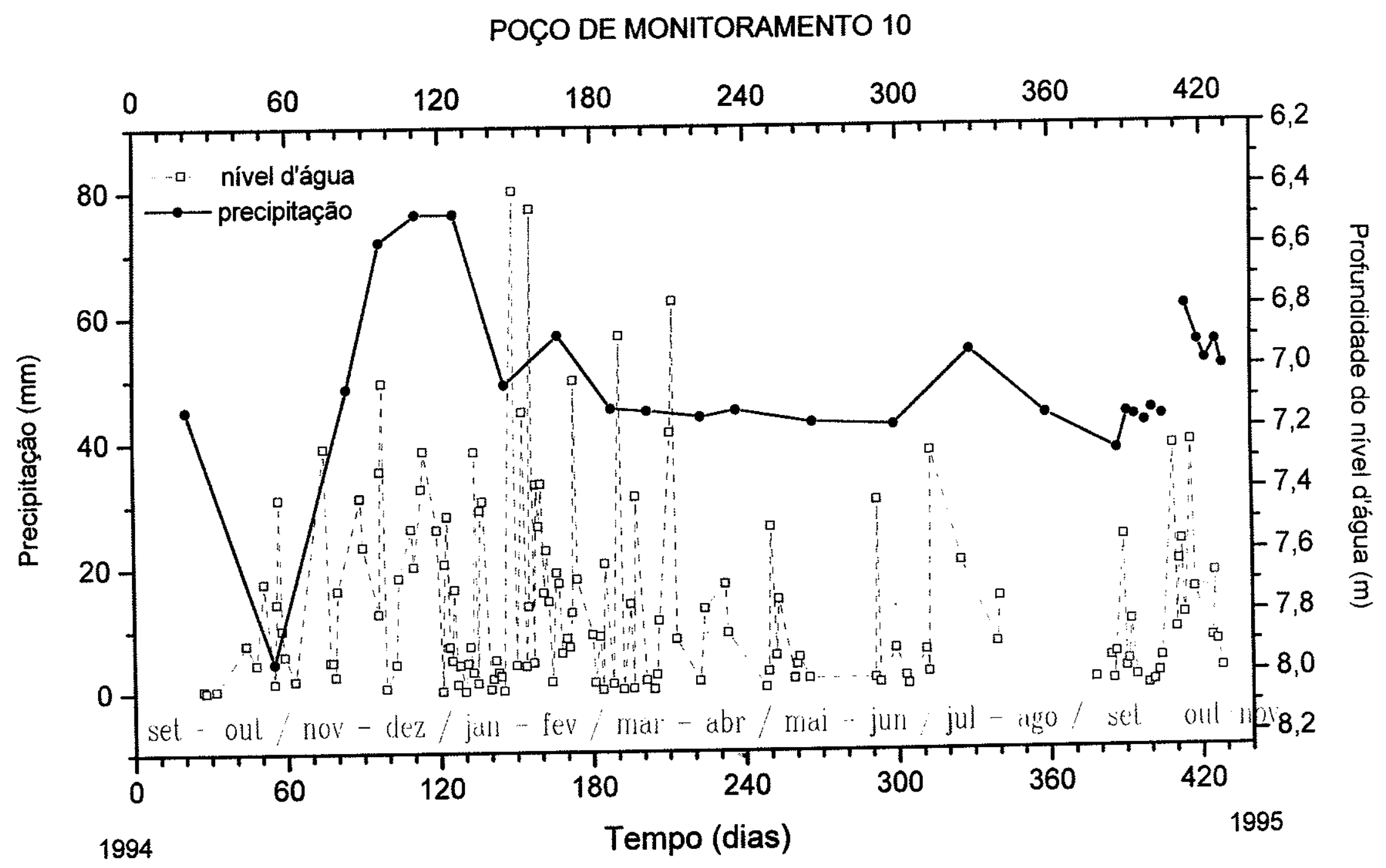

FIGURA 10 - Precipitação - Oscilação do nivel freático em terreno terciário 


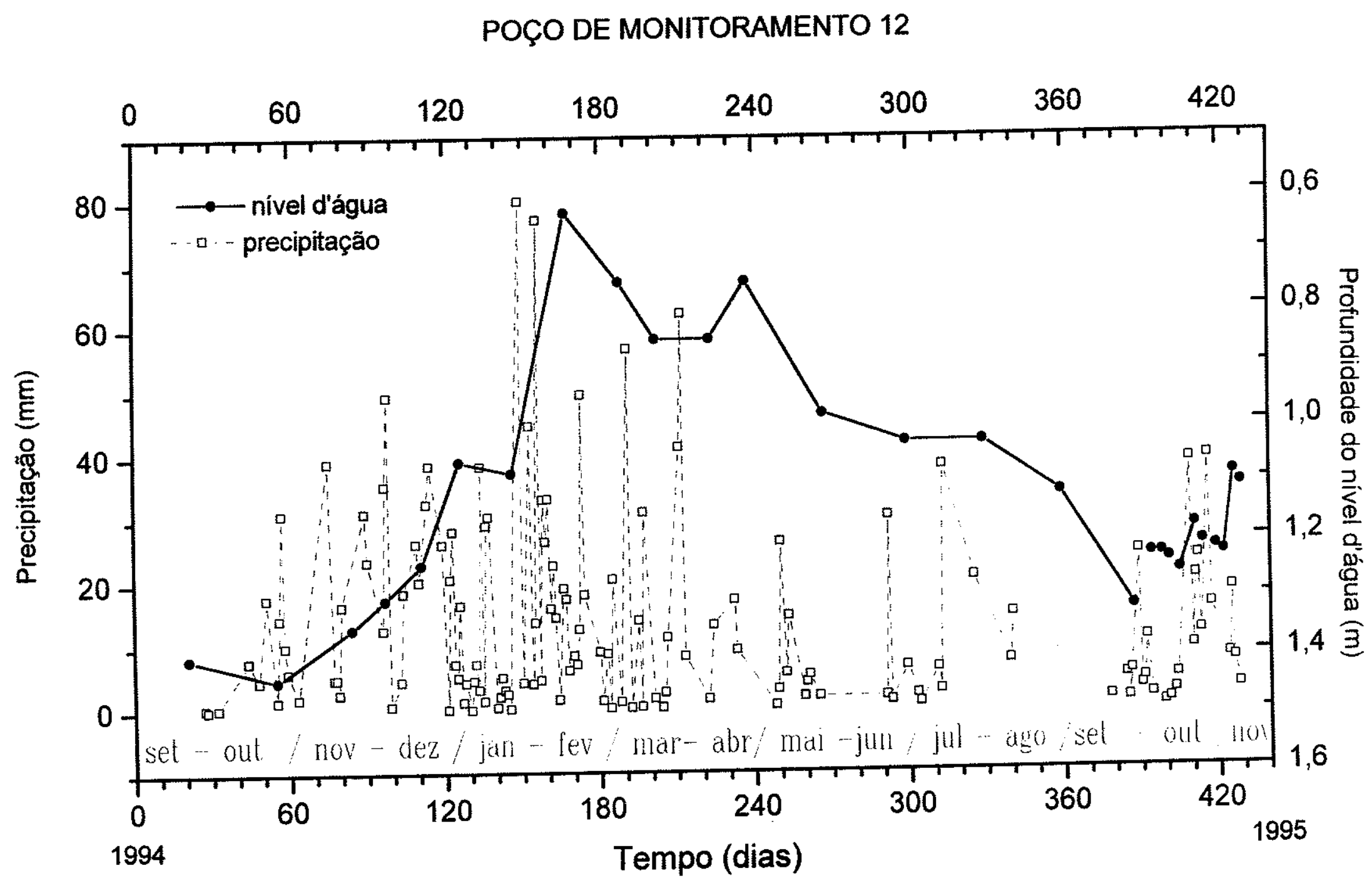

FIGURA 11 - Precipitação - Oscilação do nível freático em terreno terciário 
POÇO DE MONITORAMENTO 13

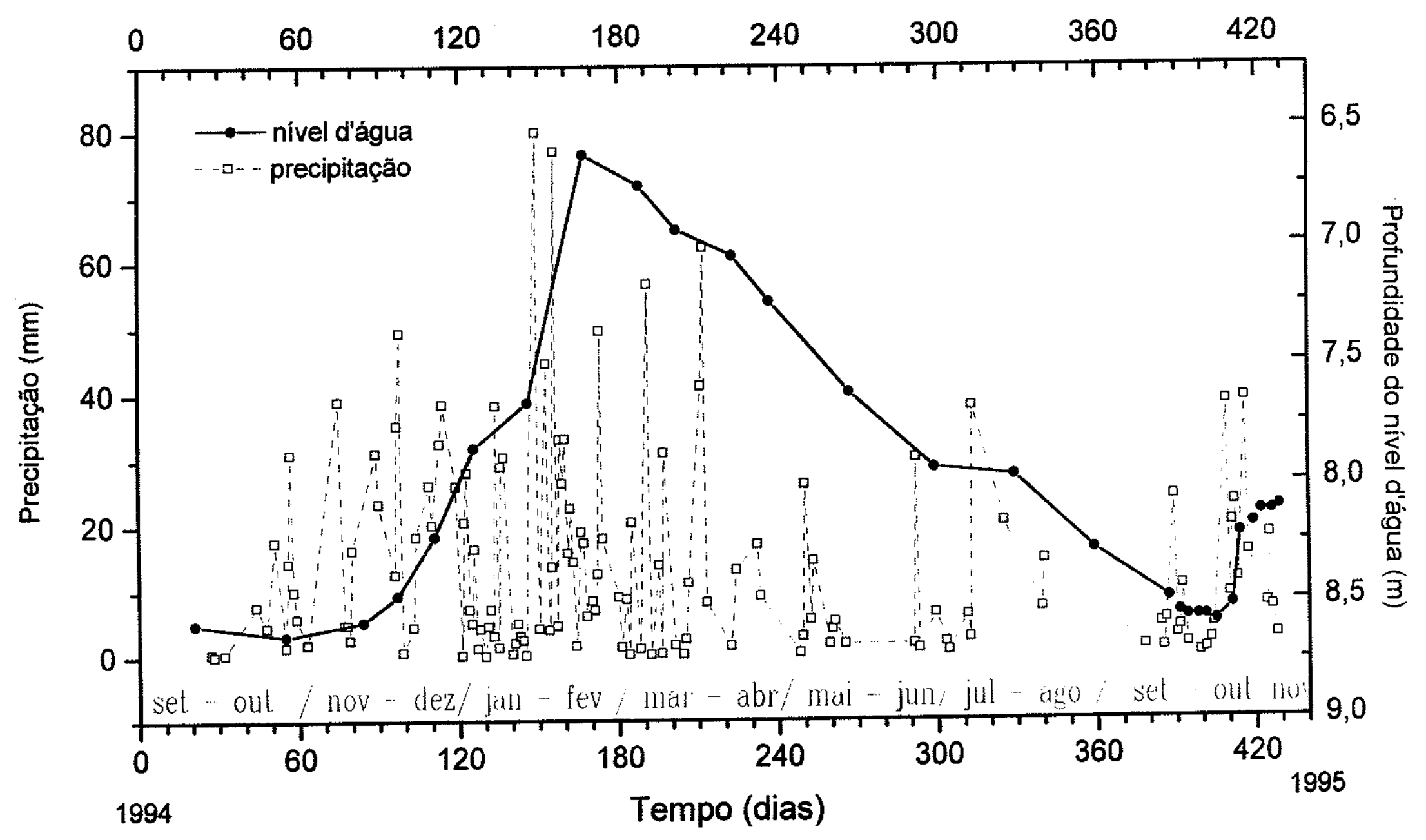

FIGURA 12 - Precipitção - Oscilação do nivel freático em terreno terciário 


\section{ANEXO 5:}

Gráficos: Precipitação oscilação do nível freático nos poços de monitoramento do terreno terciário $3,5,6,8$, $9,10,12$ e 13. 
POÇO DE MONITORAMENTO PM - 03
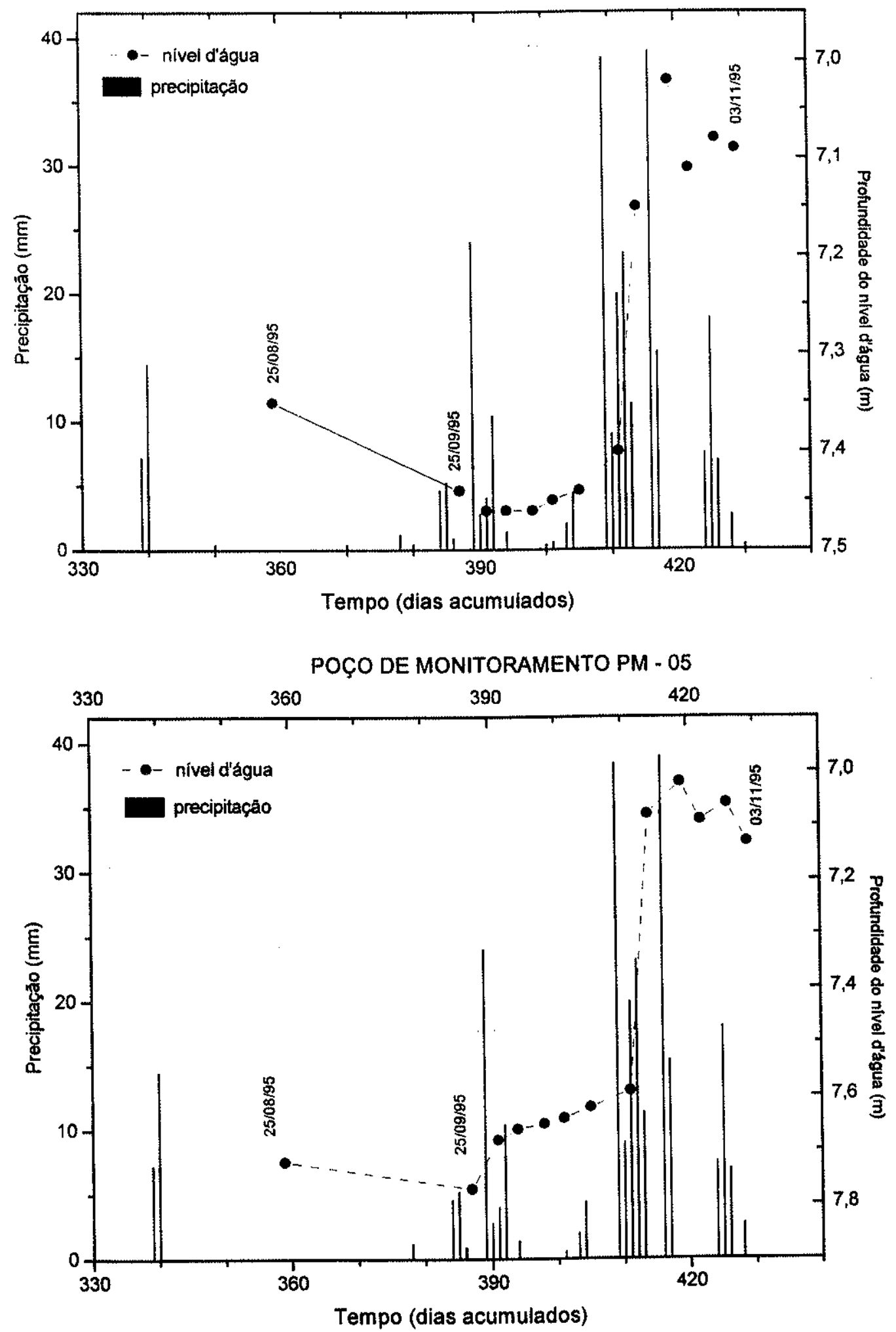

VARIAÇOES DO NIVEL FREÁTICO NOS POÇOS DE MONITORAMENTO MAIS PROFUNDOS DO TERRENO TERCIÁRIO PERIODO DE MEDIÇÃO: 44 DIAS INTERVALO: 4 DIAS 

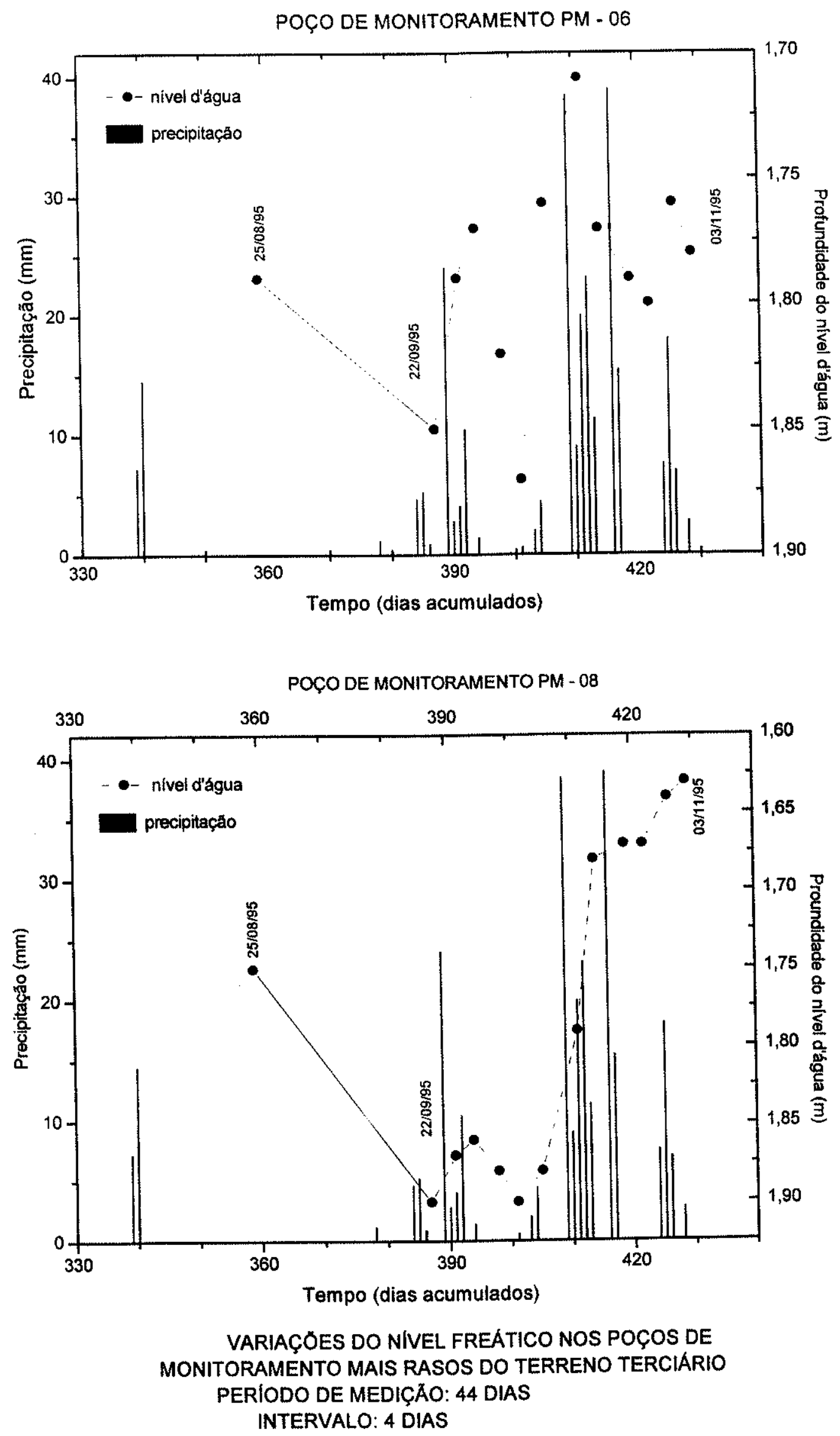

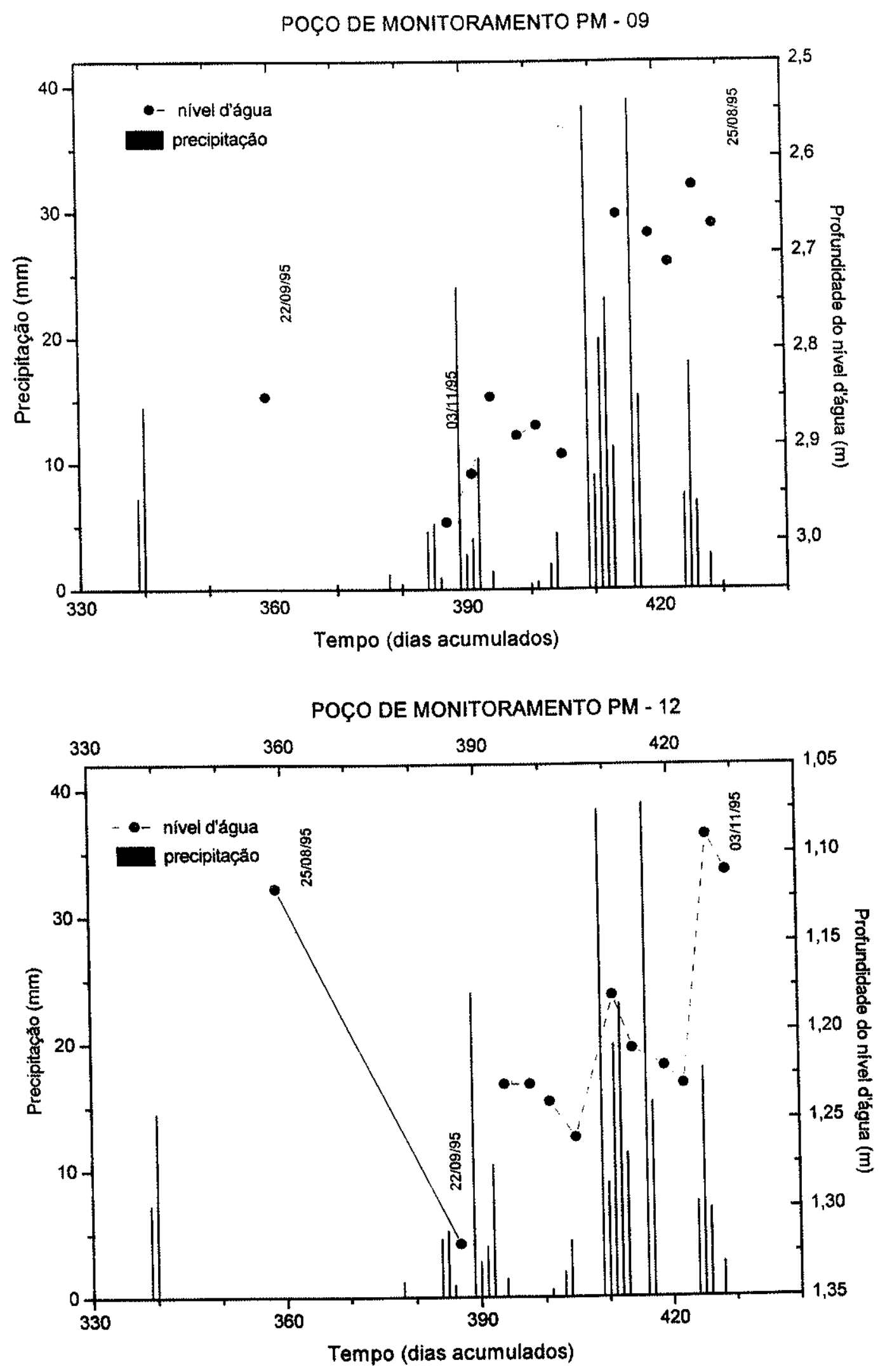

VARIAÇŐES DO NIVEL FREATICO NOS POÇOS DE MONITORAMENTO MAIS RASOS DO TERRENO TERCIÁRIO PERIODO DE MEDIÇÃO: 44 DIAS INTERVALO: 4 DIAS 
POÇO DE MONITORAMENTO PM -10

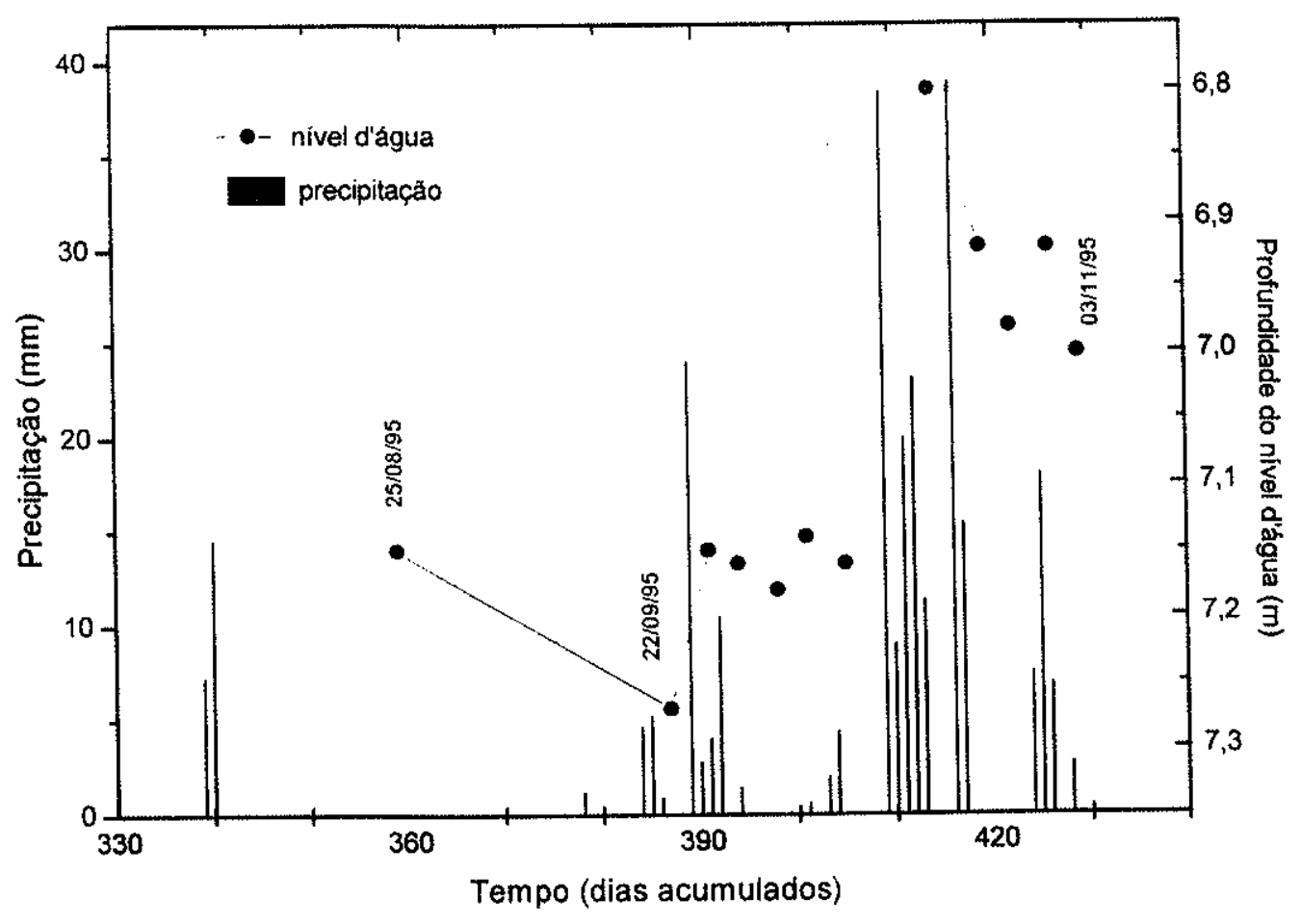

POÇO DE MONITORAMENTO PM -13

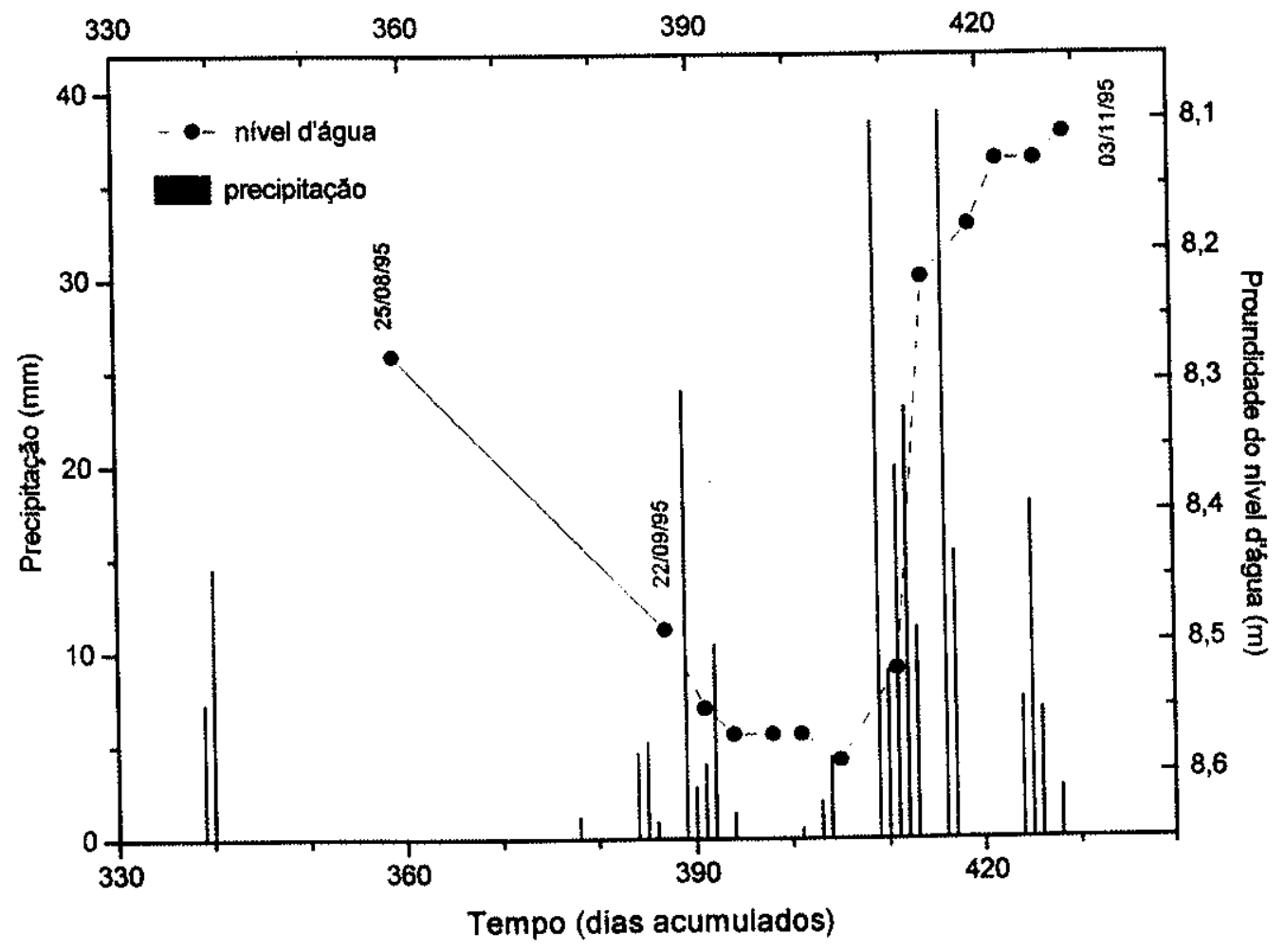

VARIAÇŐES DO NIVEL FEÁTICO NOS POÇOS DE MONITORAMENTO MAIS PROFUNDOS DO TERRENO

TERCIÁRIO

PERIODO DE MEDIÇÃO: 44 DIAS

INTERVALO: 4 DIAS 


\section{ANEXO 6:}

Planilhas:

Tabela 1 - Dados pluviométricos do Posto Água Branca.

Tabela 2 - Resultados das análise químicas nos poços de monitoramento

Tabela 3 - Resultados das análises químicas nas nascentes. 
TABELA 1 - Pluviometria diária - Posto Água Branca

LAT: $23^{\circ} 31^{\prime} \quad$ LONG: $46^{\circ} 41^{\circ}$

\begin{tabular}{|c|c|c|c|c|c|c|c|c|c|c|c|c|c|c|c|}
\hline \multirow{2}{*}{$\begin{array}{l}\text { ANO } \\
\text { DIAS }\end{array}$} & \multicolumn{5}{|c|}{1994} & \multicolumn{10}{|c|}{1996} \\
\hline & ASO & SET & OUT & NOV & DEZ & JAN & FEV & MAR & ABR & MAL & JUN & JUL & $A G O$ & SET & OUT \\
\hline & & & & & & & & & & & & & & & \\
\hline 1 & 0 & 0 & 0 & 0 & 0 & 28.1 & 4 & 0 & 8,2 & 0 & 0 & 0.6 & 0 & 0 & 0 \\
\hline 2 & 0 & 0 & 0,3 & 1.8 & 0 & 7,2 & 13,7 & 8,7 & 0 & 0 & 0 & 0 & 0 & 0 & 0 \\
\hline 3 & 0 & 0 & 0 & 0 & 0 & 5 & 77,1 & 0.2 & 0 & 0 & 0 & 0 & 0 & 0 & 0 \\
\hline 4 & 0 & 0 & 0 & 0 & 0 & 16,4 & 4,6 & 20.4 & 0 & 0 & 0 & 0 & 0 & 0 & 0,1 \\
\hline 5 & 0 & 0 & 0 & 0 & 12,6 & 1,2 & 33,1 & 0 & 0 & 0 & 0 & 0 & 7,2 & 0 & 0 \\
\hline 6 & 0 & 0 & 0 & 0 & 35,3 & 4,2 & 26,4 & 0 & 0 & 0,3 & 0 & 0 & 14,5 & 0 & 0,6 \\
\hline 7 & 0 & 0 & 0 & 0 & 49,3 & 0 & 33,2 & 1,1 & 0 & 2,8 & 0 & 0 & 0 & 0 & 0 \\
\hline 8 & 0 & 0 & 0 & 0 & 0,6 & 0 & 15,8 & 0 & 0 & 26,1 & 0 & 6 & 0 & 0 & 2 \\
\hline 9 & 0 & 0 & 0 & 0 & 0 & 4,5 & 22,6 & 0 & 0 & 0 & 0 & 2,5 & 0 & 0 & 4,4 \\
\hline 10 & 0 & 0 & 0 & 0 & 0 & 7,2 & 14,4 & 56,7 & 1,4 & 5,4 & 0 & 37,9 & 0 & 0 & 0 \\
\hline 11 & 0 & 0 & 0 & 0 & 0 & 3,1 & 1,5 & 0 & 0 & 14,4 & 0 & 0 & 0 & 0 & 0 \\
\hline 12 & 0 & 0 & 0 & 0 & 4,4 & 38,3 & 0 & 0,2 & 13,1 & 0 & 0 & 0 & 0 & 0 & 0 \\
\hline 13 & 0 & 0 & 0 & 0 & 18,3 & 1,3 & 19 & 0 & 0 & 0 & 0 & 0 & 0 & 1,2 & 0 \\
\hline 14 & 0 & 0 & 7,7 & 39 & 0 & 29 & 17,3 & 13,9 & 0 & 0 & 0 & 0 & 0 & 0 & 38,4 \\
\hline 15 & 0 & 0 & 0 & 0 & 0 & 30,4 & 6,1 & 0,3 & 0 & 0 & 0 & 0 & 0 & 0 & 9 \\
\hline 16 & 0 & 0 & 0 & 4,8 & 0 & 0 & 0 & 31 & 0 & 0 & 0 & 0 & 0 & 0 & 19,9 \\
\hline 17 & 0 & 0 & 0 & 4,8 & 0 & 0 & 8,4 & 0 & 0 & 1,7 & 0 & 0 & 0 & 0 & 23,1 \\
\hline 18 & 0 & 0 & 4,5 & 2,5 & 26,2 & 0,3 & 7 & 0 & 0 & 3,9 & 1,7 & 0 & 0 & 4,6 & 11,3 \\
\hline 19 & 0 & 0 & 0 & 16,3 & 20,1 & 2 & 12,6 & 0 & 0 & 5,1 & 30,1 & 0 & 0 & 0 & 0 \\
\hline 20 & 0 & 0 & 0 & 0 & 0 & 5 & 49,6 & 1,6 & 17 & 0 & 0.9 & 0 & 0 & 5,2 & 0 \\
\hline 21 & 0 & 0 & 17,6 & 0 & 0 & 3 & 18 & 0 & 9,1 & 0 & 0 & 0 & 0 & 0,9 & 38,9 \\
\hline 22 & 0 & 0 & 0 & 0 & 32,5 & 2.4 & 0 & 0 & 0 & 0 & 0 & 20,3 & 0 & 0 & 15,4 \\
\hline 23 & 0 & 0 & 0 & 0 & 38,5 & 0,1 & 0 & 0,2 & 0 & 1,7 & 0 & 0 & 0 & 0 & 0 \\
\hline 24 & 0 & 0 & 0 & 0 & 0 & 0 & 0 & 2,5 & 0 & 0 & 0 & 0 & 0 & 24 & 0 \\
\hline 25 & 0 & 0 & 1.4 & 0 & 0 & 0 & 0 & 11,2 & 0 & 0 & 0 & 0 & 0 & 2,8 & 0 \\
\hline 26 & 0 & 0 & 14,3 & 0 & 0 & 0 & 0 & 0 & 0 & 0 & 6,3 & 0 & 0 & 4 & 0 \\
\hline 27 & 0 & 0,4 & 30,9 & 0 & 0 & 138,5 & 9 & 0 & 0 & 0 & 0 & 0 & 0 & 10,4 & 0 \\
\hline 28 & 0 & 0,1 & 10 & 31,1 & 26 & 4,2 & 1,3 & 0 & 0 & 0 & 0 & 0 & 0 & 0 & 0 \\
\hline 29 & 0 & 0 & 5,8 & 23,3 & 0 & 0 & & 0 & 0 & 0 & 0 & 0 & 0 & 1,4 & 7,5 \\
\hline 30 & 0 & 0 & 0 & 0 & 0.1 & 0 & & 41,2 & 0 & 0 & 1,9 & 0 & 0 & 0 & 18 \\
\hline 31 & 0 & & 0 & & 20,5 & 44,7 & & 62,2 & & 0 & & 0 & 0 & & 6,9 \\
\hline & & & & & & & & & & & & & & & \\
\hline TOTAL & 0 & 0,5 & 92,5 & 123,6 & 284,4 & 376,1 & 394,7 & 251,4 & 48,8 & 61,4 & 40,9 & 67,3 & 21,7 & 54,5 & 195,5 \\
\hline MÁXIMA & 0 & 0,4 & 30,9 & 39 & 49,3 & 138,5 & 77,1 & 62,2 & 17 & 26,1 & 30,1 & 37,9 & 14,5 & 24 & 38,9 \\
\hline MÉDIA & 0 & 0,02 & 2,98 & 4,12 & 9,17 & 12,13 & 14,1 & 8.11 & 1,62 & 1,98 & 1,36 & 2,17 & 0,70 & 1,82 & 6,31 \\
\hline
\end{tabular}


Tabela 2 - Resultados das Análises Químicas nos Poços de Monitoramento

\begin{tabular}{|c|c|c|c|c|c|c|c|c|c|c|c|c|c|c|c|c|}
\hline DATA DA & POÇO & Cl & F (total) & N (Nitrato) & 504 & $\mathrm{HCO} 3$ & $\mathrm{Ca}$ & $\mathrm{Mg}$ & $\mathrm{Na}$ & K & $\mathrm{Fe}$ & Mn & A) & $\mathbf{2 n}$ & $\mathrm{cou}$ & 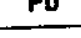 \\
\hline COLETA & & & & & (total) & $(\mathrm{CaCO})$ & & & & & (total) & & & & & \\
\hline $25 /$ out/94 & 01 - Limáo & 9,5 & 0,5 & 0,27 & $<2$ & 525 & 47,7 & 88,5 & 14,6 & 54 & 10,2 & 0,3 & 3,4 & 0,1 & $<0,1$ & $<0,1$ \\
\hline $25 /$ out/94 & 02 -P. Martins & 47,5 & 0,23 & 0,41 & 8 & 15 & 8,8 & 3,2 & 56,4 & 3,6 & 15,5 & 0,3 & 1,5 & 0,1 & $<0,1$ & $<0,1$ \\
\hline $25 /$ out/94 & 03 - Fco Matarazo & 21 & 0.42 & 17,79 & 3 & 27 & 7,2 & 2,2 & 8,5 & 2,7 & 0,1 & $\overline{0,1}$ & $\overline{3,4}$ & $<0,1$ & $<0,1$ & $<0,1$ \\
\hline $25 /$ out/94 & 04 - Várzea & 12,5 & 0,23 & 0,10 & 8 & 184 & 38 & 30 & 11,6 & 15,5 & 10 & 0,1 & 96 & 0,1 & $<0,1$ & 0,1 \\
\hline $25 /$ out 194 & 05 - Comélia & 12,5 & 0,53 & 0,17 & 3 & 58 & 5,7 & 4,8 & 13,6 & 6,5 & 42,8 & 0,3 & 13,7 & 0,2 & $<0,1$ & 0,1 \\
\hline $25 /$ out/94 & 06-A. Branca & 28,5 & 0,23 & 12,54 & 9 & 45 & 6,7 & 6,4 & 58,6 & 6,3 & 0,2 & 0,1 & 0,5 & $<0,1$ & $<0,1$ & $<0,1$ \\
\hline 25 /out $/ 94$ & 07-Nacional & 47,5 & 0,12 & 0,14 & 3 & 9 & 14 & 17 & 34,2 & 9 & 14,3 & 0,1 & 0,3 & $<0,1$ & $<0,1$ & n.d. \\
\hline $24 /$ out/94 & $08-J$. Bandeira & 21,5 & 0,15 & 22,58 & 13 & 25 & 6,4 & 3,2 & 11 & 3,8 & 1,2 & 0,2 & 2,4 & 0,1 & $<0,1$ & 0,1 \\
\hline $25 /$ out/94 & $09-1$ Kaman & 10,5 & 0,81 & 2,02 & 6 & 55 & 9,5 & 4,5 & 6,5 & 3,6 & 5,3 & 0,3 & 2,8 & $<0,1$ & $<0,1$ & $<0,1$ \\
\hline $24 / 10 / 94$ & 10 - 0 . Freire & 3,5 & 0,41 & 1,20 & 4 & 25 & 7,9 & 2,4 & 2,5 & 2,3 & 1,4 & 0,5 & 3,4 & 0,4 & $<0,1$ & $<0,1$ \\
\hline $24 /$ out 94 & 11 - Dr. Vicente & 22 & 0,14 & 19,16 & 20 & 15 & 4,1 & 2,6 & 21,1 & 5,9 & 0,6 & 0,3 & 0,9 & $<0,1$ & $<0,1$ & $<0,1$ \\
\hline $24 /$ out $/ 94$ & 12 - H. Sitva & 19,5 & 0,21 & 18,47 & 10 & 65 & 25 & 5,8 & 17,6 & 5,6 & 2,2 & 0,2 & 2,2 & 0,5 & $<0,1$ & 0,3 \\
\hline $25 /$ out $/ 94$ & 13-EMEI & 10,5 & 0,22 & 18,33 & 3 & 35 & 8,4 & 3,9 & 12,1 & 4 & 2,7 & 0,3 & 4 & 0,8 & $<0,1$ & 0,1 \\
\hline
\end{tabular}

\begin{tabular}{|c|c|c|c|c|c|c|c|c|c|c|c|c|c|c|c|c|}
\hline DATA DA & POÇO & Cl & $F$ (total) & N (Nitrato) & SO4 & $\mathrm{HCO} 3$ & $\mathrm{Ca}$ & $\mathrm{Mg}$ & $\mathrm{Na}$ & $\bar{K}$ & $\mathrm{Fe}$ & Mn & $\mathbf{A l}$ & $2 \mathbf{n}$ & $\mathrm{Cu}$ & $\mathrm{Pb}$ \\
\hline COLETA & & & & & (total) & (CaCO3) & & & & & (total) & & & & & \\
\hline $24 / j a n / 95$ & 01 - Limão & 7,07 & 0,34 & 0,22 & 143,66 & $>400$ & 195 & 124,5 & 10,8 & 44 & 16,8 & 0,2 & 0,14 & 0,03 & $<0,03$ & $<0,05$ \\
\hline 24 jan/95 & 02 - P. Martins & 68,31 & 1,07 & 21,23 & 2,3 & 230 & 11,8 & 3,8 & 68 & 5 & 24,6 & 0,26 & 1,52 & 0,13 & $<0,03$ & $<0,05$ \\
\hline $23 \sqrt{\operatorname{an} / 95}$ & 03 - Fco Matarazo & 24,4 & 0,07 & 41,66 & 0,22 & 45 & 7,5 & 3 & 20 & 2,5 & 0,36 & 0,07 & 0,84 & 0,12 & $<0,03$ & $<0,05$ \\
\hline $23 /$ jan/95 & 04 - Várzea & 1,06 & 0,21 & 0,12 & 4,31 & 50 & 5.4 & 1 & 1,5 & 15,2 & $\overline{1,2}$ & $<0,02$ & 3,5 & 0,05 & $<0,03$ & $<0,05$ \\
\hline $24 / \mathrm{jan} / 95$ & 05 - Cornélia & 12,63 & 0,23 & 1,23 & 0,63 & 90 & 1,2 & 1 & 11,6 & 4,5 & 29,4 & 0,02 & 0,14 & 0,05 & n.d. & n.d. \\
\hline $24 /$ jan/95 & $06-\bar{A}$ Branca & 29,38 & $\overline{0,04}$ & 20,5 & 11,83 & 45 & 7,5 & 3,1 & 25,6 & 8,5 & 0,66 & 0,06 & 3,11 & 0,06 & $<0,03$ & n.d. \\
\hline $23 / \mathrm{jan} / 95$ & 07 - Nacional & 44,5 & 0,24 & 0,12 & 2,17 & 115 & 12,9 & 12 & 34 & 9 & 2,97 & 0,04 & 0,14 & 0,01 & n.d & n.d. \\
\hline 24/jan/95 & 08 - J. Bandeira & 19,26 & 0,07 & 30,77 & 11,97 & 25 & 5,4 & 1,9 & 20,4 & 4,3 & 0,17 & 0,22 & 0,14 & 0,13 & $<0,03$ & 0,18 \\
\hline $23 / \mathrm{jan} / 95$ & $09-1$. Karman & 9,16 & n.d. & 0,63 & 4,99 & 45 & 9,3 & 4,9 & 7,2 & 3,1 & 0,11 & 0,18 & 0,14 & 0,05 & n.d. & n.d. \\
\hline $23 \sqrt{3 a n} / 95$ & $10-0$. Freire & 9,51 & n.d. & 19,24 & 7,1 & 20 & 10,1 & 2,3 & 8 & 2,5 & 0,09 & 0,03 & 0,14 & 0,18 & n.d. & n.d. \\
\hline $24 / \mathrm{jan} / 95$ & 11 - Dr. Vicente & 24,35 & 0,04 & 24,89 & 26,36 & 15 & 4,8 & 3,3 & 26 & 6 & 0,26 & 0,32 & 1,52 & 0,04 & $<0,03$ & $<0,05$ \\
\hline 24 /jan/95 & 12-H. Siva & 17,76 & n.d. & 21,59 & 32,87 & 110 & 35 & 9,4 & 19,2 & 6,2 & $<0,05$ & 0,12 & $\overline{0,14}$ & $\overline{0,09}$ & n.d. & 0,1 \\
\hline 24/jan/95 & 13-EMEI & 16,18 & 0,05 & 49,8 & 0,23 & 20 & 4,8 & 3,5 & 15,6 & 5,4 & 0,28 & 0,08 & 0,38 & 11 & $<0,03$ & n.d. \\
\hline
\end{tabular}

MAX (OMS)

$250 \quad 1,5 \quad 10$

n.d.: não detectado

Nota: Valores em negrito - acima dos limites de potabilidade, segundo a OMS 
continuação - Tabela 2

\begin{tabular}{|c|c|c|c|c|c|c|c|c|c|c|c|c|c|c|c|c|}
\hline DATA DA & POÇO & $\mathrm{Cl}$ & F (total) & $\mathbf{N}$ (Nitrato) & SO4 & $\mathrm{HCO} 3$ & $\mathbf{C a}$ & $\mathrm{Hg}$ & $\mathrm{Na}$ & $K$ & $\mathrm{Fe}$ & $M n$ & Al & $\mathrm{Zn}$ & $\mathrm{Cu}$ & $\mathrm{Pb}$ \\
\hline COLETA & & & & & (total) & (CaCO3) & & & & & (total) & & & & & \\
\hline 24/mai/95 & 01 - Limão & 3,65 & 0,22 & 64,88 & 7,86 & $>500$ & 101 & 147,5 & 20 & 78 & 10,8 & 0,17 & 0,07 & n.d. & $<0,03$ & n.d. \\
\hline $24 /$ mail95 & 02-P. Martins & $\overline{12,58}$ & 0,05 & 2,44 & 10,66 & 340 & 53,2 & 29,8 & 46 & 9,8 & 16,64 & 0,25 & 0,35 & 0,02 & $<0,03$ & n.d. \\
\hline $24 /$ mail95 & 03 - Fco Matarazo & 9,47 & n.d. & 9,85 & 0,21 & 10 & 7,7 & 3,53 & 21,2 & 2,2 & 0,6 & 0,05 & 0,93 & 0,03 & n.d. & n.d. \\
\hline $24 / \mathrm{mai} / 95$ & 04 - Várzea & - & - & $\sim$ & - & - & - & - & - & - & - & - & - & - & - & - \\
\hline $24 / \mathrm{mai} / 95$ & 05 - Comélia & 5,2 & n.d. & 19,71 & 0,78 & 30 & 3,3 & 2,55 & 23,5 & 3,9 & 7,2 & $\overline{0,04}$ & 0,07 & 0,03 & $<0,03$ & n.d. \\
\hline $24 / \mathrm{mai} / 95$ & $06-\bar{A}$ Branca & 4.66 & n.d. & $\overline{7,4}$ & 1,6 & 10 & 7,4 & 2,95 & 27 & 5 & $<0,05$ & 0,03 & 0,07 & n.d. & n.d. & n.d. \\
\hline $24 / \mathrm{mai} / 95$ & 07 - Nacional & 27,15 & n.d. & & 1,07 & 115 & 15,8 & $\overline{13,4}$ & 36 & 11,6 & 22,16 & 0,05 & 0,07 & $<0,02$ & $<0,03$ & n.d. \\
\hline $24 /$ mail95 & 08- J. Bandeira & 5,75 & n.d. & 8,97 & 4,14 & 15 & 7,7 & 2,64 & 23 & 4,8 & 0,52 & 0,29 & 0,07 & n.d. & n.d. & n.d. \\
\hline $24 / \mathrm{ma} / 95$ & $09-1$ Karman & 0,24 & n.d. & 0,09 & 0,19 & 15 & 1,6 & 0,84 & 2 & 1,7 & 0,24 & 0,04 & 0,07 & 0,04 & n.d. & n.d. \\
\hline $24 / \mathrm{mai} / 95$ & $10-0$. Freire & 1,15 & n.d. & 2,09 & 0,71 & 20 & 7,7 & 1,92 & 7,4 & 2 & 0,07 & 0,02 & 0,07 & 0,14 & $<0,03$ & n.d. \\
\hline $24 / \mathrm{mai} / 95$ & $11-\mathrm{Dr}$. Vicente & 3,2 & n.d. & 5,03 & 5,8 & 15 & 5,7 & 3,6 & 26 & 5,7 & 0,14 & 0,36 & 0,93 & n.d. & n.d. & n.d. \\
\hline $24 / \mathrm{mai} / 95$ & $12-$ H. Silva & 12,94 & n.d. & 14,68 & 18,92 & 35 & 25,3 & 9,8 & 26 & 7,7 & 0,23 & 0,08 & 0,07 & $<0,02$ & n.d. & n.d. \\
\hline $24 /$ mai/95 & 13 - EMEI & 4,78 & n.d. & 12,18 & 0,12 & 5 & 5,2 & 3,45 & 18,4 & 5 & 0,13 & 0,07 & 0,35 & $<0,02$ & n.d. & n.d. \\
\hline
\end{tabular}

\begin{tabular}{|c|c|c|c|c|c|c|c|c|c|c|c|c|c|c|c|c|}
\hline DATA DA & POÇO & $\mathrm{Cl}$ & $F$ (total) & $\mathbf{N}$ (Nitrato) & SO4 & $\mathrm{HCO} 3$ & $\mathrm{Ca}$ & $\mathrm{Mg}$ & $\mathrm{Na}$ & $\mathbf{K}$ & $\mathrm{Fe}$ & $M n$ & Al & Zn & $\mathrm{Cu}$ & $\mathrm{Pb}$ \\
\hline COLETA & & & & & (total) & $(\mathrm{CaCO})$ & & & & & (total) & & & & & \\
\hline $21 /$ set/95 & 01 - Limåo & 9,44 & 0,44 & 0,32 & 2,61 & - & 49,2 & 62,4 & 35 & 100 & 0,39 & 0,11 & 0,41 & 0,05 & 0,03 & $<0,05$ \\
\hline 21/set/95 & 02 - P. Martins & - & - & - & - & - & - & - & - & - & - & - & - & - & - & - \\
\hline $21 / \mathrm{set} / 95$ & 03 - Fco Matarazo & 17,52 & n.d. & 31,28 & 0,73 & - & 5,95 & 2,5 & 29 & $\overline{3,3}$ & 2,31 & 0,06 & 1,28 & 0,05 & n.d. & n.d. \\
\hline $21 / \mathrm{set} / 95$ & 04 -Várzea & - & - & - & - & - & - & - & + & - & - & - & - & - & - & - \\
\hline $21 /$ set/95 & 05-Comélia & 10,89 & n.d. & 0,45 & 0,94 & $\overline{-}$ & 1,3 & 1,95 & 11,2 & 7,2 & 38,7 & 0,04 & 5,72 & 0,13 & 0,05 & 0,22 \\
\hline $21 /$ set/95 & $06-A \cdot$ Branca & 26,4 & n.d. & 41,9 & 6,13 & - & 7,45 & 3,25 & 46 & 5,1 & 0,1 & 0,02 & $<0,05$ & $\overline{0,03}$ & n.d. & $<0,05$ \\
\hline $21 / \mathrm{set} / 95$ & 07 - Nacional & 41,62 & n.d. & 0,55 & 3,58 & - & 13,55 & 14,9 & 34 & 12 & 8,21 & 0,05 & $<0,05$ & 0,02 & n.d. & $<0,05$ \\
\hline $21 /$ set 95 & 08 - J. Bandeira & 19,39 & n.d. & 32,26 & 12,88 & $\overline{-}$ & 6,85 & 2,3 & 21 & 4,5 & 0,26 & 0,24 & $<0,05$ & 0,03 & n.d. & n.d. \\
\hline $21 /$ set/95 & $09-1$. Karman & 3,32 & n.d. & 1,64 & 2,6 & - & 1,75 & 0,95 & 2,5 & 2 & 1,86 & 0,05 & $<0,05$ & 0,06 & n.d. & $<0,05$ \\
\hline $21 / \mathrm{set} / 95$ & 10 - 0 . Freire & 6,27 & n.d. & 14,45 & 26,29 & - & 4,1 & 1,45 & 5,8 & 1,5 & n.d. & 0,03 & n.d. & 0,14 & n.d. & $<0,05$ \\
\hline $21 / \mathrm{set} / 95$ & 11 - Dr. Vicente & - & & - & - & $=$ & 6,25 & 4,25 & 25,5 & 6,2 & 0,85 & 0,39 & & 0,05 & n.d. & n.d. \\
\hline $21 / \operatorname{set} / 95$ & 12 - H. Silva & 19,48 & n.d. & 7,48 & 17,57 & - & 20,9 & 7,6 & 22,5 & 6,5 & 0,33 & 0,09 & $<0,05$ & 0,03 & n.d. & n.d. \\
\hline $21 / \mathrm{set} / 95$ & 13-EMEI & 18,45 & n.d. & 59,55 & 2,84 & - & 4,7 & 3,5 & 23,5 & 5,6 & 2,63 & 0,06 & 3,09 & 0,1 & $<0,03$ & 0,06 \\
\hline & & 250 & 1,5 & 10 & 400 & & 75 & 125 & 200 & - & 0,3 & 0,1 & 0,2 & 5 & 1 & 0,05 \\
\hline
\end{tabular}

\begin{tabular}{|l|c|c|c}
\hline MAX.OMS) & 250 & 1,5 & 10 \\
\hline
\end{tabular}

n.d. não detectado 
Tabela 3 - Resultados das análises químicas nas Nascentes

\begin{tabular}{|c|c|c|c|c|c|c|c|c|c|c|c|c|c|c|c|c|}
\hline DATA DA & NASCENTE & $\mathrm{Cl}$ & $F$ & $\mathbf{N}$ & 504 & $\mathrm{HCO} 3$ & $\mathrm{Ca}$ & $\mathrm{Mg}$ & $\mathrm{Na}$ & K & $\mathrm{Fe}$ & $M n$ & Al & $\mathrm{Zn}$ & $\mathrm{Cu}$ & $\mathrm{Pb}$ \\
\hline COLETA & & & (total) & Nitrato & (total) & (CaCO3) & & & & & (total) & & & & & \\
\hline & & & & & & & & & & & & & & & & \\
\hline $22 / \mathrm{set} / 94$ & 6- J. Paulo V & 8,5 & 0,15 & 0,26 & 2 & 130 & 12,60 & 1,1 & 6,3 & 5,7 & 0,1 & N.D. & 0,3 & n.d. & n.d. & n.d. \\
\hline $22 /$ set/94 & 3-M. Godoy & 12,5 & $\overline{0,18}$ & 4,40 & 2 & 40 & 3,10 & 1,7 & 5,3 & $\overline{4,4}$ & $\overline{0,3}$ & N.D. & 0,3 & n.d. & n.d. & n.d. \\
\hline $22 /$ set/94 & 5-Cajaíba & 20,0 & 0,17 & 12,00 & 2 & 40 & 5,80 & 3,1 & 22 & 4,1 & n.d. & 0,2 & 1,2 & n.d. & n.d. & n.d. \\
\hline $22 / \mathrm{set} / 94$ & 4 - Paulo Vieira & 14,0 & 0,17 & 7,60 & 5 & 40 & 3,50 & 1,4 & 14,6 & $\overline{3,2}$ & n.d. & 0,1 & $\overline{0,6}$ & n.d. & n.d. & n.d. \\
\hline 10/out/94 & 7-Água Branca & 12,0 & $<0,1$ & 4,37 & 6 & 76 & 10,60 & 2,7 & 20,6 & 3,5 & 0,6 & 0,1 & 0,2 & n.d. & n.d. & n.d. \\
\hline $22 /$ set/94 & SABESP & 3,00 & 0,81 & 0,12 & 3 & $\overline{-}$ & 5,50 & 1,2 & 2,3 & 2 & 0,1 & N.D. & 0,2 & n.d. & n.d. & n.d. \\
\hline
\end{tabular}

$22 /$ set/94

\begin{tabular}{|l|l|l|l|l}
\hline $24 / j a n / 95$ & 7 -Agua Branca & 19,09 & 0,04 & $\mathbf{4 6 , 3 6}$ \\
\hline
\end{tabular}

\begin{tabular}{|c|c|c|c|c|c|c|c|c|c|c|c|c|c|c|c|c|}
\hline DATADA & NASCENTE & $\mathrm{Cl}$ & $\frac{F}{\text { (total) }}$ & Nitrato & (total) & (CaCO3) & & & & & (total) & & & & & \\
\hline COLETA & & & & 0,81 & 1,37 & 40 & 12,8 & 1,24 & 7,6 & 1,8 & 0,2 & $<0,02$ & n.d. & n.d. & n.d. & n.d. \\
\hline $24 /$ mai/95 & 6 - Joåo Paulo V & 4 & 0,1 & 21,61 & 8,54 & 20 & 8,7 & 5,48 & 16 & 6 & n.d. & 0,16 & 0,07 & $<0,02$ & n.d. & n.d. \\
\hline $24 /$ mail95 & 1-Sumaré & 11,14 & 0,1 & 36,1 & 4,05 & 15 & 7,3 & 3,6 & 28 & $\overline{3,8}$ & $<0,05$ & 0,25 & 0,93 & n.d. & n.d. & n.d. \\
\hline $24 / \mathrm{mai} / 95$ & 5-Cajaíba & 12,03 & $\frac{0}{\text { n.d. }}$ & 15,79 & 5,1 & 15 & 5,2 & 1,8 & 16 & 3,6 & n.d. & 0,19 & 0,35 & 0,02 & n.d. & n.d. \\
\hline 24/mai/95 & 4 - Paulo Vieira & 9,3 & $\frac{\text { n.d. }}{\text { n.d. }}$ & 21,71 & 2,86 & 10 & 5,8 & 1,72 & 25 & 3 & $<0,05$ & 0,03 & n.d. & $<0,02$ & n.d. & n.d. \\
\hline $24 /$ mail95 & 7 - Agua Branca & 9,86 & n.d. & & & & & & & & & & & & & \\
\hline
\end{tabular}

4-Paulo Vieira

\begin{tabular}{l|l|l|l|l}
\hline & - Agua Branca & 9,86 & n.d. \\
\hline
\end{tabular}

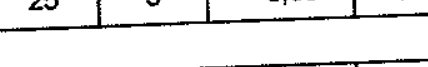

\begin{tabular}{|c|c|c|c|c|c|c|c|c|c|c|c|c|c|c|c|c|}
\hline 24/mai/95 & 7 - Agua Branca & 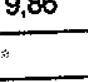 & & & & & & & & & $\mathrm{Fe}$ & $M n$ & Al & $\mathrm{Zn}$ & $\mathrm{Cu}$ & $\mathbf{P b}$ \\
\hline DATA DA & NASCENTE & $\mathrm{Cl}$ & $\mathbf{F}$ & $\mathbf{N}$ & SO4 & $\mathrm{HCO} 3$ & $\mathrm{Ca}$ & $\mathrm{Mg}$ & $\mathrm{Na}$ & $\mathbf{K}$ & (total) & & & & & \\
\hline COLETA & & & (total) & Nitrato & (total) & $(\mathrm{CaCO})$ & & & - & - & - & - & - & - & - & - \\
\hline $21 / \mathrm{set} / 95$ & 6 - Još Paulo V & - & - & - & - & - & - & $\frac{-}{5,1}$ & 16 & 5,9 & n.d. & 0,15 & $<0,05$ & $\overline{0,02}$ & n.d. & n.d. \\
\hline $21 /$ set/95 & 1- Sumaré & 16,86 & 0,2 & 31,97 & 11,37 & - & 7,05 & 5,1 & $\overline{30,5}$ & 3,8 & $<0,05$ & 0,21 & 0,07 & 0,02 & n.d. & $<0,05$ \\
\hline $21 / \mathrm{set} / 95$ & 5 - Cajaíba & 11,71 & n.d. & 33,94 & 3,88 & - & 5,85 & $\frac{2,7}{1,25}$ & $\overline{15,5}$ & $\overline{3,2}$ & n.d. & 0,15 & $<0,05$ & n.d. & n.d. & n.d. \\
\hline $21 /$ set/95 & 4-Paulo Vieira & 10,41 & n.d. & 19,4 & 5,93 & - & $\frac{3,6}{4,75}$ & $\frac{1,25}{1,5}$ & $\overline{26,5}$ & 3,5 & 0,13 & $\overline{0,02}$ & 20,05 & 0,02 & n.d. & n.d. \\
\hline $21 /$ set/95 & 7 -Agua Branca & 36,27 & n.d. & 31,7 & 10,44 & - & & ando & & & & & & & & \\
\hline
\end{tabular}

\begin{tabular}{|l|l|l|l} 
21/set/95 & 7 - Agua Branca & 36,27 & n.d. \\
\hline
\end{tabular} 